
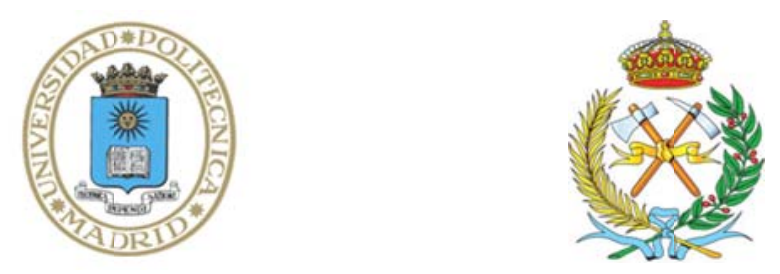

Reducción de la incertidumbre de los modelos de distribución de especies con datos ecológicos y paleoecológicos

TESIS DOCTORAL

Elena Moreno Amat

Ingeniera de Montes

2016 

PROGRAMA DE DOCTORADO EN INVESTIGACIÓN FORESTAL AVANZADA

ESCUELA TÉCNICA SUPERIOR DE INGENIEROS DE MONTES
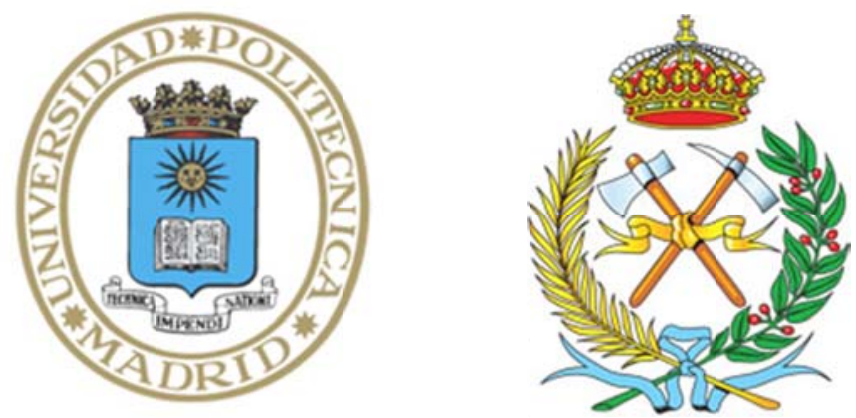

Reducción de la incertidumbre de los modelos de distribución de especies con datos ecológicos y paleoecológicos

Elena Moreno Amat Ingeniera de Montes

Director:

Ignacio García-Amorena Gómez del Moral

Doctor Ingeniero de Montes 



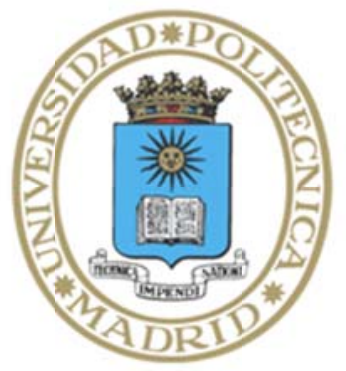

Universidad Politécnica de Madrid

Tribunal nombrado por el Magfco. y Excmo. Sr. Rector de la Universidad Politécnica de Madrid, el día. de. .de $20 \ldots$.

Presidente:

Vocal:

Vocal:

Vocal:

Secretario:

Suplente:

Suplente:

Realizado el acto de defensa y lectura de la Tesis el día.......de. de $20 \ldots$. en la E.T.S.I./Facultad.

EL PRESIDENTE

LOS VOCALES

EL SECRETARIO 



\section{MENCIÓN DE DOCTORADO INTERNACIONAL INTERNATIONAL DOCTORATE MENTION}

Esta tesis ha sido informada positivamente para su defensa en exposición pública por los siguientes investigadores:

This Ph.D. Thesis has been positively evaluated for its public defense by the following external reviewers:

Dr. Sara Varela

Museum für Naturkunde (Berlin, Germany)

Professor Jens-Christian Svenning

Ecoinformatics \& Biodiversity, Department of Bioscience

Aarhus University (Aarhus, Denmark) 



\section{AGRADECIMIENTOS}

Esta tesis doctoral ha sido financiada con una beca-contrato predoctoral de la Universidad Politécnica de Madrid (UPM-RR01/2011), los proyectos de investigación CLIMIFORAD del Banco Interamericano de Desarrollo (RG-T1837) y DIPAVE del Ministerio de Economía y Competitividad (CSO2015-65216-C2-2-P). A la UPM le agradezco también su apoyo económico durante las estancias en el extranjero.

A la Universidad de Aarhus le debo el apoyo económico durante mi primera estancia en Dinamarca (Visiting Grant from Graduate School Science and Technology - Aarhus University, Denmark).

A la persona a la que debo agradecer primero es Ignacio García-Amorena, por abrir la línea de investigación de modelización en el grupo "Historia y dinámica del paisaje vegetal de la Península Ibérica" y ofrecerme la posibilidad de realizar esta tesis. Nacho me inició en el mundillo de la paleobotánica en el 2007 y le agradezco especialmente su energía y dedicación para enseñarme a trabajar en el entorno científico. Además le quiero agradecer su paciencia y apoyo continuo.

Otra pata importante de esta tesis ha sido el equipo de la Unidad Docente de Botánica y del grupo de investigación "Historia y Dinámica del Paisaje Natural de la Península Ibérica". A ellos les agradezco profundamente su apoyo moral, además del económico, que fue imprescindible para la asistencia a congresos nacionales e internacionales. Cada miembro del grupo (Nacho, Fernando, Carlos, Juanma, Felipe, Paloma, Merce, Mar y Jose), a su manera, me ha transmitido y ayudado enormemente, especialmente el equipazo de becarios con los que me solapé durante un tiempo, el llamado gallinero (Juanma, Salvia, César y Laura).

A mis coautores (Rubén, Diego, Naia, Jens, Juanma, César, Blas y Nacho) por su inestimable ayuda, orientación y dedicación a los manuscritos. Asimismo quisiera agradecer a los editores y los revisores anónimos por sus comentarios y sugerencias que sin duda ayudaron a mejorar los artículos.

Gracias también a los autores que me facilitaron los datos de porcentajes polínicos de sus yacimientos y me permitieron obtener los resultados del tercer capítulo con mayor precisión: César Morales del Molino, Lourdes López Merino, María Fernanda Sánchez Goñi, José Antonio López Sáez, Francesc Burjachs Casas, Miriam Dorado Valiño, Tony Stevenson y Penélope González Sampériz. Además me gustaría agradecer a todos los autores que ponen 
sus datos en bases de datos libres y gratuitas (GBIF, European Pollen Database, Neotoma, Paleobiology Database, Paleodiversitas, etc.) para que puedan ser usados por otros autores, facilitando la investigación y el avance de la ciencia. Especialmente le agradezco a Aljos Farjon y al departamento de Plant Sciences (Universidad de Oxford) por la publicación online de la base de datos Conifers of the World y a los organismos responsables de la publicación de los inventarios forestales nacionales español (IFN3, 2008) y francés (IGN, 2013).

Asimismo, agradezco al grupo de trabajo del World Climate Research Programme responsable del quinto Coupled Model Intercomparison Project (CMIP5) y a todos los grupos de modelos climáticos por producir y hacer disponibles los resultados de sus modelos, y a los autores de la base de datos de WORLCLIM por hacer fácilmente accesibles los datos climáticos para el presente, pasado y futuro.

A la Agencia Española de Meteorología (AEMET) por los datos climáticos observados de las estaciones meteorológicas y a la Fundación para la Investigación del Clima (FIC) y especialmente a Jaime Ribalaygua y Javier Pórtoles por su ayuda para entender los modelos climáticos y hacer el downscaling de los datos en el presente y en los escenarios futuros para la Península Ibérica. Este downscaling se realizó a través del proyecto ("Scientific research for the adaptation of Pinus pinaster Ait. and Pinus halepensis Mill. to climate change") financiado por el Ministerio de Agricultura, Alimentación y Medio Ambiente (MAGRAMA). Finalmente agradezco a María Jesús Serra y los diferentes grupos participantes en ese proyecto por permitirme usar estos datos climáticos.

A los compañeros de la Universidad de Aarhus por hacerme tan productivas y felices las estancias de investigación y especialmente a Jens-Christian Svenning por su acogida en el grupo de investigación Ecoinformatics and Biodiversity y por su valiosas aportaciones a mis ideas y borradores.

A Menci por ser tan buena compañera y amiga en el proyecto CLIMIFORAD y por hacer el mapa de vegetación a partir de la imagen de satélite que ha permitido el trabajo del capítulo 5.

A Iciar Alberdi por su impagable ayuda con los datos del inventario forestal en los inicios de mi investigación y por resolver siempre las dudas que me surgían por el camino.

A Salvia García Álvarez por colaborar en la recopilación y homogeneización de los datos fósiles de la Península Ibérica y los buenos ratos juntas. 
A Ángela García de Arana por ayudarme con el inglés tan desprendidamente a pesar de avisarla de forma intempestiva.

A Vanesa Martínez por sus consejos y su ayuda con el código de $\mathrm{R}$ y por revisar el borrador, y a Rob Muscarella por su asistencia para generar los modelos a través del paquete "ENMeval" del capítulo 4.

A Sonia Roig por su energía contagiosa y sus ánimos en el duro final de la tesis, y a Almudena Izquierdo por su ayuda y apoyo en los pesados trámites y papeleos de la tesis.

A Agresta S. Coop. por el asesoramiento en Gis y por dejarme usar su oficina, impresora y wi-fi cuando la escuela cerraba.

A mis compañeros becarios y no becarios que han acompañado cafés, charlas, alegrías y desvelos a lo largo de esta tesis.

A mis amigos/as de toda la vida, de teatro y de Montes, les debo los ánimos y las ganas de seguir adelante.

A mi familia por su apoyo constante en alegrías y agobios. Especialmente a Pancra, por su energía continua y a Tomás, por ser un ejemplo de esfuerzo y constancia y por acompañarme en todos los jaleos.

Y agradezco también sinceramente a todas aquellas personas que, de un modo u otro, han puesto su granito de arena en estos años para ayudarme a realizar esta tesis, aunque no aparezcan aquí nombrados. 
Cultivemos la ciencia por sí misma, sin considerar por el momento las aplicaciones. Estas llegan siempre, a veces tardan años, a veces, siglos.

Santiago Ramón y Cajal

Essentially, all models are wrong, but some are useful. George Box 


\section{ÍNDICE}

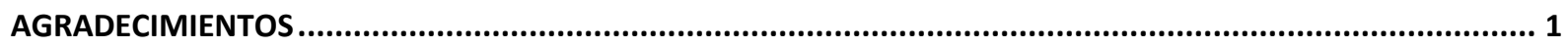

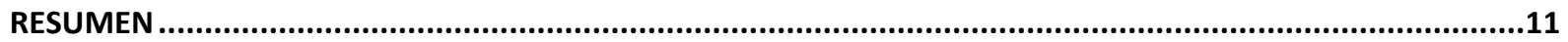

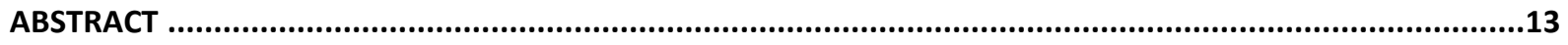

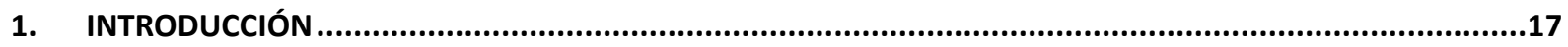

1.1 LIMITACIONES DE LOS MODELOS DE DISTRIBUCIÓN DE ESPECIES .....................................................19

1.2 INTERPRETACIÓN DE LOS MODELOS DE DISTRIBUCIÓN DE ESPECIES. ¿QUÉ ESTAMOS MODELIZANDO? ...20

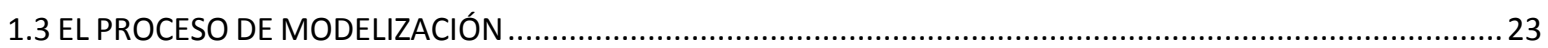

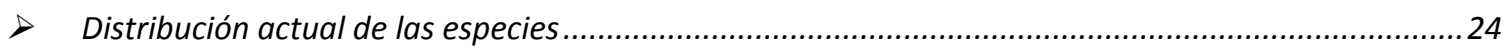

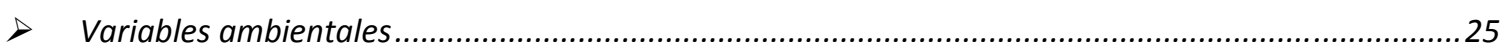

> Selección de las variables ambientales ...........................................................................................26

$>$ Elección del algoritmo de modelización. ........................................................................................26

> Calibración de los modelos de distribución de especies .......................................................................28

> Validación de los modelos de distribución de especies ....................................................................30

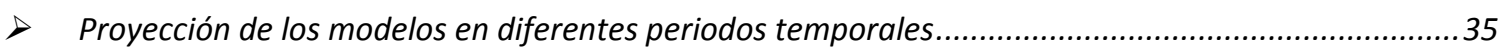

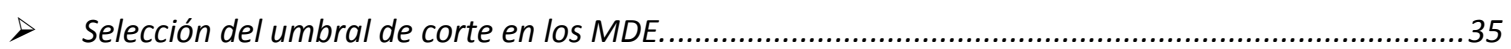

1.4 EL USO DE LA INFORMACIÓN PALEOBOTÁNICA EN LOS MODELOS DE DISTRIBUCIÓN DE ESPECIES............36

1.5 INFLUENCIA DE LA COMPLEJIDAD DE LOS MODELOS DE DISTRIBUCIÓN DE ESPECIES EN SU

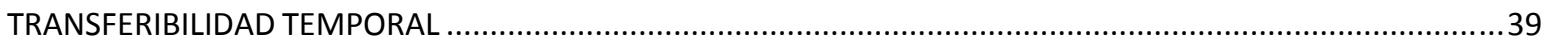

1.6 INFLUENCIA DE LOS DATOS DE ENTRADA (DATOS DE PRESENCIA Y DATOS CLIMÁTICOS) EN EL PROCESO DE MODELIZACIÓN Y EN LAS PREDICCIONES FUTURAS DE LOS MODELOS. ....................................................41

1.7 EL USO DE LA IMÁGENES DE SATÉLITE EN LOS MODELOS DE DISTRIBUCIÓN DE ESPECIES ..........................42

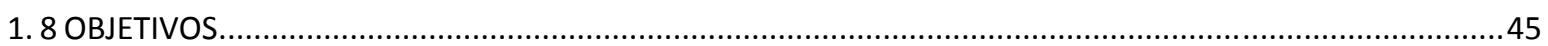

2. POTENCIAL Y LIMITACIONES DEL USO DE DATOS PALEOBOTÁNICOS EN TRABAJOS DE MODELOS DE

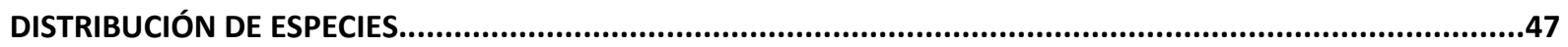

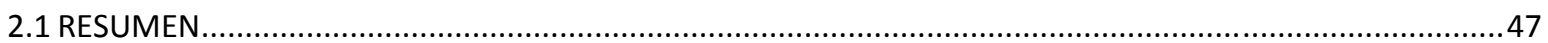

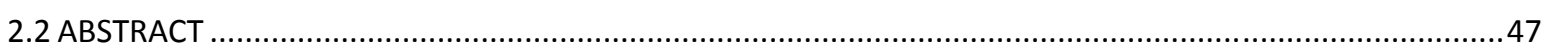

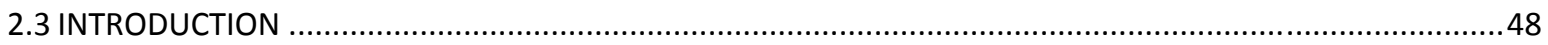

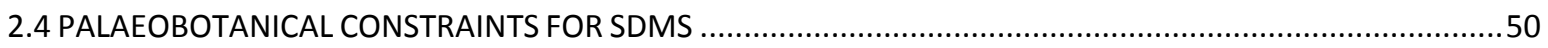

2.5 USE OF QUATERNARY PALAEOBOTANICAL DATA IN SPECIES DISTRIBUTION MODEL STUDIES..................61

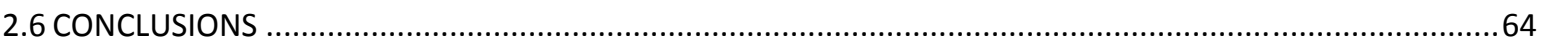

\section{INFLUENCIA DE LA COMPLEJIDAD DE LOS MODELOS Y DEL TIPO DE VALIDACIÓN CON DATOS} PALEOBOTÁNICOS EN EL PROCESO DE MODELIZACIÓN Y EN LA TRANSFERIBILIDAD TEMPORAL DE LOS MODELOS.

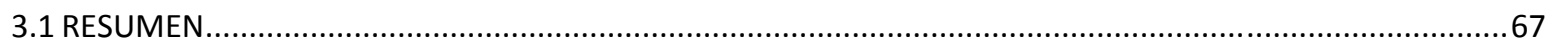

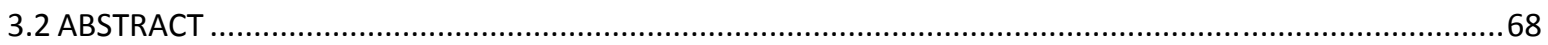

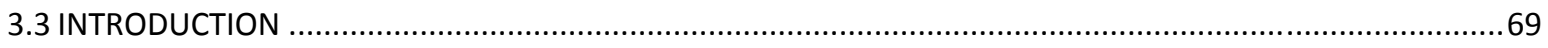

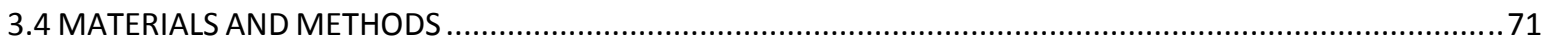

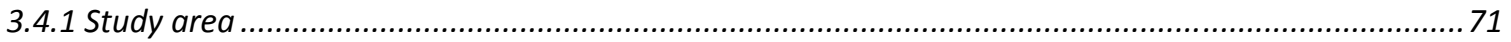

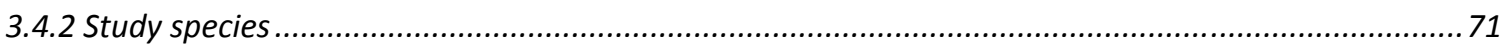

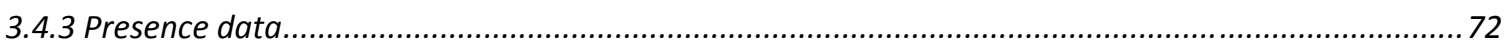

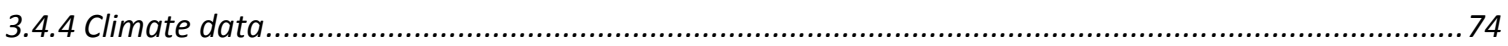

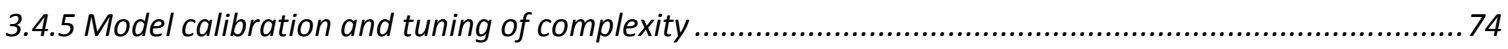

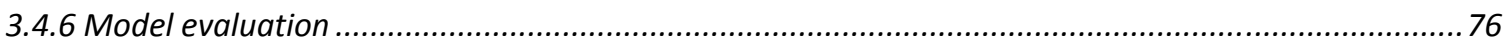

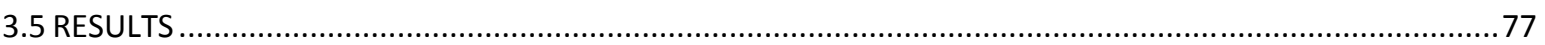




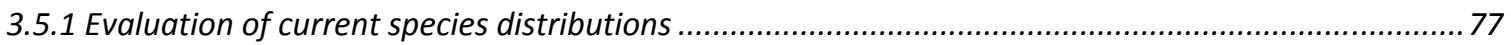

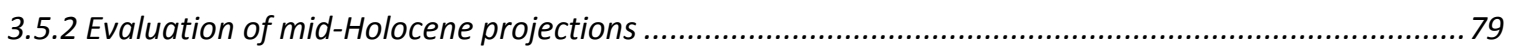

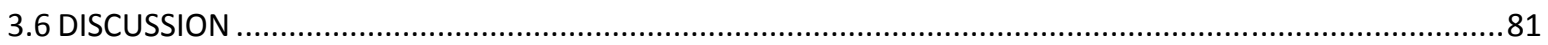

3.6.1 Effects of complexity in current and past species distributions..........................................................82

3.6.2 How do Maxent settings affect model complexity? .........................................................................83

3.6.3 The importance of species-specific tuning in Maxent models.............................................................. 84

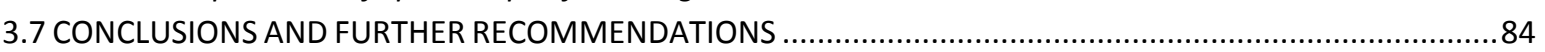

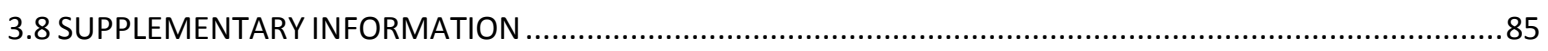

4. INFLUENCIA DE LAS POBLACIONES MARGINALES Y DEL USO DE DISTINTAS BASES DE DATOS CLIMÁTICAS EN EL PROCESO DE MODELIZACIÓN, EN LA TRANSFERIBILIDAD ESPACIAL Y EN LAS PREDICCIONES FUTURAS DE LOS MODELOS EN EL ESTUDIO DEL IMPACTO DEL CAMBIO CLIMÁTICO ..............................................103

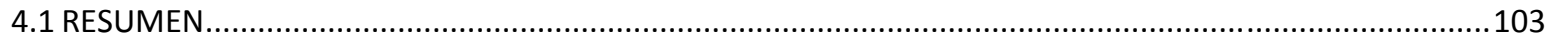

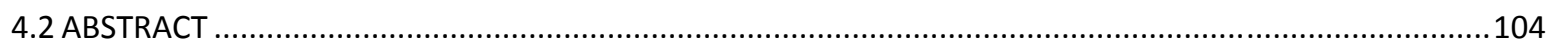

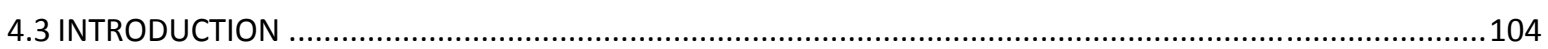

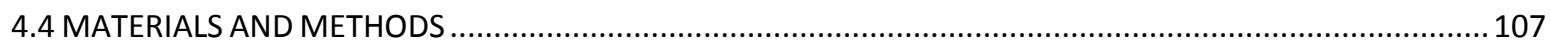

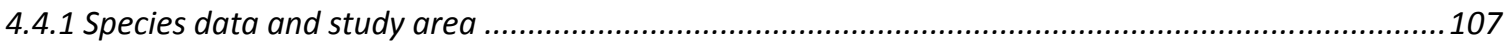

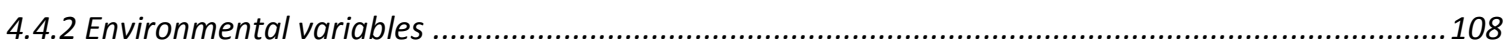

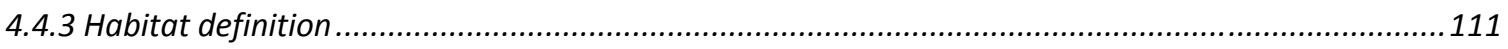

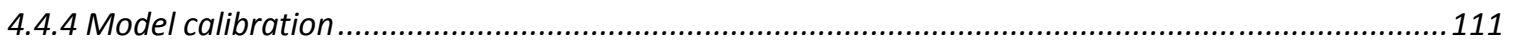

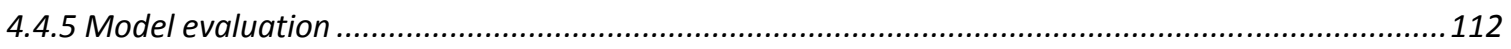

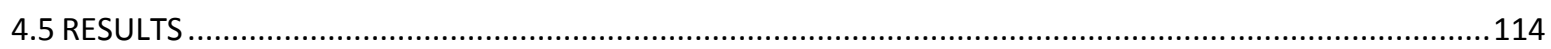

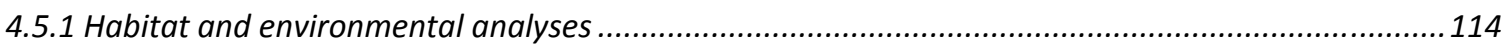

4.5.2 Evaluation of current P. uncinata models ....................................................................................... 116

$>\quad$ Differences between AICC and default selected models.................................................................116

$>\quad$ Differences between climatic databases............................................................................................. 116

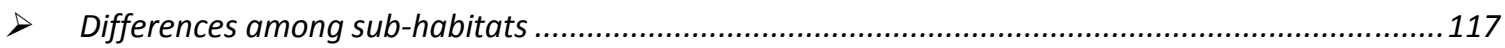

$>\quad$ Evaluation of current spatial predictions ................................................................................ 118

4.5.3 Evaluation of species future projections ............................................................................... 120

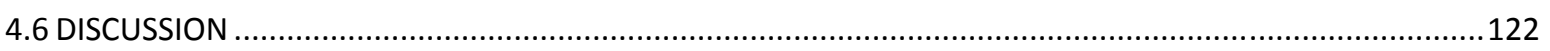

4.6.1 Effect of species-specific tuning in Maxent models..................................................................... 122

4.6.2 How do data from different climatic databases affect model predictions?.....................................122

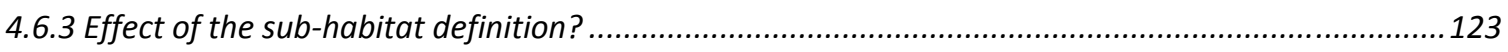

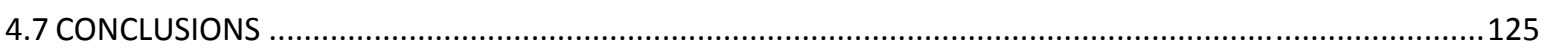

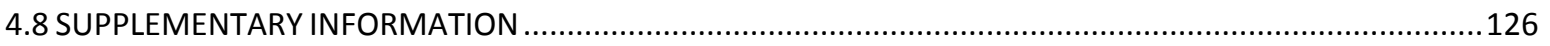

5. VALIDACIÓN DE MODELOS DE DISTRIBUCIÓN DE ESPECIES CON IMÁGENES DE SATÉLITE. APLICACIÓN EN EL ESTUDIO DE LA VULNERABILIDAD FUTURA DE PINUS HARTWEGII LINDL. EN EL PARQUE NACIONAL IZTA -

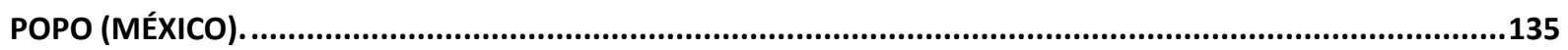

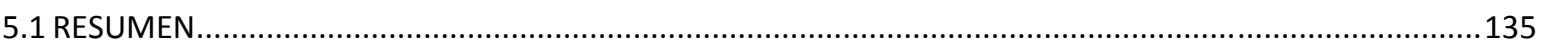

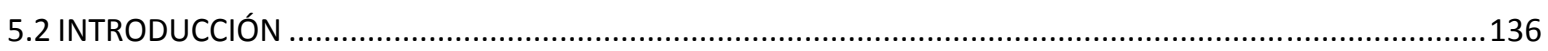

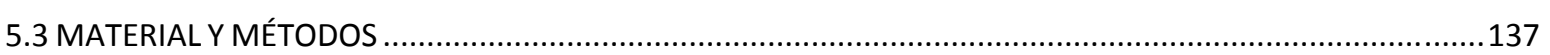

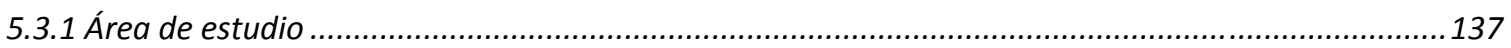

5.3.2 Especie de estudio y datos de presencias..................................................................................... 138

5.3.3 Variables ambientales (presente y futuro) ................................................................................. 141

5.3.4 Calibración de los modelos (selección de diferentes niveles de complejidad)...................................142

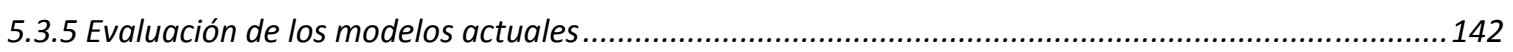

5.3.6 Validación de los modelos con imágenes de satélite .....................................................................142

5.3.7 Proyección de los modelos bajo escenarios futuros de cambio climático .........................................145

5.3.8 Evaluación de la sensibilidad de las especies ............................................................................146 
5.3.9 Cálculo y evaluación de los índices de sensibilidad

5.4.1 Modelos de distribución de especie proyectados a presente y validación con imágenes satélite.148

5.4.2 Modelos de distribución de especie proyectados a futuro............................................................150

5.4.3 Evaluación de índices de sensibilidad y vulnerabilidad futura ......................................................153

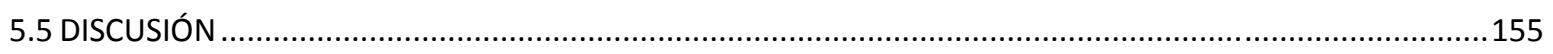

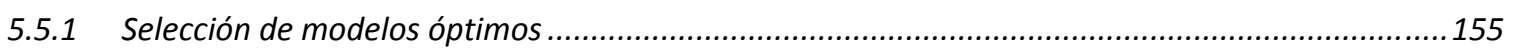

5.5.2 Utilidad de las imágenes de satélite en modelos de distribución de especies ...............................156

5.5.3 ¿Cómo afectan los umbrales a las predicciones de los modelos? .................................................157

5.5.4 Efectos del cambio climático en la distribución de Pinus hartwegii en el parque nacional Izta-Popo 158

6. DISCUSIÓN. .161

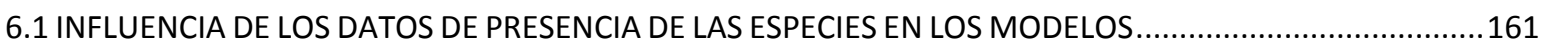

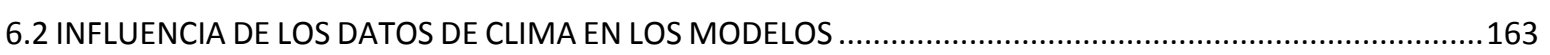

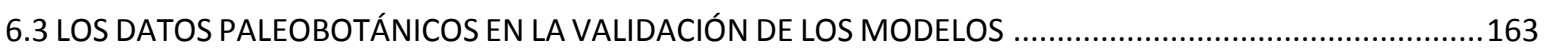

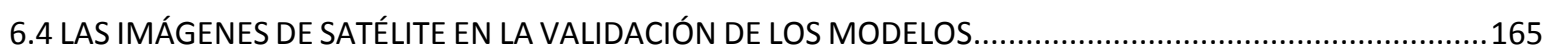

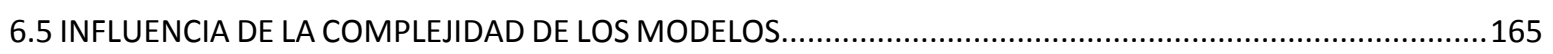

6.6 SELECCIÓN DE LOS PARÁMETROS ÓPTIMOS DE COMPLEJIDAD EN MAXENT.........................................166

6.7 INFLUENCIA DE LA SELECCIÓN DEL UMBRAL DE LOS MODELOS ......................................................166

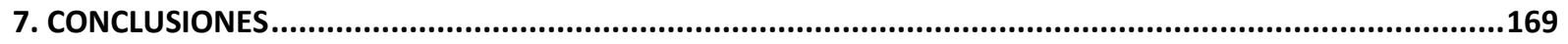

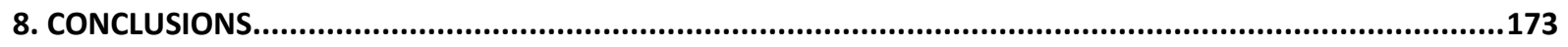

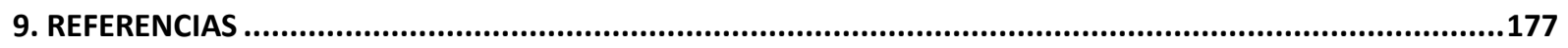

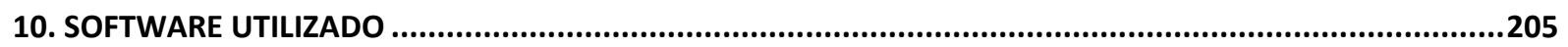

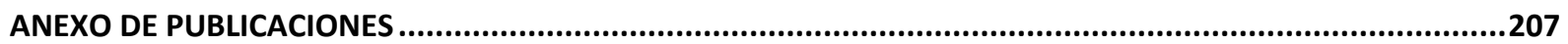




\section{RESUMEN}

A pesar del amplio uso de los Modelos de Distribución de Especies (MDE: algoritmos que establecen relaciones estadísticas entre las presencias de una especie y las variables ambientales) en el estudio de la distribución actual de los taxones y el impacto derivado del cambio climático, su aplicabilidad y la validez de sus predicciones es todavía objeto de estudio. Esta tesis trata de reducir la incertidumbre de los MDE para mejorar su transferibilidad temporal y espacial mediante la incorporación de la información aportada por la paleobotánica, por las imágenes de satélite y el estudio de la influencia de diferentes factores en el proceso de modelización. En primer lugar se revisa el potencial y las limitaciones del uso de los datos fósiles en los MDE y se proponen recomendaciones teniendo en cuenta las características de los datos paleobotánicos en cuanto a representatividad, taxonomía y cronología (Capítulo 2). Asimismo, se estudia la influencia de la complejidad de los modelos en la capacidad predictiva de los mismos y en su transferibilidad temporal mediante su proyección en el Holoceno Medio y su validación con datos paleobotánicos (Capítulo 3). Posteriormente se evalúa el efecto de los datos de entrada (división de los datos de presencia según sub-hábitats y bases de datos climáticas) en las predicciones de los modelos sobre poblaciones marginales y su aplicación en el estudio del impacto del cambio climático (Capítulo 4). Por último se valida la capacidad predictiva de los MDE con imágenes de satélite, evaluando la influencia de las presencias y umbrales usados en el modelo y su uso en el estudio de la sensibilidad de especies frente al cambio climático (Capítulo 5).

Los resultados obtenidos en esta tesis doctoral indican que los parámetros estudiados afectan de forma importante a la capacidad predictiva y a la idoneidad predicha por los modelos, influyendo en la precisión y exactitud de los mismos. Por tanto, deben tenerse en cuenta a la hora de proyectar los modelos hacia diferentes periodos temporales y especialmente bajo escenarios futuros de cambio climático. Además, se recomienda el uso de datos independientes (datos paleobotánicos o imágenes de satélite) para la validación de los modelos y la selección de los parámetros de modelización que mejor funcionen para cada estudio y especie.

Palabras clave: modelos de distribución de especies, Maxent, validación, calibración, complejidad, transferibilidad temporal, distribución geográfica, informadores paleobotánicos, polen fósil, macrofósiles vegetales, proyección al pasado, Trayectorias de Concentración Representativa, modelo de circulación general, sobreajuste, sub-hábitat, umbral, Corylus 
avellana, Alnus glutinosa, Pinus uncinata, Península Ibérica, Pinus hartwegii, imágenes de satélite, México. 


\section{ABSTRACT}

Despite the widespread use of species distribution models (SDM: algorithms that statistically relate the presence of a species and environmental variables) in the study of the present distribution of species and the impact from climate change, its applicability and the validity of their predictions is still under study. This thesis aims to reduce the uncertainty of the SDM in order to improve their temporal and spatial transferability, by incorporating the information provided by the paleobotanical data, satellite imagery and the study of the influence of different factors in the modelling process. First the potential and limitations of using fossil data in the SDMs are reviewed and several recommendations are suggested to consider the characteristics of paleobotanical data regarding representation, taxonomy and chronology in SDM-studies (Chapter 2). Also, the influence of model complexity in their predictive ability and temporal transferability is studied by projecting the SDM to midHolocene climatic conditions and its validation with paleobotanical data (Chapter 3). Subsequently, some analyses are conducted to evaluate the effect of the input data (splitting presence data into sub-habitats and using different climate databases) in models' predictions on marginal populations and their application in the study of climate change impacts (Chapter 4). Finally the influence of the presence and thresholds used in the model and its use in the study of species sensitivity to climate change is assessed by validating SDM predictions with satellite imagery (Chapter 5).

The results obtained in this thesis show that the studied parameters significantly affect model performance and predicted suitability, influencing the precision and accuracy of the models. Therefore these parameters must be carefully considered when projecting models to time periods different than the calibration period and especially under future climate change scenarios. In addition, the use of independent data (paleobotanical data or satellite imagery) for the validation of the SDMs is recommended, as well as the selection of the optimal modeling parameters for each species and study area.

Key-words: species distribution models, Maxent, validation, calibration, complexity, temporal transferability, geographical distribution, paleobotanical proxies, fossil pollen, plant macrofossil, hindcasting, Representative Concentration Pathways, general circulation model, overfitting, sub-habitat, threshold, Corylus avellana, Alnus glutinosa, Pinus uncinata, Iberian Peninsula, Pinus hartwegii, satellite imagery, Mexico. 


\section{Abreviaturas usadas en inglés y español}

\begin{tabular}{|c|c|c|c|}
\hline $\begin{array}{l}\text { Abreviatura } \\
\text { inglés }\end{array}$ & Descripción inglés & $\begin{array}{l}\text { Abreviatura } \\
\text { español }\end{array}$ & Descripción español \\
\hline AIC & $\begin{array}{l}\text { Akaike Information } \\
\text { Criterion }\end{array}$ & & $\begin{array}{c}\text { Criterio de información de } \\
\text { Akaike }\end{array}$ \\
\hline $\mathrm{AICc}$ & $\begin{array}{l}\text { Corrected Akaike } \\
\text { Information Criterion }\end{array}$ & & $\begin{array}{l}\text { Criterio de información de } \\
\text { Akaike corregido }\end{array}$ \\
\hline AOGCM & $\begin{array}{c}\text { Atmosphere-Ocean } \\
\text { General Circulation } \\
\text { Model }\end{array}$ & MCGAO & $\begin{array}{l}\text { Modelo de circulación general } \\
\text { atmosférico-oceánico }\end{array}$ \\
\hline AUC & $\begin{array}{l}\text { Area under the ROC } \\
\text { curve }\end{array}$ & & Area bajo la curva ROC \\
\hline BP & Before present & & Antes del presente \\
\hline GCM & $\begin{array}{l}\text { General circulation } \\
\text { model }\end{array}$ & MCG & Modelo de circulación general \\
\hline GHG & Greenhouse gas & GEI & Gases de efecto invernadero \\
\hline GLM & Generalized linear model & MLG & Modelo lineal generalizado \\
\hline IPCC & $\begin{array}{c}\text { Intergovernmental Panel } \\
\text { on Climate Change }\end{array}$ & & $\begin{array}{c}\text { Grupo Intergubernamental de } \\
\text { Expertos sobre el Cambio } \\
\text { Climático }\end{array}$ \\
\hline $\mathrm{RCP}$ & $\begin{array}{c}\text { Representative } \\
\text { Concentration Pathways }\end{array}$ & & $\begin{array}{c}\text { Trayectorias de Concentración } \\
\text { Representativa }\end{array}$ \\
\hline SDM & $\begin{array}{l}\text { Species distribution } \\
\text { models }\end{array}$ & MDE & $\begin{array}{l}\text { Modelos de distribución de } \\
\text { especies }\end{array}$ \\
\hline
\end{tabular}




\section{INTRODUCCIÓN}

Una de las mayores preocupaciones en la actualidad para la comunidad científica es cómo afectará el cambio climático a la biodiversidad. Actualmente hay evidencias de que algunos de los sistemas físicos y biológicos del mundo ya se encuentran afectados por el cambio climático (p.e. Lenoir y Svenning, 2015, Morueta-Holme et al., 2015 y Rosenzweig et al., 2008), particularmente debidos a los incrementos en las temperaturas (IPCC, 2014). Por ejemplo, en España se pronostica que el cambio climático provocará un aumento de las temperaturas mínimas y máximas, además de una reducción significativa de las precipitaciones (Herrero and Zavala, 2015 y Moreno et al., 2005). Estas variaciones provocarán cambios en las áreas de distribución de las especies, así como desplazamientos altitudinales y latitudinales de la vegetación con probables alteraciones en los ecosistemas (Lenoir y Svening, 2015).

Para analizar los impactos potenciales que el cambio climático tendrá en un territorio es necesario conocer la sensibilidad de los ecosistemas frente a las variaciones de las condiciones ambientales, tal como reconoce la Convención Marco de las Naciones Unidas sobre el Cambio Climático (CMNUCC, 1992). La cuantificación de esta sensibilidad permite el desarrollo de estrategias de adaptación y planificación de los territorios frente al cambio climático. La sensibilidad es el grado en que un sistema ecológico resulta afectado, negativa o positivamente, por estímulos relativos al clima que constituyen el ecosistema (IPCC, 2007). La sensibilidad de la vegetación al cambio climático se puede estudiar mediante cambios en la distribución de la especie. Para ello se debe estudiar cada especie por separado teniendo en cuenta sus requerimientos ecológicos y analizar las diferencias entre la distribución de la especie en la actualidad y la distribución en el futuro. Estas diferencias en la superficie potencial de la especie nos permiten caracterizar la sensibilidad de la especie frente al cambio climático. De esta forma, si se obtiene una reducción fuerte de la superficie potencial futura de la especie, se considera que la especie es muy sensible al cambio climático frente a otra en la que apenas haya variación en su distribución.

Una herramienta habitual para estimar las distribuciones potenciales en el presente y futuro y cuantificar la sensibilidad de la especie son los modelos de distribución de especies (MDE). Estos modelos pueden ser mecanicistas o correlativos, los mecanicistas usan rasgos funcionales y límites fisiológicos para identificar la tolerancia de una especie a las condiciones ambientales y predecir la respuesta de un individuo (o una población) a esas 
condiciones (Kearney et al., 2010 y Morin y Thuiller, 2009). Los modelos correlativos, en cambio, relacionan estadísticamente las presencias de una especie con variables ambientales, extrapolando la relación a un territorio para predecir su idoneidad (ver revisiones de: Elith y Leathwick, 2009, Franklin, 2010 y Guisan y Zimmermann, 2000). Los modelos mecanicistas pueden proporcionar una imagen más fiable y realista ya que pueden incluir explícitamente procesos que limitan la distribución de las especies mientras que los modelos correlativos capturan implícitamente estos procesos (Kearney et al., 2010).

No obstante los modelos correlativos son los más utilizados, particularmente en estudios de cambio climático (Araújo y Peterson, 2012 y Thuiller et al., 2005) y en toma de decisiones en conservación (Araújo et al., 2011). Asimismo, se han utilizado para describir patrones ecológicos y estimar el nicho ecológico o la distribución potencial de las especies (Elith y Leathwick, 2009), en biogeografía (Svenning et al., 2008), en la gestión de especies y territorios (Araújo et al., 2007, Arribas et al., 2012 y Schwartz, 2012), en el diseño de muestreos en campo para localizar nuevas poblaciones de una especie o muestreos dirigidos, en el estudio del potencial invasor en especies invasoras (Ficetola et al., 2007 y Gallien et al., 2012), para estudiar patrones espaciales de biodiversidad en macroecología (Svenning y Skov, 2007) e incluso para predecir el patrón geográfico de propagación de enfermedades infecciosas (Bhatt et al., 2013).

En concreto, estos modelos nos permiten estudiar cómo varía la distribución de las especies en el espacio y en el tiempo, por ejemplo, al proyectar los modelos bajo las condiciones climáticas de los escenarios futuros (IPCC, 2014). Sin embargo, al generar los modelos de distribución de especies (MDE) no se obtiene una visión completa de los impactos derivados del cambio climático sobre la persistencia de las poblaciones o los servicios ecosistémicos (Graham et al., 2012). No obstante, los MDE proporcionan información objetiva de qué especies o regiones serán más susceptibles al cambio climático y por tanto, permiten identificar especies y regiones de gran importancia para la conservación. De este modo, constituyen una herramienta muy útil para la toma de decisiones en la gestión adaptativa y conservación de ecosistemas forestales frente al cambio climático. Si se combinan los MDE correlativos con información fisiológica, demográfica y genética, entonces el estudio de los impactos del cambio climático (o el cambio global si se incluye el cambio de uso del suelo) sobre esa región, es mucho más completo (Graham et al., 2012). 
Esta tesis doctoral está enfocada en la reducción de la incertidumbre de los MDE correlativos, que es fundamental para obtener predicciones fiables y robustas al proyectar los mismos en el tiempo y espacio. Para ello se evalúa el efecto de diferentes factores del proceso de modelización en su transferibilidad temporal y espacial. Por un lado se profundiza en la mejora de los datos de partida para calibrar los modelos (datos de presencia actual, datos paleobotánicos y datos climáticos), prestando atención a los datos necesarios para representar la distribución natural actual de la especie, a la influencia de las poblaciones marginales en la predicción de los modelos y a la variabilidad de las predicciones debida a las bases de datos climáticas. Asimismo se profundiza en aspectos metodológicos de los modelos, como es la influencia de la complejidad de los modelos y el uso de umbrales de corte en la incertidumbre y transferibilidad temporal de los modelos. Por último se aborda el uso de los datos paleobotánicos y de imágenes de satélite, como herramienta para la validación de los modelos generados. En esta tesis doctoral, solo se utilizan, por tanto, modelos de distribución de especies correlativos y serán abreviados, a partir de ahora, con las siglas MDE.

\subsection{LIMITACIONES DE LOS MODELOS DE DISTRIBUCIÓN DE ESPECIES}

Pese al impulso experimentado por los MDE correlativos, estos presentan varias limitaciones significativas, como son (Mateo et al., 2011): a) la asunción de que la población o especie está en equilibrio o pseudoequilibrio con las condiciones ambientales, b) la no inclusión de las relaciones bióticas en los modelos (generalmente no se incluyen los fenómenos de interacción entre especies, como competencia o facilitación), c) la ausencia de las componentes espacial y temporal en el modelo, d) la dificultad de generar modelos fiables para especies generalistas, y por último e) la generación de modelos con todos los datos de una especie sin tener en cuenta la variabilidad intraespecífica y la plasticidad fenotípica de las diferentes poblaciones de la especie (Benito-Garzón et al., 2011).

Además de las limitaciones intrínsecas a los modelos, se ha observado que al proyectar geográficamente los modelos de distribución de especies bajo las condiciones climáticas actuales y bajo escenarios futuros de cambio climático, existen grandes diferencias entre los resultados (Elith y Graham, 2009). Incluso para el mismo escenario de emisiones de gases de efecto invernadero, dependiendo del modelo climático usado, los impactos en la vegetación futura son distintos (Felicísimo, 2011). Diversos estudios han determinado que las diferencias entre los resultados de los modelos son debidas en gran medida al algoritmo de modelización y los modelos generales de circulación atmosférica (Buisson et al., 2010 y Nenzén y Araújo, 2011). 
Asimismo, los datos de partida tienen una gran influencia en los resultados del modelo (Dormann et al., 2008): el tipo de datos de la especie (presencia-ausencia o sólo datos de presencia [Elith y Graham, 2009]), el tipo de ausencias (ausencias verdaderas o pseudoausencias [Mateo et al., 2010 y Phillips et al., 2009]), la inclusión de los errores de georreferenciación de los datos de presencia (Graham et al., 2008), la cantidad de datos y características de la especie como su distribución geográfica (amplia o restringida) y su tolerancia ambiental (Hernandez et al., 2006) y el sesgo en las presencias (Phillips et al., 2009 y Varela et al., 2014). A su vez, la elección de las variables predictoras (Harris et al., 2013 y Synes y Osborne, 2011), la extensión del área de estudio (Buisson et al., 2010 y Lobo et al., 2008) y otras decisiones en las etapas del proceso de modelización (como la elección del umbral o la complejidad de los modelos) también afectan a las proyecciones de los modelos y a su capacidad predictiva (Benito et al., 2013, Cao et al., 2013 y Nenzén y Araújo, 2011).

Por ello, para obtener predicciones espaciales y temporales fiables que nos permitan estudiar con mayor precisión los impactos derivados del cambio climático en las especies es imprescindible validar los modelos con datos independientes de los utilizados en la calibración del modelo (Araújo et al., 2005). En el presente los modelos pueden validarse con datos actuales diferentes a los utilizados para calibrar el modelo (Araújo et al., 2005) como son por ejemplo, los que proceden de otros muestreos diferentes e independientes (Eskildsen et al., 2013) o imágenes de satélite. En otros periodos temporales, sí es posible realizar esta validación con datos independientes, mediante la comparación, por ejemplo, de los modelos con datos paleobotánicos (Rodríguez-Sánchez y Arroyo, 2008), permitiendo evaluar la transferibilidad temporal de los modelos hacia el pasado.

\subsection{INTERPRETACIÓN DE LOS MODELOS DE DISTRIBUCIÓN DE ESPECIES. ¿QUÉ ESTAMOS MODELIZANDO?}

Actualmente existe una gran variabilidad en cuanto a la denominación de los modelos, y sobre lo que estos describen y predicen (Araújo y Peterson, 2012, Franklin, 2010, Mateo et al., 2011 y Soberón y Peterson, 2005). Las denominaciones usadas por los autores [p.e. modelos de nicho ecológico (ecological niche models), modelos de idoneidad (suitability models), modelos predictivos del hábitat (predictive habitat distribution models), modelos bioclimáticos (bioclimatic models), envueltas climáticas (climate envelopes) o modelos de distribución de especies (species distributions models)] están influidas por la interpretación ecológica que se hace de los resultados (Araújo y Peterson, 2012 y Mateo et al., 2011). El término de nicho ecológico describe el ajuste o distribución de la especie en el espacio 
ambiental, mientras que en los últimos años, se ha generalizado el uso del término modelos de distribución de especies (species distribution models), que hace referencia al modelo geográfico de la idoneidad de una especie en un territorio (Araújo y Peterson, 2012, Franklin, 2010 y Mateo et al., 2011).

El área de distribución de una especie es el resultado de su ecología e historia evolutiva que se ve determinada por factores operando con diferentes intensidades y escalas (Brown, 1995 y Soberón y Peterson, 2005). Simplificando, el área de distribución de una especie se encontraría determinada por cuatro factores: 1) condiciones abióticas del medio (clima, condiciones edáficas, etc) que constituyen los límites fisiológicos en los que la especie persiste, 2) factores bióticos, que son las interacciones con otras especies que modifican la capacidad de la especie de mantener sus poblaciones y que pueden ser positivas (como mutualismo o facilitación) o negativas (como competencia, depredación o parasitismo), 3) regiones accesibles para la dispersión de la especie capacidad de dispersión de la misma y 4) la capacidad de la especie para adaptarse a nuevas condiciones (Soberón y Peterson, 2005).

Una especie está presente en un lugar cuando se dan tres condiciones (Fig. 1.1, región $\mathbf{P}$, en la intersección de las tres regiones $\mathbf{A}, \mathbf{B}$ y $\mathbf{M}(\mathbf{A} \cap \mathbf{B} \cap \mathbf{M})$ [Soberón y Peterson, 2005]): 1) condiciones abióticas favorables (climáticas y topográficas) (región A), 2) las especies necesarias están presentes (simbiosis, hospedadoras, polinizadores, dispersoras, micorrizas) y las que excluirían su presencia están ausentes (competidores excluyentes, depredadores, enfermedades) (región B) y 3) la especie tiene acceso a la región $\mathbf{M}$ por dispersión.

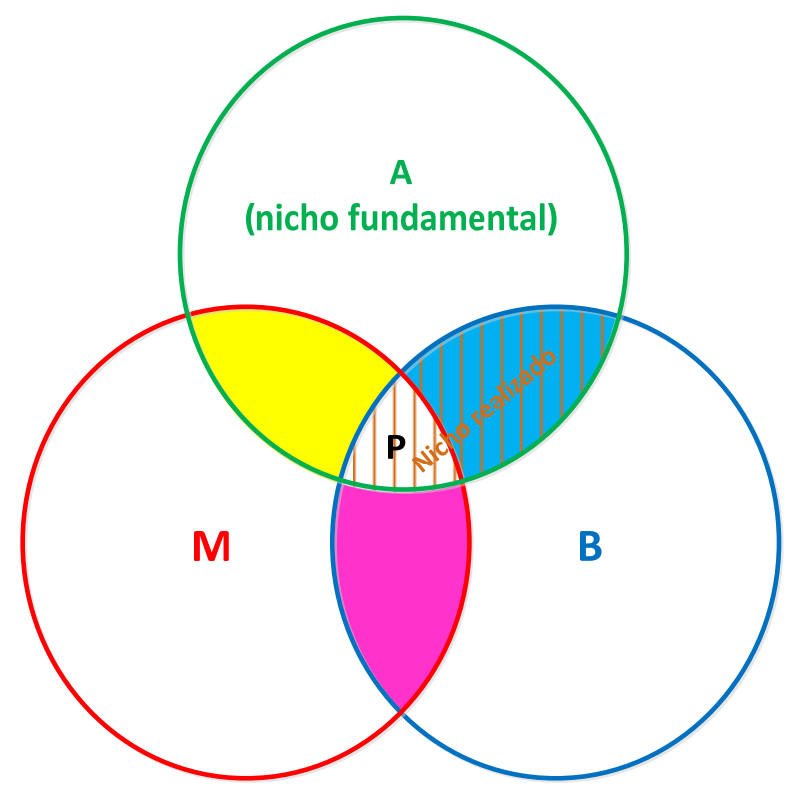

Fig. 1.1. Explicación gráfica en el espacio ambiental del área ocupada por una especie, el nicho fundamental (FN) y el nicho realizado (RN). Fuente: Modificado de Soberón y Peterson (2005). 
En la Fig. 1.1, La región $\mathbf{A}$, en verde, es la representación geográfica del nicho fundamental de la especie (Hutchinson, 1957) y corresponde al área geográfica con el conjunto adecuado de factores abióticos en los que la especie puede persistir y tener un crecimiento de la población. La región $\mathbf{B}$, en azul, es la región con el ambiente biótico adecuado en la que se produce la interacción de especies que puede o no solaparse con la región A. La intersección entre la región $\mathbf{A}$ y $\mathbf{B}(\mathbf{A} \cap \mathbf{B})$ es representación geográfica del nicho realizado de la especie (Hutchinson, 1957). El nicho realizado es el subconjunto que la especie ocupa del nicho fundamental de la especie, el resto del nicho fundamental no es ocupado como resultado de las interacciones bióticas (Miller, 2010).

Los puntos de presencia actual de una especie están dentro del nicho realizado, aunque pueden existir partes del nicho realizado de la especie sin puntos de presencia debido a un muestreo insuficiente o una baja detectabilidad de la especie (Miller, 2010). Al trasladar el espacio ambiental del nicho fundamental y realizado al espacio geográfico, el nicho fundamental sería la distribución potencial y el nicho realizado sería la distribución real o actual de la especie. Se considera que en el espacio ambiental, el nicho fundamental es estático mientras que la distribución potencial de la especie cambia al variar las condiciones ambientales para mantenerse en equilibrio con el clima (Miller, 2010).

Entender qué se modeliza es muy importante para la interpretación de los resultados y la aplicación de los modelos de distribución de especies. Según Soberón y Peterson (2005), la mayoría de los algoritmos bioclimáticos estiman el nicho fundamental. Sin embargo, en sentido estricto, como los MDE se basan en datos observados que pueden estar sujetos a interacciones bióticas, alteraciones, competencia y limitaciones a la dispersión, entre otras restricciones, el mapa de distribución potencial que obtenemos con el modelo no sería exactamente el nicho fundamental y tampoco coincidiría con el nicho realizado, a no ser que contemos con variables que representen las interacciones bióticas o las perturbaciones (Miller, 2010). Estas consideraciones están en debate actualmente y aunque afectan a la interpretación de los resultados de los modelos (Soberón y Peterson, 2005, Franklin, 2010, Miller, 2010 y Araújo et al., 2012). En esta tesis se considera que la distribución potencial de la especie obtenida a partir de las presencias actuales sin usar ausencias verdaderas y sin incluir las interacciones bióticas sería una estimación del nicho fundamental de la especie siguiendo Soberón y Nakamura (2009) y por tanto, una estimación del espacio ambiental y geográfíco de las condiciones abióticas donde la especie puede persistir y reproducirse. 


\subsection{EL PROCESO DE MODELIZACIÓN}

Para generar los MDE es necesario seguir un proceso (Fig. 1.2) que se puede resumir en tres pasos principales: 1) la recopilación de los datos de presencia de la especie (variable respuesta) y obtención de los valores de las variables ambientales (variables predictoras) en el área de estudio, 3) el ajuste de los modelos de predicción de idoneidad de presencia de la especie a partir de los valores de las de las variables ambientales en las presencias de la especie y por último, 4) la predicción de la idoneidad de presencia de la especie en el área de interés y su proyección espacio-temporal bajo diferentes condiciones climáticas (presente, pasado o futuro).

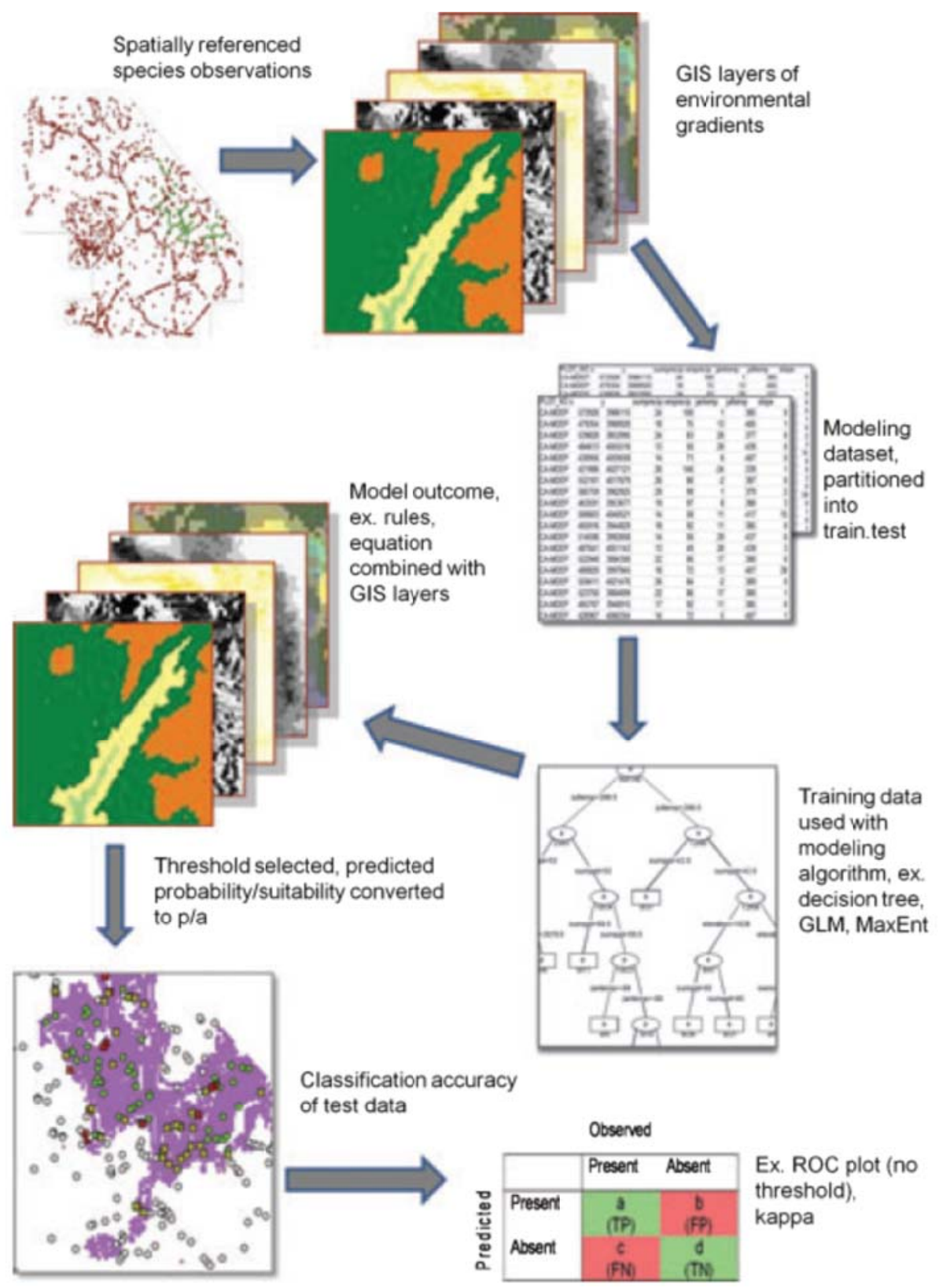

Fig. 1.2. Flujo de trabajo en el proceso de modelización (Miller, 2010). 


\subsubsection{Obtención de datos: Datos de la especie y variables ambientales}

La primera parte del proceso consiste en la preparación de los datos sobre los que se va a trabajar. Este es uno de los puntos clave del proceso de modelización y en el que se invierte gran parte del tiempo debido a que se necesita una gran cantidad de datos de presencia (y a ser posible de ausencia) de la especie, sin errores y con una referenciación precisa e información ambiental del área de estudio con una adecuada resolución espacial.

\section{Distribución actual de las especies}

Antes de generar los modelos es imprescindible analizar y preparar los datos de presencias/ausencias de las especies. De este modo se eliminarán los posibles errores existentes en los datos. Este proceso es especialmente importante para depurar los datos de presencias de especies obtenidos de bases de datos globales con grandes sesgos en los datos como GBIF (http://www.gbif.org/). En esta base de datos se han observado problemas derivados de las diferencias en la precisión en las coordenadas, la identificación taxonómica o porque el esfuerzo de muestreo no es uniforme entre distintas zonas (Beck et al., 2014 y Mateo et al., 2013).

Entre los procesos necesarios en el tratamiento de datos están: la correcta identificación de las especies (eliminar presencias con dudas en la identificación o aquellas mal identificadas), la eliminación de presencias duplicadas, la verificación de la correcta referenciación de las presencias (eliminar o corregir aquellas discrepancias entre los campo de coordenadas con el de localidad o país) (Hijmans y Elith, 2013) y la eliminación de presencias con alto sesgo de muestreo (en los herbarios en general hay una infrarrepresentación de especies comunes) o con baja precisión en las coordenadas (algunos pliegos de herbario se digitalizan y publican en bases de datos con precisión de coordenadas de más de 20 kilómetros, los que no permite localizar el punto con precisión en el espacio geográfico ni relacionarlo con datos climáticos cuya resolución es de $1 \mathrm{~km}$ ).

Otra consideración importante en cuanto a los datos de presencia de la especie, es que estos datos deben representar adecuadamente la distribución actual de la especie a modelizar (Hijmans y Elith, 2013). Por ello, hay que modelizar la especie con todas las presencias de su área natural de distribución y no solo aquellas que estén en el territorio de estudio. De este modo, se recogerá en el modelo todo el rango ambiental de la especie, minimizando los riesgos de extrapolación fuera de la zona de entrenamiento de las variables ambientales. 


\section{Variables ambientales}

Para realizar los MDE además de registros de presencia de la especie, es necesario disponer de información ambiental (temperatura, precipitación, topografía, tipo de suelo, etc) del área de estudio. Estas variables ambientales pueden ser continuas como la precipitación y la temperatura o categóricas, como el tipo de suelo. Una de las bases de datos más usadas para generar los MDE es WORLDCLIM (http://www.worldclim.org; Hijmans et al., 2005). Esta base de datos dispone de datos climáticos globales de libre acceso y uso. Consta de 19 variables bioclimáticas derivadas de las temperaturas y precipitaciones mensuales para el periodo 1950-2000 obtenidas mediante la interpolación de datos climáticos de estaciones meteorológicas. Estas variables (Tabla 1.1) tienen gran sentido biológico como factores limitantes a la hora de explicar la distribución de los organismos, ya que no sólo muestran tendencias mensuales sino que también incluyen tendencias trimestrales importantes para la vegetación (Hijmans et al., 2005 y Kumar y Stohlgren, 2009).

Tabla 1.1. Variables bioclimáticas disponibles en la base de datos WORLDCLIM (Hijmans et al., 2005)

\begin{tabular}{|c|c|}
\hline Código & Descripción \\
\hline BIO 01 & Temperatura media anual \\
\hline BIO 02 & Rango diurno de temperaturas (media mensual (max temp - min temp)) \\
\hline BIO 03 & $\begin{array}{c}\text { Isotermalidad: Relación entre el rango de temperaturas entre el día y la noche y entre el verano e } \\
\text { invierno (BIO02/BIO07) }(* \text { 100) }\end{array}$ \\
\hline BIO 04 & Estacionalidad en la temperatura (desviación estándar*100) \\
\hline BIO 05 & Temperatura máxima del mes más cálido \\
\hline BIO 06 & Temperatura mínima del mes más frío \\
\hline BIO 07 & Rango de temperatura anual (BIO05-BIO06) \\
\hline BIO 08 & Temperatura media del trimestre más húmedo \\
\hline BIO 09 & Temperatura media del trimestre más seco \\
\hline BIO 10 & Temperatura media del trimestre más cálido \\
\hline BIO 11 & Temperatura media del trimestre más frío \\
\hline BIO 12 & Precipitación anual \\
\hline BIO 13 & Precipitación del mes más húmedo \\
\hline BIO 14 & Precipitación del mes más seco \\
\hline BIO 15 & Estacionalidad en la precipitación (Coeficiente de variación) \\
\hline BIO 16 & Precipitación del trimestre más húmedo \\
\hline BIO 17 & Precipitación del trimestre más seco \\
\hline BIO 18 & Precipitación del trimestre más cálido \\
\hline BIO 19 & Precipitación del trimestre más frío \\
\hline
\end{tabular}

WORLDCLIM también también dispone de variables climáticas para el pasado a partir de modelos de circulación general acoplados atmósfera-océano (AOGCM) del proyecto Paleoclimate Modelling Intercomparison Project (PMIP2, http://pmip2.lsce.ipsl.fr/) para el: 6.000 años cal BP (Holoceno Medio) y 21.000 años cal BP (Último Máximo Glacial) (http://www.worldclim.org/past).

Las bases de datos de clima futuro también se pueden obtener a través de WORLDCLIM (http://www.worldclim.org/cmip5v1) para las proyecciones del $5^{\circ}$ Informe del Grupo 
Intergubernamental de Expertos sobre el Cambio Climático (IPCC5) para los periodos temporales $2050(2041-2060)$ y 2070 (2061-2080) y cuatro trayectorias de concentración representativas (RCPs) $(2.6,4.5,6.0$ y 8.5) para diferentes modelos de circulación general (GCM).

\section{Selección de las variables ambientales}

La elección de las variables ambientales es otra parte importante y compleja del proceso de generación de los modelos, que influye especialmente en las proyecciones al futuro (Harris et al., 2013). Es necesario analizar previamente la correlación existente entre las variables para evitar incluir variables correlacionadas en el mismo modelo, lo que aportaría información redundante afectando negativamente a la capacidad predictiva del modelo. La reducción de variables se puede realizar mediante un análisis de componentes principales (Miller, 2010). Dado que es difícil la interpretación biológica de los distintos componentes o ejes resultantes, otra técnica muy utilizada para eliminar variables correlacionadas consiste en realizar un análisis de correlación de las variables ambientales en los puntos de presencia de la especie o en puntos al azar del área de estudio, calculando el coeficiente de correlación de Pearson. Las variables se comparan dos a dos para descartar la variable con menor sentido biológico y con mayor correlación con el resto de variables cuando el coeficiente de correlación es superior a cierto valor (Morueta-Holme et al., 2010). Asimismo se puede realizar un análisis de factor de inflación de varianza (variance inflation factor) de las variables climáticas para eliminar variables correlacionadas y que puedan presentar problemas de multicolinealidad.

\subsubsection{Generación de los modelos de distribución de especies}

Después de la preparación de los datos de presencia y ausencia de la especie y de los datos ambientales se procederá a la calibración o construcción del modelo, y a su posterior validación.

\section{$>$ Elección del algoritmo de modelización.}

La elección del algoritmo de modelización es una parte muy importante del proceso de modelización que también influye en los resultados de los modelos (Elith y Graham, 2009). Entre los diferentes tipos de algoritmos, existentes (p.e. Guisan y Zimmermann, 2000, Elith et al., 2006, Elith y Leathwick 2009 y Franklin, 2010), hay que seleccionar la mejor opción acorde con las características de nuestros datos biológicos y ambientales, y el objetivo del trabajo (Miller, 2010). 
En general, existen tres grupos de algoritmos de modelización:

i) Las técnicas descriptivas "profile", que sólo usan datos de presencia de la especie (no usan ni ausencias ni background). Entre estos algoritmos se encuentran: Bioclim, Domain y distancia de Mahalanobis.

ii) Los métodos discriminantes, que necesitan datos de presencia y ausencia de la especie para poder generar el modelo. En este grupo se incluyen los métodos de regresión "regression" como son los modelos lineales generalizados (GLM), los modelos aditivos generalizados (GAM) o la Regresión Adaptativa Multivariante (MARS).

iii) Los "machine learning methods" incluyen a los algoritmos: Random Forests, Boosted Regression Trees, Artificial Neural Networks (ANN) y Maxent. Estos algoritmos, junto con los de regresión, necesitan datos de presencia y ausencia de la especie aunque algunos como Maxent, son capaces de generar sus propios puntos (background) para definir ambientalmente el área de estudio.

La distinción entre estos últimos modelos y los de regresión no es muy clara. Recientemente se ha demostrado que Maxent es equivalente matemáticamente a una regresión de Poisson, que es un tipo de GLM (Renner y Warton, 2013). Sin embargo, se considera que los machine learning methods (MLM) están más dirigidos por los datos y no están basados en funciones de distribución específicas como la distribución de Poisson o la binomial de los GLM. Estos métodos son muy usados para análisis exploratorios. Asimismo los MLM dividen las observaciones a lo largo del espacio ambiental y son considerados más locales, al contrario que los GLM, que ajustan el modelo considerando todas las presencias y datos ambientales al mismo tiempo (Miller, 2010).

En resumen, para elegir el algoritmo de modelización se deben tener en cuenta los siguientes aspectos:

1) Datos de entrada: Si se tienen datos de presencia y ausencia de la especie, se pueden usar algoritmos de regresión como GLM y GAM. Si solo se dispone de datos de presencia de la especie, se recomienda usar Maxent $\mathrm{u}$ otras técnicas como Bioclim, GARP o BIOMAPPER.

2) La relación entre la especie y el ambiente: Hay que estudiar el tipo de respuesta de la presencia de la especie frente a las variables ambientales (Merow et al., 2013). 
3) Objetivo de la modelización: es importante tener claro el objetivo de la modelización ya que la interpretación del modelo cambia si, por ejemplo, se pretende modelizar el área que podría ocupar una especie invasora en un territorio, si se está estudiando la ecología de la especie o si en cambio, se quiere proyectar la distribución de la especie bajo escenarios climáticos diferentes.

En esta tesis se ha utilizado el algoritmo Maxent, acrónimo de las palabras inglesas Maximum entropy que es el principio estadístico en el que se basa (Phillips et al., 2006; Phillips y Dudík, 2008). Maxent está considerada como una técnica discriminante (necesita presencias y ausencias), que sin embargo permite generar modelos solo con datos de presencia ya que es capaz de generar sus propias "ausencias" denominadas background (Phillips et al., 2006; Phillips y Dudík, 2008). Esta técnica se utiliza frecuentemente en estudios que proyectan las distribuciones actuales de las especies hacia diferentes periodos temporales (Elith et al., 2011) y se ha elegido principalmente por estos motivos: 1) muestra buenos resultados en las comparaciones con otros métodos de modelización ecológica (Elith et al., 2006); 2) no necesita datos de ausencia (Phillips et al., 2006); 3) permite la interpretación biológica de los resultados; y 4) su uso está implementado en la plataforma $\mathrm{R}$ a través del paquete "dismo" (Hijmans et al., 2015). Maxent es uno de los algoritmos más usados en MDE y además, ha resultado ser muy eficaz en estudios en los que se dispone pocas presencias (Miller, 2010 y Shcheglovitova y Anderson, 2013).

Maxent calcula la probabilidad de distribución de máxima entropía (la distribución más próxima a la uniforme) de forma que el valor esperado de cada variable independiente (valor medio predicho por el modelo) debe coincidir con su media empírica (valor medio observado al muestrear las variables independientes con los datos de presencia de partida). Una de las ventajas de Maxent es que permite valorar la influencia de las variables ambientales sobre el modelo final. Además produce otros gráficos en los que se indica la importancia de cada variable ambiental en la distribución de la especie (Mateo, 2008 y Elith et al., 2011).

\section{$>$ Calibración de los modelos de distribución de especies}

Para construir los MDE es necesario disponer de presencias observadas, o presencias y ausencias observadas que informen sobre la distribución actual de la especie objeto de estudio. Las presencias y ausencias verdaderas (ausencias estrictas) de la especie, constituyen observaciones fiables derivadas de un inventario de campo. Ambos datos son muy valiosos y permiten el uso de algoritmos de regresión como GLM y GAM. Sin embargo, las ausencias 
son difíciles de obtener e incluyen sesgos en el modelo ya que pudiera ser que la especie no se encuentre en la zona inventariada por incompatibilidad con el clima o por otros motivos, como la desaparición por la acción del hombre, por contingencia (factores derivados del azar), o que estando presente haya pasado desapercibida en el inventario.

Si no se dispone de datos de ausencias verdaderas, el algoritmo de modelización necesitará o generará su propio set de puntos para que el modelo clasifique entre presencias y ausencias (Hanberry et al., 2012). Las pseudo-ausencias son datos que simulan ausencias y se pueden generar en lugares bien muestreados en los que se tiene constancia de que la especie objetivo no está presente (Mateo et al., 2010). Aunque el uso de pseudo-ausencias puede hacer que aumente el error de omisión en el que una presencia real es predicha como ausencia por el modelo (Mateo et al., 2010). Otro tipo de ausencias para la generación de modelos son los datos de background que no son considerados como verdaderas ausencias por el modelo si no puntos al azar dentro del área de estudio que permiten caracterizar el espacio ambiental donde la especie se desarrolla (Phillips y Dudík, 2008).

En cuanto al número de presencias a usar en el modelo, muy pocas presencias puede conducir a generar un modelo insuficiente, que no represente de forma adecuada la distribución de la especie. Sobre todo teniendo en cuenta que hay que dividir las presencias en dos grupos para validar el modelo en los casos en los que no se dispone de datos independientes. En cambio, usar muchas presencias puede conducir a problemas de overfitting o sobreajuste del modelo a los datos. Este overfitting se puede corregir en Maxent mediante el uso del parámetro $\beta$-multiplier, que permite que la respuesta de las variables sea más relajada y no tan rígida como le determinan los datos (Merow et al., 2013).

Para generar modelos con un adecuado poder analítico se recomienda vigilar la relación entre el número de presencias y el número de variables ambientales (variables predictoras) que se van a usar en el modelo. Algunos autores (Vaughan y Ormerod, 2003) recomiendan usar una relación de mínimo 10 presencias por cada variable predictora aunque este ratio puede verse afectado por la autocorrelación espacial y la mulicolinearidad (Miller, 2010). Otros autores sugieren una relación de 20 a 1 o incluso de 40 a 1 (Miller, 2010).

Si se dispone de datos de presencia y ausencia hay que observar la "prevalencia" (prevalence), que es la relación existente entre presencias y ausencias de una especie ya que la tasa de identificación correcta de las presencias (sensitivity) se ve afectada por la prevalencia en algunos métodos. En métodos independientes de la prevalencia, se ha observado que una 
prevalencia cercana a 0.5 ha sido asociada con modelos más precisos en sus predicciones (McPherson et al., 2004). Aunque otros estudios han mostrado que las especies raras (con baja prevalencia), son modelizados con mayor precisión y exactitud que otras especies con mayor prevalencia, debido a que sus correlaciones ambientales son más fuertes (Franklin et al., 2009 y Segurado y Araújo, 2004).

Una vez preparados los registros de presencias de la especie en el área de estudio, se realizará una partición de los datos en dos grupos de datos (Fig. 1.3), datos de calibración y datos de evaluación, lo que implica tener un número suficiente de presencias de la especie (Mateo et al., 2011). El set de datos de calibración se usará para construir o entrenar el modelo y el set de datos de evaluación se usará para evaluar el modelo, es decir, para comprobar la calidad del modelo en datos diferentes a los usados para construir el modelo.

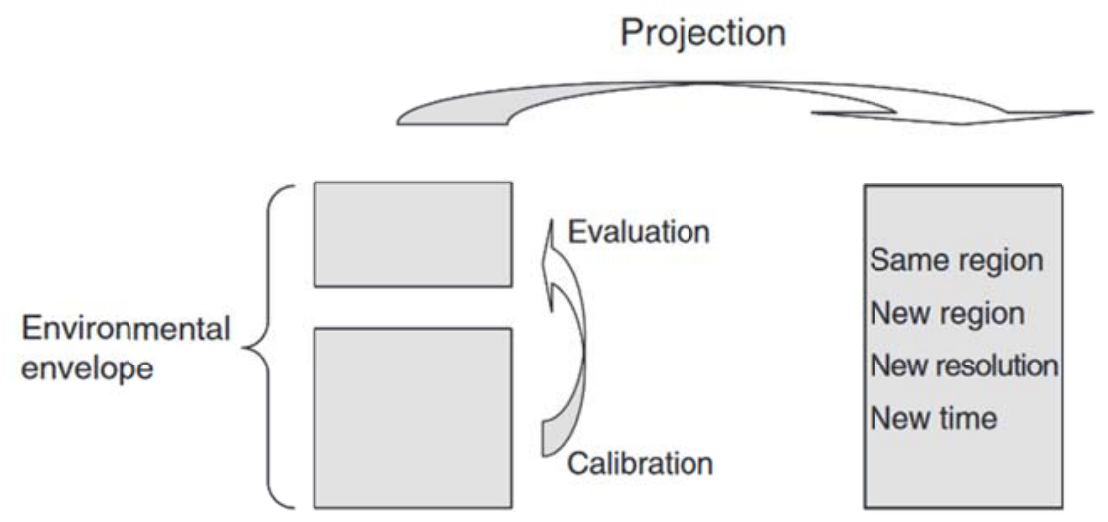

Fig. 1.3. División de los datos para la calibración y evaluación de los modelos de distribución de especies. Fuente: Araújo et al., 2005 .

\section{$>$ Validación de los modelos de distribución de especies}

Los resultados del MDE deben ser evaluados estadísticamente para ver la capacidad predictiva del modelo es decir, es necesario evaluar su capacidad de clasificar correctamente las presencias y ausencias observadas de la especie. Para tener una evaluación robusta se requieren datos de validación independientes a los de calibración. Para evaluar los modelos se puede realizar la validación cruzada (cross-validation) y la división de los datos en datos de calibración y de test puede ser aleatoria (al azar) o una división espacial (Morueta-Holme et al., 2010). La "k-fold cross validation" es la validación cruzada a partir de la partición aleatoria de los datos en $\mathrm{k}$ particiones usando (k-1) particiones para calibrar el modelo y la restante para evaluarlo. El proceso se repite para cada una de las k particiones, y se calcula la media de las métricas de evaluación de cada modelo generado. Esta división de los datos al azar es de las más utilizadas en MDE, aunque no tiene en cuenta el efecto de la 
autocorrelación espacial de los datos en las métricas de evaluación, como en el AUC (área bajo la curva ROC) que podría aumentar artificialmente (Veloz, 2009). En cambio existen otras formas de división de los datos que crean particiones espacialmente independientes, como el "distance splitting approach" que impone una distancia mínima entre los datos de calibrado y validación (Harris, 2015), o el "block method" que divide los datos en 4 bloques según las líneas de latitud y longitud que separan las presencias (Muscarella et al., 2014). Este último método se ha demostrado como el adecuado en estudios que incluyen transferencia espacial o temporal de los MDE y en aquellos en los que se puedan encontrar condiciones ambientales no análogas, como en estudios de cambio climático o de especies invasoras (Muscarella et al., 2014).

Una vez se tiene el set de datos de evaluación del modelo (datos de test), se contrasta la predicción del modelo en esos puntos comparando las presencias/ausencias predichas por el modelo con las presencias/ausencias reales y se evalúa el error que comete el modelo mediante la proporción de casos clasificados incorrectamente (Fig. 1.4). Los errores cometidos pueden ser de dos tipos: a) error de comisión (b en Fig. 1.4 y Fig. 1.5), que consiste en clasificar una ausencia real como presencia (falsos positivos), y b) error de omisión (c en Fig. 1.4 y Fig. 1.5), que consiste en clasificar una presencia real como ausencia (falsos negativos) (Mateo et al., 2011). Los falsos negativos pueden resultar de datos erróneos o inexactitudes del modelo y los falsos positivos pueden resultar de factores bióticos o abióticos que impiden a la especie ocupar el hábitat idóneo, como son las limitaciones de dispersión o las barreras históricas (Miller, 2010).

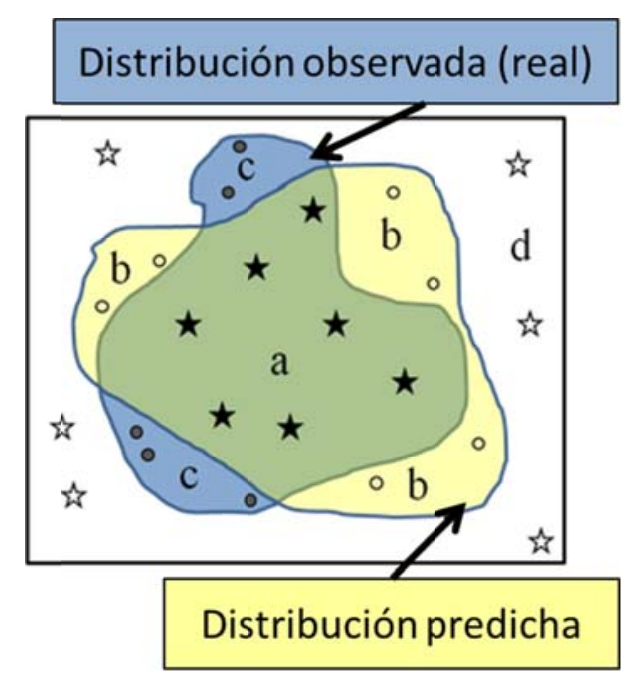

Fig. 1.4. Distribución real de una especie (azul) y distribución predicha por el modelo (amarillo). Los puntos de test usados para evaluar el modelo pueden caer en cuatro áreas: las estrellas son presencias (a) o ausencias (d) bien clasificadas y los círculos son errores es decir, presencias (c) o ausencias (b) mal clasificadas. Fuente: Modificado de Soberón, 2011 (http://nicho.conabio.gob.mx/ consultado: 12-05-2015). 
Hay dos tipos principales de medidas de precisión de los modelos con datos de presencia/ausencia: 1) las medidas basadas en la matriz de confusión (Fig. 1.5) y 2) la curva ROC (receiver-operating characteristic) (Miller, 2010).

\begin{tabular}{|c|c|c|}
\hline & $\begin{array}{c}\text { Presencias } \\
\text { Reales }\end{array}$ & $\begin{array}{c}\text { Ausencias } \\
\text { Reales }\end{array}$ \\
\hline $\begin{array}{c}\text { Presencias } \\
\text { predichas }\end{array}$ & $a$ & $b$ \\
\hline $\begin{array}{c}\text { Ausencias } \\
\text { Predichas }\end{array}$ & $c$ & $d$ \\
\hline
\end{tabular}

Fig. 1.5. Matriz de confusión usada para resumir la clasificación de los puntos para datos categóricosi binarios. Los colores verde y blanco indican resultados correctos y el amarillo y azul, resultados incorrectos. Los puntos situados en a son presencias reales que han sido predichas como presencias, los puntos situados en $\mathbf{d}$ son ausencias reales que han sido predichas como ausencias, los puntos situados en $\mathbf{c}$ son presencias reales que han sido predichas como ausencias y los puntos situados en $\mathbf{b}$ son ausencias reales que han sido predichas como presencias. Fuente Soberón, 2011 (http://nicho.conabio.gob.mx/ consultado: 12-05-2015).

La matriz de confusión agrupa la información relativa a los errores cometidos de omisión y comisión (Fig. 1.4 y Fig. 1.5). Los estadísticos basados en la matriz de confusión evalúan la capacidad discriminativa del modelo, siendo los más utilizados los estadísticos kappa, porcentaje correctamente clasificado (PCC), sensitivity, specificity, y true skill statistic (TSS) (Fig. 1.6). Como estos estadísticos trabajan con predicciones discretas y la mayoría de los algoritmos usados con datos de presencia/ausencia generan predicciones continuas, se debe establecer un umbral para convertir las predicciones de idoneidad (valor continuo) a presencia-ausencia (valor discreto), por encima del umbral el modelo predice presencia y por debajo, ausencia de la especie. La elección de este umbral, que se debe establecer en función del objetivo del estudio, influye en los resultados de los modelos (Miller, 2010).

\begin{tabular}{lll}
\hline Estadístico & Descripción & Cálculo \\
\hline PCC & Percent correctly classified & $(a+d) / n$ \\
Kappa & Difference between prediction accuracy & {$[(a+d)-(((a+c) \times$} \\
& and chance agreement & $(a+b)+(b+d) \times$ \\
& & $(c+d)) / n)] /(n-(((a+c) \times$ \\
& & $(a+b)+(b+d) \times(c+d)) / n)]$ \\
Sensitivity & Proportion of observed present correctly predicted & $a /(a+c)$ \\
Specificity & Proportion of observed absent correctly predicted & $d /(b+d)$ \\
PPP & Proportion of predicted present correctly predicted & $a /(a+b)$ \\
NPP & Proportion of predicted absent correctly predicted & $d /(c+d)$ \\
TSS & True skill statistic & $a /(a+c)+d /(b+d)-1$ \\
\hline
\end{tabular}

Fig. 1.6. Medidas de precisión para evaluar modelos con datos de presencia/ausencia. $a=$ positivos verdaderos (presencias reales predichas como presencias), $\mathrm{b}=$ positivos falsos (ausencias reales como presencias), $\mathrm{c}=$ negativos falsos (presencias 
reales predichas como ausencias), $\mathrm{d}=$ negativos verdaderos (ausencias reales predichas como ausencias) y $\mathrm{n}=\mathrm{a}+\mathrm{b}+\mathrm{c}+\mathrm{d}$. Fuente: Modificado de Miller, 2010.

El segundo tipo de medidas de precisión de los modelos es la curva ROC. El AUC (área bajo la curva ROC) es el estadístico de validación de MDE más usado en la actualidad. La curva ROC es la representación gráfica de la capacidad discriminativa de un modelo, es decir, la capacidad del modelo de distinguir entre presencias y ausencias (Fielding y Bell, 1997). El eje de ordenadas representa la sensibilidad (sensitivity) que es la proporción de presencias observadas correctamente predichas y el de abscisas representa el complementario de la especificidad (1-especificidad), o error de comisión (falsos positivos). La curva ROC es independiente del umbral ya que calcula la sensibilidad y el error de comisión para todos los umbrales (Fig. 1.7) (Miller, 2010).

El área bajo la curva ROC corresponde a la probabilidad de que, al tomar al azar un par de casos, uno de presencia y otro de ausencia, el modelo dé un valor de idoneidad mayor a la presencia que a la ausencia. El valor de AUC varía entre 0 y 1 , siendo 1 el valor que indica que todos los casos se han clasificado correctamente y 0.5 el valor que muestra que el modelo no clasifica los casos de forma distinta a una clasificación al azar. En el caso de usar puntos de background y no verdaderas ausencias, el AUC se interpreta como la probabilidad de que una presencia elegida al azar tenga mayor idoneidad que un punto al azar de background. Este AUC es menos informativo que el generado con verdaderas ausencias ya que el background puede incluir zonas potencialmente no muestreadas (Merow et al., 2013).

En la curva ROC (Fig. 1.7), si la curva roja cae por debajo de la línea negra, indica que el modelo es peor que si se hubiese hecho al azar. En cambio, cuanto más se aproxime la línea roja a la esquina superior izquierda, el modelo tiene mejor capacidad de predicción. 


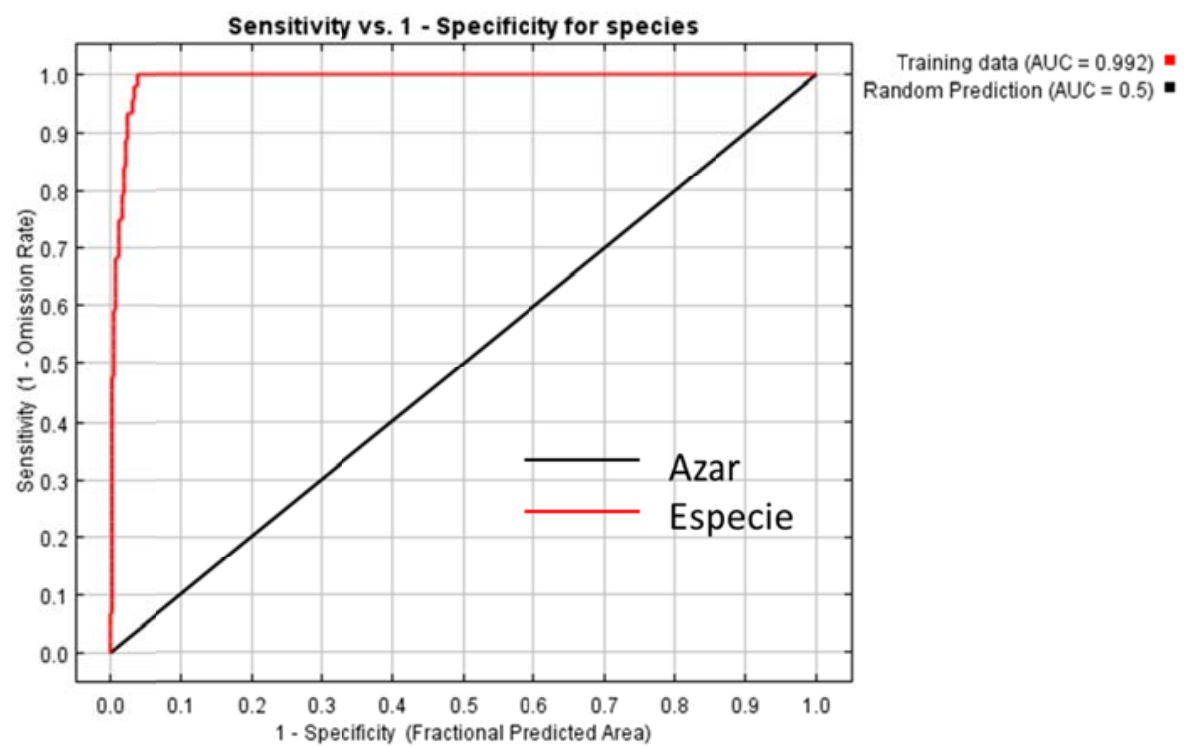

Fig. 1.7. Gráfica del AUC (Área bajo la curva ROC) para la especie Pinus uncinata. La curva roja representa el ajuste del modelo a los datos. La línea negra representa la línea esperada si el modelo no fuese mejor que por azar. La sensibilidad (sensitivity) es la proporción de presencias observadas correctamente predichas y la especificidad (specificity) es la proporción de ausencias observadas correctamente predichas.

El AUC tiene varias ventajas e inconvenientes. Entre las primeras está que permite usarlo para comparar cualquier método y que es una medida independiente del umbral de corte (Mateo et al., 2011). Entre las desventajas o limitaciones, las más importantes son: 1) proporciona el mismo valor al error de comisión que al error de omisión cuando no es igual de importante clasificar una presencia como ausencia teniendo certeza de presencia a clasificar una ausencia como presencia sin tener certeza de ausencia de la especie, 2) no aporta información de la distribución espacial del error del modelo (Mateo et al., 2011), 3) la extensión total del modelo influye de forma importante en este estadístico (Lobo et al., 2008) y 4) no informa de la bondad de ajuste ni la complejidad del modelo (Warren y Seifert, 2011).

El AIC (criterio de información de Akaike) es un estadístico que establece un equilibrio entre la bondad de ajuste del modelo a los datos y la complejidad o número de parámetros del modelo (Johnson y Omland, 2004). Es un estadístico muy usado para la selección de modelos y cada vez más usado en MDE permitiendo obtener de entre un grupo de modelos, aquel de complejidad óptima (Warren y Seifert, 2011 y Muscarella et al., 2014). El AIC selecciona el modelo con mayor bondad de ajuste penalizando el número de parámetros del modelo de forma que a igualdad de ajuste a los datos, el AIC penaliza los modelos de mayor complejidad. El modelo con mayor equilibrio entre la bondad de ajuste del modelo a los datos y complejidad es aquel con el menor valor del AIC. 


\section{$>$ Proyección de los modelos en diferentes periodos temporales}

Los modelos generados para el presente se pueden proyectar bajo condiciones climáticas correspondientes a diferentes periodos temporales, ya sea al pasado (Holoceno Medio y Último Máximo Glacial) o al futuro (escenarios climáticos del IPCC5).

Para realizar las proyecciones de clima futuras y obtener las estimaciones de variación de temperatura y precipitación, se utilizan cuatro escenarios futuros de cambio climático propuestos por el IPCC en su quinto informe (IPCC, 2014). Estos escenarios futuros o trayectorias de concentración representativas (RCP, Representative Concentration Pathways) constituyen diferentes supuestos de emisiones de gases de efecto invernadero (GEI) a la atmósfera para el año 2100. Los RCP junto con el uso de modelos de circulación general (GCM) y modelos de circulación general acoplados atmósfera-océano (AOGCM) permiten generar las predicciones de las variables ambientales en el futuro y predecir la distribución futura de las especies mediante el uso de los MDE.

A la hora de proyectar los MDE bajo diferentes escenarios climáticos de los usados para calibrar el modelo hay que interpretar los resultados cautelosamente ya que los modelos se basan en ciertas asunciones, como la conservación del nicho y el equilibrio de la especie con el clima (Mateo et al., 2011) que pueden no ser ciertas (Svenning y Skov, 2004). Igualmente, al proyectar el modelo, pueden aparecer combinaciones climáticas (novel climates o nonanalogue climates) diferentes a las existentes en el clima presente con el que se ha calibrado el modelo. Esto hace que el modelo no tenga información del comportamiento de la especie en esa nueva combinación climática y tenga que realizar extrapolaciones fuera de los límites de calibración de las variables predictoras (Elith et al., 2010).

\section{$>$ Selección del umbral de corte en los MDE.}

Los umbrales de corte son los valores usados para transformar las predicciones continuas de idoneidad de la especie predichas por el modelo en valores tipo presencia/ausencia que posibilitan el cálculo de áreas y cambios en las distribuciones de las especies. El umbral generalmente se establece en función del objetivo del estudio y no hay unanimidad en su elección (Nenzén y Araújo, 2011), siendo generalmente establecido minimizando el error de comisión u omisión. Un umbral demasiado elevado puede hacer que aumente el error de omisión o falsos negativos (presencias verdaderas predichas como ausencias) y por ello 
algunos autores critican el uso de umbrales para estudiar el área ocupada por una especie en el futuro (Merow et al., 2013).

En el caso de Maxent (Philips et al., 2006 y Philips y Dudík, 2008) se puede elegir entre varios umbrales sugeridos para la especie por el algoritmo que además nos indican el error que cometemos (presencias o ausencias de la especie mal clasificadas) al elegir cada umbral (Tabla 1.2).

Tabla 1.2. Ejemplo de umbral o punto de corte en la salida logística (logistic threshold) de Maxent junto con su descripción (description), la fracción del área total de estudio predicha como presencia (fractional predicted area) y el error de omisión que se comete que indica la proporción de presencias predichas como ausencias (training omission rate).

\begin{tabular}{|c|c|c|c|}
\hline Logistic threshold & Description & Fractional predicted area & Training omission rate \\
\hline \hline 0.008 & Fixed cumulative value 1 & 0.148 & 0.000 \\
\hline \hline 0.053 & Fixed cumulative value 5 & 0.069 & 0.000 \\
\hline \hline 0.120 & Fixed cumulative value 10 & 0.043 & 0.082 \\
\hline \hline 0.059 & Minimum training presence & 0.065 & 0.000 \\
\hline \hline 0.180 & Equal training sensitivity and specificity & 0.036 & 0.094 \\
\hline 0.083 & Maximum training sensitivity plus specificity & 0.052 & 0.047 \\
\hline \hline 0.059 & Balance training omission, predicted area and threshold value & 0.065 & 0.000 \\
\hline \hline 0.017 & Equate entropy of thresholded and original distributions & 0.111 & 0.000 \\
\hline \hline
\end{tabular}

\subsection{EL USO DE LA INFORMACIÓN PALEOBOTÁNICA EN LOS MODELOS DE DISTRIBUCIÓN DE ESPECIES.}

El fuerte desarrollo de bases de datos públicas y globales de los últimos años ha aumentado y facilitado la disponibilidad de datos de biodiversidad a nivel global, provocando su creciente uso para resolver preguntas macroecológicas, biogeográficas y filogeográficas (Elith y Leathwick, 2009 y Peterson et al., 2010). En particular, el aumento rápido del acceso a datos fósiles está ampliando nuestro conocimiento sobre el funcionamiento de los ecosistemas a largo plazo (Willis et al., 2010). Los datos paleoecológicos proporcionan gran cantidad de datos sobre la presencia pasada de las especies y comunidades en escalas de miles de años resultando cruciales para entender la respuesta de la biodiversidad frente a los cambios ambientales. En la última década, la disponibilidad de modelos de circulación globales que simulan las condiciones climáticas del pasado junto con los datos paleoecológicos ha favorecido su uso en la modelización de distribución especies (Maguire et al., 2015).

Los MDE se han combinado con datos paleoecológicos para, entre otros, estudiar las respuestas de las especies frente a cambios climáticos (Nogués-Bravo et al., 2008), explorar la extinción de especies (Lorenzen et al., 2011), estudiar la conservación del nicho de las especies a lo largo del tiempo (Stigall, 2012), estudiar los mecanismos de diversificación de 
las especies o de especiación (Peterson y Nyári, 2008), identificar áreas habitables para los humanos durante el Último Máximo Glacial (Banks et al., 2008) y como fuente independiente de datos para contrastar la robustez de las predicciones de especies en el pasado (Roberts et al., 2012a, b y Williams et al., 2013b). La fiabilidad de las predicciones de los MDE a escalas de miles de años no se puede demostrar a menos que se utilicen registros fósiles para verificar las predicciones de los modelos (Martínez-Meyer et al., 2004 y Rodríguez-Sánchez et al., 2010). Los datos paleobotánicos constituyen información objetiva de la composición de la vegetación que existió en un lugar y momento determinado. Por tanto, constituyen una fuente muy valiosa de datos independientes que permiten validar las predicciones de los modelos (Pearman et al., 2008). En los últimos años se ha incrementado el número de estudios que incorporan información paleobotánica en los modelos proyectados al pasado que demuestran el gran potencial que tiene la combinación de los MDE con estos datos (p.e. Alba-Sánchez et al., 2010 y Maiorano et al., 2013).

Sin embargo, los datos paleoecológicos, contrariamente a los datos actuales, presentan algunas limitaciones ya que tienen asociada una incertidumbre temporal y espacial (Brewer et al., 2012) que podrían limitar las interpretaciones ecológicas de los modelos que utilicen estos datos. Varios artículos han discutido las perspectivas y limitaciones relacionadas con el uso de los MDE para enfrentar preguntas filogeográficas, biogeográficas y macroecológicas a largo plazo (Franklin et al., 2015, Nogués-Bravo et al., 2009, Svenning et al., 2011 y Varela et al., 2011) pero no las limitaciones concretas de los datos paleobotánicos.

Los datos paleobotánicos se utilizan en los MDE para calibrar los modelos bajo condiciones climáticas pasadas (p.e. Martínez-Meyer y Peterson, 2006) o para validar las predicciones de los modelos generados en el presente y proyectados al pasado (hindcasting) (p.e. Record et al., 2013). Generalmente los datos paleobotánicos incluidos en estos análisis son registros polínicos (p.e. De Lima et al., 2014) debido a su mayor disponibilidad en los períodos de tiempo más utilizados en las simulaciones de clima pasado (6000 y 21000 años cal BP). Los datos de polen fósil en MDE se usan como indicador directo de presencia de la especie en el pasado, lo que implica una serie de asunciones, como la correspondencia entre el registro fósil y las especies y su abundancia en el espectro original, que no siempre son ciertas (Behrensmeyer et al., 2000). El tamaño de los restos y su resistencia a la descomposición y la idoneidad de los depósitos sedimentarios para conservar material orgánico (temperatura, $\mathrm{pH}$ y falta de oxígeno) limitan el proceso de fosilización. Asimismo los procesos tafonómicos (incluyendo la producción, el transporte y su deposición) limitan la correspondencia entre el 
registro fósil y la vegetación en el pasado (Goring et al., 2013). Por ello, el registro fósil está sesgado hacia determinados taxones, períodos de tiempo y sitios que contienen aquellas condiciones favorables para su preservación (Behrensmeyer et al., 2000 y Varela et al., 2011).

La acumulación de los granos de polen en los sedimentos permite la obtención de datos cuantitativos y cualitativos de los tipos polínicos a diferentes profundidades en la columna sedimentaria. Por tanto, el polen permite hacer reconstrucciones secuenciales en el tiempo ya que se deposita de forma continua en los distintos niveles de sedimentos (Fægri y Iversen, 1950). Los sondeos polínicos cubren un área de influencia muy grande $\left(10^{3}-10^{4} \mathrm{~km}^{2}\right)$ con lo que pueden recoger información de la vegetación a nivel regional y no sólo información de la vegetación más cercana (Conedera et al., 2006 y Hellman et al., 2007). Además, las diferencias en la producción, dispersión, deposición, preservación del polen y su manipulación en laboratorio implican precaución en la interpretación de la representatividad de las especies en los diagramas polínicos (Birks y Birks, 2000 y Goring et al., 2013). Generalmente, los taxones cuyo polen es dispersado por insectos (entomófilas) tendrán menor presencia en los diagramas polínicos que aquellos que dispersan el polen por el viento (anemófilas) ya que producen menos cantidad de polen (Prentice, 1988). Además los granos de polen de los taxones no-anemófilos generalmente tienen menos capacidad dispersiva comparados con los taxones anemófilos como resultado de su diferente tamaño, peso y morfología (Erdtman et al., 1969). Por último, hay que considerar que generalmente en los registros polínicos los árboles y arbustos se identifican a nivel de género y las herbáceas a nivel de familia.

Los macrofósiles y megafósiles aportan información complementaria a los taxones registrados en el polen aunque son menos frecuentes, sus dataciones son puntuales en el tiempo y por tanto son menos usados en los estudios de MDE que el polen (p.e. Alsos et al., 2009). Sin embargo, son considerados como indicadores de presencia local (incluso puntual en el caso de troncos en posición de vida, p.e. García-Amorena et al., 2007, 2008) encontrándose por lo general cerca de la fuente de producción (Birks y Birks, 2000). Por otro lado, los macrofósiles pueden proporcionar información sobre la presencia de taxones no representados en los diagramas polínicos, por pertenecer a taxones con una baja producción polínica o en un periodo independiente del reproductivo (p.e. madera, hojas, corteza), que por ejemplo evidencien la presencia de individuos demasiado jóvenes o cuyo clima es desfavorable para su floración (Hicks, 2006). Asimismo, la resolución taxonómica que 
proporcionan los macrorrestos suele ser mayor que la alcanzada en los análisis polínicos, llegando incluso al nivel de grupo o especie (Birks y Birks, 2000 y Schweingruber, 1990).

Aunque la interpretación de las limitaciones e información proporcionada por los diferentes tipos de datos paleobotánicos constituye probablemente el principal factor limitante de la utilización de estos datos en MDE, generalmente no se aborda en las publicaciones de modelización que usan estos datos. Algunos ejemplos de la interpretación errónea de los resultados al incorporar estos datos en los modelos son: i) la asunción de que la no presencia de una especie es evidencia de su ausencia cuando puede deberse a la ausencia de las condiciones necesarias para su preservación, ii) el sesgo al extrapolar las condiciones ambientales donde se han preservado los taxones como zonas idóneas para los mismos en el pasado cuando son zonas con unas características muy concretas (p.e. turberas, zonas de gran húmedad o áreas montañosas) que pueden ser adecuadas para su preservación pero no constituir una representación uniforme del territorio, iii) el sesgo en la distribución de datos en las bases de datos globales que no reflejan los patrones de densidad real de datos existentes, iv) la generación de modelos para un determinado grupo taxonómico mezclando taxones de diferente categoría y con nichos ecológicos diferentes que puede conducir a una sobreestimación de los límites ambientales de los taxones (p.e. Pinus L., Ulmus L. y Quercus L. en Williams et al., 2013a).

Consecuentemente la comprensión de las limitaciones y el sesgo del registro fósil ayudarán a mejorar su uso en MDE para realizar un análisis fiable de las hipótesis. Los usuarios de MDE deben ser conscientes de las limitaciones de los diferentes informadores paleobotánicos en cuanto a la representatividad de los datos, taxonomía, cronología, fuentes de datos y su distribución espacial para mejorar las interpretaciones ecológicas de los análisis en los MDE en el pasado.

\subsection{INFLUENCIA DE LA COMPLEJIDAD DE LOS MODELOS DE DISTRIBUCIÓN DE ESPECIES EN SU TRANSFERIBILIDAD TEMPORAL}

La complejidad del modelo, definida como el número de parámetros incluidos en el modelo, afecta a la incertidumbre de los modelos y su transferibilidad a través del espacio y el tiempo (Warren et al., 2014). La complejidad de modelo influye en la estimación de la calidad del hábitat y la amplitud del nicho de la especie y a su vez puede afectar negativamente a la capacidad predictiva del modelo, como resultado del sobreajuste del modelo a los datos de calibración (Warren y Seifert, 2011). Los modelos excesivamente complejos pueden conducir 
a una sobre- o infra-predicción de la distribución de la especie (Cao et al., 2013) y reducir la transferibilidad de los modelos en el tiempo (Warren y Seifert, 2011). A pesar de que varios estudios recientes han evaluado los efectos de la complejidad en el desempeño de los MDE (p.e. Merow et al., 2014, Muscarella et al., 2014, Syfert et al., 2013 y Warren y Seifert, 2011), sólo un estudio ha explorado la incertidumbre asociada a la complejidad de los MDE en las proyecciones futuros bajo escenarios de cambio climático (Warren et al., 2014).

De los diferentes algoritmos de modelización, Maxent es uno de los más usados para proyectar los MDE bajo diferentes periodos temporales (Elith y Leathwick, 2009). Maxent ha sido descrito como un método capaz de ajustar curvas de respuesta excesivamente complejas (Elith y Leathwick, 2009), especialmente cuando se utilizan los ajustes predeterminados (parámetros definidos por defecto por los autores del algoritmo) (Merow et al., 2013). Estos ajustes se han establecido en base a un rango amplio de especies y de condiciones ambientales (Phillips y Dudík, 2008), pero no han sido evaluados en relación con su transferibilidad temporal.

La complejidad de los modelos de Maxent se puede ajustar a través de la elección de: 1) el número de predictores o variables ambientales, 2) las features o curvas de respuesta permitidas, y 3) la regularización seleccionada en el modelo ( $\beta$-multiplier).

Se ha demostrado que la selección inicial del número de variables ambientales que describen el nicho ecológico de la especie tiene una gran influencia en el modelo (Harris et al., 2013 y Synes y Osborne, 2011). En general, esta selección se basa en el conocimiento previo de la ecología de las especies y en análisis estadísticos (Morueta-Holme et al., 2010).

Maxent construye un modelo empezando por una distribución uniforme de los valores de probabilidad en todos los datos (puntos de presencia y background) y luego realiza un proceso iterativo que mejora el ajuste del modelo seleccionando las "features" que mejor explican la distribución de la especie (Merow et al., 2013). Las features son funciones y otras transformaciones de las variables ambientales (linear, quadratic, product, threshold y hinge; Phillips y Dudík, 2008) que pueden ser seleccionadas manualmente por el usuario (Phillips y Dudík, 2008), o automáticamente por el algoritmo cuando se utiliza la opción "autofeatures". Las "linear features" usan coeficientes lineales de transformación para cada variable predictora, las "quadratic features" usan valores cuadrados de las variables, las "product features" permiten interacciones entre variables, las "threshold features" permiten introducir 
el uso de umbrales en las variables y por último, las "hinge features" combinan las funciones "linear" y "threshold” (Phillips y Dudík, 2008).

Finalmente, dado un número de variables ambientales y habiendo seleccionado las features permitidas en el modelo, Maxent controla la complejidad del modelo a través del parámetro de regularización ( $\beta$-multiplier). Maxent fuerza a que coincidan los valores predichos de las medias y varianzas de las variables con los valores de las presencias de la especie. De este modo, el parámetro de regularización previene que los modelos estén sobreajustados asegurando que los valores predichos no se ajustan completamente a los valores empíricos de las variables predictoras (Merow et al., 2013). Asimismo el parámetro de regularización limita el número de features incluidas en el modelo basándose en el número de presencias, un mayor número de presencias permite el uso de más features (Merow et al., 2013). Valores altos del parámetro de regularización penalizan la inclusión de parámetros en el modelo creando modelos menos complejos que los generados por defecto (regularization parameter $=1$ ).

A pesar de que Maxent permite controlar la complejidad del modelo mediante la modificación de las opciones configuradas por defecto (Phillips et al, 2006), en la mayoría de los estudios que utilizan este algoritmo, complejidad del modelo y su influencia en los resultados se suele ignorar por completo (Muscarella et al, 2014, Warren et al., 2014 y Yackulic et al., 2013).

\subsection{INFLUENCIA DE LOS DATOS DE ENTRADA (DATOS DE PRESENCIA Y DATOS} CLIMÁTICOS) EN EL PROCESO DE MODELIZACIÓN Y EN LAS PREDICCIONES FUTURAS DE LOS MODELOS.

A pesar de que algunos estudios han demostrado la influencia de la variabilidad intraespecífica en la predicción de la distribución de las especies frente al cambio climático (Benito-Garzón et al., 2011 y Valladares et al., 2014), generalmente se recomienda que los MDE se generen para todo el rango ambiental de la especie (Hijmans y Elith, 2013). Como los MDE asumen que la especie se encuentra en equilibrio con el clima (Mateo et al., 2011), al modelizar la especie en su totalidad, incluyendo poblaciones que posiblemente no estén en equilibrio con el clima, se puede sobreestimar la potencialidad de una especie en el territorio y subestimar su riesgo de extinción en estudios de cambio climático.

El estudio del efecto de la incorporación de las poblaciones marginales en los MDE, cuya persistencia puede deberse a su resiliencia, a su gran longevidad, o a la existencia de microclimas, ha evidenciado que se obtienen diferentes resultados cuando se modelizan las 
poblaciones individualmente frente al rango total de la especie (p.e. Fernández et al, 2015, Soley-Guardia et al., 2016, Vale et al., 2014 y Williams-Tripp et al., 2012). Estos estudios indican que las especies responden de manera diferente a los cambios climáticos a lo largo de su distribución.

Los MDE predicen con eficacia la distribución potencial de las especies incluso con pocas presencias (Hernandez et al, 2006 y Shcheglovitova y Anderson, 2013) y con datos de presencias sesgados o incompletos (Newbold, 2010). Algunos trabajos defienden la generación de modelos sin los datos marginales alegando que estos datos sobreestiman el nicho de una especie ya que son presencias fuera de las condiciones habituales de la especie (Soley-Guardia et al., 2016). Otros, en cambio, modelizan las poblaciones marginales y la población total de la especie por separado para identificar las áreas idóneas para las poblaciones marginales que no se observan en los modelos totales para toda la especie (Fernández et al, 2015 and Vale et al., 2014). Sin embargo, el efecto de la predicción de los MDE cuando las poblaciones marginales de una especie tienen muy pocas presencias en comparación con el resto de poblaciones continúa poco estudiado, especialmente en estudios de evaluación de los impactos del cambio climático.

\subsection{EL USO DE LA IMÁGENES DE SATÉLITE EN LOS MODELOS DE DISTRIBUCIÓN DE ESPECIES}

La teledetección es la técnica que permite obtener información a distancia de objetos sin necesidad de contacto material con ellos (Chuvieco, 1996). La imagen de satélite es una representación visual de los datos observados desde un satélite artificial que es posteriormente enviada a una estación donde es procesada y convertida en imágenes. Generalmente, los datos derivados de las imágenes de satélite se utilizan para generar variables predictoras que se incorporan a los MDE para mejorar la predicción espacial de los modelos o para predecir la riqueza de especies de un área (Cord et al., 2014 y Zimmermann et al., 2007).

Otra de las aplicaciones de la teledetección es la elaboración de mapas de vegetación (Jennings, 2000, Kerr y Ostrovsky, 2003 y Saveraid et al., 2001) mediante la clasificación de imágenes digitales. Estos mapas generados a partir de las imágenes de satélite pueden servir por ejemplo, para estudiar la fragmentación y la conectividad de las masas forestales. Asimismo pueden servir para estudiar cambios en la cubierta vegetal o cambios de uso de suelo mediante la comparación de imágenes de satélite en distintos periodos de tiempo. De igual modo, los mapas de vegetación sirven como fuente de datos independientes para la 
validación de los MDE pero sólo en el caso de que una especie represente una clase de vegetación o cuando se modelicen varias especies correspondientes a una clase de vegetación. Esto es debido a que las imágenes de satélite generan mapas de tipos forestales y raramente pueden distinguir especies a nivel individual (Bradley y Fleishman, 2008). 


\section{8 OBJETIVOS}

El objetivo de esta tesis doctoral es mejorar la transferibilidad temporal y espacial de los modelos de distribución de especies reduciendo la incertidumbre de los mismos. Para ello se plantea el estudio de la influencia de diferentes factores en el proceso de modelización con el algoritmo Maxent y el uso de datos paleobotánicos y de imágenes de satélite como herramientas de validación de los modelos generados.

Para conseguir el objetivo general, se proponen los siguientes objetivos específicos:

i) Analizar el potencial y las limitaciones del uso de los datos paleobotánicos en el proceso de calibración y validación de los modelos distribución de especies (Capítulo 2).

ii) Estudiar la influencia de la complejidad de los modelos y del tipo de validación con datos paleobotánicos en el proceso de modelización y en la transferibilidad temporal de los modelos. Este objetivo se aborda mediante el estudio de caso de Alnus glutinosa (L.) Gaertn. y Corylus avellana L. en la Península Ibérica en el presente y en el Holoceno medio (6000 años cal BP) (Capítulo 3; Anexo I).

iii) Analizar la influencia de los datos de entrada (datos de presencia y datos climáticos) en el proceso de modelización, en la transferibilidad espacial y en las predicciones futuras de los modelos en el estudio del impacto del cambio climático. Este objetivo se plantea mediante el estudio de caso de Pinus uncinata Ramond ex DC. in Lam. \& DC. en la Península Ibérica, enfocado a sus poblaciones marginales y el efecto de distintas definiciones de su hábitat ambiental (Capítulo 4).

iv) Validar los modelos de distribución potencial de especies con mapas de vegetación obtenidos a partir de imágenes de satélite.

v) Analizar el efecto de la selección del umbral en las predicciones futuras de los modelos.

Estos dos últimos objetivos se abordan mediante el estudio de caso de Pinus hartwegii Lindl. en el parque nacional Izta-Popo (México), y el estudio de su vulnerabilidad frente a diferentes escenarios de cambio climático (Capítulo 5). 


\section{POTENCIAL Y LIMITACIONES DEL USO DE DATOS PALEOBOTÁNICOS EN TRABAJOS DE MODELOS DE DISTRIBUCIÓN DE ESPECIES.}

Este capítulo reproduce íntegramente el manuscrito enviado a Palaeogeography, Palaeoclimatology, Palaeoecology:

Moreno-Amat, E., Rubiales, J.M., Morales-Molino, C., García-Amorena, I. Incorporating plant fossil data into palaeo-SDMs is not straightforward: pitfalls and possible solutions.

\subsection{RESUMEN}

El creciente desarrollo del uso de datos paleoecológicos en los modelos de distribución de especies (MDE) ha generado nuevos enfoques para responder preguntas sobre evolución, ecología y biogeografía. La incorporación de datos paleobotánicos en los MDE ha permitido, por ejemplo, construir los modelos con el clima y presencias del pasado o validar los modelos calibrados con el clima y presencias actuales y proyectados bajo condiciones climáticas del pasado. Los datos paleobotánicos proporcionan información muy útil sobre la distribución pasada de los taxones en un periodo temporal y un lugar determinados y contribuyen al avance de los MDE. Sin embargo, estos datos también poseen ciertas limitaciones al ser usados en los MDE que pueden dificultar las interpretaciones ecológicas de los resultados y conducir a conclusiones erróneas. Los datos paleobotánicos generalmente no son equivalentes a los datos actuales sino que con frecuencia presentan limitaciones y sesgos en relación con la representatividad y la taxonomía de las especies y el control cronológico. Por ello, su incorporación en los estudios de MDE debe ser realizada cuidadosamente. La falta de conocimiento de las limitaciones de los datos paleobotánicos y su interpretación constituyen probablemente el principal escollo de la utilización de estos datos en los trabajos de MDE. No obstante, rara vez se discuten las limitaciones de este tipo de datos en estas publicaciones. En este trabajo se defiende el control y una selección cuidadosa de los datos paleobotánicos para mejorar la robustez, la fiabilidad y la significación de los análisis de paleomodelización.

Palabras clave: polen fósil, proyección al pasado, calibración de modelos, modelización, validación de modelos, bases de datos paleobótanicas, paleo-modelos de distribución de especies, macrofósiles vegetales.

\subsection{ABSTRACT}

The increasing development of species distribution models (SDMs) using palaeodata has created new perspectives to address questions of evolution, ecology and biogeography. The 
incorporation of palaeobotanical data has allowed, for example, to calibrate models under past climate conditions or to validate projected models calibrated on current species distributions. Palaeobotanical data provide useful information on the past distribution of taxa at a given time and place and contribute to advancing the SDM field. However, these data also possess certain shortcomings when used in SDMs and may hinder the resulting ecological outcomes and eventually lead to wrong conclusions. Palaeodata may not be equivalent to present data, but instead frequently exhibit limitations and biases regarding species representativity, taxonomy and chronological control, and their inclusion in SDMs should be carefully assessed. The limitations of palaeobotanical data applied to SDM studies are infrequently discussed and often neglected in the modelling literature; thus, we argue for the more careful selection and control of these data to improve the robustness, reliability and significance of palaeo-SDM analyses.

Key-words: fossil pollen, hindcasting, model calibration, modelling, model validation, palaeo-database, palaeo-species distribution models, plant macrofossils.

\subsection{INTRODUCTION}

The development of global databases has increased the availability of biodiversity data at the planetary scale and triggered rapid progress in the use of biodiversity informatics to resolve a wide spectrum of macroecological, biogeographical and evolutionary questions (Elith and Leathwick, 2009 and Peterson et al., 2010). Following this trend, the rapid and steady increase in accessible fossil data is broadening our knowledge on the functioning of ecosystems over long timescales (Willis et al., 2010). The palaeorecord provides a unique and large body of data documenting the past occurrence of species and communities at decadal to millennial timescales, and is crucial to extend our understanding of the response of biodiversity to environmental changes. The coupled use of palaeodata and computing tools is an emerging discipline (Brewer et al., 2012). In this context, correlative species distribution models (SDMs) (i.e., algorithms that relate species occurrences to environmental and geographical predictors; Guisan and Zimmermann, 2000) have attracted increasing attention (Maguire et al., 2015). Specifically, SDMs are extensively used to study nature conservation (e.g. Anderson and Martínez-Meyer, 2004) and management (e.g. Schwartz, 2012), climate change impacts (e.g. Thuiller et al., 2005) and invasive species (e.g. Ficetola et al., 2007), among others. 
SDMs have also been applied to past environments to locate potential migratory routes (Waltari and Guralnick, 2009), study range dynamics and taxa responses to climate change (Nogués-Bravo et al., 2008), integrate the spatial distribution of species and genetic diversity (Espíndola et al., 2012), explore species extinctions (Lorenzen et al., 2011), test species niche conservatism over time (Stigall, 2012), examine species diversification or speciation mechanisms (Peterson and Nyári, 2008), correlate species richness and climatic change (Sandel et al., 2011) and identify habitable areas for humans during the Last Glacial Maximum (Banks et al., 2008).

Palaeoecological data have recently been applied to assess the robustness of SDM predictions of past time periods (e.g. Roberts and Hamann, 2012a, b). The predictive accuracy of SDMs is generally defined as the ability of the model to correctly classify the presence and absence of species. To assess their performance, model predictions are validated by dividing the original dataset into two subsets, with one for model training and the other for model validation, using data independent from the data used in the model fitting or using data from different regions (Araújo et al., 2005). However, the reliability of SDM predictions at millennial scales cannot be demonstrated unless fossil records are used to verify the model predictions (Martínez-Meyer et al., 2004 and Rodríguez-Sánchez et al., 2010).

A number of reviews have discussed the achievements, limitations and prospects related to the use of SDMs to address phylogeographical, biogeographical, and macroecological research questions over long timescales. Nogués-Bravo (2009) noted the theoretical assumptions underlying niche modelling that may influence the resulting inferences and provided suggestions to improve hindcasting. Several sources of uncertainty when predicting palaeodistributions (such as atmosphere-ocean global circulation models) were explored by Collevatti et al. (2013), who proposed a framework coupling palaeoclimatic distributions, the fossil pollen record and phylogeographical studies. Franklin et al. (2015) reviewed SDM studies that hindcast palaeodistributions of plants and animals and demanded their use to reconstruct resource palaeolandscapes to improve the understanding of human prehistory. Both Varela et al. (2011) and Svenning et al. (2011) focused on methodological and conceptual issues (data, predictors and modelling algorithms) of palaeo-SDMs coupled with palaeobiological data. Finally, Maguire et al. (2015) highlighted the importance of palaeodata to test the predictive ability of SDMs and their assumptions with an emphasis on the potential of community-level models. 
In this paper, we focus on the use of palaeobotanical data in SDMs because this type of data is well suited to exploring the limitations inherent in the use of fossil data in SDMs and analysing the differences with modern datasets. In addition to the temporal and spatial uncertainties (Brewer et al., 2012), palaeobotanical data share certain features with other palaeobiological records whose limitations have been previously discussed by Varela et al. (2011). Nevertheless, additional factors that may hinder the validity and reliability of SDM interpretations must be considered, including the processing of palaeobotanical information from different sources, which likely constitutes the main obstacle to successfully using these data in SDMs, although it has been rarely addressed in the literature.

Here, we discuss the constraints on the use of palaeobotanical data in SDM studies by focusing on problems observed in published papers. We will discuss the assumptions and limitations related to the use of palaeobotanical data in SDM studies, assess the use of this type of data in the SDM field up to the present, and then conclude by providing suggestions to improve the use of palaeodata for modelling purposes.

\subsection{PALAEOBOTANICAL CONSTRAINTS FOR SDMS}

Palaeobotanical data included in SDM analyses are generally used as a direct proxy for past species occurrences, which involves a number of underlying assumptions that do not always hold true, such as the lack of correspondence between fossil assemblages and the species spectra and abundance of the original living assemblages (Behrensmeyer et al., 2000). The size and resistance to decay of the remains and the suitability of sedimentary deposits for preserving organic material (i.e., temperature, $\mathrm{pH}$, and lack of oxygen) constrains the fossilization process. Hence, the fossil record is biased towards certain taxa, time periods and sites that hosted favourable conditions for fossil preservation (Behrensmeyer et al., 2000 and Varela et al., 2011).

Additionally, the taxonomic resolution reached in the analysis (usually lower in pollen than in macrofossil assemblages) and taphonomic processes (including production, transport, and deposition) limit the correspondence between fossil assemblages and past vegetation (Goring et al., 2013), thus limiting the usefulness of fossil data. Additionally, the chronology of the fossil record must be accurate and precise for the data to be fully valuable and to allow for comparisons with other independent data, and these conditions also apply when fossil records are correlated with modelled past climates. These climatic models are simulated for particular time periods, and SDMs consequently require palaeobotanical data within the same time 
period. A suitable chronology consists of a sufficient number of absolute dates, robust age estimates for control points, and appropriate age-depth models when using fossil data in SDMs.

SDM users should be aware of the limitations of the different palaeobotanical proxies with respect to the data's representativity, taxonomy, chronology, data density, data source and spatial distribution to improve the ecological interpretations of the analysis.

\subsubsection{Species representation}

Fossil pollen is the most important source of data in articles that use palaeobotanical information in SDMs (see Table 2.1). Pollen is continuously deposited in sedimentary environments, and constant taphonomic regimes allow for sequential reconstructions of vegetation over time (Fægri and Iversen, 1950). Terrestrial pollen records may represent vegetation over a large area $\left(10^{3}-10^{4} \mathrm{~km}^{2}\right)$; therefore, collected information should be considered at local to regional scales (Conedera et al., 2006 and Hellman et al., 2008). Moreover, the representation of different taxa in pollen records may be biased by differences in pollen production, dispersion, deposition, preservation and manipulation (Birks and Birks, 2000 and Goring et al., 2013). In general terms, entomophilous and ambophilous taxa are underrepresented (e.g. Acer L. and Aesculus L.) compared with anemophilous taxa (e.g. Pinus L., Betula L., Fagus L.) (Prentice, 1988) because of their relatively low pollen production. Additionally, non-anemophilous taxa generally produce pollen grains that present reduced dispersal compared with anemophilous taxa as a result of the size, weight and morphology of the pollen grain (Erdtman et al., 1969). For instance, the differences in the representation of Tilia L. and Quercus L. in lake sediments are explained by the poor dispersal ability of the relatively heavy and large pollen grains of Tilia as well by its lower pollen production (Prentice, 1988). Important dissimilarities in dispersal capacity are observed even within anemophilous taxa, such as between Abies alba Mill. and other co-occurring tree species, such as Fagus sylvatica L. and Pinus sylvestris L. (Poska and Pidek, 2010), and within taxa among different localities (Pidek et al., 2013).

Differences in pollen morphology affect pollen transportation distances. Bisaccate pollen grains, such as Pinus, can be transported long distances by the wind (Erdtman et al., 1969), although the observance of certain exceptions in the fossil record, such as Abies Mill., whose large pollen size limits long-distance dispersal, indicates proximity to the pollen source (Erdtman et al., 1969). Finally, there may be additional biases in pollen analysis associated 
with laboratory treatments, particularly for large-sized pollen types (e.g. Abies; 150-160 $\mu \mathrm{m}$; Beug, 2004) that may not be retained during the sieving process if the mesh size is too small such as the mesh recommended in several reference protocols for pollen sample processing (e.g. $180 \mu \mathrm{m}$ in Bennett and Willis (2001) and 100-120 $\mu \mathrm{m}$ in Moore et al. (1991)). In addition, fragile pollen can be damaged during chemical treatments (Hicks, 2006).

The common method of identifying the presence of a species from pollen is by defining a threshold in its relative pollen representation, i.e., a percentage in relation to the sum of the terrestrial plant pollen. The selection of the threshold that indicates a local/regional presence for a certain species is a crucial although problematic factor for many reasons. The most important limitation is related to the strong variation of thresholds among species, regions (Lisitsyna et al., 2011), and forest covers (Baker et al., 2016); moreover, "no pollen does not mean no trees" (Hicks, 2006). Furthermore, the pollen percentage does not consider variations in the amount of pollen through time, which leads to a distortion of the true pollen abundance (measured by accumulation rates) for each pollen type. Additionally, when pollen is scarce, changes are strongly magnified (Davis and Deevey, 1964). Thus, using pollen percentages as indicators of species presence/absence is not straightforward (Hicks, 2006). Because different patterns of plant abundance can produce the same pollen percentage assemblages (Prentice, 1988), defining the presence or absence of a species in an area from pollen assemblages is a critical point that should be carefully assessed. Pollen-vegetation relationships are mainly studied by analysing the pollen rain collected through pollen traps and surface samples (e.g. mosses or soil) and comparing the samples with the surrounding vegetation (e.g. Hicks, 2007 and Sugita, 2007a, b). Because the resulting models have primarily been validated in boreal and temperate ecosystems (e.g. Scandinavia and Central Europe; Sugita, 2007a, b), the behaviour of these models remains largely unknown for other biomes (e.g. Mediterranean or tropical). Pollen productivity is particularly influenced by temperature (Autio and Hicks, 2004), implying that the productivity for a given taxon could vary substantially between areas with varying climates (Broström et al., 2008). These models use Pollen Productivity Estimates (PPEs) of the species as a key input for the model and assume that the PPEs remain constant over time for each taxon in a given vegetation region. PPEs are obtained for each taxon by relating the modern vegetation composition and its proportion in the pollen assemblage (Broström et al., 2008). The differences in the values of PPEs within taxa can be explained by methodological issues (pollen sampling) as well as by the climate, reproductive strategy and species growth form (Broström et al., 2008). For 
example, flowering is heavily limited in certain species growing near their range limits (e.g. Betula and Juniperus L.; Broström et al., 2008) and inside forests rather than in open environments (e.g. Corylus avellana L.) (Baker et al., 2016).

Another approach to defining the presence or absence of a species from pollen assemblages is based on the Pollen Accumulation Rate (PAR). The PAR is an estimate of the number of pollen grains deposited on the sediment surface per year (Davis, 1967 and Seppä et al., 2009). The PAR values of certain pollen types are independent of changes that affect other pollen types and changes in the sedimentation rate, although they are affected by the catchment size, pollen transport and sediment redeposition (Davis, 1967). Hence, PAR values from different records cannot be easily compared (Giesecke and Fontana, 2008). However, despite the potential of PAR values, they are not currently used in SDM studies, which is primarily because the PAR for each pollen type is rarely reported in pollen records and cannot be obtained from published pollen diagrams or pollen public databases.

Nonetheless, the presence of a species in a certain area must be defined to quantify past species distributions or to test distribution hypotheses at the millennial timescale (Szczepanek et al., 2004). However, the approach used to define the presence of past species (pollen percentage threshold, PPE or PAR) is not as important as accounting for the uncertainty associated with the method because the uncertainty influences the SDM output and consensus has not been reached regarding the method that should be applied for each taxon.

Although macrofossils and megafossils are less abundant than pollen, they are considered good indicators of local vegetation because they are usually found near their source (Birks and Birks, 2000). Macrofossils produce a different palaeobiological signal compared with that of pollen because they may represent taxa with low pollen production or poorly preserved pollen. Moreover, macrofossils can be independent from sexual reproductive constraints because wood, leaves and bark can be produced even when flowering is restricted (e.g. young trees or cold environments; Hicks, 2006). Although rare, macrofossils are sometimes preserved sequentially, which provides highly valuable information (Tinner and Kaltenrieder, 2005).

\subsubsection{Taxonomic bias}

The level of detail attained in the taxonomic identification of fossil specimens depends greatly on the type of fossil. Palynologists identify pollen and spores according to 
morphological features that are often shared by several taxa. Hence, in palynological assemblages, trees and shrubs are usually identified to the genus level and herbs are identified to the family level.

Palaeo-SDM studies generally use pollen data as the main source of information; therefore, the selection of target species and study areas is often limited by taxonomic constraints, i.e., pollen types that are unequivocally linked to one single species in a particular area rather than by ecological questions (Varela et al., 2011). This limitation is the main factor that explains the selection of monotypic genera of woody taxa and areas where several species within the same pollen type do not overlap (e.g. Europe in Giesecke et al. (2007), who modelled Fagus sylvatica; and northern and central Europe in Pearman et al. (2008), who modelled Abies alba, Fagus sylvatica, Juniperus communis L., and Picea abies (L.) H. Karst). Taxonomic problems may be overcome by assuming that the taxa included within a pollen type share ecological and/or biogeographical features coherent with the aims of the study. Such assumptions have been made for the close taxa of the western Eurasian Fagus genus (F. orientalis Lipsky, F. sylvatica, F. taurica Popl. and F. moesiaca (K.Malý) Czeczott. However, this simplification frequently produces inaccurate or inconsistent results because at a global scale, diversity among the dominant taxa decreases with increasing latitude. For instance, in northern Europe and the British Isles, there is only one Pinus species ( $P$. sylvestris), whereas in the Mediterranean region, there are up to ten different species (Tutin et al., 1964). Although attempts have been made to discriminate pollen of different Pinus species (e.g. Desprat et al., 2015), Pinus pollen is usually identified only to the genus/subgenus level. This difference in diversity with latitude also applies to other important tree genera, such as Abies, Quercus (Macias-Fauria and Willis, 2013) or Juniperus (Pearman et al., 2008). For instance, Abies alba is the only species of the genus Abies widespread in Europe. Thus, authors studying pollen sites within its range assume that Abies fossil pollen corresponds to Abies alba (Macias-Fauria and Willis, 2013 and Maiorano et al., 2013). However, as shown in Fig. 2.1, the Mediterranean Basin currently hosts 8 species and 3 subspecies of Abies; therefore, the unambiguous correspondence of this pollen type to a single taxon is not easily determined. 


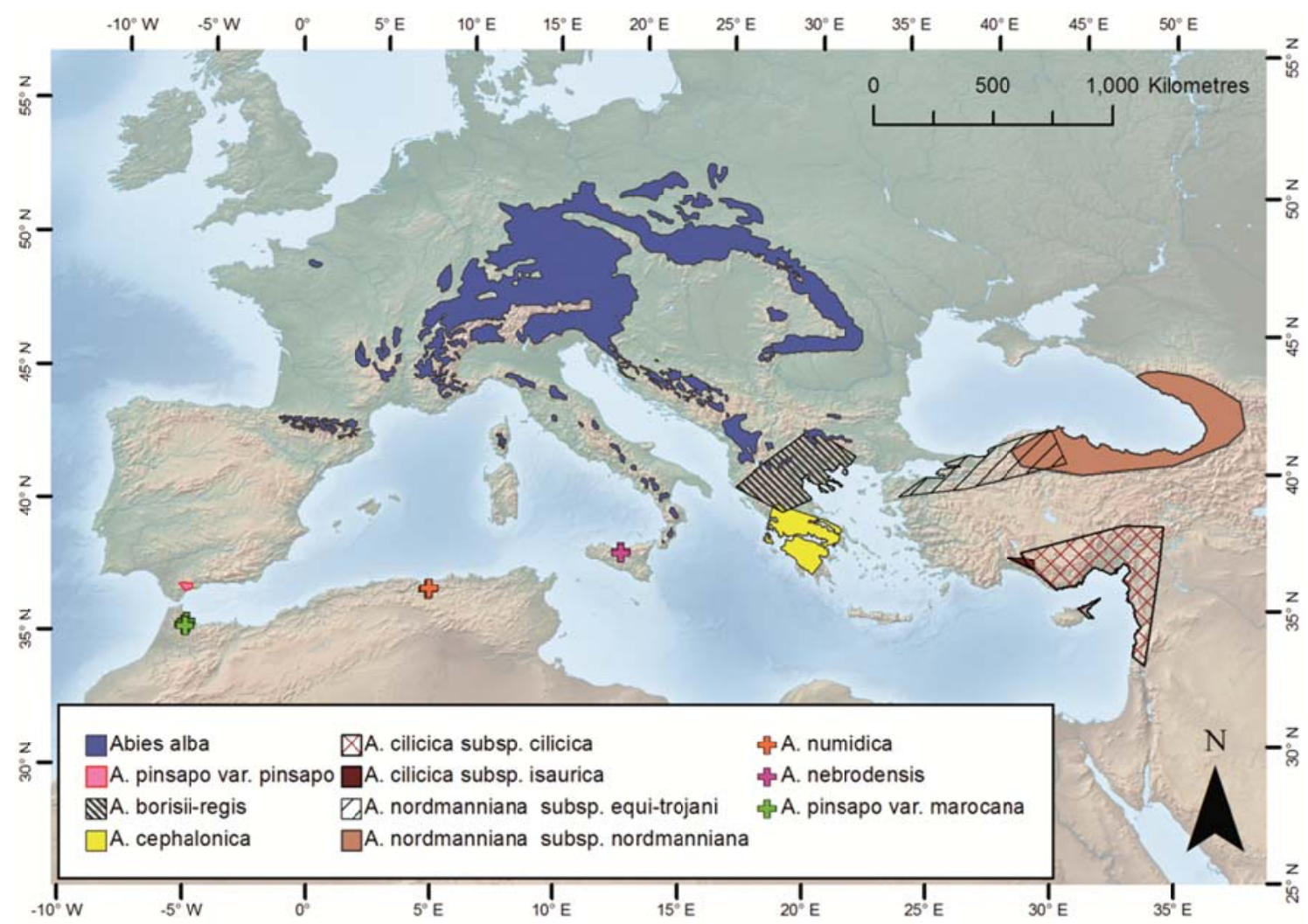

Fig. 2.1. Distribution of the European species of Abies (from Wolf, 2003 and Farjon and Filer, 2013). Although there is a unique widely distributed species in central and northern Europe (Abies alba), at southern latitudes, the taxonomic diversity of the genus is higher. In this case, the correspondence of the same pollen type to a species is far from unambiguous. Aitoff's equal-area map projection is used.

Frequently, general assumptions carry considerable problems related to coherence in taxonomy, including the grouping species with different ecological niches (such as Pinus, Ulmus L. and Quercus in Williams et al., 2013a). As an example, when the past distribution of Quercus ilex L., an endemic oak of the Mediterranean Basin, is modelled, the pollen counts for another evergreen oak, Quercus coccifera L., are also included because these species share the same pollen type (e.g. Macias-Fauria and Willis, 2013). Quercus coccifera is a small tree or shrub that is also endemic to the Mediterranean Basin but markedly more thermophilous and xerophilous than Quercus ilex. Therefore, mixing these two taxa with different ecological niches may lead to inconsistencies in the calibration or validation of past SDMs because the past environmental limits of the species may be overestimated. Similarly, Quercus suber L. is a sclerophyllous oak endemic to the western Mediterranean, and its pollen is indistinguishable from that of Quercus cerris L., a deciduous oak. The distributions of both species overlap in Italy (Magri et al., 2007), where past species inferences that are based on pollen might be misleading. Regardless, these pollen types have been used to assess the performance of SDMs in the past (see Vessella et al., 2015). 
Additional caution should thus be applied in areas with geographical features that have promoted greater speciation or hosted important glacial refugia, such as Mediterranean mountain ranges and islands, because this shift in species diversity within a pollen type is greatly exacerbated.

However, macrofossil studies (Birks and Birks, 2000) may constrain certain palaeoenvironmental inferences because they can often be identified with greater taxonomic accuracy, occasionally to the species level. When this data source is used, more detailed information is obtained (e.g. Alsos et al., 2009), which can reveal the responses of more consistent taxonomical units over long timescales.

\subsubsection{Chronological and temporal biases}

An accurate and precise chronology is crucial when addressing any palaeoecological question because it can be used to assign a date to each event in the fossil record and compare and correlate information from different sites and/or proxies. A set of climatic predictors obtained from General Circulation Models (GCMs) for a series of well-defined time periods, such as the mid-Holocene (6,000 years cal BP) and the Last Glacial Maximum (21,000 years cal BP) (Varela et al., 2015a), are used in palaeo-SDMs. For these two time slices, the most recent relevant plant range expansion (mid-Holocene) and contraction (Last Glacial Maximum) occurred; therefore, these periods played critical roles in the shaping of current plant distributions and genetic diversity.

Focusing on the last 50,000 years, the chronological framework in palaeobotanical research is usually established in two steps: isotopic dating is applied to a series of samples (terrestrial plant macrofossils, peat, and/or bulk sediment) located at different depths along a sedimentary sequence and then the relationship between the depth and calibrated ages is modelled (Blaauw and Heegaard, 2012). When the sample is radiocarbon dated, the resulting age must be calibrated for conversion into the standard calendar year timescale (Bartlein et al., 1995) by calculating the probability distribution of the true age of the sample (Blaauw and Heegard, 2012). The radiocarbon age must be calibrated to reduce differences between the measured radiocarbon age and the real age of the sample caused by changes in the isotopic composition of atmospheric carbon stocks over time. The calibrated age is expressed in years cal BP (Before Present, with the present defined as 1950), years cal BC/AD (before Christ/Anno Domini) or BCE/CE (before the common era/common era). The conversion from radiocarbon years to calibrated calendar years can be performed using consensual calibration 
datasets (IntCal, Marine, and SHCal; Reimer et al., 2013) that are usually coupled with one of the available calibration programs (e.g. Calib [Stuiver and Reimer, 1993], OxCal [Bronk Ramsey, 2009], or Clam [Blaauw, 2010]). For instance, the IntCal13 curve (Reimer et al., 2013) is usually preferred for non-marine radiocarbon samples in the Northern Hemisphere (Stuiver et al., 2005). The accurate correspondence between palaeobotanical data and specific time periods is mandatory for obtaining reliable estimates of past species distributions. Moreover, the same timescale (generally calibrated calendar years BP) must be used for both climatic simulations and fossil data to avoid the introduction of flaws in the SDMs. This consistency must be verified because pollen diagrams can express the age in calendar or radiocarbon years.

Radiocarbon dates and their position in the sequences as well as age-depth models are generally available in databases and publications. However, problems in the chronology of fossil records are frequently identified because of i) insufficient absolute dates, ii) radiocarbon dates that are measured for unsuitable material, iii) uncalibrated radiocarbon dates or iv) the use of unrealistic age-depth models, and these problems result in an unreliable chronological framework (Blois et al., 2011 and Giesecke et al., 2014). Nevertheless, important efforts have recently been made to overcome chronological limitations in the most important fossil plant databases by assessing the reliability of chronologies of pollen records in Neotoma (Blois et al., 2011) and building age-depth models for the available palynological records in the European Pollen Database (Giesecke et al., 2014). Finally, when neither the database nor the original paper provide a depth-age model, SDM users should fit a model to the calibrated radiocarbon dates to locate the target time period in the pollen diagram and then interpolate the pollen percentage of the study species to that specific period (e.g. Blois et al., 2011). A greater number of available radiocarbon dates for a sequence (especially those measured on short-lived terrestrial plant macrofossils) will increase the robustness and precision of the chronology. Blois et al. (2011) and Giesecke et al. (2014) both indicated that it is essential to control the quality of the chronology for the sequences included in these data repositories and update the chronologies with the latest methodological developments in this field when needed.

When macrofossils are analysed along a sedimentary sequence, the chronology is established in the same manner. Intermittent macrofossil findings (e.g. cones, wood, and charcoal) can be directly radiocarbon dated, and their ages can be subsequently calibrated to calendar years. 


\subsubsection{Data characteristics (density, source and spatial distribution of the data)}

Vegetation change studies at large spatial scales can be performed with the use of regional and global databases that compile palaeobotanical information. Public databases share the data freely so that palaeobotanical information can be synthesised and unified across regions, thereby enabling long-term biogeographical and macroecological studies worldwide (Gajewski, 2008). Examples of these databases include the Paleobiology Database (https://paleobiodb.org/), the Neotoma Database (http://www.neotomadb.org/), the European Pollen Database (http://www.europeanpollendatabase.net/) and the Global Pollen Database (https://www.ncdc.noaa.gov/paleo/gpd.html), which is a clustered database. The information in these datasets can be accessed in different ways, including visualization tools, such as in the European Pollen Database, and map explorers, such as in the Neotoma Database, and the data can generally be downloaded as spreadsheet files. Moreover, certain databases can be accessed through the R statistical software (R Core Team, 2015), such as the Neotoma Database and Paleobiology Database, using specific packages (e.g. "neotoma" and "paleobioBD”), which make analysing and plotting fossil data a more straightforward process (Goring et al., 2015, Varela et al., 2015b).

Overall, data density varies among and within continents as a result of differences in sampling efforts, available resources and adequate site availability for plant fossil preservation (Varela et al., 2011). Thus, a bias towards the Northern Hemisphere and higher latitudes can be observed in the amount of pollen and macrofossil records (Fig. 2.2). In drier regions in temperate and tropical areas, lakes and mires are and were much rarer, and the available records are mostly restricted to mountainous areas (with many fragmented records from caves), palaeosols, speleothems in karstic systems, coprolites or marine sediments (e.g. Carrión et al., 2013). 


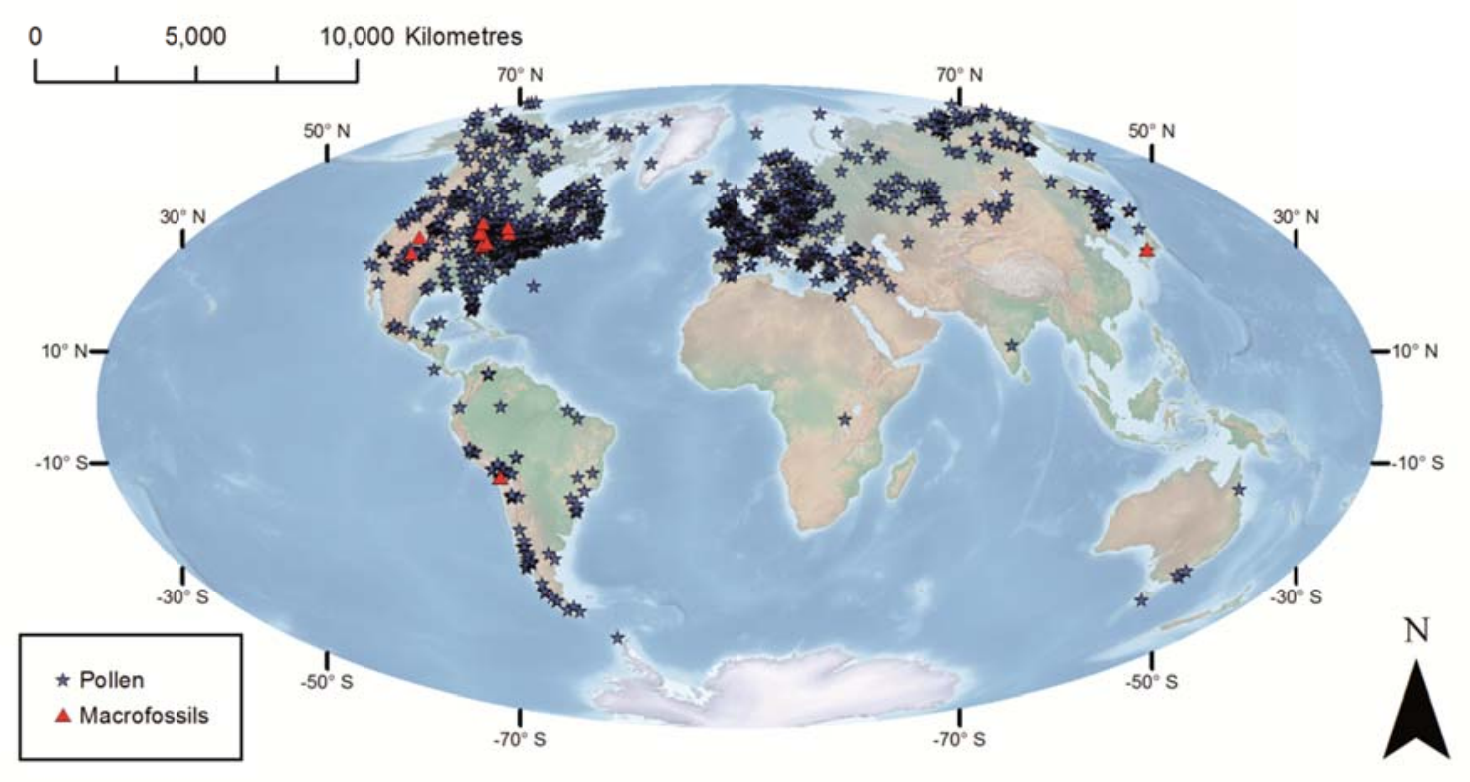

Fig. 2.2. Spatial distribution of the palaeobotanical sites available through the Neotoma Database http://www.neotomadb.org/, accessed September 2014). Aitoff's equal-area map projection is used.

The data included in regional or global datasets do not reflect real data density patterns, which is mostly because the datasets only present data provided by a part of the scientific community (Beck et al., 2014). Large gaps can occur in territories where researchers have not submitted their data to any open access dataset or database maintenance has not been properly conducted. Using the Iberian Peninsula as an example, the review performed by the Paleodiversitas Project (Carrión et al., 2013, http://www.paleodiversitas.org/) shows that of the 340 available palaeobotanical records, only $73(\sim 21 \%)$ can be found in the European Pollen Database and $24(\sim 7 \%)$ can be found in the Neotoma Database (Fig. 2.3). Strong differences in data availability among regions and databases compromise the spatial resolution of the testing hypothesis. In addition, the proportion of macrofossil data in global databases is much lower relative to that of pollen data (see Fig. 2.2 and 2.4). 


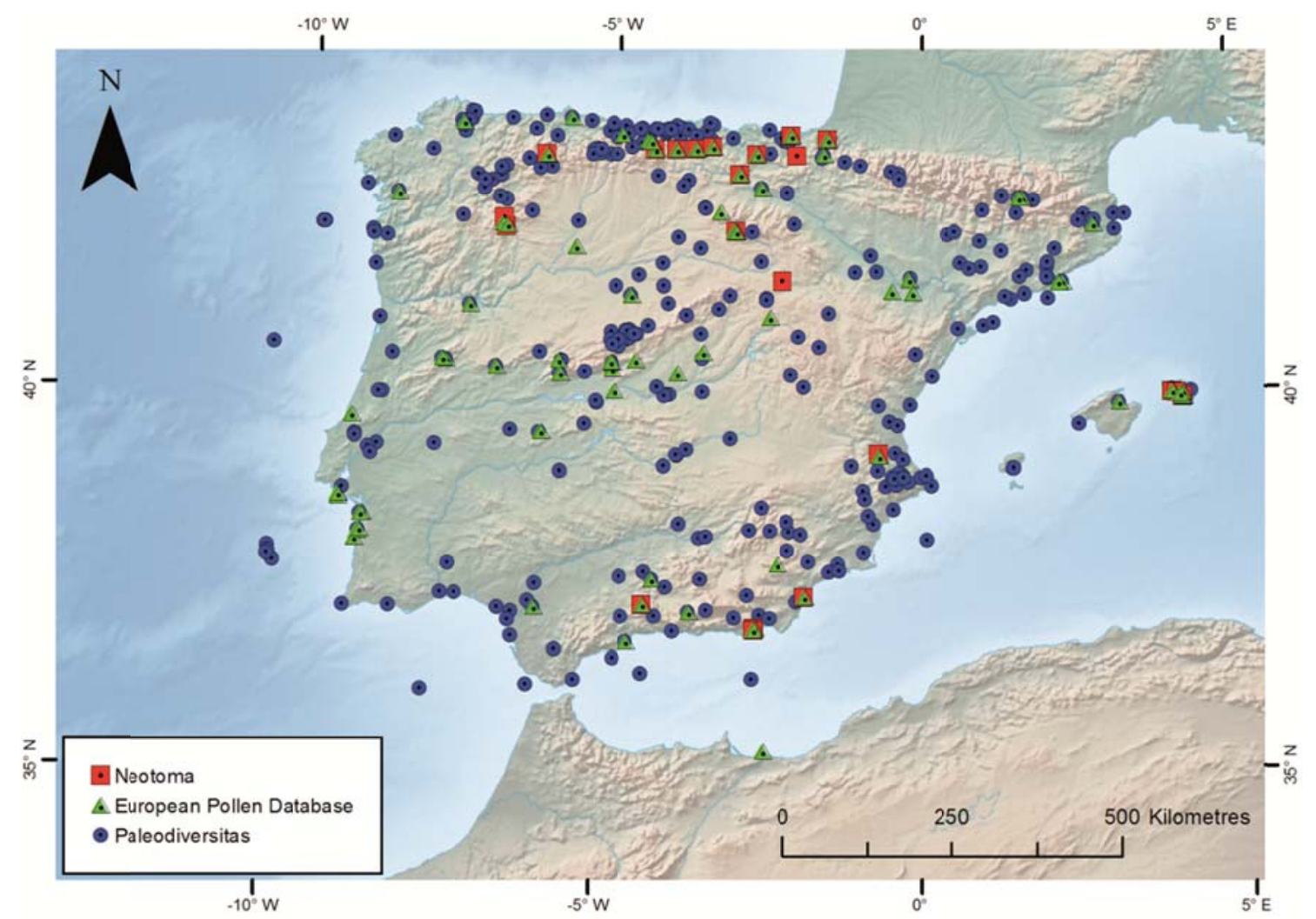

Fig. 2.3. Spatial distribution of palaeobotanical information on the Iberian Peninsula (including Spain, Balearic Islands, Portugal and Andorra) available through the Neotoma Database (red squares; http://www.neotiomadb.org/, accessed September 2014), European Pollen Database (green triangles; http://www.europeanpollendatabase.net/, accessed September 2014) and Paleodiversitas review (blue circles; Carrión et al., 2013). Aitoff's equal-area map projection is used.

The information contained in Paleodiversitas (Carrión et al., 2013) is illustrative of how the information contained in a complete and detailed collection of data is only partially available in global databases when it is published in a book format. Although quantitative data are provided in figures, the format of this compendium increases the difficulty of using the data for further analyses and contributes to issues related to data querying, updating, and administration as well as obtaining pollen percentages and species presence/absence. However, an advisory board supports the consistency of the data as well as the structure and quality of the data in the Neotoma. Although updating a database can be a slow process because of the number of datasets queuing to be incorporated into the database (and not available for public use), this system ensures the careful revision of pollen diagrams, a better selection of sequences with greater chronological quality and consistent taxonomy, and eventually a more solid starting point for the use of past vegetation data for other biogeographical studies (e.g. Williams et al., 2013b).

Therefore, SDM users aiming to couple SDMs and palaeobotanical data at a continental scale must collect and select the data and also analyse the data biases. Large datasets are certainly not complete for certain territories, as shown in the Iberian Peninsula (Fig. 2.3), 
especially for macrofossil availability (Fig. 2.4). Because macro-scale studies have less control over data biases, authors should find a balance between a large quantity of data with low quality and a small quantity of data with higher quality.

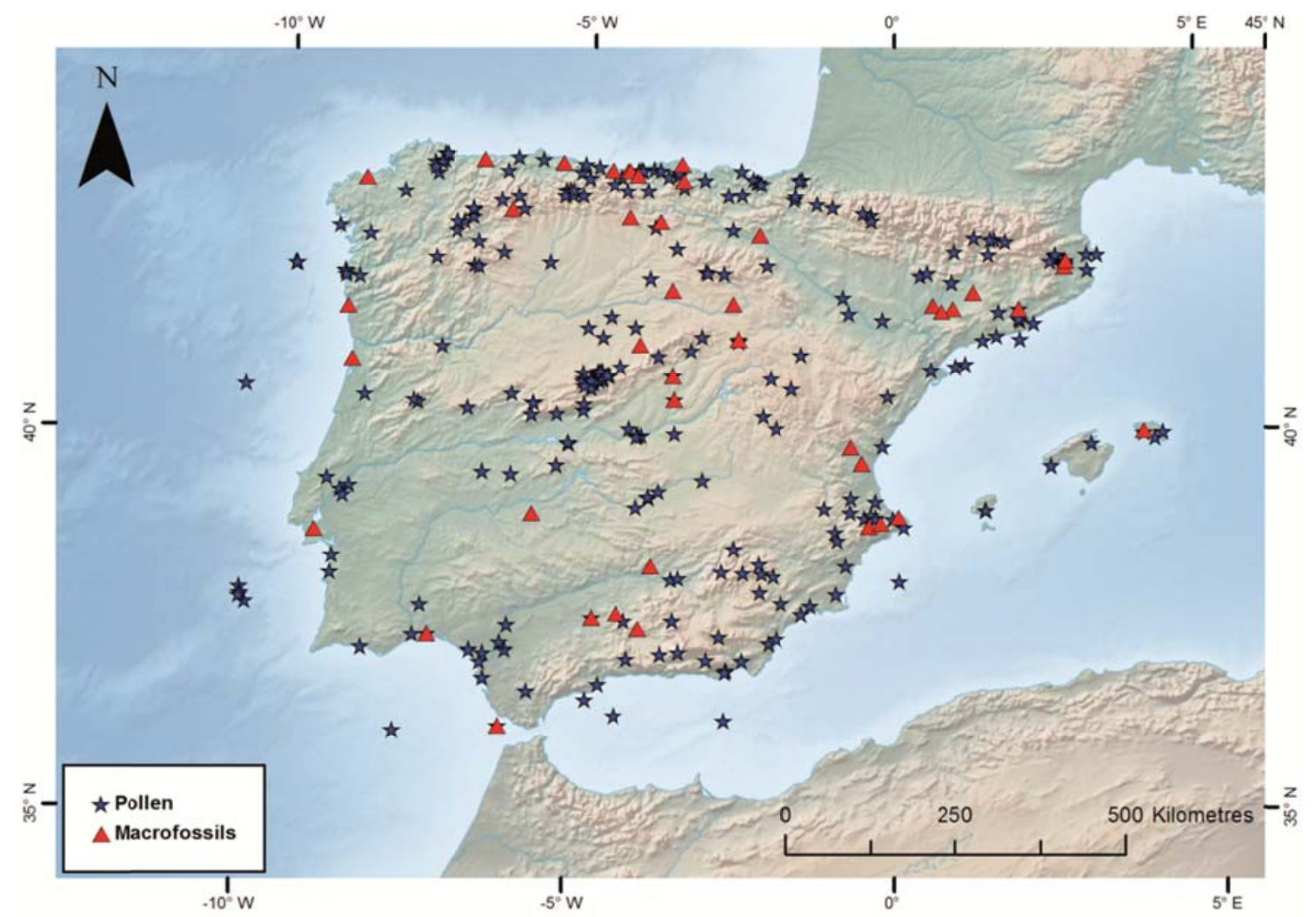

Fig. 2.4. Spatial distribution of palaeobotanical information on the Iberian Peninsula published in Paleodiversitas (Carrión et al., 2013). Aitoff's equal-area map projection used.

\subsection{USE OF QUATERNARY PALAEOBOTANICAL DATA IN SPECIES DISTRIBUTION MODEL STUDIES}

Species palaeodistributions are estimated by projecting current species distribution models onto past climatic conditions or by generating models that include past species data and palaeoclimatic simulations. Thus far, palaeobotanical data in SDM studies have been used in four different ways: 1) calibrate models under past climate conditions (e.g. Martínez-Meyer and Peterson, 2006), 2) quantitatively validate projected models calibrated on present-day species distributions (hindcasting) (e.g. Record et al., 2013), 3) visually assess (qualitative validation) the correspondence between the past projection of the species and the species fossil presence using overlapping maps without incorporating fossil data into the models either in the calibration or the validation processes (e.g. Carnaval and Moritz, 2008), and 4) evaluate the consistency in the hindcasted palaeodistributions of the species and fossil data from references (Eeley et al., 1999). 
The majority of the reviewed papers (see Table 2.1) used fossil data to quantitatively validate past models calibrated with current species distributions (e.g. De Lima et al., 2014), whereas fewer studies fitted models in the past with fossil occurrences (e.g. Williams et al., 2013a). Most articles used pollen data because of its higher direct availability for the time periods commonly modelled in global past climate simulations (6 and $21 \mathrm{ka} \mathrm{BP}$; Table 2.1). Macrofossil data are less frequent and therefore less common than pollen in SDM studies (see Alsos et al., 2009). To date, only a small portion of the studies reviewed included macrofossils in the analysis, and the macrofossils were always combined with pollen.

Palaeo-SDMs are generally used for specific late Quaternary periods, such as the midHolocene and Last Glacial Maximum, or for 1 kyr time steps from 24 ka cal BP to the present (Espíndola et al., 2012). Although rare, older periods can be modelled, such as in RodríguezSánchez and Arroyo (2008), who projected the distribution of Laurus L. to the mid-Pliocene (3 Ma; see Table 2.1).

Macrofossils are considered indicators of the local presence of a species (e.g. Salix herbacea L. in Alsos et al., 2009), although for fossil pollen assemblages (Table 2.1), local presence/absence of a species is defined using a species-specific threshold value in the pollen percentage (Alba-Sánchez et al., 2010). The same pollen threshold can be used for all the species in the study (Maiorano et al., 2013), or more than one threshold per species can be used to assess the sensitivity of the analysis to the threshold (Record et al., 2013). In certain SDM studies, the threshold is not specified by the authors (Roberts and Hamann, 2012b). In most of the studies, the thresholds are specified and referenced, although they may be different for the same species (e.g. $0.01 \%$ and $0.02 \%$ for Abies alba and Picea abies in Pearman et al. (2008); 1\% for Abies in Alba-Sánchez et al. (2010); 1\% for Abies alba, Picea abies and Fagus sylvatica in Maiorano et al. (2013); 0.5\% and 1\% for Fagus in Record et al. (2013)). Certain SDM studies have attempted to reduce the uncertainty of the threshold selection by using abundance pollen data (e.g. Moreno-Amat et al., 2015) or weighting percentages over the total tree pollen (Macias-Fauria and Willis, 2013).

In addition to using data obtained from authors or literature reviews (e.g. Benito-Garzón et al., 2007 and 2008), the most common sources of palaeobotanical data in SDM studies are databases that cover broad areas, such as the European and the North American Pollen Databases and Neotoma (e.g. Martínez-Meyer and Peterson, 2006, see Table 2.1). 
Table 2.1. Reviewed papers combining SDMs and palaeobotanical data.

\begin{tabular}{|c|c|c|c|c|c|c|}
\hline Reference & $\begin{array}{c}\text { Way of using } \\
\text { paleobotanical data }\end{array}$ & Time periods & $\begin{array}{l}\text { Type of fossil } \\
\text { data }\end{array}$ & $\begin{array}{l}\text { Source of fossil } \\
\text { data }\end{array}$ & Species & $\begin{array}{l}\text { Thresholds for past } \\
\text { presence/absence }\end{array}$ \\
\hline $\begin{array}{l}\text { Alba-Sánchez et al. } \\
\qquad(2010)\end{array}$ & 3- qualitative validation & $0,6,21 \mathrm{ka} \mathrm{BP}$ & Pollen & $\begin{array}{l}\text { European Pollen } \\
\text { Database and } \\
\text { literature review }\end{array}$ & $\begin{array}{l}\text { Abies alba and Abies } \\
\text { pinsapo }\end{array}$ & $\begin{array}{c}\text { Abies pollen } \\
\text { percentage } \\
1 \% \text { refering to } \\
\text { Iglesias (1998) for } \\
\text { supplementary } \\
\text { information } \\
\end{array}$ \\
\hline Alsos et al. (2009) & 3- qualitative validation & $\begin{array}{c}0,21 \mathrm{ka} \mathrm{BP} \text { and } \\
\text { future (2080) }\end{array}$ & $\begin{array}{l}\text { Macrofossils } \\
\text { and pollen }\end{array}$ & Literature review & Salix herbacea & Not specified \\
\hline $\begin{array}{l}\text { Benito-Garzón et al. } \\
\text { (2008) }\end{array}$ & 4- discussion & $\begin{array}{c}0,6,21 \mathrm{ka} \mathrm{BP} \\
\text { and future }(2020, \\
2050,2080)\end{array}$ & Pollen & Literature review & Pinus sylvestris & Not specified \\
\hline $\begin{array}{l}\text { Benito-Garzón et al. } \\
\text { (2007) }\end{array}$ & 3- qualitative validation & $0,6,21 \mathrm{ka} \mathrm{BP}$ & Pollen & Literature review & $\begin{array}{c}\text { Quercus robur, } Q . \\
\text { petraea, Q. pubescens, } \\
\text { Q. pyrenaica, Q. faginea } \\
\text { subsp. faginea, Q. faginea } \\
\text { subsp. broteroi, Q. suber, } \\
\text { Q. ilex subsp. ilex, Q. ilex } \\
\text { subsp. ballota, Castanea } \\
\text { sativa, Fagus sylvatica, } \\
\text { Pinus sylvestris, } P . \\
\text { uncinata, } P \text {. nigra nigra } \\
\text { subsp. salzmanii, } P . \\
\text { pinea, } P \text {. pinaster, } P . \\
\text { halepensis, Abies alba } \\
\text { and Juniperus thurifera } \\
\end{array}$ & Not specified \\
\hline $\begin{array}{l}\text { Carnaval and Moritz } \\
\text { (2008) }\end{array}$ & 3- qualitative validation & $0,6,21 \mathrm{ka} \mathrm{BP}$ & Pollen & Literature review & $\begin{array}{c}\text { Vegetation types } \\
\text { (Brazilian Atlantic forest) }\end{array}$ & Not specified \\
\hline Eeley et al. (1999) & 4- discussion & $\begin{array}{c}\text { Last Glacial } \\
\text { Maximum } \\
(\mathrm{LGM})(\approx 18,000 \\
\text { BP) } \\
\text { and the Holocene } \\
\text { altithermal }(\approx \\
7000 \mathrm{BP}), \\
\text { present and } \\
\text { future }(\mathrm{CO} 2 \\
\text { doubling } \\
\text { scenario) } \\
\end{array}$ & $\begin{array}{c}\text { Pollen, } \\
\text { palynological } \\
\text { and } \\
\text { palaeobiological } \\
\text { evidence }\end{array}$ & Literature review & $\begin{array}{l}\text { Eight different forest } \\
\text { subtypes }\end{array}$ & Not specified \\
\hline $\begin{array}{l}\text { Espíndola et al. } \\
\qquad(2012)\end{array}$ & 3- qualitative validation & $\begin{array}{l}\text { From } 24 \mathrm{kaBP} \text { to } \\
\text { present, } 1 \mathrm{kyr} \\
\text { time step }\end{array}$ & Pollen & $\begin{array}{c}\text { European Pollen } \\
\text { Database }\end{array}$ & Trollius europaeus & Not specified \\
\hline $\begin{array}{l}\text { Giesecke et al. } \\
\text { (2007) }\end{array}$ & 3- qualitative validation & 0 and $6 \mathrm{ka} \mathrm{BP}$ & Pollen & $\begin{array}{c}\text { Based in maps } \\
\text { made by } \\
\text { Gliemeroth (1995) } \\
\text { and selected pollen } \\
\text { diagrams across } \\
\text { Europe }\end{array}$ & Fagus sylvatica & $\begin{array}{l}1 \% \text { terrestrial pollen } \\
\text { for the maps } \\
\text { (Gliemeroth (1995) } \\
\text { and } 0.5 \% \text { for selected } \\
\text { pollen diagrams } \\
\text { across Europe (after } \\
\text { Brewer, 2002). }\end{array}$ \\
\hline Lima et al. (2014) & 2- quantitative validation & $6 \mathrm{ka} \mathrm{BP}$ & Pollen & Literature review & Mauritia flexuosa & Not specified \\
\hline $\begin{array}{l}\text { Macias-Fauria and } \\
\text { Willis (2013) }\end{array}$ & 2- quantitative validation & $\begin{array}{l}\text { Medieval Warm } \\
\text { Period (AD } \\
900-1300) \text {, the } \\
\text { Little Ice Age } \\
\text { (AD 1600-1850) } \\
\text { and present (AD } \\
1900-2000)\end{array}$ & Pollen & $\begin{array}{l}\text { European Pollen } \\
\text { Database }\end{array}$ & $\begin{array}{c}\text { Abies alba, Castanea } \\
\text { sativa, Fagus sylvatica, } \\
\text { Olea europaea, Picea } \\
\text { abies, Quercus ilex and } \\
\text { Vitis vinifera }\end{array}$ & $\begin{array}{l}\text { No threshold per } \\
\text { species used. } \\
\text { Presence/absence } \\
\text { matrix weighted by } \\
\text { each taxon's pollen } \\
\text { percentage over total } \\
\text { tree pollen }\end{array}$ \\
\hline $\begin{array}{l}\text { Maiorano et al. } \\
\text { (2013) }\end{array}$ & 1- calibration & $\begin{array}{l}\text { From } 13 \text { to } 1 \\
\text { kaBP, } 1 \text { kyr time } \\
\text { step }\end{array}$ & $\begin{array}{l}\text { Pollen and } \\
\text { macrofossils }\end{array}$ & $\begin{array}{l}\text { European Pollen } \\
\text { Database and } \\
\text { literature review }\end{array}$ & $\begin{array}{l}\text { Picea abies, Abies alba } \\
\text { and Fagus sylvatica }\end{array}$ & $\begin{array}{l}\text { Threshold value } 1 \% \\
\text { (Van der Knaap, } \\
\text { 2005) in current and } \\
\text { past pollen data }\end{array}$ \\
\hline $\begin{array}{l}\text { Martínez-Meyer and } \\
\text { Peterson (2006) }\end{array}$ & $\begin{array}{l}\text { 1- calibration and 2- } \\
\text { quantitative validation }\end{array}$ & 0 and $21 \mathrm{ka} \mathrm{BP}$ & Pollen & $\begin{array}{l}\text { Global Pollen } \\
\text { Database }\end{array}$ & $\begin{array}{c}\text { Acer rubrum, } A . \\
\text { saccharum type, Alnus } \\
\text { incana, A. viridis, } \\
\text { Brasenia schreberi, } \\
\text { Fraxinus nigra type, } \\
\text { Juglans cinerea and } \\
\text { Sarcobatus vermiculatus }\end{array}$ & Not specified \\
\hline $\begin{array}{l}\text { Moreno-Amat et al. } \\
\text { (2015) }\end{array}$ & 2- quantitative validation & $6 \mathrm{ka} \mathrm{BP}$ & Pollen & $\begin{array}{l}\text { Data from authors, } \\
\text { European Pollen } \\
\text { Database, } \\
\text { Paleodiversitas and } \\
\text { literature review }\end{array}$ & $\begin{array}{l}\text { Alnus glutinosa and } \\
\text { Corylus avellana }\end{array}$ & $\begin{array}{c}\text { Thresholds }(0.5 \% \text { for } \\
\text { Alnus glutinosa and } \\
1 \% \text { for Corylus } \\
\text { avellana) and species } \\
\text { abundance }\end{array}$ \\
\hline
\end{tabular}




\begin{tabular}{|c|c|c|c|c|c|c|}
\hline $\begin{array}{l}\text { Pearman et al. } \\
\text { (2008) }\end{array}$ & $\begin{array}{l}\text { 1- calibration and } 2- \\
\text { quantitative validation }\end{array}$ & 0 and $6 \mathrm{ka} \mathrm{BP}$ & Pollen & $\begin{array}{l}\text { European Pollen } \\
\text { Database and } \\
\text { Alpine } \\
\text { Palynological } \\
\text { Database }\end{array}$ & $\begin{array}{c}\text { Abies alba, Fagus } \\
\text { sylvestris, Larix decidua, } \\
\text { Picea abies, Carpinus } \\
\text { betulus, Corylus } \\
\text { avellana and Juniperus } \\
\text { communis } \\
\end{array}$ & $\begin{array}{l}2 \text { thresholds } \\
\text { (high/low) for each } \\
\text { species based in } \\
\text { expert knowledge } \\
\text { (references not } \\
\text { especified) }\end{array}$ \\
\hline $\begin{array}{c}\text { Poelchau and } \\
\text { Hamrick (2013) }\end{array}$ & $\begin{array}{l}\text { 3- qualitative validation } \\
\text { and 4- discussion }\end{array}$ & 0 and $21 \mathrm{ka} \mathrm{BP}$ & $\begin{array}{l}\text { Pollen and } \\
\text { reconstructed } \\
\text { Pleistocene } \\
\text { refugia maps }\end{array}$ & $\begin{array}{l}\text { Literature review } \\
\text { and reconstructed } \\
\text { Pleistocene refugia } \\
\text { from Brown (1987) }\end{array}$ & $\begin{array}{c}\text { Bursera simaruba, } \\
\text { Brosimum alicastrum, } \\
\text { Ficus insipida, Ficus } \\
\text { insipida, Apeiba } \\
\text { mebranacea, Asterogyne } \\
\text { martiana, Miconia affinis, } \\
\text { Poulsenia armata, } \\
\text { Symphonia globulifera, } \\
\text { Terminalia amazonia, } \\
\text { Acacia collinsii, Bauhinia } \\
\text { ungulata, Calycophyllum } \\
\text { candidissimum, Ficus } \\
\text { ovalis, Plumeria rubra } \\
\text { and Trichilia hirta } \\
\end{array}$ & Not specified \\
\hline Record et al. (2013) & 2- quantitative validation & $\begin{array}{l}\text { From } 8 \mathrm{ka} \mathrm{BP} \text { to } \\
\text { present, } 1 \mathrm{kyr} \\
\text { time step }\end{array}$ & Pollen & $\begin{array}{c}\text { Neotoma } \\
\text { Paleoecology } \\
\text { Database }\end{array}$ & Fagus, Tsuga & $\begin{array}{c}\text { Fagus: from } 0.5 \text { and } \\
1 \% \text {. Tsuga: from } 1 \\
\text { and } 2 \%\end{array}$ \\
\hline $\begin{array}{l}\text { Roberts and Hamann } \\
\qquad(2012 a)\end{array}$ & 2- quantitative validation & $\begin{array}{c}0,6,9,11,14,16 \\
\text { and } 21 \mathrm{ka} \mathrm{BP}\end{array}$ & $\begin{array}{l}\text { Pollen and } \\
\text { macrofossils }\end{array}$ & $\begin{array}{l}\text { Data complied by } \\
\text { Thompson and } \\
\text { Anderson }(2000) \\
\text { and Dyke (2005). }\end{array}$ & Biome classifications & Not specified \\
\hline $\begin{array}{l}\text { Roberts and Hamann } \\
\qquad(2012 \mathrm{~b})\end{array}$ & 2- quantitative validation & $\begin{array}{c}0,6,11,14,16 \\
\text { and } 21 \mathrm{ka} \mathrm{BP}\end{array}$ & $\begin{array}{l}\text { Pollen and } \\
\text { macrofossils }\end{array}$ & $\begin{array}{l}\text { North American } \\
\text { Pollen Database, } \\
\text { Anderson et al. } \\
\text { (1988), Thompson } \\
\text { and Anderson } \\
\text { (2000) and Dyke } \\
\text { (2005). }\end{array}$ & $\begin{array}{c}\text { Abies amabilis, Abies } \\
\text { lasiocarpa, Abies } \\
\text { procera, Acer } \\
\text { macrophyllum, Alnus } \\
\text { rubra, Betula papyrifera, } \\
\text { Calocedrus decurrens, } \\
\text { Chamaecyparis } \\
\text { nootkatensis, Larix } \\
\text { occidentalis, Picea } \\
\text { engelmannii, Picea } \\
\text { glauca, Picea mariana, } \\
\text { Picea sitchensis, Pinus } \\
\text { albicaulis, Pinus } \\
\text { contorta, Pinus edulis, } \\
\text { Pinus monticola, Pinus } \\
\text { ponderosa, Populus } \\
\text { tremuloides, Pseudotsuga } \\
\text { menziesii, Sequoia } \\
\text { sempervirens, Thuja } \\
\text { plicata, Tsuga } \\
\text { heterophylla and Tsuga } \\
\text { mertensiana } \\
\end{array}$ & Not especified \\
\hline $\begin{array}{l}\text { Rodríguez-Sánchez } \\
\text { and Arroyo (2008) }\end{array}$ & $\begin{array}{l}\text { 1- calibration and } 2- \\
\text { quantitative validation }\end{array}$ & $\begin{array}{c}3 \mathrm{Ma} \mathrm{BP}, 0 \text { and } \\
21 \mathrm{ka} \mathrm{BP} \text { and } \\
\text { future }(\mathrm{CO} 2 \\
\text { doubling } \\
\text { scenario) } \\
\end{array}$ & Not specified & Literature review & Laurus & Not specified \\
\hline Vesella et al. (2015) & 3- qualitative validation & $\begin{array}{c}0,6,21 \text { and } 130 \\
\text { ka BP }\end{array}$ & $\begin{array}{c}\text { Pollen and } \\
\text { charcoal }\end{array}$ & Literature review & Quercus suber & Not specified \\
\hline Werneck et al. 2012 & 3- qualitative validation & $\begin{array}{l}0,6,21 \text { and } 120 \\
\text { ka BP }\end{array}$ & Pollen & Literature review & $\begin{array}{l}\text { Vegetation types } \\
\text { (Brazilian Cerrado) }\end{array}$ & Not specified \\
\hline $\begin{array}{l}\text { Williams et al. } \\
\text { (2013b) }\end{array}$ & 1- calibration & $\begin{array}{l}\text { From } 22 \mathrm{ka} \mathrm{BP} \\
\text { to present, } 1 \mathrm{kyr} \\
\text { time step }\end{array}$ & Pollen & $\begin{array}{l}\text { Williams et al. } \\
\text { (2004) and North } \\
\text { American Pollen } \\
\text { Database }\end{array}$ & $\begin{array}{c}\text { Abies, Acer, Alnus, } \\
\text { Ambrosia, Artemisia, } \\
\text { Asteraceae, Betula, } \\
\text { Carya, } \\
\text { Cupressaceae/Taxaceae, } \\
\text { Cyperaceae, Fagus, } \\
\text { Fraxinus, } \\
\text { Ostrya/Carpinus, Picea, } \\
\text { Pinus strobus, Pinus } \\
\text { subg. Pinus (north-eastern } \\
\text { US species), Pinus subg. } \\
\text { Pinus (south-eastern US } \\
\text { species), Populus, } \\
\text { Quercus, Ranunculaceae, } \\
\text { Salix, Tsuga, and Ulmus } \\
\end{array}$ & Species abundance \\
\hline
\end{tabular}

\subsection{CONCLUSIONS}

Palaeobotanical data provide valuable and objective information on the past occurrence of species and are therefore needed to evaluate palaeo-SDM estimations. Accordingly, in the last decade, the combination of SDMs with palaeobotanical data has been increasingly used to test 
a large range of hypotheses in the fields of biogeography, palaeobiology and palaeoecology. However, there are various particular aspects of palaeobotanical data that might compromise the conclusions of SDM studies, such as species representativity, taxonomy and chronological control of the data.

All of the limitations in the palaeodata can be controlled when studying a few fossil records at a local scale. However, at global spatial scales, it becomes increasingly difficult to control the inherent assumptions and uncertainties. When the fossil data are obtained from several sources or global palaeoecological databases, important information regarding the chronological control, taphonomic processes and/or taxonomic resolution are not always easy to obtain. Consequently, SDM users should seek a balance between data quality and data quantity by carefully verifying the datasets (Brewer et al., 2012).

As a general recommendation, we suggest that the procedures used in each of the stages mentioned (species representativity, taxonomy, chronology control and data characteristics) should be detailed in the corresponding material and methods section. The number of past occurrences per time interval used in the SDM (e.g. Maiorano et al., 2013) should also be included. These suggestions are provided to call attention to the size and quality of the data, quantify the robustness of the results and improve the repeatability of the analyses. Overall, the uncertainties in palaeobotanical data can be managed when studying a few fossil records at a local scale. Nonetheless, controlling the assumptions and uncertainties produced in the modelling process at the global scale is difficult, especially if the data are obtained from global palaeoecological databases.

The inclusion of macrofossils data definitely improves the taxonomic and chronological resolution of palaeoecological analyses. If macrofossils are not available, besides collecting more data, we suggest that SDM users should pay attention to the pollen chronology and review the taxonomical implications that might arise from the taxa selected for the study area. Important attention must be paid when using the calibration and depth-age chronological methods to generate SDMs to avoid mistakes, which can be accomplished by filtering the data by a number of reliable dates or by using benchmarking sequences (Blois et al., 2011).

Fortunately, the growing availability of palaeoecological data has increased the prospects of SDMs. Improvements to methodological approach will require a balance between the amount and the quality of the data, although the most important improvement is related to nourishing the palaeoecological community. Therefore, datasets should be completed with 
data obtained from local databases and valuable published literature from non-contemporary sources. 


\section{INFLUENCIA DE LA COMPLEJIDAD DE LOS MODELOS Y DEL TIPO DE VALIDACIÓN CON DATOS PALEOBOTÁNICOS EN EL PROCESO DE MODELIZACIÓN Y EN LA TRANSFERIBILIDAD TEMPORAL DE LOS MODELOS.}

Este capítulo reproduce integramente el texto publicado en:

Moreno-Amat, E., Mateo, R.G., Nieto-Lugilde, D., Morueta-Holme, N., Svenning, J.C., García-Amorena, I., 2015. Impact of model complexity on cross-temporal transferability in Maxent species distribution models: An assessment using paleobotanical data. Ecological Modelling, 312, 308-317. (Anexo 1)

\subsection{RESUMEN}

Maxent es un algoritmo de modelización ampliamente utilizado para predecir la distribución de las especies en el espacio y el tiempo. La evaluación adecuada de la incertidumbre de estas predicciones es fundamental y requiere la validación con datos independientes. En concreto, la complejidad de los modelos (número de parámetros del modelo) es una preocupación importante en relación con el sobreajuste del modelo a los datos (overfitting) y, por tanto, de la transferibilidad de los modelos de Maxent. Una estrategia reciente es la validación de la transferibilidad de los modelos entre periodos temporales con datos paleobotánicos. En este capítulo se estudia el efecto de la complejidad de los modelos en su capacidad predictiva en el tiempo usando dos especies vegetales europeas (Alnus glutinosa (L.) Gaertn. y Corylus avellana L.) las cuales cuentan con un extenso registro fósil en España para el final del Cuaternario. Para ello se ajustaron 110 modelos con diferentes niveles de complejidad en el presente y se evaluó su capacidad predictiva por medio de los estadísticos AUC (área bajo la curva ROC) y AICc (criterio de información de Akaike corregido) mediante el procedimiento estándar de división aleatoria de los datos de presencias. Por último, estos resultados se compararon con una validación independiente mediante la proyección de los modelos bajo las condiciones climáticas del Holoceno medio (6.000 años cal BP) para evaluar su habilidad para predecir las presencias o ausencias del polen fósil y su abundancia. La calibración de los modelos de Maxent con la configuración predeterminada por defecto resultan en modelos excesivamente complejos. Mientras que la capacidad predictiva del modelo aumenta con la complejidad en los modelos actuales, es mayor en modelos de complejidad intermedia al predecir las distribuciones en el Holoceno medio. Los valores óptimos para predecir la distribución actual y pasada se encuentran en modelos con una complejidad intermedia. La obtención de modelos con predicciones fiables 
en el tiempo es especialmente importante para predecir las distribuciones futuras bajo escenarios de cambio climático. Por ello, se recomienda seleccionar los parámetros de complejidad de los modelos que mejor funcionan para cada estudio y especie y validar los resultados de los modelos con datos paleobotánicos cuando estos estén disponibles. Como los datos paleobotánicos son escasos, se recomienda el uso de modelos más simples, con una complejidad intermedia, cuando el objetivo del estudio es la predicción de la distribución actual y pasada de una especie.

Palabras clave: Polen fósil, Corylus avellana, Alnus glutinosa, validación, modelos de distribución de especies, $\beta$-multiplier.

\subsection{ABSTRACT}

Maximum entropy modeling (Maxent) is a widely used algorithm for predicting species distributions across space and time. Properly assessing the uncertainty in such predictions is non-trivial and requires validation with independent datasets. Notably, model complexity (number of model parameters) remains a major concern in relation to overfitting and, hence, transferability of Maxent models. An emerging approach is to validate the cross-temporal transferability of model predictions using paleoecological data. In this study, we assess the effect of model complexity on the performance of Maxent projections across time using two European plant species (Alnus glutinosa (L.) Gaertn. and Corylus avellana L.) with an extensive late Quaternary fossil record in Spain as a study case. We fit 110 models with different levels of complexity under present time and tested model performance using AUC (area under the receiver operating characteristic curve) and AICc (corrected Akaike Information Criterion) through the standard procedure of randomly partitioning current occurrence data. We then compared these results to an independent validation by projecting the models to mid-Holocene (6000 years before present) climatic conditions in Spain to assess their ability to predict fossil pollen presence-absence and abundance. We find that calibrating Maxent models with default settings result in the generation of overly complex models. While model performance increased with model complexity when predicting current distributions, it was higher with intermediate complexity when predicting mid-Holocene distributions. Hence, models of intermediate complexity resulted in the best trade-off to predict species distributions across time. Reliable temporal model transferability is especially relevant for forecasting species distributions under future climate change. Consequently, species-specific model tuning should be used to find the best modeling settings to control for complexity, 
notably with paleoecological data to independently validate model projections. For crosstemporal projections of species distributions for which paleoecological data is not available, models of intermediate complexity should be selected.

Keywords: Pollen fossil, Corylus avellana, Alnus glutinosa, model validation, species distribution model, $\beta$-multiplier.

\subsection{INTRODUCTION}

Species distribution models (SDMs) are widely used algorithms for describing ecological patterns and estimating the ecological niche or the potential distribution of species across space and time (Elith and Leathwick, 2009). Mechanistic SDMs use functional traits and physiological constraints to predict the response of an individual (or a population) to environmental conditions (Kearney et al., 2010 and Morin and Thuiller, 2009), whilst correlative SDMs relate species known occurrences and environmental variables (Guisan and Zimmermann, 2000). While mechanistic models may provide a more reliable and realistic picture because they can include processes that limit species distribution (Kearney et al., 2010), correlative models are the most frequently used in climate change studies (Araújo and Peterson, 2012) and to inform decision-making in conservation (Araújo et al., 2011). For that reason, evaluating the uncertainty and predictive ability of correlative SDMs is crucial.

Model complexity is well known to affect uncertainty of models and their transferability across space and time (Warren et al., 2014). However, the complexity of models is usually disregarded, especially when projecting SDMs across time. In addition, evaluating models requires occurrences independent from the calibration datasets, particularly when projecting models into the future, where such data are lacking (Araújo et al., 2005). One approach is to project models back in time and validate them with paleoecological data (Svenning et al., 2011). For example, paleobotanical records, which provide information on vegetation composition of the past, can be used as independent datasets to validate the past predictions of SDMs calibrated on present-day plant distributions (e.g. Pearman et al., 2008 and Record et al., 2013, among others). Model complexity, defined as the number of parameters included in a model, is crucial for inferring habitat quality and estimating the breadth of species' niches (Warren and Seifert, 2011). Besides, complexity can also negatively affect the predictive performance of a model as a result of overfitting (Warren and Seifert, 2011). Although recent studies have assessed different aspects of complexity on SDM performance (e.g. Merow et al., 2014, Muscarella et al., 2014, Syfert et al., 2013 and Warren and Seifert, 2011, among 
others), only one study has explored the uncertainty associated with model complexity on SDM projections for future climate scenarios (Warren et al., 2014). However, the effects of complexity on the predictive ability of SDMs across time remain poorly known.

Among the different SDM algorithms, maximum entropy (Maxent; Phillips et al., 2006) is extensively used for projecting current species distributions to different time periods (Elith and Leathwick, 2009). Maxent is a very flexible modeling algorithm widely used because of its better predictive performance relative to other modeling algorithms (Elith et al., 2006) even with low sample sizes (Pearson et al., 2007), its applicability to presence-only data (Phillips et al., 2006), and its user-friendly interface as well as availability through the dismo package (Hijmans and Elith, 2013). Maxent has been described as a modeling method able to fit overly complex response curves (Elith and Leathwick, 2009), particularly when using default parameters (Merow et al., 2013). Recently Maxent has been proved to be mathematically equivalent to a Poisson regression, a particular type of generalized linear models (GLM; Renner and Warton, 2013). The default settings of Maxent have been tested over a wide range of species and environmental conditions (Phillips and Dudík, 2008), but not in relation to cross-temporal transferability.

The complexity of Maxent models can be adjusted mainly through the choice of (1) the number of environmental predictors, (2) the feature classes allowed, and (3) the regularization ( $\beta$-multiplier) selected in the model. The initial selection of the number of environmental predictors that best describe the species' ecological niche has a great influence on model performance (Harris et al., 2013 and Synes and Osborne, 2011). Generally, this selection is based on previous knowledge of the ecology of the species and/or statistical assessments (Morueta-Holme et al., 2010). The Maxent algorithm consists of an iterative process that automatically selects the features that best explain the species' distribution (Merow et al., 2013). Features are basis functions and other transformations of the environmental predictors (i.e. linear, quadratic, product - i.e. interaction between variables - threshold and/or hinge; Phillips and Dudík, 2008). The features considered can be manually set by the user (Phillips and Dudík, 2008), or automatically by the algorithm when using the "autofeatures" option. Finally, given a fixed number of predictors and features allowed in the model, Maxent controls for model complexity through the regularization parameter (a set of parameters called beta-multipliers). Maxent forces the predicted values of the variables such as mean and variance to match the values of the presence locations. Thus, the regularization parameter prevents Maxent from over-fitting assuring that the predicted values do not fit too exactly the 
empirical constraints of the predictor (Merow et al., 2013). Higher values of regularization parameter penalize the inclusion of parameters, thus creating less complex models than the default (regularization parameter $=1$ ). Also the $\beta$-multiplier limits the number of features included in the model based on the number of presences (with more data allowing for an increasing number of features; Merow et al., 2013). Even though Maxent-users can control model complexity by modifying default setting options (i.e. model specifications; Phillips et al., 2006), in most studies using Maxent, model complexity is completely ignored (Muscarella et al., 2014, Warren et al., 2014 and Yackulic et al., 2013).

Here, we study the effect of model complexity on the ability of Maxent models to predict species distributions across time. Specifically, we fit models with current presence data for Alnus glutinosa (L.) Gaertn. and Corylus avellana L. and different levels of complexity, and compare their performance when predicting both present and mid-Holocene distributions. Furthermore, we analyze whether the Maxent default settings are optimal to project these species under both current and past climate conditions. These two European species are ideal for evaluating model projections across time due to their wide current distribution across Europe and their strong representation in the fossil record.

\subsection{MATERIALS AND METHODS}

\subsubsection{Study area}

Correlative SDMs assume the equilibrium of species with climate and that the training data are illustrative of environment to which the models are predicted (Elith et al., 2010). In order to account for the full ecological range of the species (Hijmans and Elith, 2013), we fit models using available current occurrences from Europe. We used the paleorecord from continental Spain to validate the model projections to past climatic conditions. Consequently, we avoided truncating the niche estimation and reduced the likelihood of extrapolating, i.e. projecting outside the climatic conditions present in the training data (Elith et al., 2010). Following Elith et al. (2010) we checked for extrapolation, with a multivariate environmental similarity surface analysis (MESS), by comparing the current climatic conditions contained in the calibration dataset and mid-Holocene climatic conditions (Fig. C1).

\subsubsection{Study species}

A. glutinosa (black alder) and C. avellana (hazel) are widely distributed in the Atlantic and Centro-European Region, and have their southern geographical limits in the Mediterranean 
Region (Fig. 3.1). The distribution of A. glutinosa ranges from Ireland to western Siberia and from mid-Scandinavia to Northern Africa (Morocco and Algeria; Kajba and Gračan, 2003). Meanwhile, C. avellana populations are distributed from Ireland to the Ural Mountains in Russia and from Scandinavia to southern Spain (Castroviejo et al., 1986-2016).
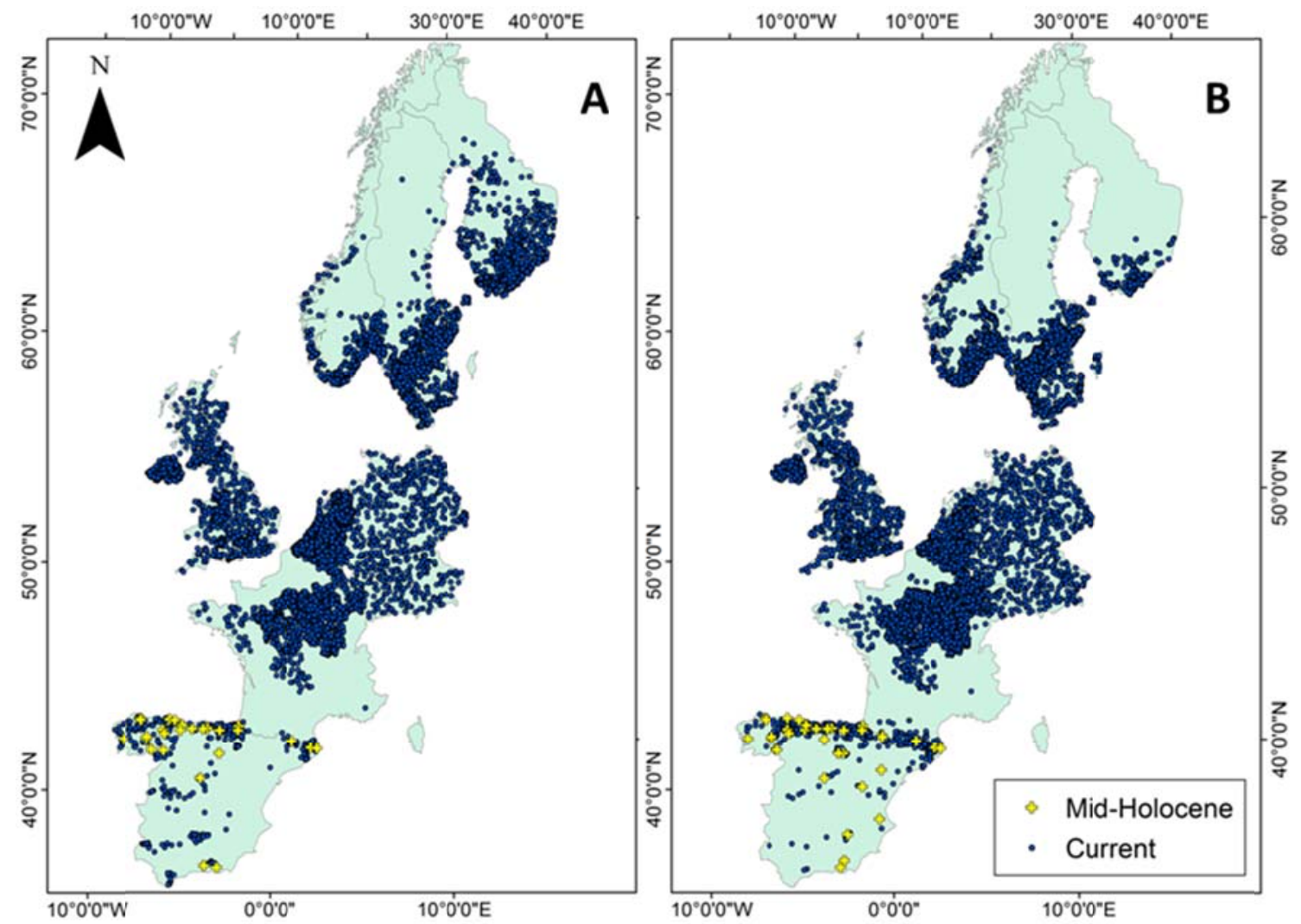

Fig. 3.1. Study region and distribution of study species. Blue dots: GBIF current species presences used in the analysis. Yellow crosses: mid-Holocene pollen presences in Spain for Alnus (A) and Corylus (B).

Within Spain, the two species are mainly found in the northern mountainous region with some scattered populations in the southwestern part of the country (Castroviejo et al., 19862016). According to the pollen record, and considering the lack of mid-Holocene pollen records in Western and Southwestern continental Spain, the current distribution of both species in Spain is similar to that of the mid-Holocene (Fig. 3.1). Additionally, identification of their pollen is very reliable, as they are the only species within their respective genera present during the Holocene in the Iberian Peninsula.

\subsubsection{Presence data}

Current occurrence data for the two species were obtained from the Global Biodiversity Information Facility database (GBIF; http:/www.gbif.org/ accessed January 2012). We excluded occurrences with a reported coordinate precision $\geq 10 \mathrm{~km}$ as well as countries not represented in GBIF or with uneven sampling effort (Mateo et al., 2013). Thus, we only 
included occurrences from Andorra, Belgium, Finland, France, Germany, Netherlands, Norway, Spain, Sweden and United Kingdom (Fig. 3.1). From the extracted $\sim 50,000$ presences per species, 10,000 records were randomly subsampled with $1 \mathrm{~km}$ minimum distance (Beck et al., 2014 and Mateo et al., 2013) to reduce computing time. Non-metric multidimensional scaling (NMDS) analyses were performed with the distributions obtained from GBIF and the whole European distributions as in Atlas Florae Europaeae (Jalas and Suominen, 1972-1994) at $50 \mathrm{~km}$ for both species (Fig. D1). We discard the possibility of geographical bias in the calibration dataset leading to an environmental bias because there is an overlap in the environmental space between the GBIF data and the AFE data for both species as observed in (Figs. D1-D2).

We obtained paleorecords for the mid-Holocene in Spain (Fig. 3.1) from the European Pollen Database (2007-2015) (EPD; http://www.europeanpollendatabase.net), the Spanish research project Paleodiversitas (Carrión et al., 2013 and Paleodiversitas, 2011, http://www.paleodiversitas.org/) and other references (Table A1 and references in Appendix A). The pollen percentages of each species were estimated relative to the total amount of terrestrial plant pollen grains (i.e. excluding wetland and aquatic species) for the $6 \pm 0.25 \mathrm{kyr}$ cal BP interval. Pollen data obtained from the EPD or directly provided by the authors were expressed as the average of pollen percentages. We estimated percentages for the remaining pollen records from pollen diagrams. To locate the studied time period when ages in the diagrams were not expressed as calendar years, we calibrated the radiocarbon dates using the program CALIB 6.0 (Stuiver et al., 2012) coupled with the INTCAL09 calibration curve (Reimer et al., 2009), and constructed an age-depth model using linear-interpolation between consecutive $14 \mathrm{C}$ datings. Only pollen records with chronologies built with two or more $14 \mathrm{C}$ datings were used.

We classified pollen percentages into presence/absence using a $0.5 \%$ and $1 \%$ threshold for Alnus and Corylus, respectively (Lisitsyna et al., 2011 and Szczepanek et al., 2004). For Alnus, the $0.5 \%$ threshold provides the highest agreement between pollen and vegetation data (Lisitsyna et al., 2011). For Corylus, a 1\% threshold was recommended by Lisitsyna et al. (2011).

A total of 55 pollen sites were studied (Table A1), with 27 presences and 28 absences for Alnus and 36 presences and 19 absences for Corylus in the Iberian Peninsula (Fig. 3.5). Since both Alnus and Corylus are wind pollinated taxa with high pollen production (Erdtman et al., 
1969), underrepresentation of species in the pollen core is rare. Hence, absences in pollen sites can be considered reliable.

\subsubsection{Climate data}

Current climate data for Europe were downloaded from the WORLDCLIM database (http://www.worldclim.org/; Hijmans et al., 2005) at 30 as $(\sim 1 \mathrm{~km} 2)$ resolution. This database provides 19 bioclimatic variables derived from monthly temperature and precipitation data for the 1950-2000 period. These variables represent annual trends, seasonality and extremes in climate that act as limiting environmental factors for many organisms (Hijmans et al., 2005 and Kumar and Stohlgren, 2009).

In order to reproduce mid-Holocene climatic conditions in the Iberian Peninsula and to determine the effect of the General Circulation Model, we used two Ocean Atmospheric General Circulation Models (OA-GCMs): the CCSM (http://www.ccsm.ucar.edu;Kiehl and Gent, 2004) and the MIROC3.2 (http://www.ccsr.u-tokyo.ac.jp/ehtml/etopindex.shtml). Monthly values of temperature and precipitation for the two OA-GCMs were compiled from the Paleoclimate Modeling Intercomparison Project Phase 2 (PMIP2) database. The variables were extracted at the original resolution $\left(2.5^{\circ}\right.$ cell sizes $)$ covering the entire Iberian Peninsula. Following the standard change-factor approach to downscale the data, we computed anomalies between mid-Holocene and current climatic conditions from the OA-GCMs output, and downscaled the anomalies to a spatial resolution of 30 as using regularized splines. To avoid potential estimations of negative values of precipitation, the anomalies for this variable were calculated as relative differences (Hijmans and Graham, 2006 and Lima-Ribeiro et al., 2013). Finally, mid-Holocene climates were calculated adding the interpolated differences to the current climate (i.e. pre-industrial values) from the WORLDCLIM database. This approach accounts for the effect of topography, ensuring consistency of the climatic patterns across time (Hijmans and Graham, 2006). Finally, the 19 bioclimatic variables were calculated from the downscaled data of past monthly temperatures and precipitations.

\subsubsection{Model calibration and tuning of complexity}

We ran the models with the Maxent modeling algorithm version 3.3.3k (Phillips et al., 2006). Present distribution models for both species were developed with the occurrence data and 10,000 random background points, representing the distribution of environmental conditions in the study region (Phillips and Dudík, 2008). To avoid a geographical bias in our 
models, we randomly chose the background points from the same European countries for which presences were used. Because we were interested in studying the variation in performance across models, we built all the models with the same occurrence and background data to avoid any potential source of variation due to differences in data input. We randomly selected $70 \%$ of the data (both presences and background) to fit the models and held the remaining 30\% for testing purposes running one replicate per model. To project the models under mid-Holocene conditions we used clamping, the default setting in Maxent in case of extrapolation, i.e. making the response constant outside of the range of the training data (Elith et al., 2010). Finally, we used the logistic output for the final geographical predictions (Phillips and Dudík, 2008).

We analyzed three potential sources of complexity: number of variables, number and type of features included in the model, and $\beta$-multipliers. To do so, we calibrated a total of 110 models for each species. First, we selected five subsets of nested predictor variables (with 4, 10, 13, 15 and 19; Table 3.1). The 4 variables set was based on ecological criteria (Pearman et al., 2008 and Prentice et al., 1992) and avoiding correlated variables (Pearson $r \geq 0.75$ ), with increasing correlation allowed in the subsequent set of variables. Second, we compared two different sets of feature classes: the default "autofeatures" option (which allows all possible features), and allowing only linear, quadratic, and product (LQP) features. We used LQP all together because species responses to ecological gradients are frequently nonlinear. Quadratic responses are suitable for unimodal curves, as expected for fundamental niches (Austin, 2007), and product, i.e. interaction between variables, is not rare. Autofeatures include for LQP plus threshold and hinge features, which are useful when there is a physiological tolerance limit (Merow et al., 2013). Finally, we tested 11 different $\beta$-multipliers (from 0 to 5 in steps of 0.5). The most complex model resulted from the combination of the highest number of variables (19 variables), the lowest $\beta$-multiplier $(\beta=0)$ and enabled autofeatures, whereas the simplest model arose from using the smallest number of variables (four variables), the highest $\beta$-multiplier $(\beta=5)$, and allowing only LQP features in the model. 
Table 3.1. Environmental variables (http://www.worldclim.org/; Hijmans et al., 2005) with indication of the sets of nested variables (4var, 10var, 13var, 15var and 19var) used to fit the models.

\begin{tabular}{|c|c|c|c|c|c|c|}
\hline & \multirow{2}{*}{ Description } & \multicolumn{5}{|c|}{ Variable set } \\
\hline & & 4var & 10var & 13 var & $15 \mathrm{var}$ & 19var \\
\hline $\mathrm{BIO} 01$ & Annual Mean Temperature & & & & $\mathrm{X}$ & $\mathrm{X}$ \\
\hline $\mathrm{BIO} 02$ & $\begin{array}{l}\text { Mean Diurnal Range (Mean of monthly (max } \\
\text { temp - min temp)) }\end{array}$ & & $\mathrm{X}$ & $\mathrm{X}$ & $\mathrm{X}$ & $\mathrm{X}$ \\
\hline $\mathrm{BIO} 03$ & Isothermality $(\mathrm{BIO} 2 / \mathrm{BIO} 7)(* 100)$ & & & $\mathrm{X}$ & $\mathrm{X}$ & $\mathrm{X}$ \\
\hline $\mathrm{BIO} 04$ & $\begin{array}{c}\text { Temperature Seasonality (standard deviation } \\
* 100 \text { ) }\end{array}$ & & & $\mathrm{X}$ & $\mathrm{X}$ & $\mathrm{X}$ \\
\hline BIO 05 & Max Temperature of Warmest Month & & $\mathrm{X}$ & $\mathrm{X}$ & $\mathrm{X}$ & $\mathrm{X}$ \\
\hline BIO 06 & Min $\mathrm{T}^{\mathrm{o}}$ Coldest Month & $\mathrm{X}$ & $\mathrm{X}$ & $\mathrm{X}$ & $\mathrm{X}$ & $\mathrm{X}$ \\
\hline $\mathrm{BIO} 07$ & Temperature Annual Range (BIO5-BIO6) & & $\mathrm{X}$ & $\mathrm{X}$ & $\mathrm{X}$ & $\mathrm{X}$ \\
\hline BIO 08 & Mean Temperature of Wettest Quarter & & & & & $\mathrm{X}$ \\
\hline $\mathrm{BIO} 09$ & Mean Temperature of Driest Quarter & & & & & $\mathrm{X}$ \\
\hline BIO 10 & Mean $\mathrm{T}^{\circ}$ Warmest Quarter & $\mathrm{X}$ & $\mathrm{X}$ & $\mathrm{X}$ & $\mathrm{X}$ & $\mathrm{X}$ \\
\hline BIO 11 & Mean Temperature of Coldest Quarter & & $\mathrm{X}$ & $\mathrm{X}$ & $\mathrm{X}$ & $\mathrm{X}$ \\
\hline $\mathrm{BIO} 12$ & Annual Precipitation & $\mathrm{X}$ & $\mathrm{X}$ & $\mathrm{X}$ & $\mathrm{X}$ & $\mathrm{X}$ \\
\hline BIO 13 & Precipitation of Wettest Month & & & & & $\mathrm{X}$ \\
\hline BIO 14 & Precipitation of Driest Month & & & $\mathrm{X}$ & $\mathrm{X}$ & $\mathrm{X}$ \\
\hline BIO 15 & $\begin{array}{l}\text { Precipitation Seasonality } \\
\text { Variation) }\end{array}$ & & $\mathrm{X}$ & $\mathrm{X}$ & $\mathrm{X}$ & $\mathrm{X}$ \\
\hline BIO 16 & Precipitation of Wettest Quarter & & & & $\mathrm{X}$ & $\mathrm{X}$ \\
\hline BIO 17 & Precipitation Driest Quarter & $\mathrm{X}$ & $\mathrm{X}$ & $\mathrm{X}$ & $\mathrm{X}$ & $\mathrm{X}$ \\
\hline BIO 18 & Precipitation of Warmest Quarter & & $\mathrm{X}$ & $\mathrm{X}$ & $\mathrm{X}$ & $\mathrm{X}$ \\
\hline BIO 19 & Precipitation of Coldest Quarter & & & & & $\mathrm{X}$ \\
\hline
\end{tabular}

\subsubsection{Model evaluation}

In order to evaluate the performance of models under current climate conditions, we used two methods. First, we calculated the AUC (Area Under the receiver operating characteristic Curve) using the testing dataset (30\% of the presences and background; Araújo et al., 2005). AUC is a threshold independent statistic that informs about the ability of a model to discriminate between presences and absences from the study area (Fielding and Bell, 1997 and Lobo et al., 2008). AUC has become the standard to assess the predictive accuracy of SDMs, allowing comparisons among different models for a single species and a single study region (Lobo et al., 2008). Second, we calculated the Akaike Information Criterion corrected for small sample sizes (AICc; Johnson and Omland, 2004) since AUC does not account for goodness-of-fit of the model, model complexity, or the increase of false absences due to the use of background data (Lobo et al., 2008 and Warren and Seifert, 2011). AICc is a balanced statistic between the goodness of fit and the number of parameters of the model (Johnson and Omland, 2004), which allows selecting models with optimal complexity (Warren and Seifert, 
2011). Additionally, we assessed the differences in suitability of the best current models selected according to AUC and AICc projected to geographical space.

To evaluate projections to mid-Holocene climate conditions in continental Spain, we used the fossil pollen data as independent datasets. Here, we calculated AUC, which tests the ability of the models' mid-Holocene projections to discriminate between real mid-Holocene presence and absence of the species derived from thresholded pollen data (e.g. Pearman et al., 2008). Because pollen from wind pollinated taxa can represent presences at coarser spatial scales than our analysis (Nieto-Lugilde et al., 2015), we also calculated the correlation (Spearman coefficient) between pollen percentages and the habitat suitability values predicted by the model. Pollen percentages should be less sensible to scale than presences/absences derived from pollen thresholds. This correlation also served as a sensitivity test to assess whether the percentage and threshold analyses lead to the same results, since most SDM studies using pollen data only use thresholded values (Pearman et al., 2008 and Record et al., 2013) and there is no consensus in the percentage that defines the presence for each species (Lisitsyna et al., 2011). AICc was not calculated in the past because it was obtained only for the calibrated models which were the current ones.

All the analysis were conducted with the R software (packages: vegan, dismo and raster; http://cran.r-project.org/) except for the AICc analysis, which was run with the software ENMtools (Warren et al., 2010). Past climate variables were transformed with GRASS GIS software (GRASS Development Team, 2012).

\subsection{RESULTS}

\subsubsection{Evaluation of current species distributions}

The AUC on the test dataset varied from 0.765 to 0.889 (mean \pm s.d. $=0.844 \pm 0.032$ ) for Alnus (Fig. 3.2A-C) and from 0.748 to $0.879(0.823 \pm 0.034)$ for Corylus (Fig. 3.2D-F). For both species, AUC increased with model complexity. The highest values were thus observed in the most complex models-i.e. models resulting from combining 19 variables, $\beta=0$ and autofeatures. Conversely, the lowest AUC values were obtained with the simplest model-i.e. when combining four variables, $\beta=5$, and allowing only LQP features (Fig. 3.2C and F). When the number of parameters exceeded 100-125 the AUC values reached a plateau. Differences in AUC between the five variable sets were small, except for the models run with 4 variables. 

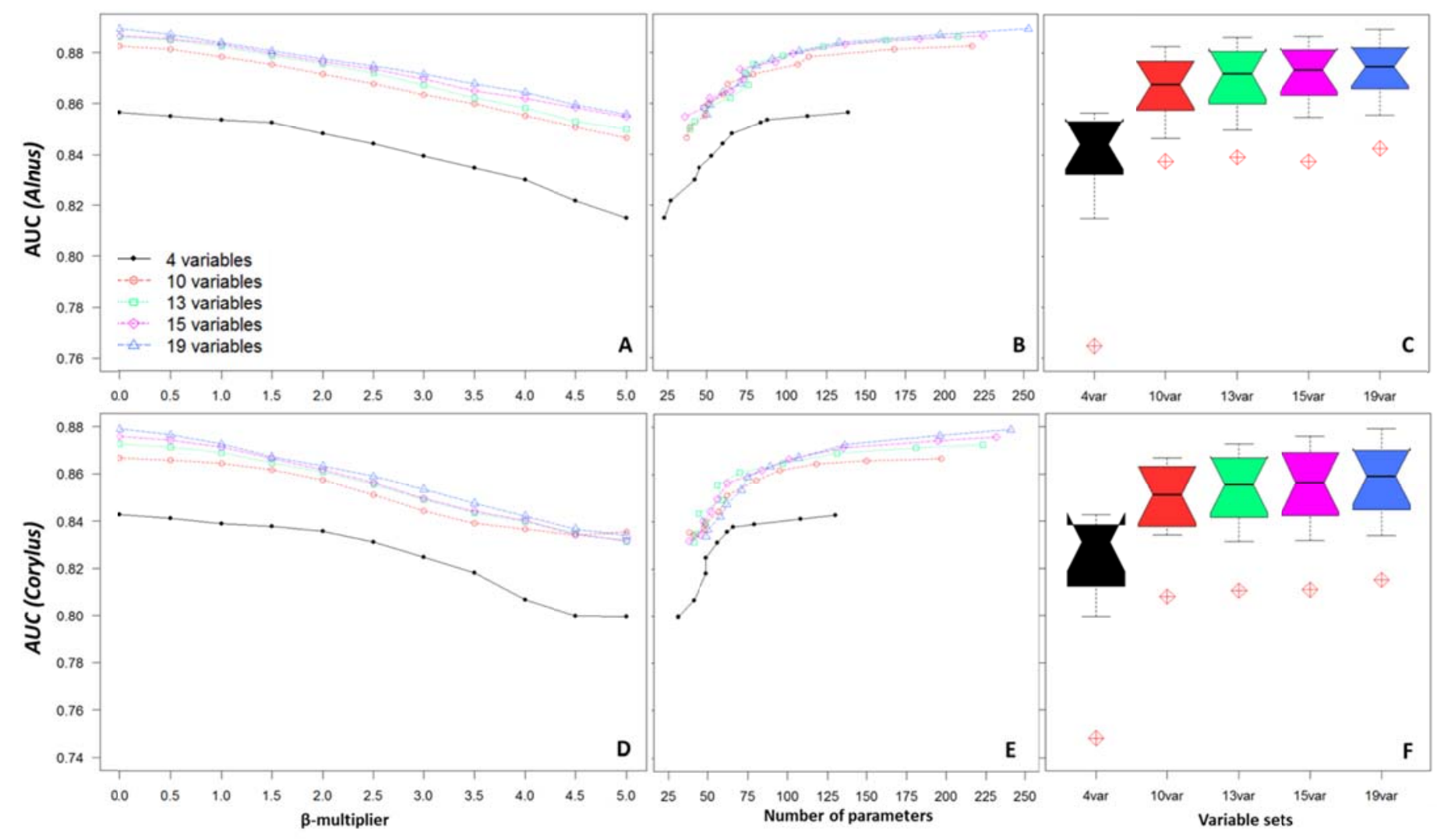

Fig. 3.2. AUC values for Maxent models under current conditions fitted with autofeatures, five sets of variables (different colours and symbols) and different $\beta$-multipliers for Alnus (A, B, and C) and Corylus (D, E, and F). The boxplots show AUC variability within each sets of variables $(\mathrm{C}, \mathrm{F})$. When only linear, product, and quadratic features are included in the model (autofeatures option deselected) AUC values remained constant, and are therefore plotted as red crosses in C and F.

Contrary to AUC, AICc values did not converge on the most complex model (Fig. 3.3). For both species, the best model according to AICc was the one run with autofeatures and highest number of variables (19), but differed in the optimal $\beta$-multiplier. The best model for Alnus was obtained when the $\beta$-multiplier equaled 2.5 , resulting in 81 parameters, while the default $\beta$-multiplier $(\beta=1)$ produced 133 parameters (Fig. 3.3A and $\mathrm{B}$ ). The best model for Corylus was at $\beta$-multiplier equal 1.5 , resulting in an intermediate number of 107 parameters, whereas the default $\beta$-multiplier $(\beta=1)$ produced 136 parameters (Fig. 3.3D and E). 


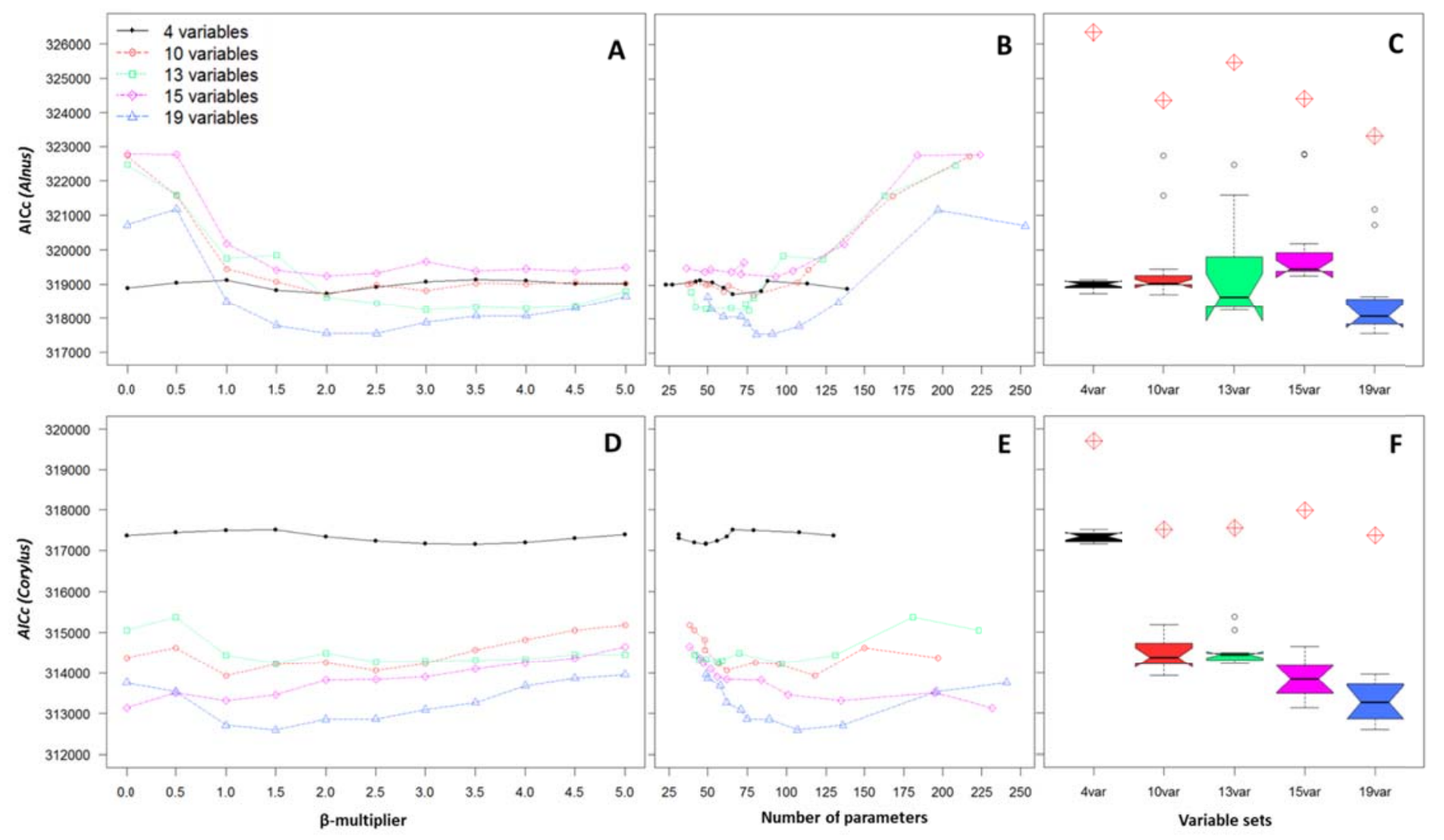

Fig. 3.3. AICc values for Maxent models under current conditions fitted with autofeatures, different sets of variables and $\beta$ multipliers for Alnus (A, B, and C) and Corylus (D, E, and F). The boxplots show AICc variability witthin each variable sets $(\mathrm{C}$ and $\mathrm{F})$. When only linear, product and quadratic features are included in the model (autofeatures option deselected) AICc values remained constant, and are therefore plotted as red crosses in $\mathrm{C}$ and F. Empty circles indicate outliers.

Both AUC and AICc values were constant across $\beta$-multipliers when only LQP features were allowed in the models, being only affected by the number of variables.

The projected suitable areas for the best models selected according to AUC and AICc showed similar patterns (Figs. G1 and G2). However, the models with lowest AICc tended to predict higher suitability values in each pixel than models with the highest AUC (Figs. G1, C and F).

\subsubsection{Evaluation of mid-Holocene projections}

The results for both species were similar under both OA-GCMs (Fig. 3.4 and Fig. E1 for MIROC and Figs. F1-F2 for CCSM), with no significant differences in mean AUC values (Student's $t$-test, $n=220, t=-1.335, p$-value $=0.183$ ) nor in the correlation values between pollen percentages and the suitability index of the models $(n=220, t=-0.303, p$ - 
value $=0.762$ ). Hence, we report the results for MIROC in the rest of the manuscript, while CCSM results are reported in Appendices F1-F2 for the sake of simplicity.

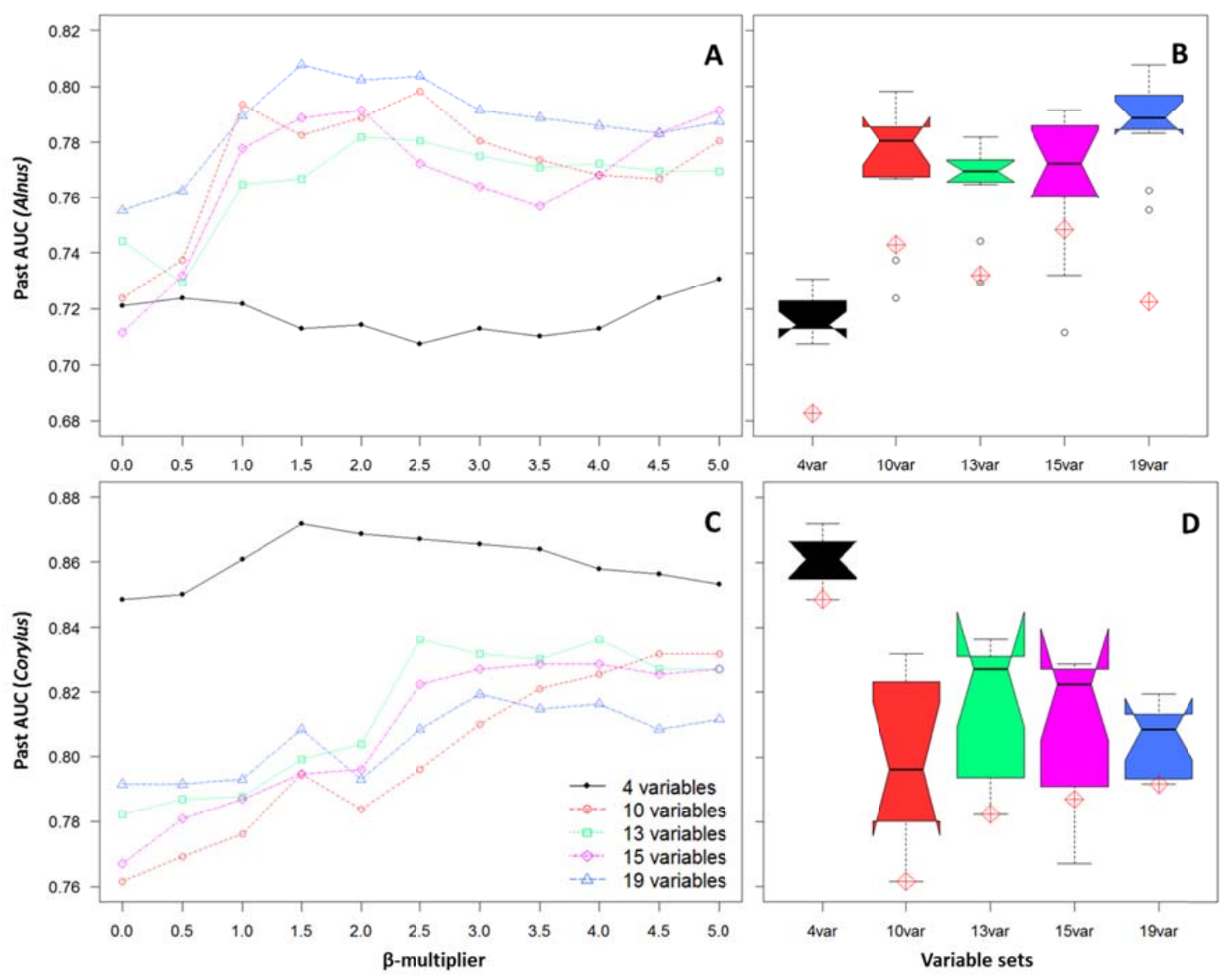

Fig. 3.4. AUC values for Maxent models projected to the mid-Holocene under MIROC General Circulation Model for Alnus (A and B) and Corylus (C and D) as a function of $\beta$-multiplier (A and C) and nested sets of variables (Bi and D). The boxplots show AUC variability within each variable sets (B and $\mathrm{C}$ ). When only linear, product and quadratic features are included in the model (autofeatures option deselected) AUC values remained constant, and are therefore plotted as red crosses in B and D. Empty circles indicate outliers.

AUC values for mid-Holocene projections evaluated with pollen data decreased slightly relative to the tests with current occurrences (Fig. 3.4). AUC varied from 0.663 to 0.808 $(0.741 \pm 0.035)$ for Alnus, and from 0.762 to $0.872(0.823 \pm 0.021)$ for Corylus. The highest AUC for Alnus was obtained with 19 variables, autofeatures, and $\beta$-multiplier equal to 1.5 , whereas for Corylus, it was obtained with four variables, autofeatures, and $\beta$-multiplier equal 1.5 (Fig. 3.5). AUC generally increased with increasing $\beta$-multipliers (Fig. 3.4), with the exception of models with 4 variables, which showed constant values for all $\beta$-multipliers. In the case of Alnus, all the models (except those with four variables) reached a maximum at 
$\beta=1.5-2.5$ and then slightly decreased, whereas for Corylus, all the models (except those with four variables) stabilized at $\beta \sim 3$.

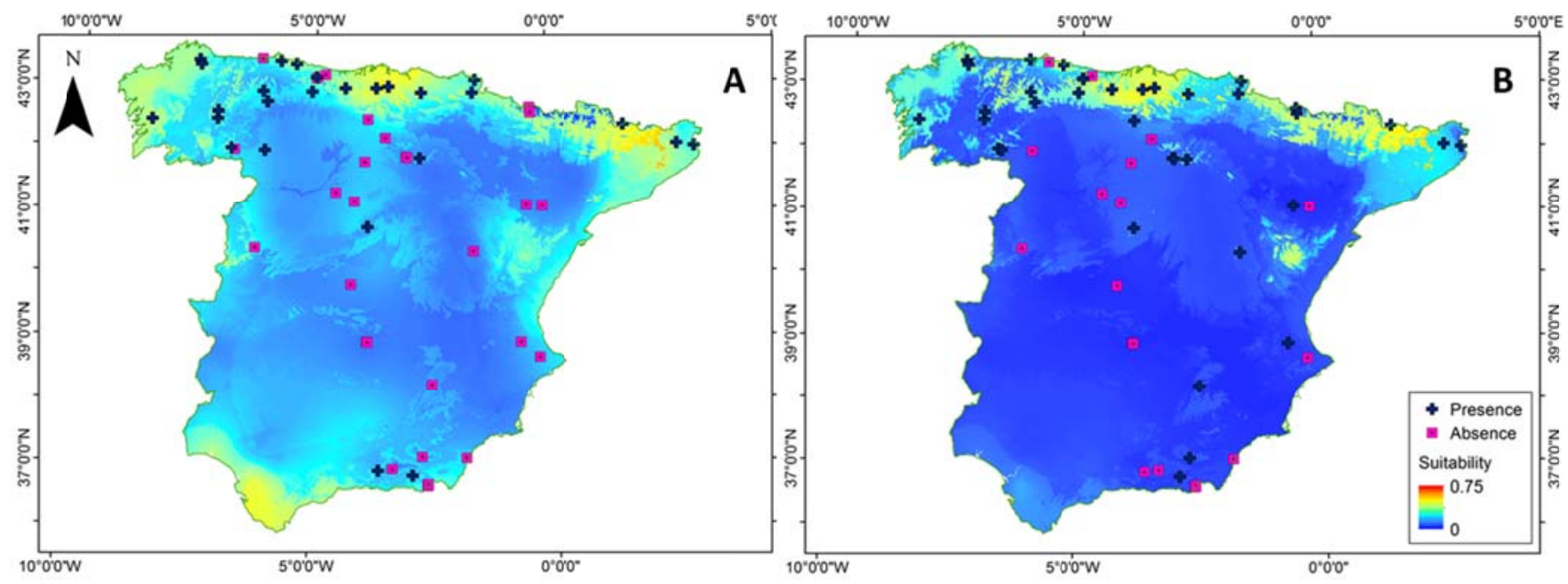

Fig. 3.5. Projections to the mid-Holocene in Spain of the best Maxent models according to the correlation between fossil pollen percentage and the suitability predicted by the models under CCSM General Circulation Model: presences (blue crosses) and absences (pink squares) for Alnus (A) and Corylus (B). The best model was the one with autofeatures, 10 variables and $\beta$-multiplier $=2.5$ for Alnus $(\mathrm{A})$ and the one with autofeatures, 13 variables and $\beta$-multiplier $=2.5$ for Corylus (B). The predicted suitability of the species in the area is displayed in a color gradient: red indicates high suitability and blue indicates low suitability.

The effect of model complexity tested against pollen percentages was similar to that described for AUC, except for the models of Corylus run with four variables (Figs. E1 and F2). Alnus models reached a maximum at $\beta=1.5-2.5$ and then decreased, whereas Corylus models stabilized at $\beta=\sim 2.5$. Similar to the evaluation with current data, the past AUC and the correlation values were the same along all the $\beta$-multipliers used when only LQP features were allowed in the models (Fig. 3.4B and D and Fig. E1, B and D).

\subsection{DISCUSSION}

The complexity of SDMs affects both model performance and the area predicted as suitable (Warren and Seifert, 2011 and Merow et al., 2014). Even when complex models show high performance predicting current distributions, they may produce poor predictions at new sites or different time periods (Warren et al., 2014). The poor transferability of complex correlative models could be a consequence of not capturing the species niche correctly by fitting the models too closely to the training data (overfitting) and preventing them from generalizing well (Warren et al., 2014). Assessing the effects of complexity in the transferability of correlative SDMs predictions is still fundamental given their broad implementation. 


\subsubsection{Effects of complexity in current and past species distributions}

As expected, we found that complex models performed well under current conditions. The best models according to the AUC for predicting current distributions were the most complex, reflecting that AUC does not consider model complexity nor goodness-of-fit (Lobo et al., 2008 and Warren and Seifert, 2011). In contrast, using the AICc and thus selecting the model by balancing overparameterization and model fit, resulted in the selection of models with less parameters (Fig. 3.3), which had slightly lower AUC (Fig. 3.2). Furthermore, the AICcselected models showed better cross-time transferability than AUC-selected models, with the former resulting in higher AUCs and correlation values when hindcasted. Thus, while the more complex models performed well under current conditions, they performed poorly when transferred in time to mid-Holocene climatic conditions (Fig. 3.4 and Figs. E1, F1 and F2).

The effects of model complexity were also apparent as geographic differences in the predicted current distribution of each species (Figs. G1-G2). For instance, the less complex AICc-selected models predicted a wider potential distribution for both species than the overfitted AUC-selected models. However, these differences varied across regions (Figs. G1G2). For example, AUC-selected model predictions were narrower in the northern parts of the distribution for both species, although this trend was not as clear in the Iberian Peninsula, especially in the binary predictions (Fig. G2).

The two independent paleobotanical validations used (past AUC using pollen thresholds and correlation using pollen percentages) overall led to the same trends. Selecting a threshold to estimate local species presence from pollen percentage is complex due to the lack of agreement in the percentage that could be considered as presence for a species in a pollen core (Lisitsyna et al., 2011). However, since the percentage and threshold analyses produced similar results, the threshold selection did not introduce bias.

Our results are thus in line with Warren et al. (2014), who found that model complexity strongly impacted both the modeled niche breadth and the projected suitability under future climate scenarios. Complex models calibrated on current conditions may thus overestimate the reduction of environmental suitability under climate change. As correlative SDMs are increasingly used as a tool to identify future suitable areas for hosting species (Araújo et al., 2011) such erroneous projections can have strong consequences in conservation plans and management strategies. 


\subsubsection{How do Maxent settings affect model complexity?}

Our results show that the factors most affecting Maxent model complexity are primarily the features classes included in the model, second the number of environmental predictors, and finally the $\beta$-multiplier selected (Fig. 3.3, and Table B1).

In terms of model performance, the feature types had a much larger effect than the number of variables or the $\beta$-multiplier (Fig. 3.2 and Fig. 3.4 and Figs. F1-F2). This is because forcing the model to use only LQP features heavily restricted the number of parameters allowed in the model (Table B1). In current projections, the AUC-selected and AICc-selected models agreed in the use of autofeatures as well as AUC in hindcasted models. Thus, in both present and past times, autofeatures were the option with greatest predictive performance. In contrast, Syfert et al. (2013) found that the choice of feature types had relatively minor effects on model performance when compared to the correction for sampling bias, and suggested that the autofeatures may be capturing local idiosyncratic effects rather than broad physiological responses of the species. They recommended fitting simple features like linear and quadratic and use them when they present similar performance values than with the autofeatures option (Syfert et al., 2013). Furthermore, Shcheglovitova and Anderson (2013) stated that it is possible to achieve models that outperform those obtained with default settings by coupling complex features with higher regularization to ensure that the model has a low number of parameters. However, in our study the number of variables had a greater effect than the $\beta$ multiplier. Too few variables could lead to under-parameterization and thus a poor representation of the full ecological range of the species (Synes and Osborne, 2011 and Syfert et al., 2013) as observed in our results of both species in the 4 variable model set.

Finally, the $\beta$-multiplier also had some influence on model performance and crosstemporal predictions. We found that the $\beta$-multiplier selected as the best compromise between performance and overprediction was higher than the default $(\beta=1)$, in accordance with former studies (Anderson and González, 2011, Muscarella et al., 2014, Radosavljevic and Anderson, 2014 and Shcheglovitova and Anderson, 2013). AICc-selected models had higher $\beta$-multiplier and thus less parameters than the default $\beta$-multiplier models, which were not the models with highest AUC as also observed by Muscarella et al. (2014). Decreasing AUC of the models with higher regularization multiplier has also been demonstrated in other studies (e.g. Shcheglovitova and Anderson, 2013). 


\subsubsection{The importance of species-specific tuning in Maxent models}

The two species studied obtained different optimal parameters for best cross-temporal transferability among them (same features, but different number of variables and betamultipliers) but higher (regularization parameter) than default Maxent settings in both species. Therefore, our findings jointly with other studies (e.g. Cao et al., 2013, Halvorsen et al., 2015, Muscarella et al., 2014 and Warren et al., 2014), highlight the importance of testing a range of parameter settings to see which perform best in each study case when using Maxent to predict the distribution of a species in different time periods.

\subsection{CONCLUSIONS AND FURTHER RECOMMENDATIONS}

Model complexity is a major issue that affects model performance and transferability and should be taken into account when projecting models across time. In general, Maxent users select default settings for complexity which, as we demonstrated in this study, can lead to the generation of over-complex models. In our study, complex models performed more poorly over time, indicating that standard methods for evaluating models that do not consider complexity (Fielding and Bell, 1997 and Lawson et al., 2014) cannot be recommended. We highly encourage conducting species-specific tuning when modeling distributions with Maxent to determine the best modeling options, as suggested by other authors (e.g. Halvorsen et al., 2015, Muscarella et al., 2014 and Shcheglovitova and Anderson, 2013). When paleoecological data are available, we recommend their use to make validations of SDMs projected in time. The use of this data allows us to understand the effects of model complexity through time and constitutes a reliable and independent dataset to test hindcasted models. Unfortunately, however, such data are scarce. When no paleoecological data are available and the aim of the study includes cross-temporal projections of species distributions, our results suggest that simpler models, with an intermediate complexity (intermediate number of variables and intermediate $\beta$-multiplier coupled with autofeatures option selected) will produce the best cross-temporal transferability. 


\subsection{SUPPLEMENTARY INFORMATION}

\section{Appendix A. Paleobotanical sites included in the analysis}

Table A1. Mid-Holocene pollen sites in Spain used in the analysis, including the location (longitude and latitude in WGS84), elevation, reference, site name, presence of pollen for the two studied species (Alnus and Corylus), and source of pollen data.. Mid-Holocene $(6,000 \pm 250 \mathrm{yr}$ cal BP) presence indicates if the pollen percentage of the species is equal or higher than the threshold ( $0.5 \%$ for Alnus and $1 \%$ for Corylus).

\begin{tabular}{|c|c|c|c|c|c|c|c|c|}
\hline Code & Longitude & Latitude & $\begin{array}{l}\text { Elevation } \\
\text { (masl) }\end{array}$ & References & Site name & $\begin{array}{l}\text { Alnus 6ky } \\
\text { BP presence }\end{array}$ & $\begin{array}{l}\text { Corylus } 6 \mathrm{ky} \\
\text { BP presence }\end{array}$ & $\begin{array}{c}\text { Source of } \\
\text { pollen data }\end{array}$ \\
\hline 1 & -1.550000 & 43.250000 & 500 & Peñalba, 1989; Peñalba, 1994 & Atxuri & Yes & Yes & EPD \\
\hline 2 & 2.756389 & 42.135278 & 175 & Pérez-Obiol and Julia, 1994 & Banyoles & Yes & Yes & EPD \\
\hline 3 & -2.708611 & 37.233611 & 1900 & Carrión et al., 2007 & Baza & No & Yes & Paper \\
\hline 4 & -7.552500 & 43.498333 & 1039 & Ramil-Rego et al., 1998 & $\begin{array}{l}\text { Chan Do } \\
\text { Lamoso }\end{array}$ & Yes & Yes & Paper \\
\hline 5 & -4.989444 & 43.282778 & 834 & Ruíz-Zapata et al., 2001 & Comella & Yes & Yes & $\begin{array}{l}\text { Paleodiversit } \\
\text { as }\end{array}$ \\
\hline 6 & -4.364167 & 43.116667 & 1320 & Mariscal, 1983 & $\begin{array}{l}\text { Cueto de la } \\
\text { Avellanosa }\end{array}$ & Yes & Yes & EPD \\
\hline 7 & -5.083333 & 43.050000 & 1500 & García-Rovés, 2007 & $\begin{array}{l}\text { Dolina de } \\
\text { Polvoredo }\end{array}$ & Yes & Yes & $\begin{array}{c}\text { Paleodiversit } \\
\text { as }\end{array}$ \\
\hline 8 & -3.506944 & 42.341944 & 1033 & Allué and Euba, 2008 & El Mirador & No & No & $\begin{array}{c}\text { Paleodiversit } \\
\text { as }\end{array}$ \\
\hline 9 & -0.383333 & 42.800000 & 1802 & $\begin{array}{c}\text { González-Sampériz et al., } \\
\text { 2004a; González-Sampériz et } \\
\text { al., } 2006\end{array}$ & El Portalet & No & Yes & $\begin{array}{l}\text { Author } \\
\text { contribution }\end{array}$ \\
\hline 10 & -3.935000 & 41.956667 & 885 & Franco-Múgica et al., 2001 & $\begin{array}{l}\text { Espinosa de } \\
\text { Cerrato }\end{array}$ & No & No & Paper \\
\hline 11 & -2.904722 & 36.931667 & 1530 & Carrión et al., 2003 & Gádor & Yes & Yes & Paper \\
\hline 12 & -0.500000 & 41.250000 & 260 & Davis and Stevenson, 2007 & $\begin{array}{c}\text { Hoya del } \\
\text { Castillo }\end{array}$ & No & Yes & EPD \\
\hline 13 & -2.750000 & 42.023889 & 1780 & Gil García et al., 2002 & Hoyos de Iregua & Yes & Yes & Paper \\
\hline 14 & -3.879167 & 42.633333 & 950 & $\begin{array}{l}\text { Muñoz Sobrino et al., 1996; } \\
\text { Ramil-Rego et al., } 1998\end{array}$ & La Piedra & No & Yes & Paper \\
\hline 15 & -6.136389 & 43.043333 & 1570 & $\begin{array}{l}\text { McKeever, 1984; Allen et al., } \\
1996\end{array}$ & Lago de Ajo & Yes & Yes & EPD \\
\hline 16 & -4.992222 & 43.272222 & 1070 & $\begin{array}{c}\text { Menéndez Amor, 1975; Ruiz } \\
\text { Zapata et al., 2001; Moreno et } \\
\text { al., 2011 }\end{array}$ & Lago Enol & No & Yes & $\begin{array}{l}\text { Author } \\
\text { contribution }\end{array}$ \\
\hline 17 & -6.040278 & 42.880833 & 1850 & García-Rovés, 2007 & Laguillín & Yes & Yes & $\begin{array}{l}\text { Paleodiversit } \\
\text { as }\end{array}$ \\
\hline 18 & -6.791111 & 42.133889 & 1608 & $\begin{array}{c}\text { Menéndez Amor and } \\
\text { Florschütz, 1961; Allen et al., } \\
1996\end{array}$ & $\begin{array}{l}\text { Laguna de la } \\
\text { Roya }\end{array}$ & Yes & Yes & EPD \\
\hline 19 & -2.509444 & 38.389167 & 1320 & Carrión, 2002 & Laguna de Siles & No & Yes & Paper \\
\hline 20 & -0.166667 & 41.233333 & 150 & $\begin{array}{c}\text { Stevenson et al., 1991; Valero- } \\
\text { Garcés et al., 2000b } \\
\end{array}$ & $\begin{array}{c}\text { Laguna Salada } \\
\text { Chiprana }\end{array}$ & No & No & EPD \\
\hline 21 & -6.171667 & 43.561944 & 127 & $\begin{array}{l}\text { López-Merino et al., 2006; } \\
\text { López-Merino, } 2009\end{array}$ & Las Dueñas & No & Yes & $\begin{array}{l}\text { Author } \\
\text { contribution }\end{array}$ \\
\hline 22 & -3.045833 & 42.043333 & 1870 & $\begin{array}{l}\text { Sánchez-Goñi and Hannon, } \\
1999 \\
\end{array}$ & $\begin{array}{l}\text { Las Pardillas } \\
\text { Lake }\end{array}$ & No & Yes & EPD \\
\hline 23 & -7.113056 & 42.592222 & 1375 & Leira and Santos, 2002 & Lucenza & Yes & Yes & $\begin{array}{c}\text { Paleodiversit } \\
\text { as }\end{array}$ \\
\hline 24 & -5.768889 & 43.528889 & 200 & López-Merino, 2009 & Monte Areo & Yes & No & $\begin{array}{l}\text { Author } \\
\text { contribution }\end{array}$ \\
\hline 25 & -8.891389 & 42.060278 & 0 & Ramil-Rego et al., 1998 & Mougás & Yes & No & Paper \\
\hline 26 & -0.683333 & 39.066667 & 225 & $\begin{array}{l}\text { Carrión and Dupré, 1996; } \\
\text { Carrión and van Geel, } 1999\end{array}$ & Navarrés 3 & No & Yes & EPD \\
\hline 27 & -1.633333 & 40.516667 & 1650 & Stevenson, 2000 & $\begin{array}{c}\text { Ojos del } \\
\text { Tremedal }\end{array}$ & No & Yes & Paper \\
\hline
\end{tabular}




\begin{tabular}{|c|c|c|c|c|c|c|c|c|}
\hline 28 & -3.611944 & 37.005833 & 70 & Pons and Reille, 1988 & Padul & Yes & No & $\begin{array}{l}\text { Paleodiversit } \\
\quad \text { as }\end{array}$ \\
\hline 29 & -7.517307 & 43.433256 & 700 & Ramil-Rego et al., 1998 & Pena Vella & Yes & Yes & Paper \\
\hline 30 & -7.111111 & 42.705556 & 1330 & Ramil-Rego et al., 1998 & $\begin{array}{l}\text { Pozo do } \\
\text { Carballal }\end{array}$ & Yes & Yes & Paper \\
\hline 31 & -1.615000 & 43.047500 & 847 & Peñalba, 1989; Peñalba, 1994 & Puerto de Belate & Yes & Yes & EPD \\
\hline 32 & -3.441111 & 43.150556 & 920 & Peñalba, 1989; Peñalba, 1994 & $\begin{array}{l}\text { Puerto de Los } \\
\text { Tornos } \\
\end{array}$ & Yes & Yes & EPD \\
\hline 33 & -3.020556 & 42.030278 & 1470 & $\begin{array}{l}\text { Peñalba, 1989; Peñalba, 1994; } \\
\text { Peñalba et al., 1997; Ruiz } \\
\text { Zapata et al., 2002 }\end{array}$ & $\begin{array}{l}\text { Quintanar de la } \\
\text { Sierra }\end{array}$ & No & Yes & EPD \\
\hline 34 & -3.863056 & 40.911667 & 1113 & $\begin{array}{c}\text { Franco-Múgica et al., 1995; } \\
\text { Franco-Múgica, 1998; Ruiz- } \\
\text { Zapata, 2007a; Ruiz-Zapata, } \\
\text { 2007b; Ruiz-Zapata, 2008 }\end{array}$ & Rascafría & Yes & Yes & Paper \\
\hline 35 & 1.633333 & 42.483333 & 2390 & $\begin{array}{c}\text { Ejarque, 2010; Ejarque et al., } \\
2010\end{array}$ & Riu del Orris & Yes & Yes & Paper \\
\hline 36 & -2.716667 & 43.050000 & 625 & Peñalba, 1989; Peñalba, 1994 & Saldropo & Yes & Yes & EPD \\
\hline 37 & -2.606944 & 36.773611 & 0 & $\begin{array}{c}\text { Yll et al., 1995; Pantaleón- } \\
\text { Cano, 1997; Pantaleón-Cano } \\
\text { et al., } 2003\end{array}$ & San Rafael & No & No & EPD \\
\hline 38 & -6.716667 & 42.116667 & 1050 & $\begin{array}{c}\text { Hannon, 1985; Turner and } \\
\text { Hannon, 1988, Allen et al., } \\
1996\end{array}$ & Sanabria Marsh & No & Yes & EPD \\
\hline 39 & 3.121460 & 42.080834 & 33 & Parra et al., 2005 & Sobrestany & Yes & Yes & $\begin{array}{l}\text { Paleodiversit } \\
\text { as }\end{array}$ \\
\hline 40 & -0.368611 & 42.724167 & 1668 & Montserrat-Martí, 1992 & Tramacastilla & No & Yes & $\begin{array}{c}\text { Paleodiversit } \\
\text { as }\end{array}$ \\
\hline 41 & -5.433333 & 43.487500 & 0 & $\begin{array}{c}\text { García-Antón et al., 2006; } \\
\text { García-Amorena et al., 2008 }\end{array}$ & Villaviciosa & Yes & Yes & Paper \\
\hline 42 & -3.700556 & 43.121389 & 1160 & Mariscal, 1989 & $\begin{array}{l}\text { Puerto de las } \\
\text { Estaces de } \\
\text { Trueba } \\
\end{array}$ & Yes & Yes & EPD \\
\hline 43 & -8.516667 & 42.533333 & 290 & López Merino et al., 2012 & PRD-4 & Yes & Yes & $\begin{array}{c}\text { Author } \\
\text { contribution }\end{array}$ \\
\hline 44 & -1.82361111 & 37.2083333 & 4 & $\begin{array}{c}\text { Yll et al., 1995; Pantaleón- } \\
\text { Cano, 1997; Pantaleón-Cano } \\
\text { et al., } 2003 \\
\end{array}$ & Antas & No & No & $\begin{array}{l}\text { Paleodiversit } \\
\quad \text { as }\end{array}$ \\
\hline 45 & -2.58888889 & 36.7944444 & 5 & $\begin{array}{c}\text { Yll et al., 1994, 1995; } \\
\text { Pantaleón-Cano et al, 1997; } \\
2003\end{array}$ & Roquetas de Mar & No & No & EPD \\
\hline 46 & -3.86666667 & 39.0833333 & 615 & Dorado-Valiño et al., 2002 & Daimiel CC-17 & No & No & $\begin{array}{l}\text { Paleodiversit } \\
\quad \text { as }\end{array}$ \\
\hline 47 & -4.54444444 & 41.4594444 & 800 & García-Antón et al., 2011 & Camporredondo & No & No & Paper \\
\hline 48 & -4.14694444 & 41.32 & 860 & Franco-Múgica et al., 2005 & El Carrizal & No & No & Paper \\
\hline 49 & -4.2 & 39.9833333 & 520 & $\begin{array}{l}\text { Bueno et al., 2002; López- } \\
\text { Sáez et al., } 2009\end{array}$ & Valle de Huecas & No & No & $\begin{array}{l}\text { Paleodiversit } \\
\quad \text { as }\end{array}$ \\
\hline 50 & -3.855 & 39.0725 & 600 & García Antón et al., 1986 & $\begin{array}{l}\text { Castillo de } \\
\text { Calatrava }\end{array}$ & No & No & $\begin{array}{l}\text { Paleodiversit } \\
\quad \text { as }\end{array}$ \\
\hline 51 & -3.33333333 & 37.0333333 & 3020 & Anderson et al., 2011 & $\begin{array}{l}\text { Laguna de Río } \\
\text { Seco }\end{array}$ & No & No & $\begin{array}{l}\text { Paleodiversit } \\
\text { as }\end{array}$ \\
\hline 52 & -0.29805556 & 38.8158333 & 650 & González-Sampériz, 1998 & En Pardo & No & No & $\begin{array}{l}\text { Paleodiversit } \\
\text { as }\end{array}$ \\
\hline 53 & -4.80083333 & 43.3258333 & 325 & Uzquiano, 1992 & Los Canes & No & No & $\begin{array}{l}\text { Paleodiversit } \\
\text { as }\end{array}$ \\
\hline 54 & -6.20972222 & 40.5466667 & 1100 & Morales et al., 2013 & El Maíllo & No & No & $\begin{array}{c}\text { Author } \\
\text { contribution }\end{array}$ \\
\hline 55 & -6.06666666 & 42.1166667 & 780 & $\begin{array}{l}\text { Morales and García Antón, } \\
2014\end{array}$ & $\begin{array}{l}\text { Ayoó de } \\
\text { Vidriales }\end{array}$ & Yes & No & $\begin{array}{c}\text { Author } \\
\text { contribution }\end{array}$ \\
\hline
\end{tabular}




\section{References:}

Allen, J.R.M., Huntley, B., Watts, W.A., 1996. The vegetation and climate of northwest Iberia over the last 14,000 years. J. Quaternary Sci. 11, 125-147.

Allué, E, Euba, I., 2008. Los datos antracológicos de la secuencia neolítica de El Mirador (Atapuerca, Burgos): un estudio sobre el medio vegetal y la explotación de las especies vegetales leñosas. In: Hernández-Pérez MS, Soler Díaz JA, López Padilla JA (Eds), 2006. IV Congreso de Neolítico Peninsular. Museo Arqueológico de Alicante (MARQ), Alicante, pp 345-352.

Anderson, R.S., Jiménez-Moreno, G., Carrión, J.S., Pérez-Martínez, C., 2011. Postglacial history of alpine vegetation, fire, and climate from Laguna de Río Seco, Sierra Nevada, southern Spain. Quat. Sci. Rev. 30, 1615-1629.

Bueno, P., Barroso, R., Balbín, R., Campo, M., Etxeberría, F., González, A., Herrasti, L., Juan J., López, P., López-Sáez, J.A., Sánchez, B., 2002. Áreas habitacionales y áreas funerarias en el Neolítico de la cuenca interior del Tajo: la provincia de Toledo. Trabajos de Prehistoria 59 (2), 65-80.

Carrión, J.S., 2002. Patterns and processes of Late Quaternary environmental change in a montane region of southwestern Europe. Quat. Sci. Rev. 21, 2047-2066.

Carrión, J.S., Dupre, M., 1996. Late Quaternary vegetational history at Navarrés, Eastern Spain. A two core approach. New Phytol. 134, 177-191.

Carrión, J.S., Fuentes, N., González-Sampériz, P., Sánchez Quirante, L., Finlayson, J.C., Fernández, S., Andrade, A., 2007. Holocene environmental change in a montane region of southern Europe with a long history of human settlement. Quat. Sci. Rev. 26, 14551475 .

Carrión, J.S., Sánchez-Gómez, P., Mota, J.F., Y11, R., Chaín, C., 2003. Holocene vegetation dynamics, fire and grazing in the Sierra de Gádor, southern Spain. The Holocene 13, 839-849.

Carrión, J.S., Van Geel, B., 1999. Fine-resolution Upper Weichselian and Holocene palynological record from Navarrés (Valencia, Spain) and a discussion about factors of Mediterranean forest succession. Review Palaeobot. Palyno. 106, 209-236.

Davis, B.A.S., Stevenson, A.C., 2007. The 8.2 ka event and Early-Mid Holocene forests, fires and flooding in the Central Ebro Desert, NE Spain. Quat. Sci. Rev. 26, 1695-1712.

Dorado Valiño, M., Valdeolmillos Rodríguez, A., Ruiz Zapata, M.B., Gil García, M.J., de Bustamante Gutiérrez, I., 2002. Climatic changes since the Late-glacial/Holocene 
transition in La Mancha Plain (South-central Iberian Peninsula, Spain) and their incidence on Las Tablas de Daimiel marshlands. Quaternary Int. 93-94, 73-84.

Ejarque, A., 2010. Génesis y configuración microregional de un paisaje cultural pirenaico de alta montaña durante el holoceno: estudio polínico y de otros indicadores paleoambientales en el valle del Madriu-Perafita-Claror (Andorra). $\mathrm{PhD}$ Thesis. Universitat Rovira i Virgili.

Ejarque, A., Miras, Y., Riera, S., Palet, J.M., Orengo, H.A., 2010. Testing micro-regional variability in the Holocene shaping of high mountain cultural landscapes: a palaeoenvironmental case-study in the eastern Pyrenees. J. Archaeol. Sci. 37, 14681479 .

Franco-Múgica, F., 1995. Estudio palinológico de turberas holocenas en el Sistema Central: reconstrucción paisajística y acción antrópica. PhD Thesis. Universidad Autónoma, Madrid, 358 pp.

Franco Múgica, F., García-Antón, M., Maldonado-Ruiz, J., Morla-Juaristi, C., Sainz-Ollero, H., 2001. The Holocene history of Pinus forests in the Spanish Northern Meseta. The Holocene. 11(3), 343-358.

Franco-Múgica, F., García-Antón, M., Maldonado-Ruiz, J., Morla-Juaristi, C., Sainz-Ollero, H., 2005. Ancient pine forest on inland dunes in the Spanish northern meseta. Quaternary Res. 63, 1-14.

García-Amorena, I., Morla, C., Rubiales, J.M., Manzaneque, F.G., 2008. Taxonomic composition of the Holocene forests of the northern coast of Spain, as determined from their macroremains. The Holocene. 18, 819-829.

García-Antón, M., Franco-Múgica, F., Morla-Juaristi, C., Maldonado-Ruiz, J., 2011. The biogeographical role of Pinus forest on the Northern Spanish Meseta: a new Holocene sequence. Quat. Sci. Rev. 30, 757-768.

García Antón, M., Gil Romera, G., Pagés, J.L., Alonso Millán, A., 2006. The Holocene pollen record in the Villaviciosa Estuary (Asturias, North Spain). Palaeogeogr. Palaeoclimatol. Palaeoecol. 237, 280-292.

García-Antón, M., Morla, C., Ruiz Zapata, B., Sainz Ollero, H., 1986. Contribución al conocimiento del paisaje vegetal Holoceno en la submeseta sur Ibérica: análisis polínico de sedimentos higroturbosos en el Campo de Calatrava, Ciudad Real, España. pp 189203. In López Vera, F. (Ed) Quaternary Climate in Western Mediterranean. Universidad Autónoma, Madrid. 
García-Rovés, E., 2007. Dinámica de la Paleovegetación y cambios climáticos durante el Tardiglaciar y Holoceno en secuencias sedimentarías de la provincia de León. PhD Thesis, Universidad de León, León, Spain.

Gil García, M.J., Valiño, M.D., Rodríguez, A.V., Zapata, M.B.R., 2002. Late-glacial and Holocene palaeoclimatic record from Sierra de Cebollera (northern Iberian Range, Spain). Quaternary Int. 93-94, 13-18.

González-Sampériz P., 1998. Estudio palinológico de la Cueva de En Pardo (Planes, Alicante). Primeros resultados. Cuaternario y Geomorfología 12 (1-2), 45-61.

González-Sampériz, P., Valero-Garcés, B., Carrión, J.S., 2004 Was the Ebro valley a glacial refugium for temperate trees?. Anales de Biología. 26: 13-20.

González-Sampériz, P., Valero-Garcés, B.L., Moreno, A., Jalut, G., García-Ruiz, J.M., MartíBono, C., Delgado-Huertas, A., Navas, A., Otto, T., Dedoubat, J.J., 2006. Climate variability in the Spanish Pyrenees during the last 30,000 yr revealed by the El Portalet sequence. Quaternary Res. 66, 38-52.

Hannon, G.E., 1985. Late Quaternary vetetation of Sanabria Marsh, North West Spain. M Sc Thesis. Trinity College, Dublin, Ireland.

Leira, M., Santos, L., 2002. An early Holocene short climatic event in the northwest Iberian Peninsula inferred from pollen and diatoms. Quaternary Int. 93-94, 3-12.

López-Merino, L., 2009. Paleoambiente y antropización en Asturias durante el Holoceno. PhD Thesis. Universidad Autónoma de Madrid, Madrid.

López-Merino, L., López-Sáez, J.A., López García, P., 2006. Estudio palinológico de la turbera litoral holocena de Las Dueñas (Cudillero, Asturias, España). Revista Española de Micropaleontología. 38(2-3): 299-308.

López-Merino, L., Silva Sánchez, N., Kaal, J., López-Sáez, J.A., Martínez Cortizas, A., 2012. Post-disturbance vegetation dynamics during the Late Pleistocene and the Holocene: An example from NW Iberia. Global Planet. Change 92-93, 58-70.

López Sáez, J.A., López-Merino, L., Pérez Díaz, S., 2009. Historia de la vegetación y paleoambiente del Valle de Huecas. In Arqueología, medio ambiente y obras públicas: el Valle de Huecas (Huecas, Toledo). pp. 89-108. Anthropos.

Mariscal, B., 1983 Estudio polínico de la turbera del Cueto de la Avellanosa polaciones (Cantabria). VI Reunion do grupo espanol de traballo de Quaternario. Cuadernos do laboratorio xeloxico de laxe. 5: 205-226. 
Mariscal, B., 1989. Comparación palinológica entre una turbera de la cordillera central y unas turberas de la cordillera cantábrica. II. European Paleobot. conference. P. 28. Universidad Complutense Madrid.

McKeever, M., 1984. Comparative palynological studies of two lake sites in western Ireland and northwestern Spain. M Sc Thesis. Trinity College, Dublin, Ireland.

Menéndez Amor, J., 1975. Análisis esporo-polínico de los sedimentos turbosos de los lagos Enol y Ercina. Boletín de la Real Sociedad Española de Historia Natural Sección Geológica 1:311-313.

Menéndez Amor, J. Florschütz, F., 1961. Contribución al conocimiento de la historia de la vegetación en España durante el Cuaternario. Estudios Geológicos 17: 83-99.

Montserrat-Martí, J., 1992. Evolución Glaciar y Postglaciar del Clima y la Vegetación en la Vertiente sur del Pirineo: Estudio Palinológico. Monografías del Instituto Pirenaico de Ecología-CSIC, Zaragoza. 147pp.

Morales-Molino, C., García-Antón, M., 2014. Vegetation and fire history since the last glacial maximum in an inland area of the western Mediterranean Basin (Northern Iberian Plateau, NW Spain). Quaternary Res. 81, 63-77.

Morales-Molino, C., García-Antón, M., Postigo-Mijarra, J.M., Morla, C., 2013. Holocene vegetation, fire and climate interactions on the westernmost fringe of the Mediterranean Basin. Quat. Sci. Rev. 59, 5-17.

Moreno, A., López-Merino, L., Leira, M., Marco-Barba, J., González-Sampériz, P., ValeroGarcés, B.L., López-Sáez, J.A., Santos, L., Mata, P., Ito, E., 2009. Revealing the last 13,500 years of environmental history from the multiproxy record of a mountain lake (Lago Enol, northern Iberian Peninsula). J. Paleolimnol. 46, 327-349.

Muñoz Sobrino, C., Ramil-Rego, P., Delibes de Castro, G., Rojo, M., 1996. Datos paleobotánicos sobre la turbera de La Piedra (Páramo de Trozo, Burgos). pp 149-162. In Ramil-Rego, P. et al., (Eds) Biogeografía Pleistocena-Holocena de la Península Ibérica. Xunta de Galicia, Santiago de Compostela.

Pantaleón-Cano, J., 1997. Estudi palinologic de sediments litorals de la província d'Almeria. Transformacion del paisatge vegetal dins un territori semiarid. $\mathrm{PhD}$ thesis. Universitat Autònoma de Barcelona, Barcelona, Spain.

Pantaléon-Cano, J., Yll, E.-I., Pérez-Obiol, R., Roure, J.M., 2003. Palynological evidence for vegetational history in semi-arid areas of the western Mediterranean (Almería, Spain). The Holocene. 13, 109-119. 
Parra, I., Van Campo, E., Otto, T., 2005. Análisis palinológico y radiométrico del sondeo sobrestany. Nueve milenios de historia natural e impactos humanos sobre la vegetación del Alt Empordà. Empúries. 54, 33-44.

Peñalba, M.C., 1989. Dynamique de vegetation Tardiglaciaire et Holocene du centre-nord de l'Espagne d'après l'analyse pollinique. PhD Thesis. Université d'Aix-Marseille, Marseille, France.

Peñalba, M.C., 1994. The History of the Holocene Vegetation in Northern Spain from Pollen Analysis. J. Ecol. 82, 815-832.

Peñalba, M.C., Arnold, M., Guiot, J., Duplessy, J.C., de Beaulieu, J.L., 1997. Termination of the Last Glaciation in the Iberian Peninsula Inferred from the Pollen Sequence of Quintanar de la Sierra. Quaternary Res. 48, 205-214.

Pèrez-Obiol, R., Julià, R., 1994. Climatic Change on the Iberian Peninsula Recorded in a 30,000-Yr Pollen Record from Lake Banyoles. Quaternary Res. 41, 91-98.

Pons, A., Reille, M., 1988. The holocene- and upper pleistocene pollen record from Padul (Granada, Spain): A new study. Palaeogeogr. Palaeoclimatol. Palaeoecol. 66, 243-263.

Ramil-Rego, P., Muñoz-Sobrino, C., Rodríguez-Guitián, M., Gómez-Orellana, L., 1998. Differences in the vegetation of the North Iberian Peninsula during the last 16,000 years. Plant Ecol. 138, 41-62.

Ruiz Zapata, M.B., Farias, P., Jiménez Sánchez, M., Gil García, M.J., Dorado Valiño, M., Valdeolmillos Rodríguez, A. (2001a). Secuencia polínica de un depósito de la depresión de Comeya (Picos de Europa, Asturias): implicaciones paleoclimáticas. pp 379-389. In: Moreno Grau, S., Rendueles, B., Moreno Angosto, J.M. (Eds) XIII Simposio de la Asociación de Palinólogos de Lengua Española (APLE) Universidad Politécnica de Cartagena, Cartagena.

Ruiz Zapata, M.B., Gil García, M.J., Dorado-Valiño, M., Valdeolmillos Rodríguez, A., Vegas Salamanca, J., Pérez González, A., 2002. Clima y vegetación durante el pleistoceno superior y el holoceno en la Sierra de Neila (Sistema Ibérico noroccidental). Cuaternario y Geomorfología 16(1-4): 9-20.

Ruiz Zapata, M.B., Gómez González, C., Santisteban, J.I., Mediavilla, R., Domínguez, F., Gil García, M.J., López-Sáez, J.A., Vera, M.S., 2007. Reconstrucción paleoambiental y paleoclimática en el entorno del Valle del Lozoya: valoración del impacto humano. Pp 87-95 in Sextas Jornadas Científicas del Parque Natural de Peñalara y del Valle de El Paular.

Ruiz Zapata, M.B., Jiménez Sánchez, M., Farias, P., Gil García, M.J., Dorado Valiño, M., Valdeolmillos Rodríguez, A., 2001a. Registro palinológico de un depósito Holoceno del 
Parque Natural de Redes (Cordillera Cantábrica). pp 391-400. In: Moreno Grau, S., Rendueles, B., Moreno Angosto, J.M. (Eds) XIII Simposio de la Asociación de Palinólogos de Lengua Española (APLE) Universidad Politécnica de Cartagena, Cartagena.

Ruiz Zapata, M.B., Vegas, J., García Cortés, A., Gil García, M.J., Torres, T., Ortiz, J.E., Galán, L., Pérez-González, A., 2008. Comportamiento de la vegetación, durante el Último Máximo Glaciar, en la secuencia FU-1 (Laguna del maar de Fuentillejo, Campo de Calatrava, Ciudad Real). Polen. 18: 37-49.

Sánchez-Goñi, M.F.., Hannon, G.E., 1999. High-altitude vegetational pattern on the Iberian Mountain Chain (north-central Spain) during the Holocene. The Holocene. 9(1), 39-57.

Stevenson, A.C., 2000. The Holocene forest history of the Montes Universales, Teruel, Spain. The Holocene 10, 603-610.

Stevenson, A., Macklin, M., Benavente, J., Navarro, C., Passmore, D., Davis, B.A.S., 1991. Cambios ambientales durante el Holoceno en el Valle del Ebro: sus implicaciones arqueológicas. Cuaternario y Geomorfología 5: 149-164.

Turner, C., Hannon, G.E., 1988. Vegetational Evidence for Late Quaternary Climatic Changes in Southwest Europe in Relation to the Influence of the North Atlantic Ocean. Philos. Trans. R. Soc. Lond. 318, 451-485.

Uzquiano, P., 1992. Recherches anthracologiques dans le sécteur Pyréneo-Cantabrique (Pays Basque, Cantabria et Asturias): Environnements et rélations homme-milieu au Pléistocène supérieur et début de l'Holocène. Tesis doctoral. Environnements et Archéologie. Universidad de Montpellier II, 400 pp.

Valero-Garcés, B.L., Navas, A., Machin, J., Stevenson, T., Davis, B., 2000. Responses of a Saline Lake Ecosystem in a Semiarid Region to Irrigation and Climate Variability. AMBIO. 29, 344-350.

Y1l, E. I., Pérez Obiol, R., Pantaleón-Cano, J., \& Roure, J.M., 1995. Dinámica del paisaje vegetal en la vertiente mediterránea de la Península Ibérica e Islas Baleares desde el Tardiglaciar hasta el presente. Reconstrucción de Paleoambientes y cambios climáticos durante el Cuaternario, 3, 319-328. CSIC, Madrid, Spain.

Y1l, E.I., Roure, J.M., Pantaleón-Cano, J., Pérez-Obiol, R., 1994. Análisis polínico de una secuencia holocénica en Roquetas de Mar (Almería). pp 189-198 in Mateu, I., Dupre, M., Guemes, J., Burgaz, M.E. (Eds.). Trabajos de palinología básica y aplicada. Universitat de Valencia, Valencia, Spain. 


\section{Appendix B. Number of variables, type of features and number of parameters included in the models.}

Table B1. Number of parameters included in the models for Alnus and Corylus. These numbers of parameters result from the number of environmental variables, the combination allowed for features (transformations of environmental variables) and the $\beta$-multiplier. AF means Autofeatures.

\begin{tabular}{|c|c|c|c|c|c|c|c|c|c|c|c|}
\hline $\begin{array}{c}\text { Model } \\
\text { number }\end{array}$ & $\begin{array}{c}\text { Features } \\
\text { type }\end{array}$ & $\begin{array}{c}\mathbf{N}^{\mathbf{0}} \\
\text { variables }\end{array}$ & $\begin{array}{c}\text { b- } \\
\text { multiplier }\end{array}$ & $\begin{array}{c}\mathbf{N}^{\mathbf{2}} \\
\text { Parameters } \\
\text { Alnus } \\
\end{array}$ & $\begin{array}{c}\mathbf{N}^{\mathbf{1}} \\
\text { Parameters } \\
\text { Corylus } \\
\end{array}$ & $\begin{array}{c}\text { Model } \\
\text { number }\end{array}$ & $\begin{array}{c}\text { Features } \\
\text { type }\end{array}$ & $\begin{array}{c}\mathrm{N}^{\mathbf{0}} \\
\text { variables }\end{array}$ & $\begin{array}{c}\text { b- } \\
\text { multiplier }\end{array}$ & \begin{tabular}{|c|}
$\mathbf{N}^{\mathbf{0}}$ \\
Parameters \\
Alnus \\
\end{tabular} & \begin{tabular}{|c|}
$\mathbf{N}^{\mathbf{0}}$ \\
Parameters \\
Corylus \\
\end{tabular} \\
\hline 1 & With AF & 4 & 0 & 139 & 130 & 56 & Without AF & 4 & 0 & 9 & 6 \\
\hline 2 & With AF & 4 & 0.5 & 113 & 108 & 57 & Without AF & 4 & 0.5 & 9 & 6 \\
\hline 3 & With AF & 4 & 1 & 88 & 79 & 58 & Without AF & 4 & 1 & 9 & 6 \\
\hline 4 & With AF & 4 & 1.5 & 84 & 66 & 59 & Without AF & 4 & 1.5 & 9 & 6 \\
\hline 5 & With AF & 4 & 2 & 66 & 62 & 60 & Without AF & 4 & 2 & 9 & 6 \\
\hline 6 & With AF & 4 & 2.5 & 60 & 56 & 61 & Without AF & 4 & 2.5 & 9 & 6 \\
\hline 7 & With AF & 4 & 3 & 53 & 49 & 62 & Without AF & 4 & 3 & 9 & 6 \\
\hline 8 & With AF & 4 & 3.5 & 45 & 49 & 63 & Without AF & 4 & 3.5 & 9 & 6 \\
\hline 9 & With AF & 4 & 4 & 42 & 41 & 64 & Without AF & 4 & 4 & 9 & 6 \\
\hline 10 & With AF & 4 & 4.5 & 27 & 31 & 65 & Without AF & 4 & 4.5 & 9 & 6 \\
\hline 11 & With AF & 4 & 5 & 23 & 31 & 66 & Without AF & 4 & 5 & 9 & 6 \\
\hline 12 & With AF & 10 & 0 & 217 & 197 & 67 & Without AF & 10 & 0 & 12 & 13 \\
\hline 13 & With AF & 10 & 0.5 & 168 & 150 & 68 & Without AF & 10 & 0.5 & 12 & 13 \\
\hline 14 & With AF & 10 & 1 & 114 & 118 & 69 & Without AF & 10 & 1 & 12 & 13 \\
\hline 15 & With AF & 10 & 1.5 & 107 & 95 & 70 & Without AF & 10 & 1.5 & 12 & 13 \\
\hline 16 & With AF & 10 & 2 & 79 & 80 & 71 & Without AF & 10 & 2 & 12 & 13 \\
\hline 17 & With AF & 10 & 2.5 & 63 & 62 & 72 & Without AF & 10 & 2.5 & 12 & 13 \\
\hline 18 & With AF & 10 & 3 & 60 & 57 & 73 & Without AF & 10 & 3 & 12 & 13 \\
\hline 19 & With AF & 10 & 3.5 & 51 & 48 & 74 & Without AF & 10 & 3.5 & 12 & 13 \\
\hline 20 & With AF & 10 & 4 & 49 & 48 & 75 & Without AF & 10 & 4 & 12 & 13 \\
\hline 21 & With AF & 10 & 4.5 & 39 & 41 & 76 & Without AF & 10 & 4.5 & 12 & 13 \\
\hline 22 & With AF & 10 & 5 & 37 & 38 & 77 & Without AF & 10 & 5 & 12 & 13 \\
\hline 23 & With AF & 13 & 0 & 208 & 223 & 78 & Without AF & 13 & 0 & 17 & 15 \\
\hline 24 & With AF & 13 & 0.5 & 163 & 181 & 79 & Without AF & 13 & 0.5 & 17 & 15 \\
\hline 25 & With AF & 13 & 1 & 123 & 131 & 80 & Without AF & 13 & 1 & 17 & 15 \\
\hline 26 & With AF & 13 & 1.5 & 98 & 97 & 81 & Without AF & 13 & 1.5 & 17 & 15 \\
\hline 27 & With AF & 13 & 2 & 79 & 70 & 82 & Without AF & 13 & 2 & 17 & 15 \\
\hline 28 & With AF & 13 & 2.5 & 74 & 56 & 83 & Without AF & 13 & 2.5 & 17 & 15 \\
\hline 29 & With AF & 13 & 3 & 76 & 59 & 84 & Without AF & 13 & 3 & 17 & 15 \\
\hline 30 & With AF & 13 & 3.5 & 65 & 44 & 85 & Without AF & 13 & 3.5 & 17 & 15 \\
\hline 31 & With AF & 13 & 4 & 49 & 49 & 86 & Without AF & 13 & 4 & 17 & 15 \\
\hline 32 & With AF & 13 & 4.5 & 42 & 42 & 87 & Without AF & 13 & 4.5 & 17 & 15 \\
\hline 33 & With AF & 13 & 5 & 39 & 41 & 88 & Without AF & 13 & 5 & 17 & 15 \\
\hline 34 & With AF & 15 & 0 & 224 & 232 & 89 & Without AF & 15 & 0 & 19 & 15 \\
\hline 35 & With AF & 15 & 0.5 & 184 & 195 & 90 & Without AF & 15 & 0.5 & 19 & 15 \\
\hline 36 & With AF & 15 & 1 & 137 & 135 & 91 & Without AF & 15 & 1 & 19 & 15 \\
\hline 37 & With AF & 15 & 1.5 & 104 & 101 & 92 & Without AF & 15 & 1.5 & 19 & 15 \\
\hline 38 & With AF & 15 & 2 & 93 & 84 & 93 & Without AF & 15 & 2 & 19 & 15 \\
\hline
\end{tabular}




\begin{tabular}{|c|c|c|c|c|c|}
\hline 39 & With AF & 15 & 2.5 & 71 & 62 \\
\hline 40 & With AF & 15 & 3 & 73 & 56 \\
\hline 41 & With AF & 15 & 3.5 & 65 & 52 \\
\hline 42 & With AF & 15 & 4 & 52 & 47 \\
\hline 43 & With AF & 15 & 4.5 & 48 & 45 \\
\hline 44 & With AF & 15 & 5 & 36 & 38 \\
\hline 45 & With AF & 19 & 0 & 253 & 241 \\
\hline 46 & With AF & 19 & 0.5 & 197 & 196 \\
\hline 47 & With AF & 19 & 1 & 133 & 136 \\
\hline 48 & With AF & 19 & 1.5 & 108 & 107 \\
\hline 49 & With AF & 19 & 2 & 91 & 89 \\
\hline 50 & With AF & 19 & 2.5 & 81 & 75 \\
\hline 51 & With AF & 19 & 3 & 75 & 71 \\
\hline 52 & With AF & 19 & 3.5 & 71 & 62 \\
\hline 53 & With AF & 19 & 4 & 60 & 58 \\
\hline 54 & With AF & 19 & 4.5 & 52 & 50 \\
\hline 55 & With AF & 19 & 5 & 50 & 49 \\
\hline
\end{tabular}

\begin{tabular}{|c|c|c|c|c|c|}
94 & Without AF & 15 & 2.5 & 19 & 15 \\
\hline 95 & Without AF & 15 & 3 & 19 & 15 \\
\hline 96 & Without AF & 15 & 3.5 & 19 & 15 \\
\hline 97 & Without AF & 15 & 4 & 19 & 15 \\
\hline 98 & Without AF & 15 & 4.5 & 19 & 15 \\
\hline 99 & Without AF & 15 & 5 & 19 & 15 \\
\hline 100 & Without AF & 19 & 0 & 25 & 20 \\
\hline 101 & Without AF & 19 & 0.5 & 25 & 20 \\
\hline 102 & Without AF & 19 & 1 & 25 & 20 \\
\hline 103 & Without AF & 19 & 1.5 & 25 & 20 \\
\hline 104 & Without AF & 19 & 2 & 25 & 20 \\
\hline 105 & Without AF & 19 & 2.5 & 25 & 20 \\
\hline 106 & Without AF & 19 & 3 & 25 & 20 \\
\hline 107 & Without AF & 19 & 3.5 & 25 & 20 \\
\hline 108 & Without AF & 19 & 4 & 25 & 20 \\
\hline 109 & Without AF & 19 & 4.5 & 25 & 20 \\
\hline 110 & Without AF & 19 & 5 & 25 & 20 \\
\hline
\end{tabular}




\section{Appendix C. Multivariate similarity surface (MESS) for comparing similarity between current calibration range and mid-Holocene climate in the study area.}
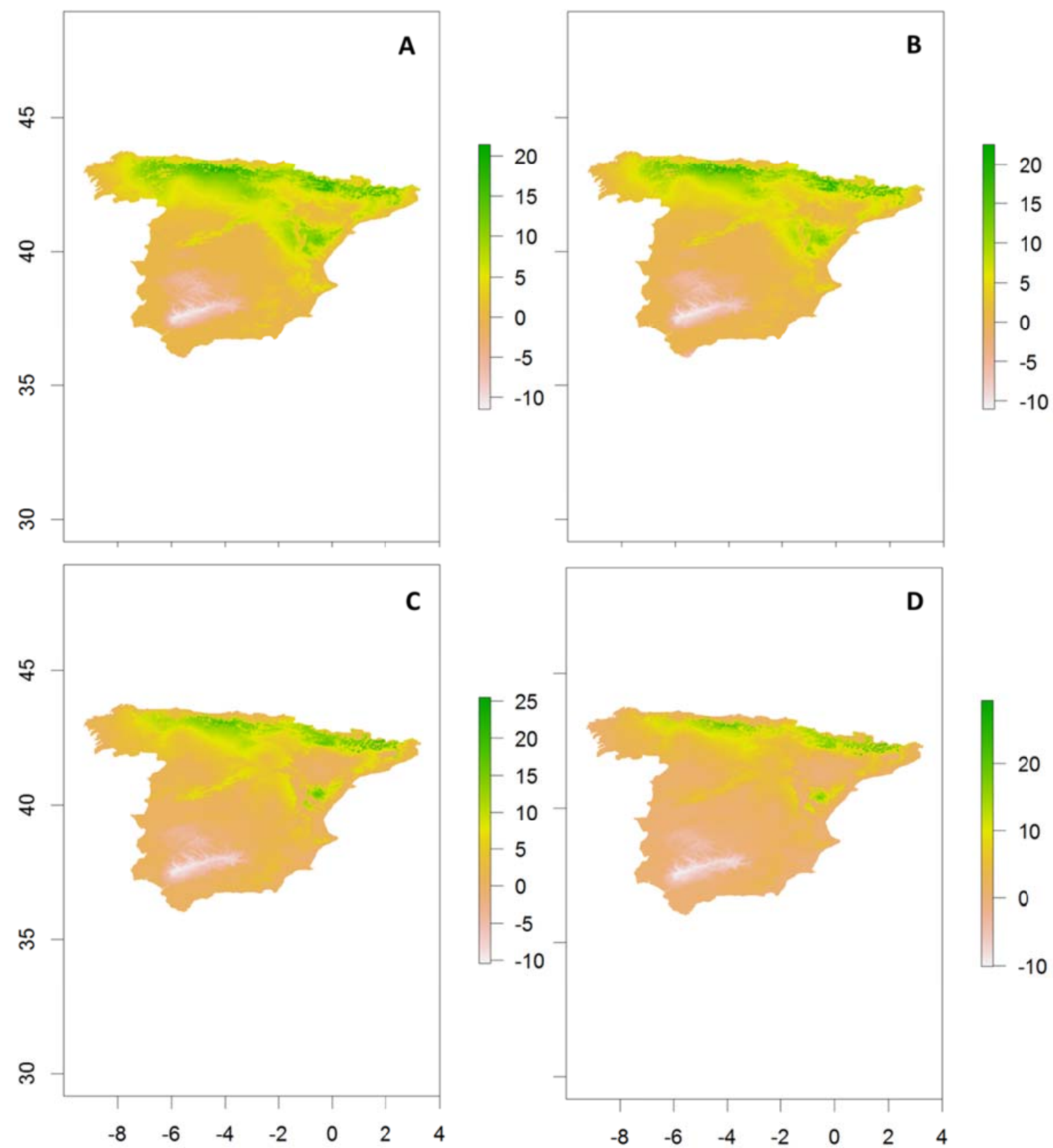

Fig. C1. Multivariate similarity surface (MESS) for Alnus glutinosa (A, C) and Corylus avellana (B, D) comparing current calibration range for each species and mid-Holocene climate conditions under CCSM (A, B) and MIROC (C, D) General Circulation Model. Negative values (white areas) indicate novel climate, which mean values in the mid-Holocene outside the current calibration range. Positive values indicate that mid-Holocene conditions are similar to the values found in the calibration range. 
Appendix D. Non-metric multidimensional scaling (NMDS) for presence datasets.
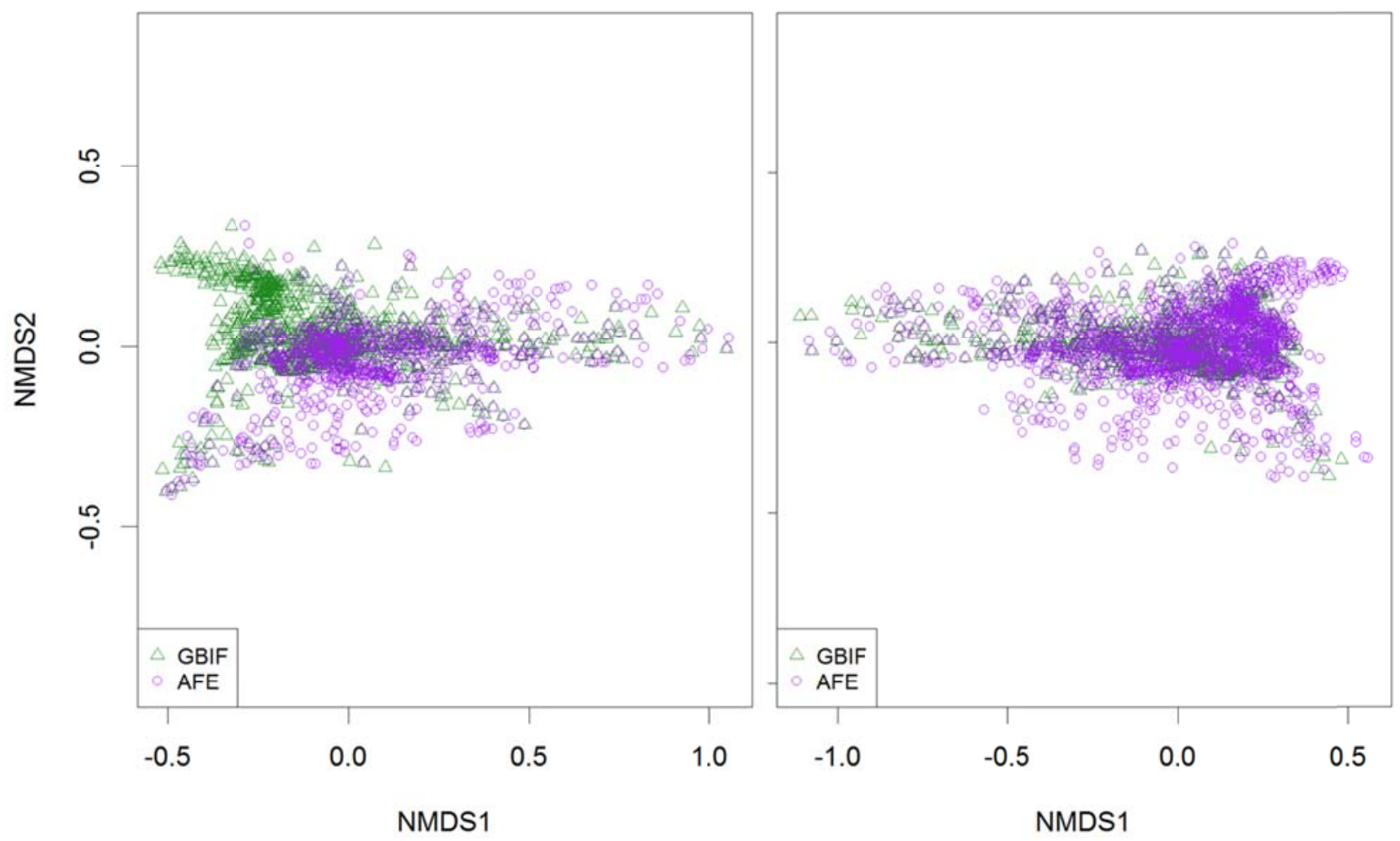

Fig. D1. Non-metric multidimensional scaling (NMDS) for GBIF (green triangles) and Atlas Florae Europaeae (purple diamo nds) datasets for Alnus glutinosa (A) and Corylus avellana (B) at 50km. WORLDCLIM variables used in the NMDS: BIO 01 $, 05,06,12,13,14,16$ and 17. Stress value $=0.051$ for Alnus glutinosa and 0.0558 for Corylus avellana. The geographic bia $\mathrm{s}$ in GBIF (Beck et al., 2014) is not resulting in an environmental bias because there is an overlap in the environmental space between the GBIF data and the AFE data for both species. 


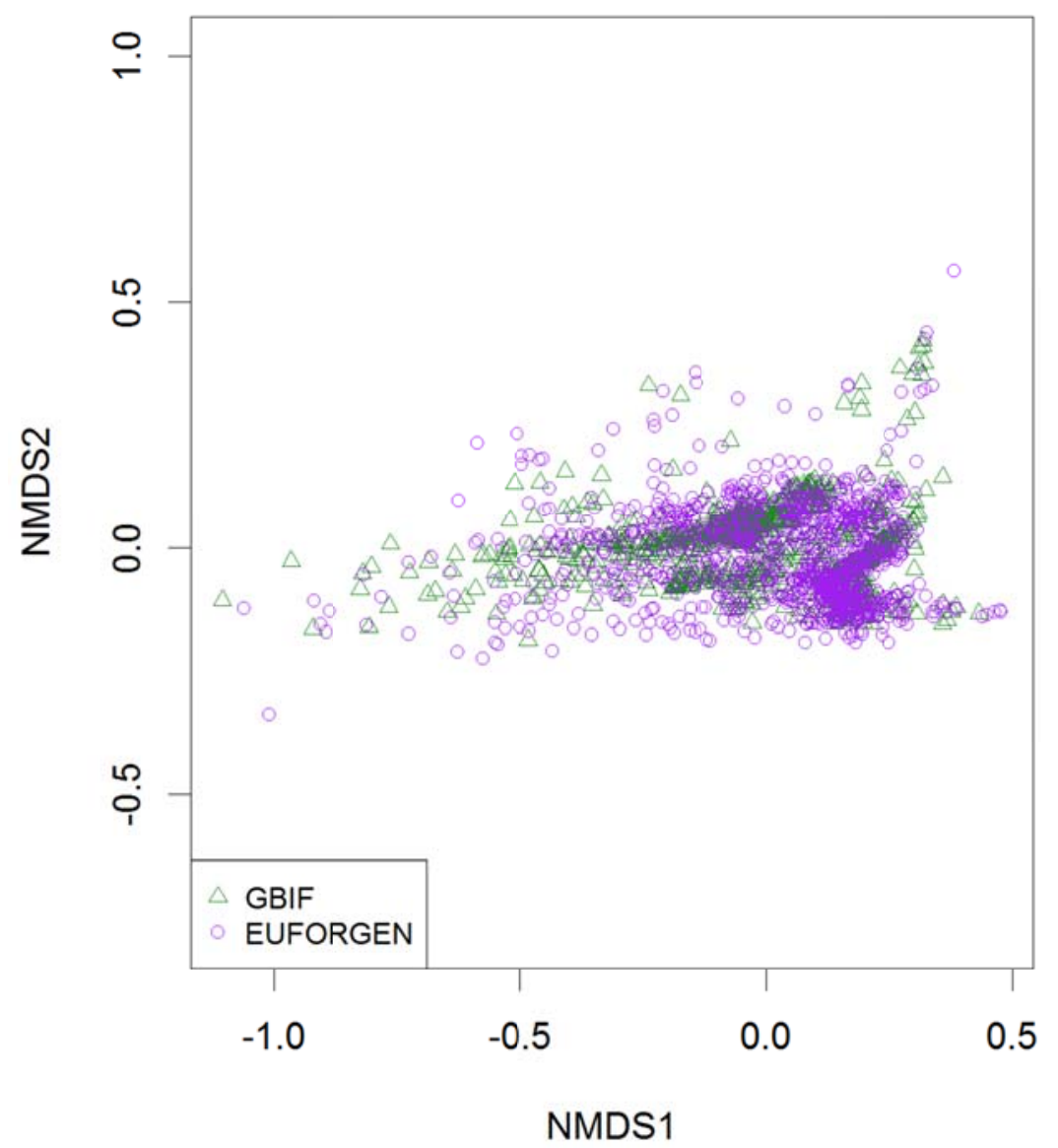

Fig. D2. Non-metric multidimensional scaling (NMDS) for GBIF (green triangles) and Euforgen (purple diamonds) datasets for Alnus glutinosa at 1km. WORLDCLIM variables used in the NMDS: BIO 01, 05, 06, 12, 13, 14, 16 and 17 (Stress value= 0.058). The two databases (GBIF and EUFORGEN) overlap in the climatic space so our study region and the climate space is well represented in the calibration dataset. 
Appendix E. Past AUC values under CCSM General Circulation Model.

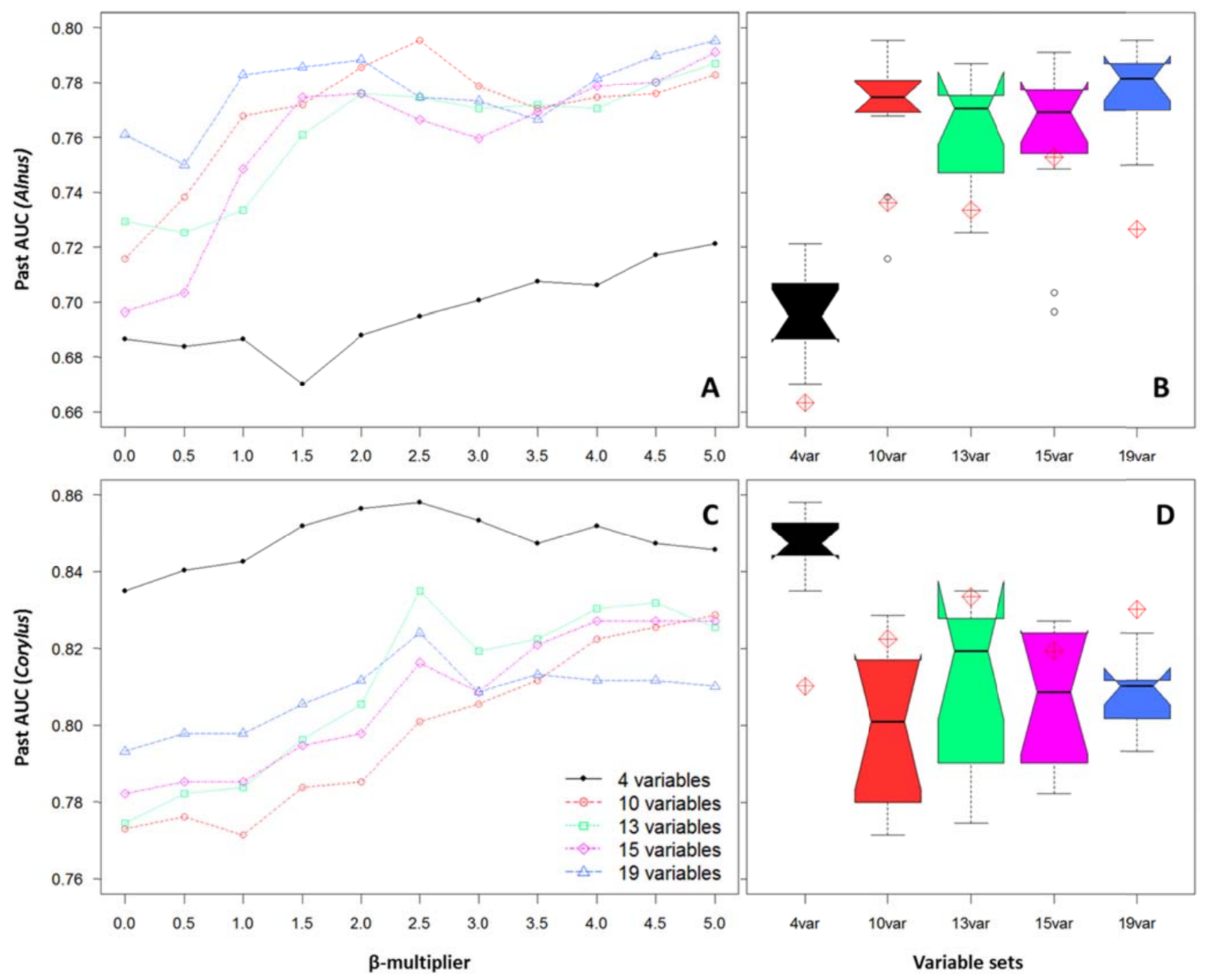

Fig. E1. AUC values for Maxent models projected to the mid-Holocene under CCSM General Circulation Model for Alnus (A and B) and Corylus (C and D) compared to $\beta$-multiplier (A and C) and nested sets of variables (B and D). When only linear, product and quadratic features are included in the models (autofeatures option is deselected) AUC values remained constant, therefore are plotted as points (red crosses) in B and D. Empty circles indicate outliers. 
Appendix F. Correlations values (fossil pollen and past predicted suitability).
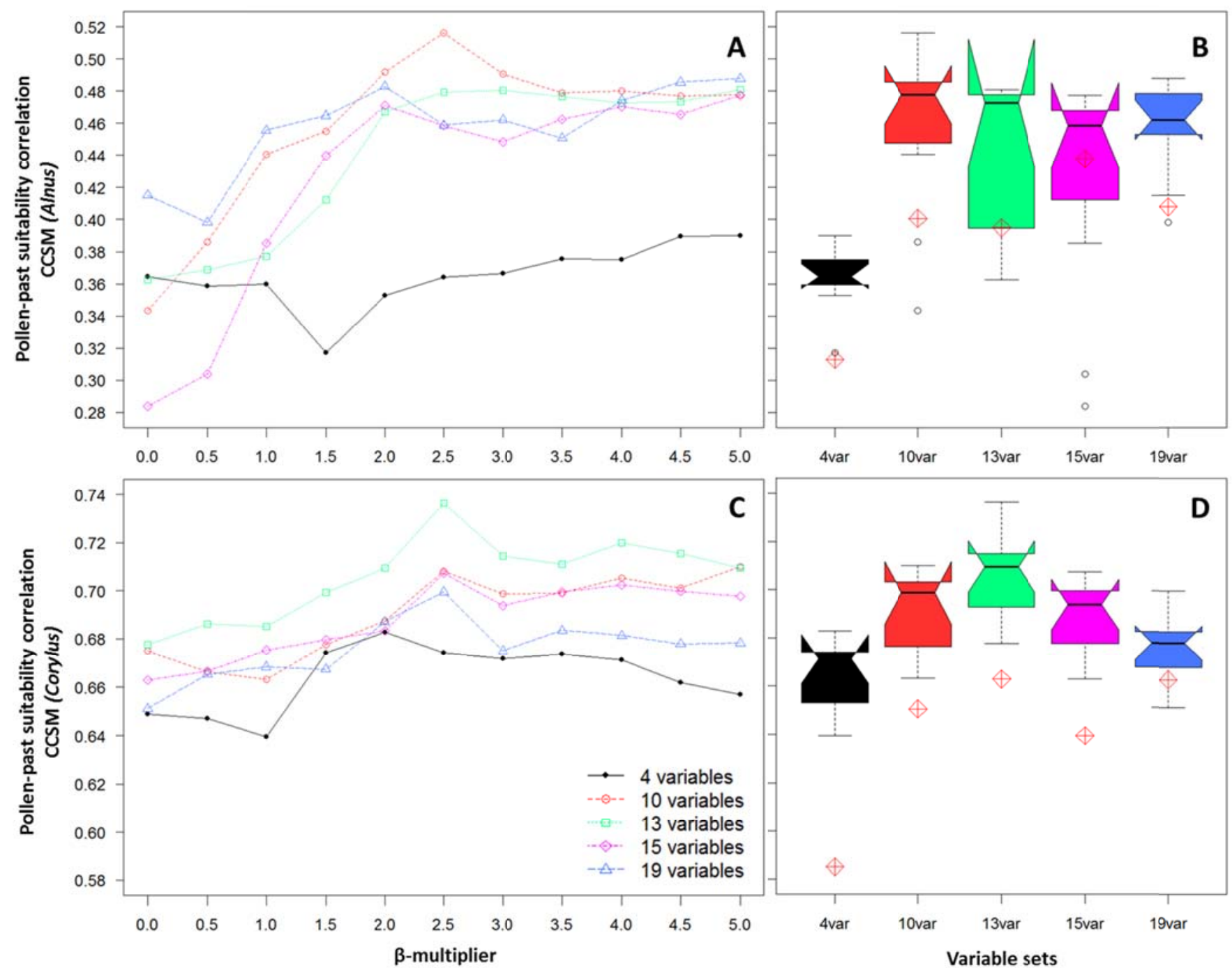

Fig. F1. Correlations values (Spearman coefficient) between fossil pollen percentage and the suitability predicted by the models under CCSM General Circulation Model for Alnus (A and B) and Corylus (C and D) compared to $\beta$-multiplier (A and C) and nested sets of variables (B and D). When only linear, product and quadratic features are included in the model (autofeatures option is deselected) correlation values remained constant, therefore are plotted as points (red crosses) in B and D. Empty circles indicate outliers. 

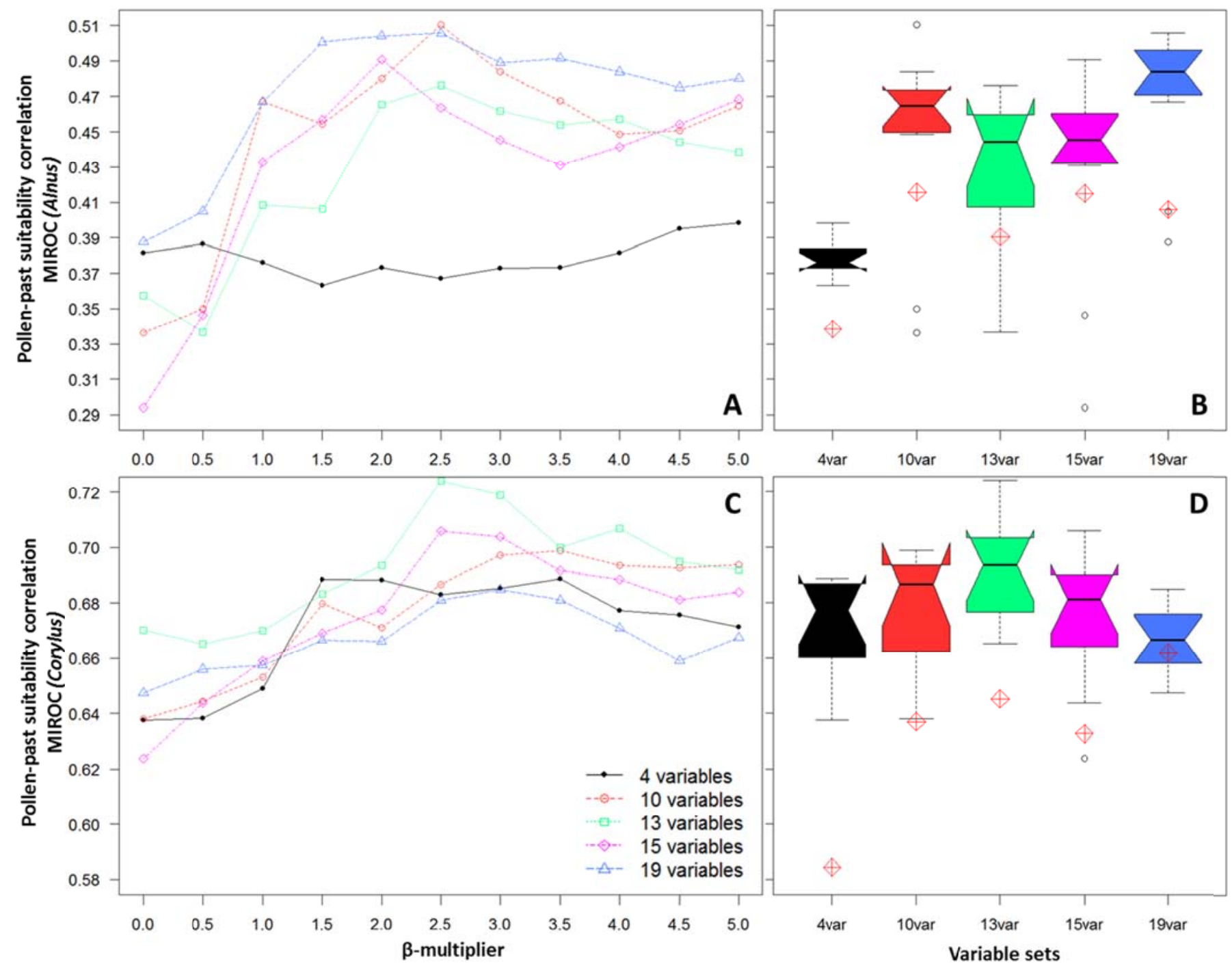

Fig. F2. Correlations values (Spearman coefficient) between fossil pollen percentage and the suitability predicted by the models under MIROC General Circulation Model for Alnus (A and B) and Corylus (C and D) compared to $\beta$-multiplier (A and $\mathrm{C}$ ) and nested sets of variables (B and D). When only linear, product and quadratic features are included in the model (autofeatures option is deselected) correlation values remained constant, therefore are plotted as points (red crosses) in B and D. Empty circles indicate outliers. 
Appendix G. Current Maxent potential distributions for the best model according to AUC and AICc.
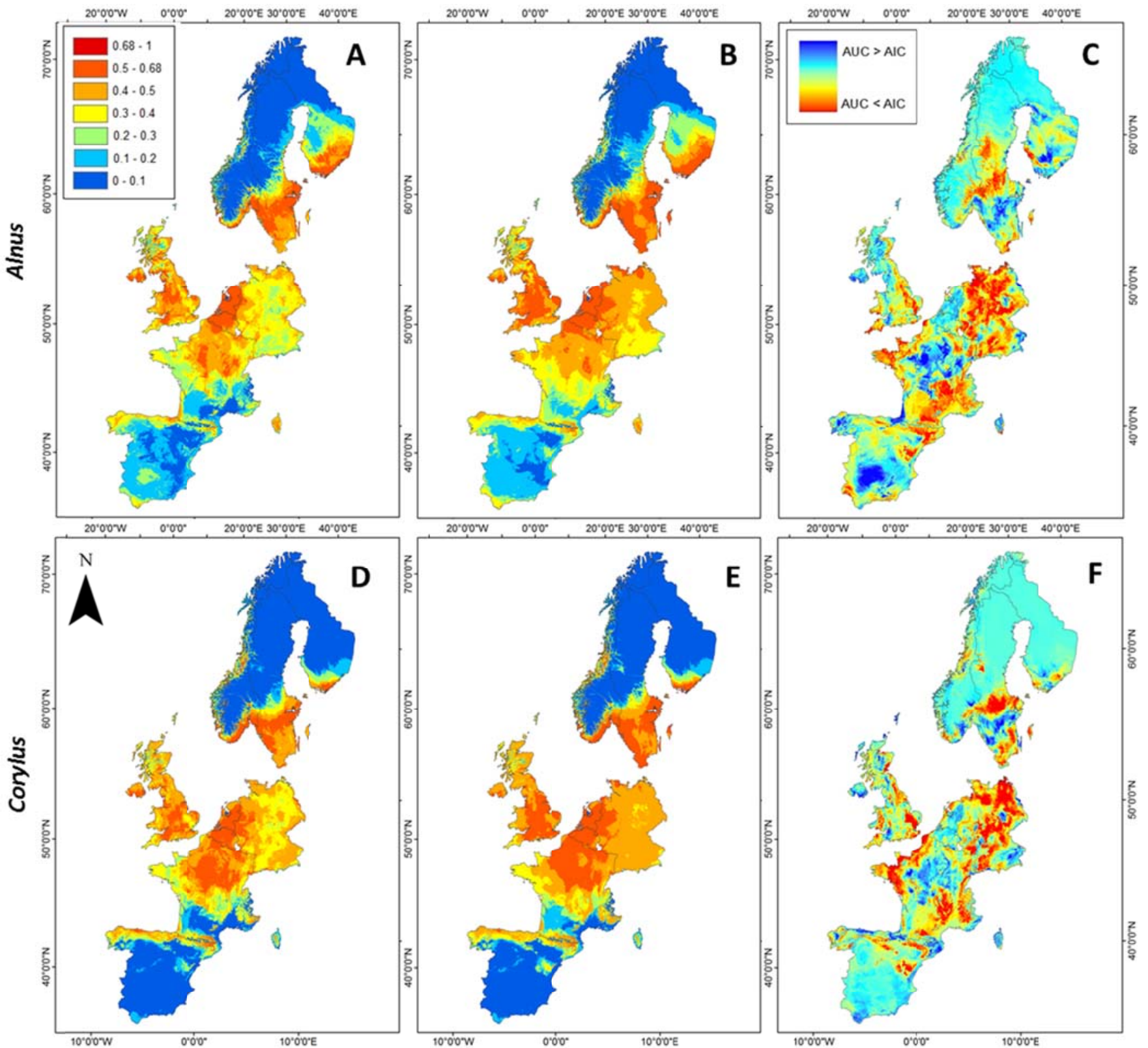

Best model according to AUC

Best model according to AICC

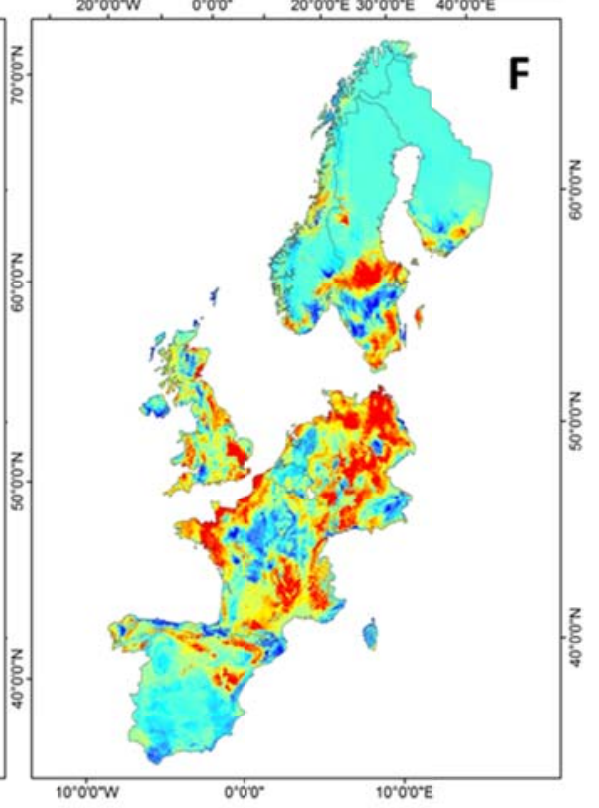

Differences between model predictions (AUC-AICC)

Fig. G1. Current Maxent potential distributions for the best model according to AUC (A and D) and the best model according to AICc (B and E) for Alnus (A and B) and Corylus (D and E). The predicted suitability of the species in the area is displayed in a color gradient: red indicates high suitability and blue indicates low suitability. Differences between them (AUC-selected model minus AICc-selected model) for both species (C and F). The differences in predicted suitabillity are displayed in a color gradient: blue color indicates that AUC-selected model have higher suitability than AICc-selected model and red color indicates that the predicted suitability of AICc-selected model was higher than AUC-selected model. 

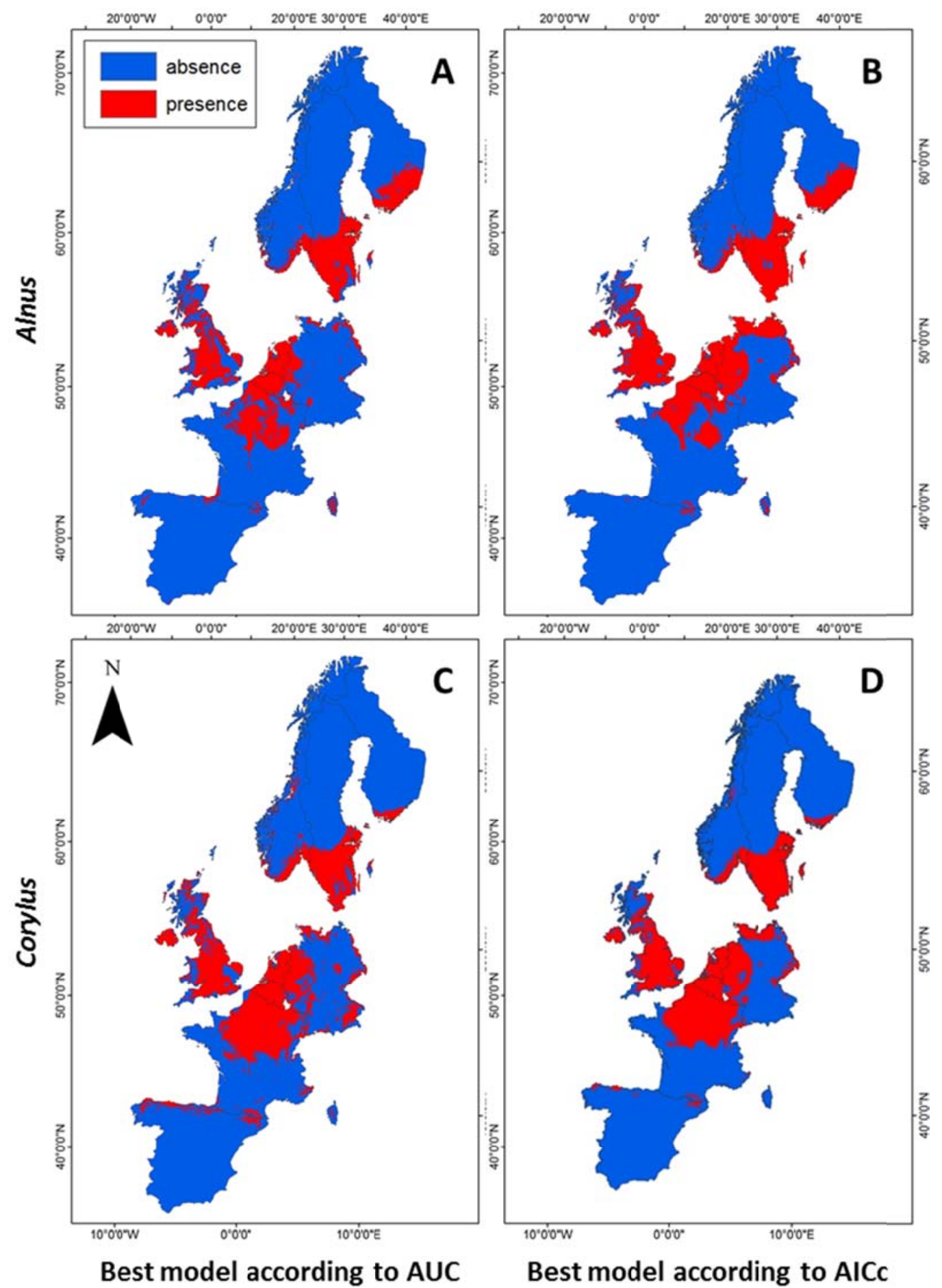

Fig. G2. Current Maxent potential distributions converted to presence/absence using the maximum training sensitivity plus specificity threshold according to the best model selected by AUC (A and D) and the best model selected by AICc (B and E) for Alnus (A, B) and Corylus (D, E). Red color indicates predicted presence and blue indicates predicted absence for the species. 


\section{INFLUENCIA DE LAS POBLACIONES MARGINALES Y DEL USO DE DISTINTAS BASES DE DATOS CLIMÁTICAS EN EL PROCESO DE MODELIZACIÓN, EN LA TRANSFERIBILIDAD ESPACIAL Y EN LAS PREDICCIONES FUTURAS DE LOS MODELOS EN EL ESTUDIO DEL IMPACTO DEL CAMBIO CLIMÁTICO}

Este apartado reproduce el manuscrito:

Moreno-Amat, E., et al. (in prep). Modelling marginal populations of unbalanced presence data species. Improvement the estimations of climate change impacts in the Iberian mountain pine Pinus uncinata.

\subsection{RESUMEN}

La evaluación de los efectos del cambio climático en la distribución de especies es esencial para la toma de decisiones en la conservación y gestión de los espacios naturales. Sin embargo, las predicciones de los modelos pueden verse afectadas por diferentes decisiones del proceso de modelización que pueden conducir a grandes diferencias en los resultados. Entre otros factores, los datos de entrada (presencias y clima) son responsables de una alta variación en la capacidad predictiva y la idoneidad predicha por el modelo. La proporción de hábitat incluida en el modelo afecta de forma importante a las predicciones localizadas en el margen de la distribución de las especies, especialmente si existe un gran desequilibrio entre las poblaciones marginales y centrales de una especie. En este estudio se evalúa el efecto de realizar los modelos con diferentes sub-hábitats de la especie en la capacidad de los modelos de Maxent para predecir la distribución de la especie en sus poblaciones marginales en el presente y en las diferencias que este enfoque proporciona al evaluar los impactos del cambio climático. Para ello, realizamos modelos para Pinus uncinata en la Península Ibérica incluyendo: i) con las presencias incluidas en los diferentes sub-hábitats de la especie, ii) diferentes niveles de complejidad y iii) dos bases de datos climáticas y evaluamos su capacidad predictiva al predecir las poblaciones marginales en el presente y futuro bajo varios escenarios de cambio climático. Este estudio muestra que sólo los modelos de P. uncinata realizados en la actualidad con los datos de presencia asociados a los valores ambientales más extremos predicen cierta idoneidad en las poblaciones marginales. Este estudio proporciona un rango de respuestas para una especie frente al cambio climático que permite un estudio más amplio de la vulnerabilidad de la especie en el futuro. 
Palabras clave: Pinus uncinata, sobreajuste, Maxent, espacio ambiental, espacio geográfico, modelos de distribución de especies, RCP, cambio climático, poblaciones marginales, deuda de extinción, sub-hábitat, base de datos climática.

\subsection{ABSTRACT}

Evaluating the effects of climate change in species distribution is essential for taking decisions in landscape conservation and management. However these predictions can be affected by several modelling choices that might lead to high differences in the results. Among other factors, the input data (presences and climate) remain responsible of a high variability in the model predictive ability and predicted suitability. The proportion of habitat included in the model affects largely in the predictions located at the edge of species, especially if there is an important unbalance between marginal and core populations of a species. In this study we evaluate the effect of modelling different sub-habitats of the species on the ability of Maxent models to predict the distribution of the species in its marginal range in the present and the differences that this approach has when assessing the impacts of climate change. To do so, we run several models for Pinus uncinata in the Iberian Peninsula including: i) different sub-habitats of the species (with the matching occurrences), ii) different levels of complexity and iii) two climatic databases and evaluate their performance when predicting marginal populations in the present and into the future under several climate change scenarios. This analysis shows that only the $P$. uncinata distribution models performed with the presence data associated to the most extreme environmental values predict some suitability in the marginal populations in the present. This study provides a range of responses for a species when facing climate change that allows a more comprehensive study of species future vulnerability.

Keywords: Pinus uncinata, overfitting, Maxent, environmental distribution, geographical distribution, species distribution models, RCP, climate change, marginal populations, extinction debt, sub-habitat, climate database.

\subsection{INTRODUCTION}

Disentangling the role of climate on vegetation distribution is a fundamental issue in ecology that helps us understanding the response of species to the new climatic conditions (Araújo and Pearson, 2005, IPCC, 2007 and Gaston et al., 2003). Specially, ecological studies in mountainous areas are of special interest as they host many species at their ecological or geographical boundaries or relict populations of former wider distributed species that are 
particularly vulnerable to the impacts of climate change due to their very specific characteristics (Valladares et al., 2005 and Rubiales et al., 2010). Such edge or marginal populations could be at their potential optimum (in equilibrium with the climate) or in extinction debt, where the environmental conditions are not favorable for the population but it will take some time until the population becomes extinct (Hanski and Ovaskainen, 2002 and Kuussaari et al., 2009).

The Iberian Peninsula hosts many tree species that often reach their distribution limits, as the case of Pinus uncinata Ramond ex DC. in Lam. \& DC. This pine is a microtherm alpine species that requires the highest precipitation regime of all the Iberian pines although it can resist large physiological droughts in the winter months (Ruiz de la Torre, 2006). Although this long-lived species has resisted large variations in environmental conditions, such as those occurred during the late Quaternary, it has to cope with warmer conditions since the Lateglacial which reduce the available space for micotherm species to higher elevations and therefore might result in the disappearance of these populations (Rubiales et al., 2010).

Some previous predictions based on species distribution model in this species showed that future climate change will intensely affect the distribution of this species (Felicísimo et al., 2011), inducing its upper elevation migration to higher areas that might not be able for colonization (Benito-Garzón et al., 2008). The Pinus uncinata populations in Vinuesa and Gúdar (Fig.4.1) constitute the western and southern limits of the global natural range of the species. These rear-edge populations show a genetic distinctiveness that might be resulted from long spatial isolation (Dzialuk et al., 2009 and Heuertz et al., 2010) which eventual predicted disappearance will constitute an important decrease of the diversity and local adaptive potential of the species (Hampe and Petit, 2005). Assessing the impact of the predicted climate change in these isolated populations becomes critical to urge adaptive management decisions to prevent such diversity loss.

Species distribution models (SDMs) are commonly used numerical tools that relate species presences/absences and environmental conditions to estimate the ecological niche or to predict the distribution of a species in space and time (Elith and Leathwick, 2009). SDMs have been largely used in conservation studies (Araújo et al., 2011), invasive species research (Gallien et al., 2012), to evaluate the stability of species niche (Peterson et al., 1999), to inform management strategies (Sinclair et al., 2010) and in climate change studies (Thuiller et al., 2005 and Kearney et al., 2010). 
SDMs have been applied to a great extent to study the effect of past or future environmental conditions in the species distribution because their ability of predicting species response in time. In some cases the temporal transferability of the models can be validated with independent data such as in past times with paleobotanical data (Moreno-Amat et al., 2015) but the reliability of future projections cannot be tested. A wide variety of algorithms have been used for SDMs (see reviews by Elith and Leathwick, 2009 and Guisan and Zimmermann, 2000). SDMs performance and output have proven to be affected by several modelling decisions (Buisson et al., 2010 and Dormann et al., 2008). Firstly, the input data, the extent used in the study (Mateo et al., 2010, Phillips et al., 2009 and Varela et al., 2014), the selection of environmental predictors (Harris et al., 2013 and Synes and Osborne, 2011) and model complexity (Moreno-Amat et al., 2015 and Warren and Seifert, 2011) have great influence in the model results. Finally, general circulation model, climate scenarios and modelling algorithm contributes greatly to variation in projections (Buisson et al., 2010). Therefore assessing the spatial transferability of SDMs into future climate change is critical.

SDMs effectively predict species potential distribution even with low sample sizes (Hernandez et al., 2006 and Shcheglovitova and Anderson, 2013) and biased or incomplete species data (Newbold, 2010). Even though SDM are generally developed for the whole range of a species (e.g. Benito-Garzón et al., 2008), some studies have demonstrated that the intraspecific variability of a species highly influence species distributions under climate change (Benito-Garzón et al., 2011 and Valladares et al., 2014). Several authors have assessed the effect of marginal populations on SDMs results (e.g. Fernández et al., 2015, Soley-Guardia et al., 2016, Vale et al., 2014 and Williams-Tripp et al., 2012), demonstrating that different results are obtained when modelling populations entities versus the entire species range thus proving that species respond differently to climate change across their range. Moreover the usual SDMs modelling approach (using the entire species presences) have been proved to underestimate the marginal populations' current suitability (Fernández et al., 2015). Nonetheless, the SDMs predictions of the species' rear-edge with very few presences in comparison to core populations in SDMs remains poorly studied.

In this study, we deepen the SDMs predictions of the highly unbalance Iberian marginal populations to improve vulnerability studies of such populations facing climate change. For that purpose, we examine how varying the habitat definitions of Pinus uncinata (by varying the occurrence dataset associated) varies the Maxent current and future predictions in the marginal populations. 


\subsection{MATERIALS AND METHODS}

\subsubsection{Species data and study area}

Pinus uncinata (montain pine) is an European tree species which natural range includes the Center and West of Alps, the Pyrenees and the Iberian mountain range (Castroviejo et al., 1986-2016 and Tutin et al., 1964) (Fig. 4.1A-S4.1). It is a soil indifferent species that inhabits slopes, rocky deposits, wet soils and bogs at altitudes from (800) 1400 to 2700 m.a.s.l. representing the upper limit of the tree-line vegetation in the Iberian Peninsula (Costa et al., 1997 and Do Amaral Franco, 1986). At high elevations P. uncinata is replaced by subalpine shrubs and grassland and at lower altitudes by Pinus sylvestris L., Abies alba, Fagus sylvatica in the Iberian Peninsula and contacts with Larix decidua or Pinus cembra in the Alps.

The taxonomy of this species has been under discussion considering it either a subspecies of Pinus mugo or a separate species (Christensen, 1987 and Businsky, 1999) due to the high morphological variability regarding growth habit, cone and needle characters (Heuertz et al., 2010). Hybridization of $P$. uncinata and P. sylvestris (Pinus $x$ rhaetica Brügger) is frequently found in their contacting populations as in the Iberian mountain range (Rubiales et al., 2010).
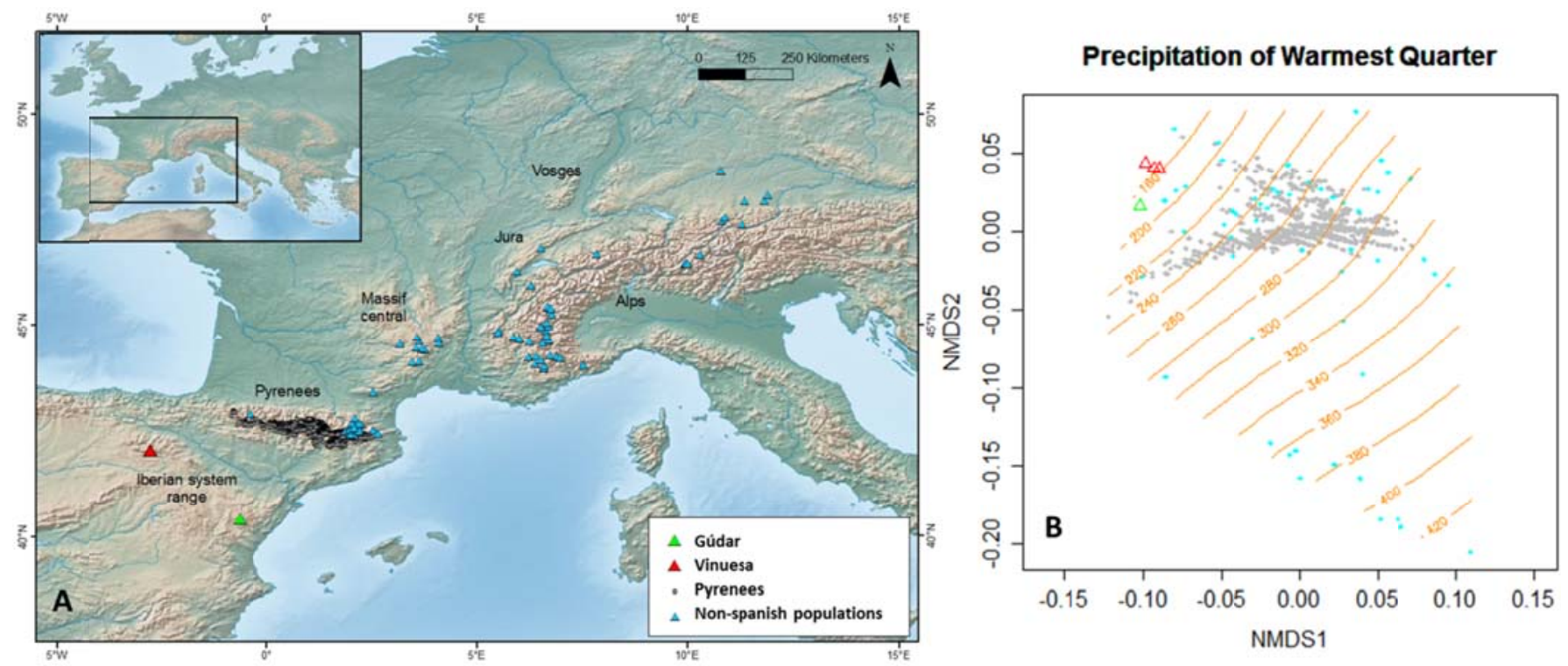

Fig. 4.1 A) Current Pinus uncinata distribution in Europe from the IFN3 (2008) and IGN (2013) and B) non-metric multidimensional scaling (NMDS) of the Pinus uncinata presences in A) with WORLDCLIM database. The orange lines represent the precipitation of the warmest quarter (Bio 18) gradient in $\mathrm{mm}$.

Current occurrence data for the species (Fig. S4.1) were obtained from the following datasets to fully incorporate the environmental range of the species in the analysis in order to avoid extrapolation in future projections (Hijmans and Elith, 2013): Spanish forest inventory (IFN3, 2008), French forest inventory (IGN, 2013), Atlas Florae Europaeae (Jalas and 
Suominen, 1972-1994), Atlas of the World's Conifers (Farjon and Filer, 2013), Geographic distribution of the pines of the world (Critchfield and Little, 1966) and the Global Biodiversity Information Facility database (GBIF; http://www.gbif.org/). After a quality analysis in the differences among these datasets regarding data accuracy, species identification (taxonomy), geographic resolution, sampling effort, and the exclusion of nonnatural areas, a non-metric multidimensional scaling (NMDS) analysis was conducted on the databases to see how similar these presences were in the environmental space. Since the Spanish presences were obtained from the high quality Spanish forest inventory at $1 \mathrm{~km}$ resolution and they contained the environmental information of the southern part of the species native range (Fig 1B) which hosts the necessary information to project to future warmer climates, we focused on the populations of Iberian Peninsula as a case of study.

From the $1259 P$. uncinata presences obtained from the Spanish forest inventory, 1121 natural occurrences were selected to generate the models after removing the plots outside the natural provenances (Ceballos, 1966 and Martín et al., 1998).

\subsubsection{Environmental variables}

In this study, two climatic datasets were used for both present and future period. First, as numerous climate change SDMs-studies, we used WORLDCLIM database, obtained from monthly temperature and precipitation data for the years 1950-2000 at 30 arc-second $(\sim 1$ $\mathrm{km} 2$ ) resolution, which is freely available covering the entire world (http://www.worldclim.org/; Hijmans et al., 2005). This database supplies 19 bioclimatic variables including annual trends, seasonality and extremes in climate that represent environmental limits for the organisms (Hijmans et al., 2005). The second climatic database consisted in observed temperature and precipitation data from the meteorological stations network of the Spanish National Meteorology Agency (AEMET; series 1951-2006). This database is only available for Spain but it has 1830 temperature stations and 5053 precipitation stations whilst in continental Spain WORLDCLIM uses 142 weather stations for mainland Spain (Fig. 4.2). These data were interpolated to a grid with $1 \mathrm{~km}$ resolution for continental Spain following Thin Plate Splines interpolation methodology (Hutchinson, 1991), the same interpolation method that uses WORLDCLIM, and using altitude as covariate for both temperature and precipitation. Finally the 19 bioclimatic variables for the present time were obtained through the "dismo" R package (Hijmans et al., 2015). 

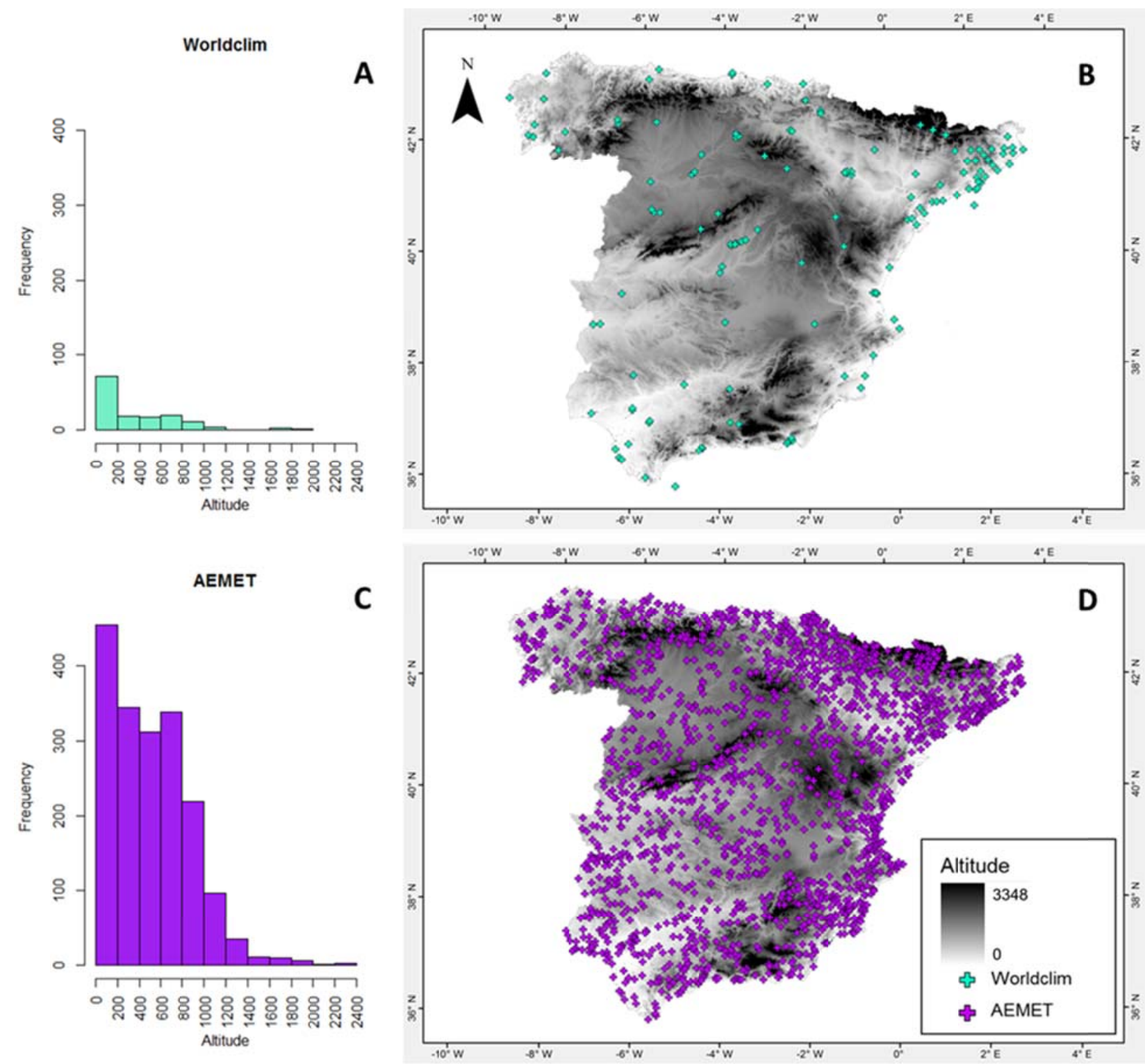

Fig. 4.2. Weather stations used to generate the two climate datasets. Green A) and B): WORLDCLIM dataset (http://www.worldclim.org). Purple C) and D): AEMET dataset. A) and C): Altitude distribution of the weather stations. B) and D): Geographic distribution of the weather stations in the study area (continental Spain).

To simulate future climatic conditions in the study area we used seven of the most recent Climate Models (Table S4.1) that have been used in the Fifth Assessment report of the Intergovernmental Panel on Climate Change (IPCC, 2014). As future scenarios we used two Representative Concentration Pathways (RCPs) (Taylor et al., 2009), RCP4.5 (a medium mitigation scenario) and RCP8.5 (a high emissions scenario), and we studied our simulations for two temporal periods (2041-2060 and 2061-2080).

As with the current climate, we obtained future climate for Spain from the WORLDCLIM database downscaled to $1 \mathrm{~km}$ as described in Hijmans et al., (2005) and calculated the future bioclimatic variables with the median of the seven climatic models (Table S4.1). 
A two-step analogue statistical method developed by Ribalaygua et al. (2013) was used for downscaling the daily climatic data of the maximum and minimum temperatures and the precipitation from AEMET, for each station and day. The first step of the methodology, common to temperature and precipitation, is an analogue stratification (Zorita and Von Storch, 1999) in which the $n$ days most similar to the problem day to be downscaled are selected. In a second step, the temperature is obtained using a multiple linear regression analysis using the selected $n$ most analogous days. The second step for precipitation works in a different way, by using an empirical distribution function. Further details of the methodology can be found in Ribalaygua et al. (2013). As a systematic error is obtained when comparing the simulated data from climate models with the observed data, which is associated to every downscaling methodology and to every climate model (which usually introduce a bias over the data), we corrected this systematic error by using a parametric quantile-quantile method (Monjo et al., 2014) on the future climate simulations. The variables were extracted at the original resolution (around $2^{\circ}$ cell sizes; Table S1) and the data was interpolated to a grid with 30 arc second $\left(\sim 1 \mathrm{~km}^{2}\right)$ with the Thin Plate Splines method. Finally we obtained the median of the downscaled future monthly temperatures and precipitations of the seven climatic models (Table S4.1) and the 19 bioclimatic variables were calculated. The downscaled present and future scenarios for the Iberian Peninsula for the AEMET meteorological dataset were conducted by Foundation for Research on Climate (FIC) through the research project ("Scientific research for the adaptation of Pinus pinaster Ait. and Pinus halepensis Mill. to climate change").

Also four topographic variables (topographic diversity, altitudinal range index, slope and wetness index) were derived for the Iberian Peninsula from the Shuttle Radar Topographic Mission elevation model (USGS, 2004) at 3 arc second $(\sim 90 \mathrm{~m})$ resolution in the GRASS GIS environment (GRASS Development Team, 2012) and aggregated to a $1 \mathrm{~km}$ resolution. These variables were included to characterize the topographical complexity of the area following Benito et al., (2011 and 2016).

From the 23 environmental variables, the 7 final variables (Bio 3-isothermality, Bio 5maximum temperature of warmest month, Bio6- minimum temperature of coldest month, Bio12- annual precipitation, Bio18-precipitation of warmest quarter, wetness index and topographic diversity) were obtained (Table S4.2) through a selection process based on ecological criteria (Prentice et al., 1992 and Pearman et al., 2008), correlation (Pearson $\mathrm{r} \leq$ 
0.75 ) and collinearity [variance inflation factor $<5$; through the "HH" R package (Heiberger, 2015)] for the WORLDCLIM and the AEMET climate database.

\subsubsection{Habitat definition}

After an univariate analysis on each environmental variables associated to the $P$. uncinata dataset (e.g. see Gaines and Denny, 1993 and Blanco et al., 2000), five types of habitats were defined (hereafter called sub-habitats) as follows: i) the optimal or central sub-habitat of the species includes the $80 \%$ of the environmental range of the species (i.e. from $10^{\text {th }}$ to $90^{\text {th }}$ percentile), ii) the suboptimal sub-habitat includes the $90 \%$ (i.e. from $5^{\text {th }}$ to $95^{\text {th }}$ percentile) of the environmental range of the species, iii) the subtotal sub-habitat includes the $99 \%$ (i.e. from $0.5^{\text {th }}$ to $99.5^{\text {th }}$ percentile), and iv) the total sub-habitat which includes the $100 \%$ of the species presences. Finally the marginal or edge sub-habitat in this study is defined as the habitat between both extreme values of the variable and the limits of the subtotal (Min- $0.5^{\text {th }}$ percentile and $99.5^{\text {th }}$ percentile-Max range) which constitutes the $1 \%$ of the environmental range of the species habitat.

\subsubsection{Model calibration}

Current distribution models for P. uncinata were generated with the Maxent modelling algorithm version 3.3.3k (Phillips et al., 2006) through the "ENMeval" R package (Muscarella et al., 2014). One set of occurrence data for each habitat were used to calibrate the models in the present (Table 4.1). These sets of occurrences were selected by overlapping the presences with each habitat category (environmental range) defined by the intersection of the 7 selected variables in each climatic dataset as detailed in the definition of sub-habitats section. Consequently, the occurrences included in each habitat category differed among the climatic datasets (Table 4.1).

We randomly selected 10,000 background points in Spain to represent the distribution of environmental conditions available at the study region (Phillips and Dudík, 2008). The background data was the same in all the models to prevent potential sources of variation resulting from differences in the background. 
Table 4.1. $P$. uncinata occurrences classified into habitat categories used in the models and the percentage of environmental range that they represent in each climatic database.

\begin{tabular}{|c|c|c|}
\hline Sub-habitat & $\begin{array}{c}\text { Number of presences } \\
\text { included (WORLDCLIM) }\end{array}$ & $\begin{array}{c}\text { Number of presences } \\
\text { included (AEMET) }\end{array}$ \\
\hline Marginal & 44 & 49 \\
\hline Optimal & 496 & 245 \\
\hline Suboptimal & 731 & 430 \\
\hline Subtotal & 1077 & 736 \\
\hline Total & 1121 & 1121 \\
\hline
\end{tabular}

We generated 66 models for each sub-habitat and climatic dataset by using $\beta$-multiplier values ranging from 0 to 5 (in steps of 0.5 ) and different feature classes combinations (L, LQ, $\mathrm{H}, \mathrm{LQH}, \mathrm{LQHP}, \mathrm{LQHPT}$; being $\mathrm{L}=$ linear, $\mathrm{Q}=$ quadratic, $\mathrm{P}=$ product, $\mathrm{H}=$ hinge, and $\mathrm{T}=$ threshold) (Phillips and Dudík, 2008).

We divided the dataset in calibrating and testing bins dividing the occurrence data with the block method (Muscarella et al., 2014) which prevents spatial autocorrelation between testing and training localities and it is recommended for studies related to temporal/spatial transferability or facing non-analog conditions as may be the case in climate change studies. This method divides the occurrence data into four bins of the same size (as far as possible) following the latitude and longitude lines that separate dataset localities. Once the dataset (both presence and background) is divided into one of the four bins, the ENMevaluate function builds four models for each combination of settings, using three bins for model training and the remaining for testing (Muscarella et al., 2014).

\subsubsection{Model evaluation}

The performance of the models under current conditions was assessed using the testing bin of the partitioning block method data included in the "ENMeval" R package (Muscarella et al., 2014) and different evaluation statistics were obtained for each of the four models, and also a full model using the unpartitioned dataset (Muscarella et al., 2014).

We calculated the AUC (Area Under the receiver operating characteristic Curve) which is the most frequent statistic to evaluate the predictive accuracy of SDMs (Lobo et al., 2008). The AUC reports the discrimination power of the model when classifying presences and absences from the study area (Fielding and Bell, 1997). The AUC evaluation was based on $\mathrm{AUC}_{\mathrm{TEST}}$ and $\mathrm{AUC}_{\mathrm{DIFF}}$, being $\mathrm{AUC}_{\mathrm{TEST}}$ the mean $\mathrm{AUC}$ value of the four iterations based on 
the ability to predict the testing presences, and $\mathrm{AUC}_{\mathrm{DIFF}}$ the mean value between $\mathrm{AUC}_{\mathrm{TRAIN}}-$ $\mathrm{AUC}_{\mathrm{TEST}}$, being $\mathrm{AUC}_{\mathrm{TRAIN}}$ the AUC based on training localities (Muscarella et al., 2014).

Secondly, to select models with optimal complexity we obtained the AICc (Akaike Information Criterion corrected for small sample sizes) which balances the goodness of fit and the number of parameters of the model (Johnson and Omland, 2004; Muscarella et al., 2014): i) calc.aicc is the AICc value for each model run, ii) DAICc is the difference between the AICc of each model and the model with the lowest AICc value, iii) w.AIC is the Akaike weight of the model for model averaging when more than one model is highly supported by the data (i.e. w.AIC of the best model $<0.9$; Johnson and Omland, 2004).

We computed two threshold-dependent metrics to quantify overfitting (Muscarella et al., 2014): i) $\mathrm{OR}_{\mathrm{MTP}}$ which is the proportion of testing presences with suitability values lower than the minimum suitability value of the training presences and ii) $\mathrm{OR}_{10}$ which is the proportion of testing presences with suitability values lower than the value that excludes the 10 percent lowest suitable training presences.

Additionally, to quantify how different the geographic predictions of each one of the 66 models and their corresponding Maxent default settings model are, we obtained the Schoener's D statistic (Schoener, 1968). We computed the niche overlap of each model (for each sub-habitat, climate database, $\beta$-multiplier and feature class) and its corresponding default model (for each sub-habitat, climate database, $\beta$-multiplier=1 and feature class="Autofeatures"). The values of the D statistic vary from zero to one, with values close to one indicating models with higher similarity.

An independent-samples t-test was realized to compare the different evaluation metrics in AICc versus default selected models and in WORLDCLIM versus AEMET climatic datasets. A one-way ANOVA between sub-habitats was conducted to compare the effect of modelling sub-habitats on the different evaluation metrics.

Finally, for each climatic dataset and sub-habitat we selected the Maxent default settings models and the AICc-selected models (DAICc $=0$ and DAICc $<5)$ (Table 4.2). These selected models (Table 4.2) were projected to the study area under three different time periods (current, 2041-2060 and 2061-2080) and two representative concentration pathways (RCP45, $\mathrm{RCP85)}$ to evaluate the differences in the predicted distribution of the species. 


\subsection{RESULTS}

\subsubsection{Habitat and environmental analyses}

The two populations located in the Iberian mountain range (Castillo de Vinuesa in SoriaLa Rioja and Gúdar in Teruel, Fig. 4.1) present more extreme conditions than the Pyrenees (higher maximum temperature of warmest month, lower annual precipitation and lower precipitation of warmest quarter) for both climatic dataset (Table 4.2). The minimum temperature of the coldest month in the Pyrenees was lower than in Vinuesa and Gúdar for AEMET but not in WORLCLIM. The differences between the two climatic datasets were remarkable in the maximum values of the current maximum temperature of AEMET warmest month (AEMET values were $4{ }^{\circ} \mathrm{C}$ higher) and in the annual precipitation (600mm higher) than in the WORLDCLIM database (Table 4.2).

Table. 4.2. Environmental ranges and the median values of the Iberian populations occurrences for both climatic datasets. Units: temperature values in ${ }^{\circ} \mathrm{C}$ and precipitation values in $\mathrm{mm}$.

\begin{tabular}{|c|c|c|c|c|c|c|c|c|c|c|c|}
\hline \multirow[b]{2}{*}{ Variable } & \multirow[b]{2}{*}{ Code } & \multicolumn{5}{|c|}{ WORLDCLIM } & \multicolumn{5}{|c|}{ AEMET } \\
\hline & & Min & Max & Pyrenees & Vinuesa & Gúdar & Min & Max & Pyrenees & Vinuesa & Gúdar \\
\hline Isothermality & bio 3 & 3.1 & 3.8 & 3.3 & 3.8 & 3.5 & 2.930 & 4.240 & 3.717 & 3.615 & 3.526 \\
\hline $\begin{array}{c}\text { Maximum } \\
\text { Temperature } \\
\text { of Warmest } \\
\text { Month }\end{array}$ & bio 5 & 13.5 & 24.6 & 18.4 & 21.4 & 21.1 & 16.300 & 28.2 & 21.4 & 21.800 & 22.4 \\
\hline $\begin{array}{c}\text { Minimum } \\
\text { Temperature } \\
\text { of Coldest } \\
\text { Month } \\
\end{array}$ & bio 6 & -8.7 & 0.9 & -4.6 & -6 & -5.4 & -7.4 & -0.9 & -4.8 & -3.9 & -3.1 \\
\hline $\begin{array}{c}\text { Annual } \\
\text { Precipitation }\end{array}$ & bio_12 & 782 & 1443 & 1166 & 914.333 & 813 & 778.300 & 2036.700 & 1146.600 & 1120.300 & 786 \\
\hline $\begin{array}{c}\text { Precipitation } \\
\text { of Warmest } \\
\text { Quarter }\end{array}$ & bio 18 & 168 & 319 & 270 & 172.333 & 173 & 141.900 & 363.200 & 263 & 144 & 169.900 \\
\hline $\begin{array}{c}\text { topographic } \\
\text { diversity }\end{array}$ & topo_div & 67.397 & 74.674 & 73.550 & 72.741 & 70.086 & 67.628 & 74.432 & 73.531 & 72.597 & 70.338 \\
\hline wetness index & wet index & 5.074 & 9.178 & 5.981 & 5.397 & 5.548 & 5.272 & 8.577 & 5.972 & 5.577 & 5.414 \\
\hline
\end{tabular}

The two populations from the Iberian mountain range are at the limit of the environmental conditions for both the European (Fig. 4.1B) and the Iberian distribution (Fig. 4.3). 


\section{Precipitation of Warmest Quarter}

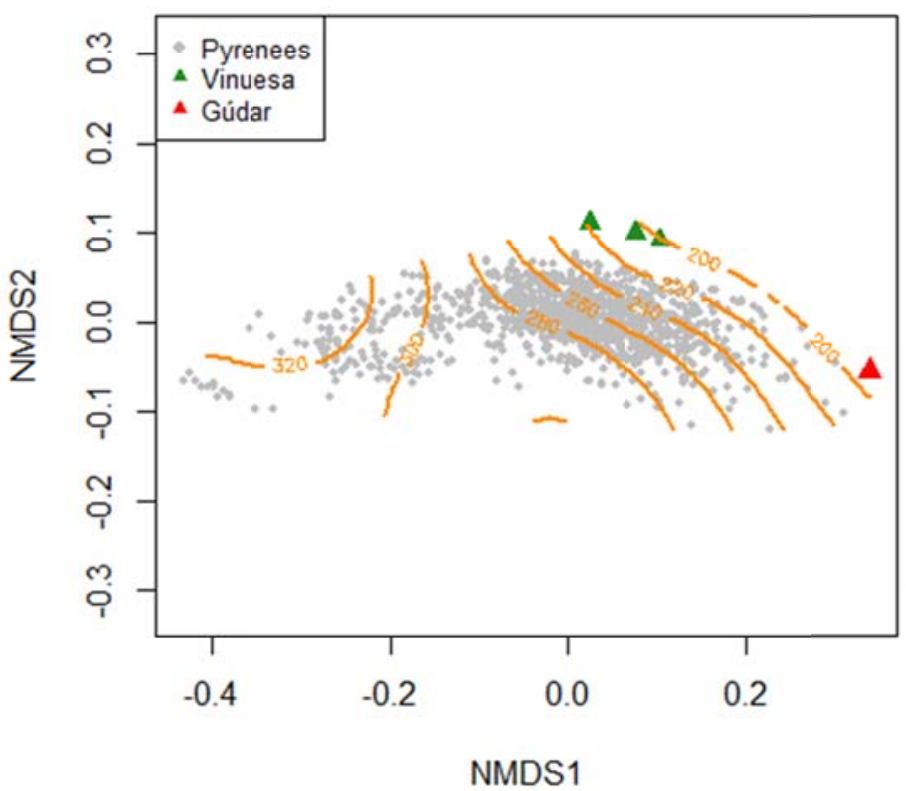

Fig. 4.3. Non-metric multidimensional scaling (NMDS) of the $P$. uncinata current natural presences in the Iberian Peninsula. The orange lines represent the precipitation of the warmest quarter (Bio 18) gradient in $\mathrm{mm}$.

For WORLDCLIM database, the variables with the highest variability were the min temperature of coldest month (Bio6) and max temperature of warmest month (Bio5), whereas for AEMET database were Bio6 and annual precipitation (Bio12). For both climatic datasets, the topographic diversity and the isothermality (Bio3) presented the lowest variability (Fig.

\section{4, Table S4.3).}

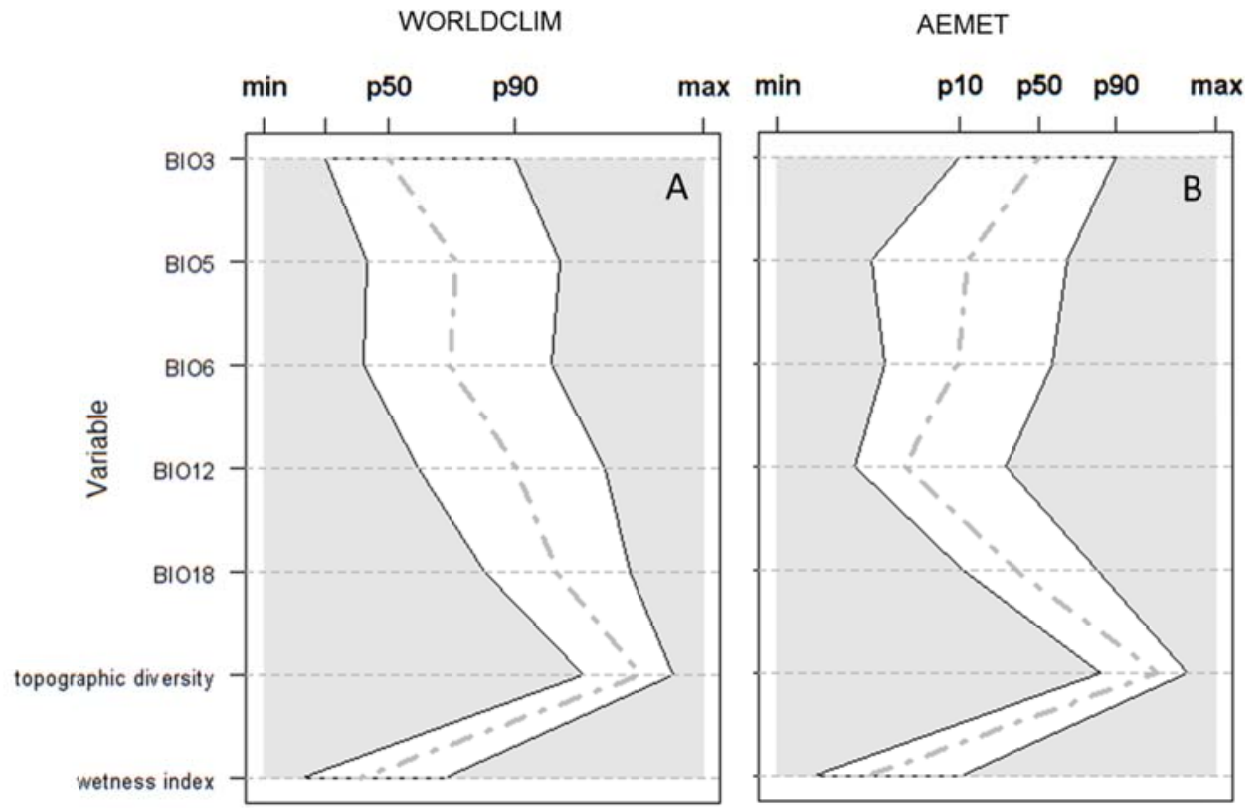

Fig. 4.4. Optimal (white) and total (grey) sub-habitat of $P$. uncinata in the Iberian Peninsula defined by the environmental variables (scale 0-1) in the (A) WORLDCLIM and (B) AEMET database. Min (minimum value), P50 (median or 50th percentile), P90 (90th percentile), Max (maximum value). 


\subsubsection{Evaluation of current $P$. uncinata models}

The AUC on the test dataset varied from 0.59 to 0.998 for both climatic datasets with mean values over 0.92 (Table S4.4). There was no agreement in the settings of the model that produced the highest or lowest $\mathrm{AUC}_{\mathrm{TEST}}$ for the same sub-habitat among the different climates; however we found that the $\mathrm{AUC}_{\mathrm{TEST}}$ for the marginal sub-habitat was slightly lower than in the rest of sub-habitats.

\section{Differences between AICc and default selected models}

Settings of AICc-selected models differed from default for all habitats and climates, especially regarding the $\beta$-multiplier. Regardless the habitat or climatic dataset, the AICcselected models had higher $\beta$-multiplier than the default ( $\beta$-multiplier=1) which resulted in less parameters than those made by default (Table 4.2). Referring to the features, in general, default models used the same or more features than the AICc-selected models (except for the marginal habitat in WORLDCLIM dataset) (Table 4.2). The differences in mean $\mathrm{AUC}_{\mathrm{TEST}}$ values were not significant (Student's t-test, $\mathrm{n}=20, \mathrm{t}=1.381$, $\mathrm{p}$-value $=0.200$ ) for both AICc and default models.

AICc-selected models had significantly lower $\mathrm{AUC}_{\mathrm{DIFF}}$ (Student's $\mathrm{t}$-test, $\mathrm{n}=20, \mathrm{t}=$ 24.859, $\mathrm{p}$-value $<0.01$ ) and omission rate $\mathrm{OR}_{\mathrm{MTP}}$ (Student's t-test, $\mathrm{n}=20, \mathrm{t}=-3.891$, $\mathrm{p}$-value $=$ $<0.01$ ), but higher omission rate $\mathrm{OR}_{10}$ (Student's t-test, $\mathrm{n}=20, \mathrm{t}=3.099$, $\mathrm{p}$-value $<0.01$ ) than default models indicating that default models overfit to the training data (Table 4.2 and Fig. S4.2).

The similarity (D) between AICc-selected and default models varied from 0.242 to 0.596 $(0.406 \pm 0.130)$, indicating that there were differences in the geographic predicted suitability of the models among each AICc-selected model and their equivalent default settings model (Table 4.2, Fig. S4.2).

\section{Differences between climatic databases}

The differences in mean values between AEMET and WORLDCLIM models were not significant for $\mathrm{AUC}_{\mathrm{TEST}}$ (Student's t-test, $\mathrm{n}=20, \mathrm{t}=0.548, \mathrm{p}$-value $=0.594$ ), $\mathrm{AUC}_{\mathrm{DIFF}}$ (Student's t-test, $\mathrm{n}=20, \mathrm{t}=-0.753$, $\mathrm{p}$-value $=0.469$ ), omission rate $\mathrm{OR}_{\mathrm{MTP}}$ (Student's t-test, $\mathrm{n}$ $=20, \mathrm{t}=-0.078, \mathrm{p}$-value $=0.939)$, omission rate OR10 (Student's t-test, $\mathrm{n}=20, \mathrm{t}=-1.347, \mathrm{df}$ 
$=15.07, \mathrm{p}$-value $=0.198)$ and $\mathrm{D}$ (Student's t-test, $\mathrm{n}=20, \mathrm{t}=-1.026, \mathrm{df}=7.833, \mathrm{p}$-value $=$ 0.335) (Table 4.2 and Fig. S4.3).

\section{Differences among sub-habitats}

There were significant differences between sub-habitats means as determined by one-way ANOVA on the omission rates $\mathrm{OR}_{\mathrm{MTP}}[\mathrm{F}(4,15)=7.183$, p-value $<0.01]$ and $\mathrm{OR}_{10}[\mathrm{~F}(4,15)=$ 4.345, $\mathrm{p}$-value $=0.016]$. But there were not significant effect on the $\operatorname{AUC}_{\mathrm{TEST}}[\mathrm{F}(4,15)=$ 2.574, $\mathrm{p}$-value $=0.080)], \mathrm{AUC}_{\mathrm{DIFF}}[\mathrm{F}(4,15)=1.828, \mathrm{p}$-value $=0.176]$, and the $\mathrm{D}[\mathrm{F}(4,5)=$ 1.754 , p-value $=0.275]$. The marginal sub-habitat had the highest omission rates $\mathrm{OR}_{\mathrm{MTP}}$ and $\mathrm{OR}_{10}$ meaning that marginal models presented higher overfitting to the data compared to the rest of sub-habitats.

The sub-habitat with the highest similarity in geographic space ( $\mathrm{D}$ in Table 4.2) value was the suboptimal models in both climatic databases (Table 4.2).

\begin{tabular}{|c|c|c|c|c|c|c|c|c|c|c|c|c|c|c|}
\hline Climatic data & Model code & Habitat & $\mathrm{N}^{\circ}$ presences & Model & $\mathrm{N}^{0}$ parameters & Features & $\beta$-multiplier & AUC (TEST) & AUC (DIFF) & OR (10) & OR (MTP) & DAICc & w.AIC & $\mathrm{D}$ \\
\hline \multirow{15}{*}{ 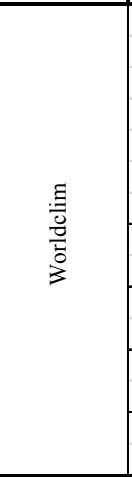 } & 34 & \multirow{7}{*}{ Marginal } & \multirow{7}{*}{44} & AICc & 12 & $\overline{\mathrm{LQH}}$ & 2.5 & 0.9772 & 0.0171 & 0.3636 & 0.2045 & 0.2856 & 0.1744 & 0.4220 \\
\hline & 40 & & & $\mathrm{AICc}$ & 11 & LQH & 3 & 0.9768 & 0.0172 & 0.3636 & 0.1818 & 0.8850 & 0.1292 & 0.3936 \\
\hline & 41 & & & $\mathrm{AICc}$ & 12 & LQHP & 3 & 0.9741 & 0.0200 & 0.3182 & 0.1818 & 0.0000 & 0.2011 & 0.3716 \\
\hline & 45 & & & $\mathrm{AICc}$ & 12 & $\mathrm{H}$ & 3.5 & 0.9757 & 0.0178 & 0.3182 & 0.1818 & 0.7224 & 0.1402 & 0.3439 \\
\hline & 51 & & & $\mathrm{AICc}$ & 11 & $\mathrm{H}$ & 4 & 0.9747 & 0.0178 & 0.2955 & 0.1818 & 0.0603 & 0.1952 & 0.3095 \\
\hline & 54 & & & $\mathrm{AICc}$ & 11 & LQHPT & 4 & 0.9747 & 0.0186 & 0.2955 & 0.2045 & 1.9765 & 0.0749 & 0.3046 \\
\hline & 16 & & & Default & 31 & $\mathrm{LQH}$ & 1 & 0.8514 & 0.0735 & 0.3182 & 0.0682 & 230.2530 & 0.0000 & \\
\hline & 58 & \multirow{2}{*}{ Optimal } & \multirow{2}{*}{496} & $\mathrm{AICc}$ & 31 & $\overline{\mathrm{LQH}}$ & 4.5 & 0.9983 & 0.0002 & 0.1169 & 0.0020 & 0.0000 & 0.9967 & 0.5357 \\
\hline & 18 & & & Default & 91 & LQHPT & 1 & 0.9966 & 0.0010 & 0.0948 & 0.0040 & 1216.9659 & 0.0000 & \\
\hline & 66 & \multirow{2}{*}{ Suboptimal } & \multirow{2}{*}{731} & AICc & 31 & LQHPT & 5 & 0.9977 & 0.0002 & 0.1039 & 0.0000 & 0.0000 & 1.0000 & 0.5415 \\
\hline & 18 & & & Default & 115 & LQHPT & 1 & 0.9773 & 0.0191 & 0.1408 & 0.0191 & 2306.2525 & 0.0000 & \\
\hline & 63 & \multirow{2}{*}{ Subtotal } & \multirow{2}{*}{1077} & AICc & 30 & $\mathrm{H}$ & 5 & 0.9959 & 0.0011 & 0.1487 & 0.0167 & 0.0000 & 0.9977 & 0.2774 \\
\hline & 18 & & & Default & 40 & LQHPT & 1 & 0.9962 & 0.0009 & 0.1217 & 0.0019 & 3469.5669 & 0.0000 & \\
\hline & 63 & \multirow{2}{*}{ Total } & \multirow{2}{*}{1121} & $\mathrm{AICc}$ & 27 & $\mathrm{H}$ & 5 & 0.9953 & 0.0015 & 0.1598 & 0.0054 & 0.0000 & 0.9996 & 0.3288 \\
\hline & 18 & & & Default & 61 & LQHPT & 1 & 0.9956 & 0.0006 & 0.1312 & 0.0000 & NA & NA & \\
\hline \multirow{15}{*}{ 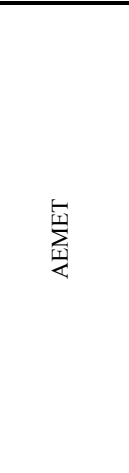 } & 14 & \multirow{5}{*}{ Marginal } & \multirow{5}{*}{49} & $\mathrm{AICc}$ & 8 & LQ & 1 & 0.9831 & 0.0107 & 0.2324 & 0.0385 & 0.0000 & 0.4477 & 0.2448 \\
\hline & 20 & & & $\mathrm{AICc}$ & 8 & LQ & 1.5 & 0.9859 & 0.0079 & 0.2324 & 0.0385 & 1.4717 & 0.2145 & 0.2443 \\
\hline & 26 & & & $\mathrm{AICc}$ & 8 & LQ & 2 & 0.9867 & 0.0071 & 0.1939 & 0.0385 & 3.0811 & 0.0959 & 0.2437 \\
\hline & 32 & & & $\mathrm{AICc}$ & 7 & LQ & 2.5 & 0.9870 & 0.0069 & 0.1939 & 0.0385 & 2.0672 & 0.1593 & 0.2422 \\
\hline & 16 & & & Default & 58 & $\mathrm{LQH}$ & 1 & 0.6265 & 0.3558 & 0.5913 & 0.2228 & NA & NA & \\
\hline & 60 & \multirow{3}{*}{ Optimal } & \multirow{3}{*}{245} & $\mathrm{AICc}$ & 33 & LQHPT & 4.5 & 0.9978 & 0.0010 & 0.2414 & 0.0286 & 0.0000 & 0.7050 & 0.5414 \\
\hline & 66 & & & $\mathrm{AICc}$ & 30 & LQHPT & 5 & 0.9978 & 0.0008 & 0.2659 & 0.0245 & 1.7429 & 0.2950 & 0.5494 \\
\hline & 18 & & & Default & 118 & LQHPT & 1 & 0.9918 & 0.0065 & 0.2575 & 0.0123 & 894.4808 & 0.0000 & \\
\hline & 60 & \multirow{2}{*}{ Suboptimal } & \multirow{2}{*}{430} & AICc & 33 & LQHPT & 4.5 & 0.9971 & 0.0010 & 0.2207 & 0.0023 & 0.0000 & 1.0000 & 0.5965 \\
\hline & 18 & & & Default & 132 & LQHPT & 1 & 0.9970 & 0.0011 & 0.2047 & 0.0093 & 1314.3326 & 0.0000 & \\
\hline & 66 & \multirow{3}{*}{ Subtotal } & \multirow{3}{*}{736} & $\mathrm{AICc}$ & 35 & LQHPT & 5 & 0.9939 & 0.0018 & 0.1617 & 0.0041 & 0.0000 & 0.9146 & 0.5392 \\
\hline & 60 & & & AICc & 41 & LQHPT & 4.5 & 0.9938 & 0.0022 & 0.1590 & 0.0027 & 4.7422 & 0.0854 & 0.5489 \\
\hline & 18 & & & Default & 142 & LQHPT & 1 & 0.9899 & 0.0051 & 0.1929 & 0.0041 & 2336.4338 & 0.0000 & \\
\hline & 66 & \multirow{2}{*}{ Total } & \multirow{2}{*}{1121} & $\mathrm{AICc}$ & 36 & LQHPT & 5 & 0.9955 & 0.0008 & 0.0794 & 0.0045 & 0.0000 & 1.0000 & 0.5413 \\
\hline & 18 & & & Default & 145 & LQHPT & 1 & 0.9890 & 0.0058 & 0.1685 & 0.0054 & 3155.7654 & 0.0000 & \\
\hline
\end{tabular}

Table 4.3. Evaluation results of MAXENT models generated by ENMeval. Only Maxent default models and models with lowest AICc for each habitat and climatic dataset are shown. AUC(TEST): mean AUC value of the four iterations of the ability to predict the testing presences, $\mathrm{AUC}(\mathrm{DIFF})$ : mean $\mathrm{AUC}$ value between $\mathrm{AUC}_{\mathrm{TRAIN}}-\mathrm{AUC}_{\mathrm{TEST}}, \mathrm{OR}(10): 10 \%$ training omission rate, OR(MTP): Minimum Training Presence omission rate, DAICc: difference between the AICc of each model and the model with the lowest AICc, w.AIC: Akaike weight of the model, D: Schoener's D statistic. 


\section{Evaluation of current spatial predictions}

The areas predicted as suitable in the present were similar although the AICc-selected models showed slightly higher suitable areas in both climatic datasets (Fig. S4.4). Therefore for simplicity we presented here the projected distributions of the AICc-selected models for the two climatic datasets.

When comparing among climatic datasets, WORLDCLIM had slightly higher suitability values than AEMET for all the habitat classes being this difference more visible in the marginal habitat (Fig. 4.4). In WORLDCLIM the sub-habitats that predicted the marginal occurrences were the marginal and the total which predicted very low suitability in the Gúdar population. In AEMET, marginal occurrences were predicted with low suitability in the subtotal, suboptimal and optimal sub-habitats, higher suitability in the total and especially the marginal sub-habitat. Despite of the climatic database used, the models run with marginal occurrences were the models with the highest suitability of the species in the study area (Fig. 4.4).

Nevertheless in marginal occurrences WORLDCLIM presented some inconsistencies (e.g. Gúdar, Table 4.4), predicting higher suitability for the worst climatic scenario (RCP8.5 2061) than for the intermediate (RCP4.5 2041) whilst these inconsistencies are not observed in the AEMET predictions (Table 4.4). 


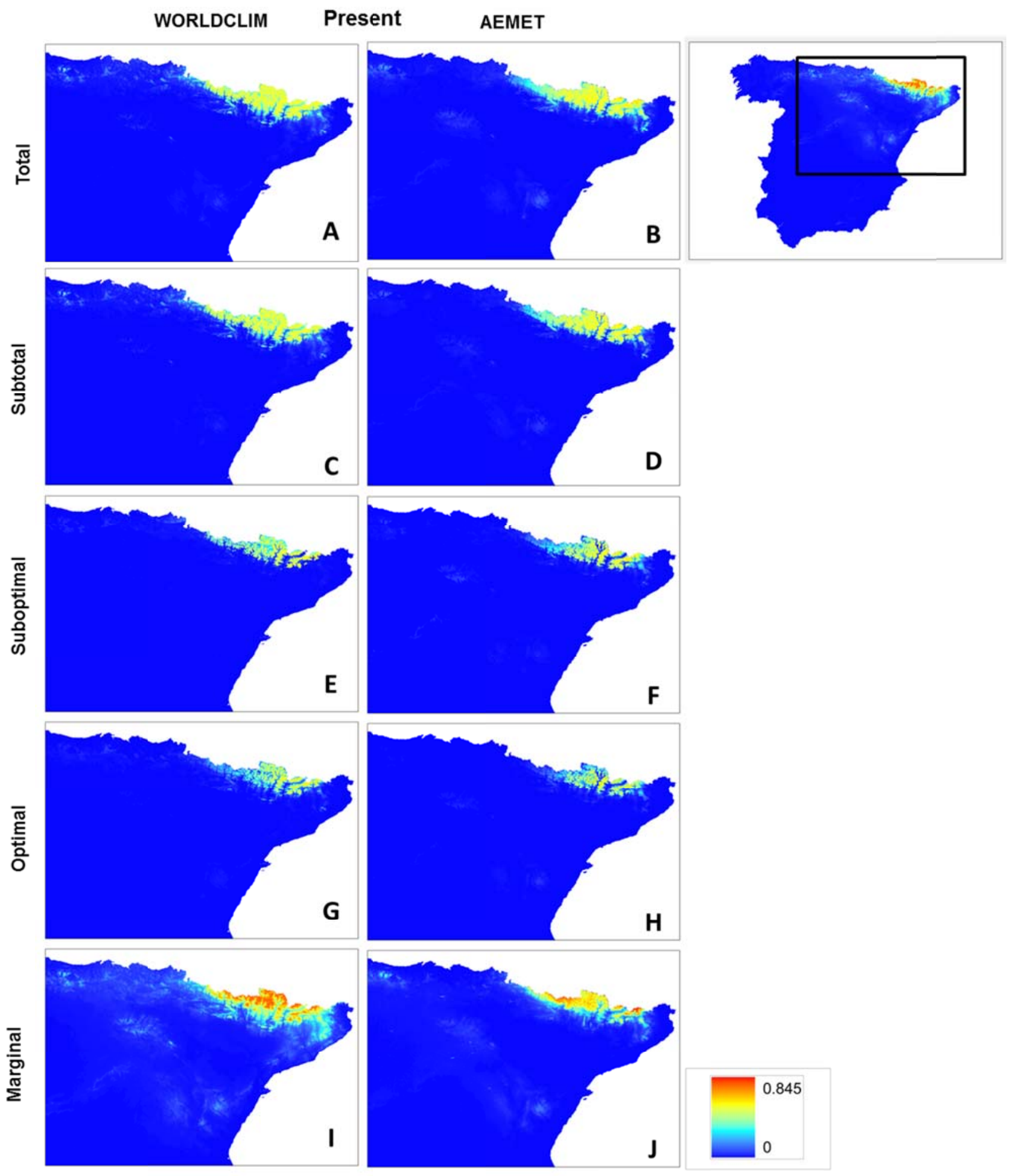

Fig. 4.4. Current potential distributions for the AICc-selected model for the different habitats of $P$. uncinata in the northeastern area of the Iberian Peninsula: total (A and B), subtotal (C and D), suboptimal (E and F), optimal (G and H), marginal (I and J) and climatic databases: WORLDCLIM (A, C, E, G and I) and AEMET (B, D, F, H and J). The predicted suitability values of the species in the area ranges from 0 to 1 and is represented by a color gradient which varies from red indicating high suitability to blue indicating low suitability (logistic output). Geographic Coordinate System used: Universal Transverse Mercator, European Datum 1950, Zone 30N. Scale: 1:2,500,000. 


\subsubsection{Evaluation of species future projections}

When projecting the selected models (Table 4.2) onto the four climate change scenarios we observed a reduction in the suitable area predicted for P. uncinata in the Iberian Peninsula, particularly in the worst scenario, the RCP8.5 for the 2061-2080 period. In these future predictions, there is an important contraction of the southern range of the species. Marginal populations in the Iberian Peninsula are predicted as not environmentally suitable for all subhabitats in all the future scenarios and periods except for the marginal sub-habitat, which predicted low suitability in these two populations (Table 4.4, Fig. 4.5).

Table 4.4. Predicted current and future suitability in Gúdar P. uncinata plot.

\begin{tabular}{|c|c|c|}
\hline Model & $\begin{array}{c}\text { WORLDCLIM } \\
\text { predicted } \\
\text { suitability }\end{array}$ & $\begin{array}{c}\text { AEMET } \\
\text { predicted } \\
\text { suitability }\end{array}$ \\
\hline Marginal sub-habitat current & 0.222 & 0.141 \\
\hline Marginal sub-habitat RCP4.5 2041 & 0.124 & 0.070 \\
\hline Marginal sub-habitat RCP8.5 2061 & 0.154 & 0.015 \\
\hline
\end{tabular}




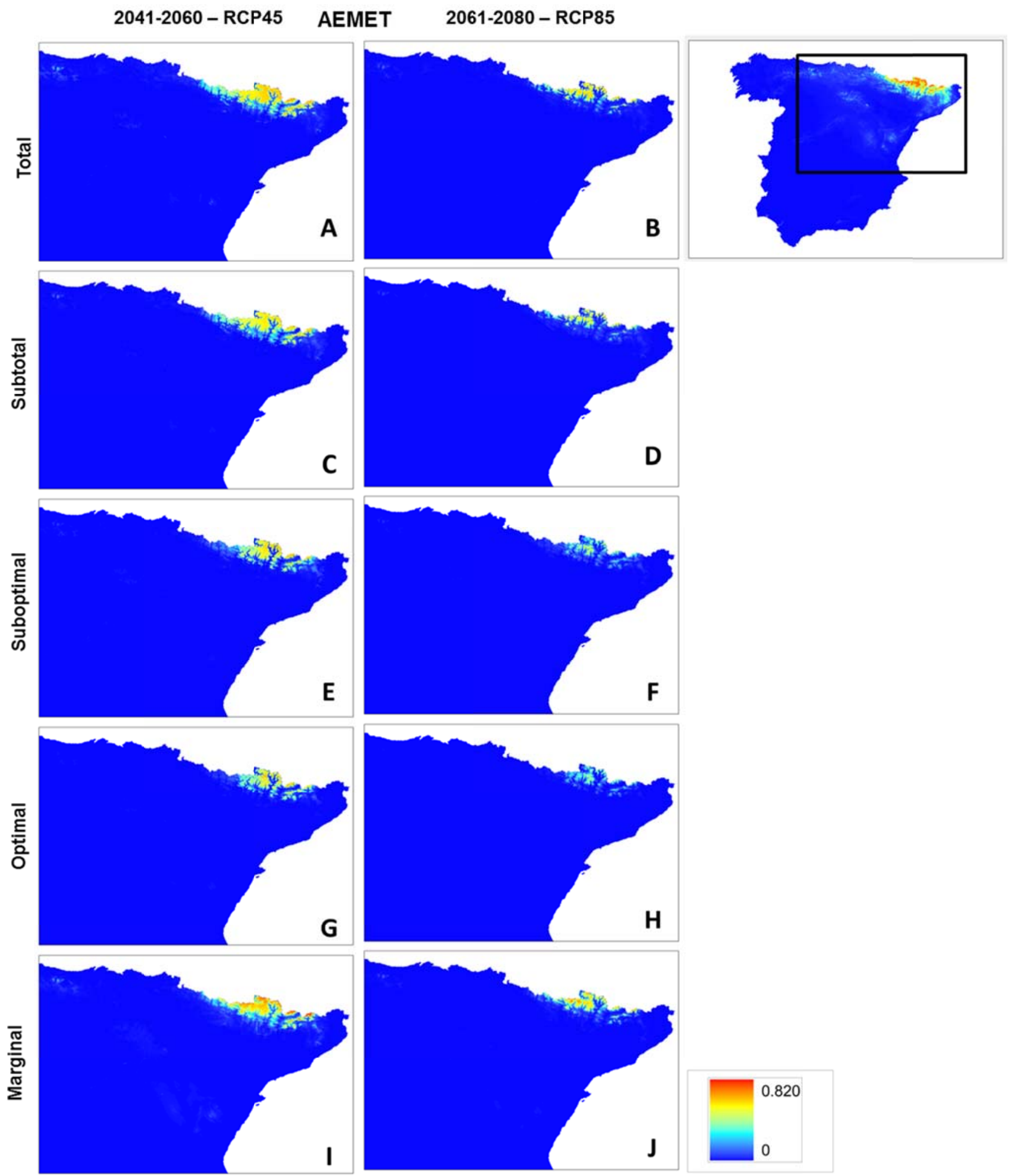

Fig. 4.5. Projections of the potential distribution of the AICc-selected model for the different sub-habitats of $P$. uncinata in the north-eastern area of the Iberian Peninsula onto two future climate scenarios of the AEMET climatic database: 2041-2060 period and RCP45 (A, C, E, G and I) and 2061-2080 period and RCP85 (B, D, F, H and J). The predicted suitability values of the species in the area ranges from 0 to 1 and is represented by a color gradient which varies from red indicating high suitability to blue indicating low suitability (logistic output). Geographic Coordinate System used: Universal Transverse Mercator, European Datum 1950, Zone 30N. Scale: 1:2,500,000. 


\subsection{DISCUSSION}

Our results show that the data included in the model affect their performance as well as the predicted distribution of the species, in accordance with other authors (Hernandez et al., 2006, Buisson et al., 2010 and Wisz et al., 2008). These choices, along with other decisions of the modelling process, have great influence on the spatial predictions of the models particularly in the distribution limits of species (Vale et al., 2014). We observed that species occurrences, climatic databases and model complexity produced differences in the model outputs regarding model predictive capacity and predicted suitability especially at the species range margins that led to large differences in the predicted climate change impacts in the species marginal populations.

\subsubsection{Effect of species-specific tuning in Maxent models}

Our results in terms of model selection showed different parameters for optimal current predictions, sometimes using the same features but with higher regularization parameter which resulted in less complex models than the default Maxent ones (Table 4.2). AICcselected models presented the same discrimination power as default models but with less overfitting (i.e. the models are fitted not too close the training data), as a result of using less parameters in the models. Therefore, these optimal models are more generalizable and transferable to different climatic conditions than the default models (Warren et al., 2014). These results agree with other studies (Cao et al., 2013, Muscarella et al., 2014 and Shcheglovitova and Anderson, 2013) that recommended conducting species-specific tuning of parameters in Maxent to obtain the best combination of parameters for the target species and study area.

\subsubsection{How do data from different climatic databases affect model predictions?}

There were no differences among the climatic databases in the evaluation metrics. However, WORLDCLIM predicted higher current suitability values of the species in the study area in each pixel than models obtained with AEMET in all the sub-habitats (Fig. 4.4), especially in marginal habitats. This difference was also visible in climate change scenarios, where the AEMET predicted lower suitability per pixel and narrower extension of the area predicted suitable than WORLDCLIM. The differences found in the geographic predictions between the datasets forces us to interpret the results carefully, particularly the predictions obtained through global bioclimatic datasets such as WORLDCLIM because they have not been strictly tested in small areas (Bedia et al., 2013). Specifically, WORLDCLIM 
predictions might not be as reliable as AEMET's in the Iberian Peninsula because it incorporates fewer meteorological stations and thus, the study area is poorly covered both geographically and in terms of altitude distribution of the climate data (Fig. 4.2). Moreover, WORLDCLIM highest meteorological station is found at 1,888 masl whilst in AEMET are found at 2,263 masl for temperature in the Pyrenees and at 2,507 masl for precipitation in Sierra Nevada. Since Pinus uncinata can reach up to 2,700 masl in the Iberian Peninsula the risk of extrapolation is higher for WORLDCLIM (extrapolation begins above 1,900 masl) than AEMET predictions (extrapolation begins above 2,500 masl).

\subsubsection{Effect of the sub-habitat definition?}

The sub-habitats presented no differences in the evaluation metrics except for the omission rates, which were higher for the marginal sub-habitat, hence showing higher fit to the training data than the rest of sub-habitats. Higher differences were found in the geographic predictions, being the marginal sub-habitats models the ones that predicted the highest suitability in both present and future climate scenarios.

The optimal sub-habitat is regarded as the core environmental conditions of a species and it includes the most suitable ecological range for the species, representing the minimum potential distribution of the species in an area (Díaz-Maroto et al., 2006). When modelling the optimal sub-habitat, the potential distribution of the species is reduced to the Pyrenees and marginal occurrences are not predicted as suitable in the present or in the future. Accordingly, we assume that the Pyrenees would be an area with the core environmental conditions to host the species in the Iberian Peninsula. In conjunction with other studies (Fernández et al., 2015), we found that the optimal sub-habitat model did not predict accurately the marginal occurrences of the species. Still, if the aim is to model the total distribution of a species in an area, all the environmental conditions of the species range should be included in the model thus obtaining the potential distribution for the species in the area and this is the general approach in species modelling distribution (Hijmans and Elith, 2013). However, this approach could miscalculate by under or overestimating species potential distribution when modelling species with high intra-specific genetic variability and phenotypic plasticity (Benito-Garzón et al., 2011 and Fernández et al., 2015).

In $P$. uncinata, the potential area predicted by the total sub-habitat was observably higher than the predicted by the optimal sub-habitat and the suitability predicted in the marginal occurrences was lower than the marginal sub-habitat predictions. These results echoed other 
studies that obtained differences in the predictions between the total and marginal populations (Fernández et al., 2015, Soley-Guardia et al., 2016, Vale et al., 2014 and Williams-Tripp et al., 2012) showing that species response to climate across their range is not equal and adaptations to local conditions might play a role (Benito-Garzón et al., 2011).

Furthermore, if the occurrences of a species are unevenly distributed among the different populations as $P$. uncinata case (4 marginal occurrences over a total of 1121 ), the use of the total sub-habitat model underestimates the suitability of the marginal occurrences because of their little statistical weight in the model. The marginal occurrences of P. uncinata are environmentally marginal but still within the suitable environment (Fig. 4.3) and reproductive niche for the species (Fig. 4.6, Camarero and Gutiérrez Merino, 1999 and IFN3, 2008). In other studies, the marginal populations are selected according to geographical isolation (Fernández et al., 2015 and Vale et al., 2014) but geographical distance does not necessarily mean environmental difference. Thus in this study we defined the different sub-habitats according to the environmental range of the variable. The marginal sub-habitat, was defined as the one between the limits of the subtotal habitat and the extremes value of the variables (including both top and bottom extremes of the species distribution) provides an estimation of the species adaptation to conditions outside the central habitat (Díaz-Maroto et al., 2006). The marginal sub-habitat predicted lower suitability values in the marginal occurrences, but still higher than the predicted by the other sub-habitats of the species. These two populations are located in the mediterranean biogeographic region enduring fewer summer precipitations and higher temperatures than the Pyrenees populations (Camarero and Gutiérrez Merino, 2008) which are located in the alpine region. These populations are considered relict distributions of former suitable climates (Costa et al., 1997 and Rubiales et al., 2010) and for this reason; they are expected to intensely suffer climate change (Jiménez-Alfaro et al., 2016). Furthermore they can be found from 1850-1900 to the summit (aprox 2,000 masl) contacting in the bottom with P. sylvestris and hybridizing in the contact areas (Rubiales et al., 2010). Since these populations would be the most likely to suffer the negative impacts of climate change (difficulty or impossibility of regeneration, increased fragmentation, genetic isolation, loss of growth and disappearance of populations) and they are isolated in mountain islands where they cannot go up in height (elevator to extinction), they should be carefully studied and actions for their conservation should be considered. 

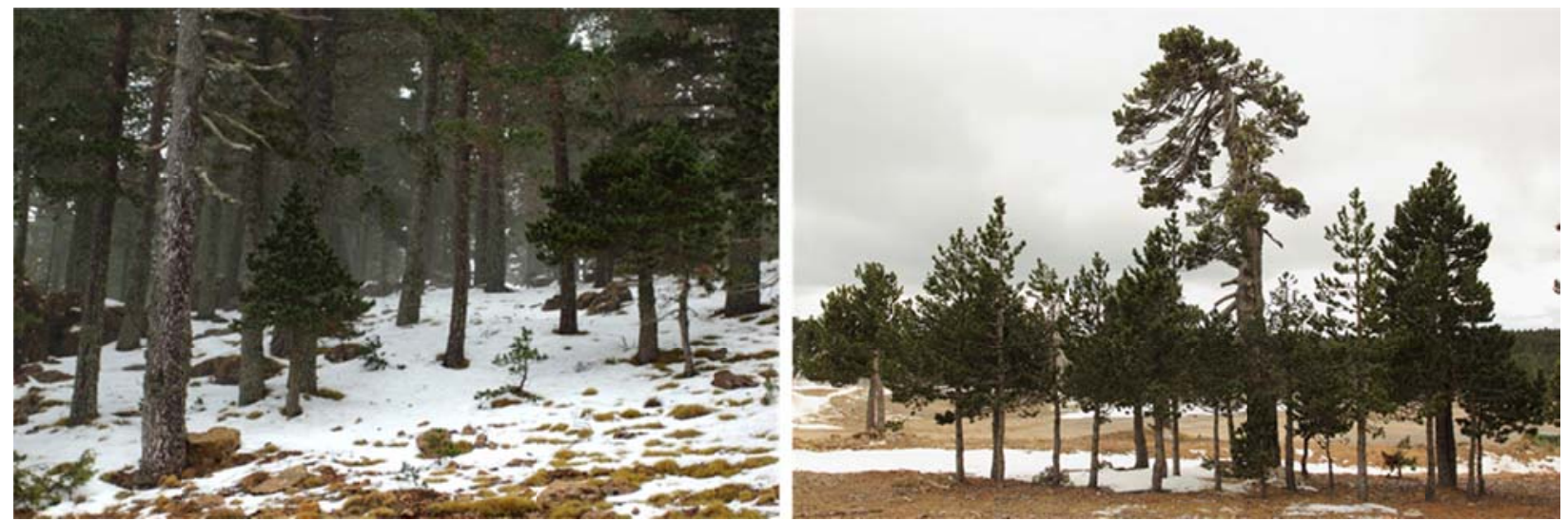

Fig. 4.6 Pinus uncinata regeneration in Gúdar population

\subsection{CONCLUSIONS}

We observed that modelling sub-habitat of the species instead of the total species distribution lead to better results regarding species predicted suitability. We recommend our environmental partition of sub-habitats and the inclusion of both extremes of the variable ranges in the marginal sub-habitat when having a species with an uneven distribution between core and edge occurrences of a species. Additionally, we strongly recommend the use of more than one climatic dataset and species-specific tuning of Maxent model parameters to gain a better understanding of the current and future species potential distribution. 


\subsection{SUPPLEMENTARY INFORMATION}

Table S4.1. Climate models used in the study (CMIP5) to simulate future climatic conditions in the study area. http://cmippcmdi.llnl.gov/cmip5/

\begin{tabular}{|c|c|c|c|c|c|}
\hline Model & Code & Institution & Country & $\begin{array}{c}\text { Spatial } \\
\text { resolution } \\
\text { (lon x lat) }\end{array}$ & Reference \\
\hline BCC-CSM1-1 & BC & $\begin{array}{c}\text { Beijing Climate Center (BCC), China } \\
\text { Meteorological Administration }\end{array}$ & China & $\begin{array}{c}2.7905^{\circ} \times \\
2.8125^{\circ}\end{array}$ & Gao et al., 2012 \\
\hline CNRM-CM5 & CN & $\begin{array}{c}\text { Centre National de Recherches } \\
\text { Reteorologiques/Centre Europeen de } \\
\text { Calcul Scientifique (CNRM- } \\
\text { CERFACS) }\end{array}$ & France & $1.4^{\circ} \times 1.4^{\circ}$ & Voldoire et al., \\
2012 & UK & $1.87^{\circ} \times 1.25^{\circ}$ & Collins et al., \\
2011
\end{tabular}

\section{References:}

Collins, W.J., Bellouin, N., Doutriaux-Boucher, M., Gedney, N., Halloran, P., Hinton, Hughes, J., Jones, C.D., Joshi, M., Liddicoat, S., Martin, G., O’Connor, F., Rae, J., Senior, C., Sitch, S., Totterdell, I., Wiltshire, A., Woodward, S., 2011. Development and evaluation of an Earth-system model-HadGEM2. Geosci. Model Dev. 4, 1051-1075.

Gao, F., Xin, X., Wu, T., 2012. Study on the Prediction of Regional and Global Temperature in Decadal Time Scale with BCC CSM1. 1. Chinese Journal of Atmospheric Sciences.

Iversen, T., Bentsen, M., Bethke, I., Debernard, J.B., Kirkevåg, A., Seland, Ø., Drange, H., Kristjansson, J.E., Medhaug, I., Sand, M., Seierstad, I.A., 2013. The Norwegian earth system model, NorESM1-M-Part 2: climate response and scenario projections. Geosci. Model Dev. 6, 389-415.

Jungclaus, J.H., Fischer, N., Haak, H., Lohmann, K., Marotzke, J., Matei, D., Mikolajewicz, U., Notz, D., vonStorch, J.S., 2013. Characteristics of the ocean simulations in MPIOM, the ocean component of the MPI-Earth system model, J. Adv. Model. Earth Syst. 5, 422-446.

Voldoire, A., Sanchez-Gomez, E., Salas y Mélia, D., Decharme, B., Cassou, C., Sénési, S., Valcke, S., Beau, I., Alias, A., Chevallier, M., Déqué, M., Deshayes, J., Douville, H., Fernandez, E., Madec, G., Maisonnave, E., Moine, M.P., Planton, S., Saint-Martin, D., Szopa, S., Tyteca, S., Alkama, R., Belamari, S., Braun, A., Coquart, L., Chauvin, F., 
2013. The CNRM-CM5. 1 global climate model: description and basic evaluation. Clim. Dyn. 40, 2091-2121.

Watanabe, S., Hajima, T., Sudo, K., Nagashima, T., Takemura, T., Okajima, H., Nozawa, T., Kawase, H., Abe, M., Yokohata, T., Ise, T., Sato, H., Kato, E., Takata, K., Emori, S., Kawamiya, M., 2011. MIROC-ESM 2010: model description and basic results of CMIP 5-20 c 3 m experiments. Geosci. Model Dev. 4, 845-872.

Yukimoto, S., Adachi, Y., Hosaka, M., Sakami, T., Yoshimura, H., Hirabara, M., Tanaka, T.Y., Shindo, E., Tsujino, H., Deushi, M., Mizuta, R., Yabu, S., Obata, A., Nakano, H., Koshiro, T., Ose, T., Kitoh, A., 2012. A new global climate model of the Meteorological Research Institute: MRI-CGCM3 model description and basic performance. J. Meteor. Soc. Japan. 90, 23-64. 
Table S4.2. Climatic and topographic variables used as predictor variables in the models (http://www.worldclim.org/; Hijmans et al., 2005).

\begin{tabular}{|c|c|c|}
\hline Variable & Description & Reference \\
\hline Bio 3 & Isothermality (BIO2/BIO7) $(* 100)$ & Hijmans et al., 2005 \\
\hline Bio 5 & Maximum Temperature of Warmest Month & Hijmans et al., 2005 \\
\hline Bio 6 & Minimum Temperature Coldest Month & Hijmans et al., 2005 \\
\hline Bio 12 & Annual Precipitation & Hijmans et al., 2005 \\
\hline Bio 18 & Precipitation of Warmest Quarter & Hijmans et al., 2005 \\
\hline topo_diversity & Topographic diversity & Benito et al., 2016 \\
\hline wet_index & Wetness index & Benito et al., 2016 \\
\hline
\end{tabular}

\section{References:}

Benito, B.M., Svenning, J.C., Kellberg-Nielsen, T., Riede, F., Gil-Romera, G., Mailund, T., Kjaergaard, P.C., Sandel, B.S., 2016. The ecological niche and distribution of Neanderthals during the Last Interglacial. J. Biogeogr.

Hijmans, R.J., Cameron, S.E., Parra, J.L., Jones, P.G., Jarvis, A., 2005. Very high resolution interpolated climate surfaces for global land areas. Int. J. Climatol. 25, 1965-1978. 
Table S4.3. Coefficients of variation of the variables used in the models obtained in the univariate analysis.

\begin{tabular}{|c|c|c|}
\hline Variable & $\begin{array}{c}\text { CV } \\
\text { (WORLDCLIM) }\end{array}$ & $\begin{array}{c}\text { CV } \\
\text { (AEMET) }\end{array}$ \\
\hline Bio 3 & 4.265 & 4.972 \\
\hline Bio 5 & 10.024 & 9.455 \\
\hline Bio 6 & -35.280 & -22.036 \\
\hline Bio 12 & 9.333 & 15.831 \\
\hline Bio 18 & 7.538 & 10.776 \\
\hline Wetness index & 8.600 & 7.112 \\
\hline Topographic diversity & 0.890 & 0.846 \\
\hline
\end{tabular}


Table S4.4. Summary $\mathrm{AUC}_{\mathrm{TEST}}$ results of MAXENT models for the five habitats defined for P. uncinata and the two climatic datasets.

\begin{tabular}{|c|c|c|c|c|c|c|c|}
\hline $\begin{array}{c}\text { AUC } \\
\text { (TEST) }\end{array}$ & Habitat & $\begin{array}{l}\text { Max } \\
\text { AUC }\end{array}$ & $\begin{array}{c}\text { Model code (max } \\
\text { AUC) }\end{array}$ & $\begin{array}{l}\text { Min } \\
\text { AUC }\end{array}$ & $\begin{array}{c}\text { Model code (min } \\
\text { AUC) }\end{array}$ & Mean & $\begin{array}{l}\text { Standard } \\
\text { deviation }\end{array}$ \\
\hline \multirow{5}{*}{$\sum_{i}^{+1}$} & Marginal & 0.990 & 54 & 0.590 & 4 & 0.928 & 0.122 \\
\hline & Optimo & 0.998 & 41 & 0.721 & 4 & 0.973 & 0.051 \\
\hline & Suboptimo & 0.997 & 63 & 0.723 & 4 & 0.971 & 0.055 \\
\hline & Subtotal & 0.996 & 41 & 0.886 & 3 & 0.980 & 0.029 \\
\hline & Total & 0.996 & 66 & 0.825 & 3 & 0.966 & 0.040 \\
\hline \multirow{5}{*}{ 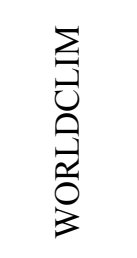 } & Marginal & 0.983 & 21 & 0.594 & 4 & 0.944 & 0.088 \\
\hline & Optimo & 0.998 & 66 & 0.777 & 10 & 0.976 & 0.047 \\
\hline & Suboptimo & 0.998 & 66 & 0.907 & 9 & 0.985 & 0.021 \\
\hline & Subtotal & 0.996 & 30 & 0.886 & 45 & 0.966 & 0.043 \\
\hline & Total & 0.996 & 48 & 0.886 & 10 & 0.971 & 0.042 \\
\hline
\end{tabular}




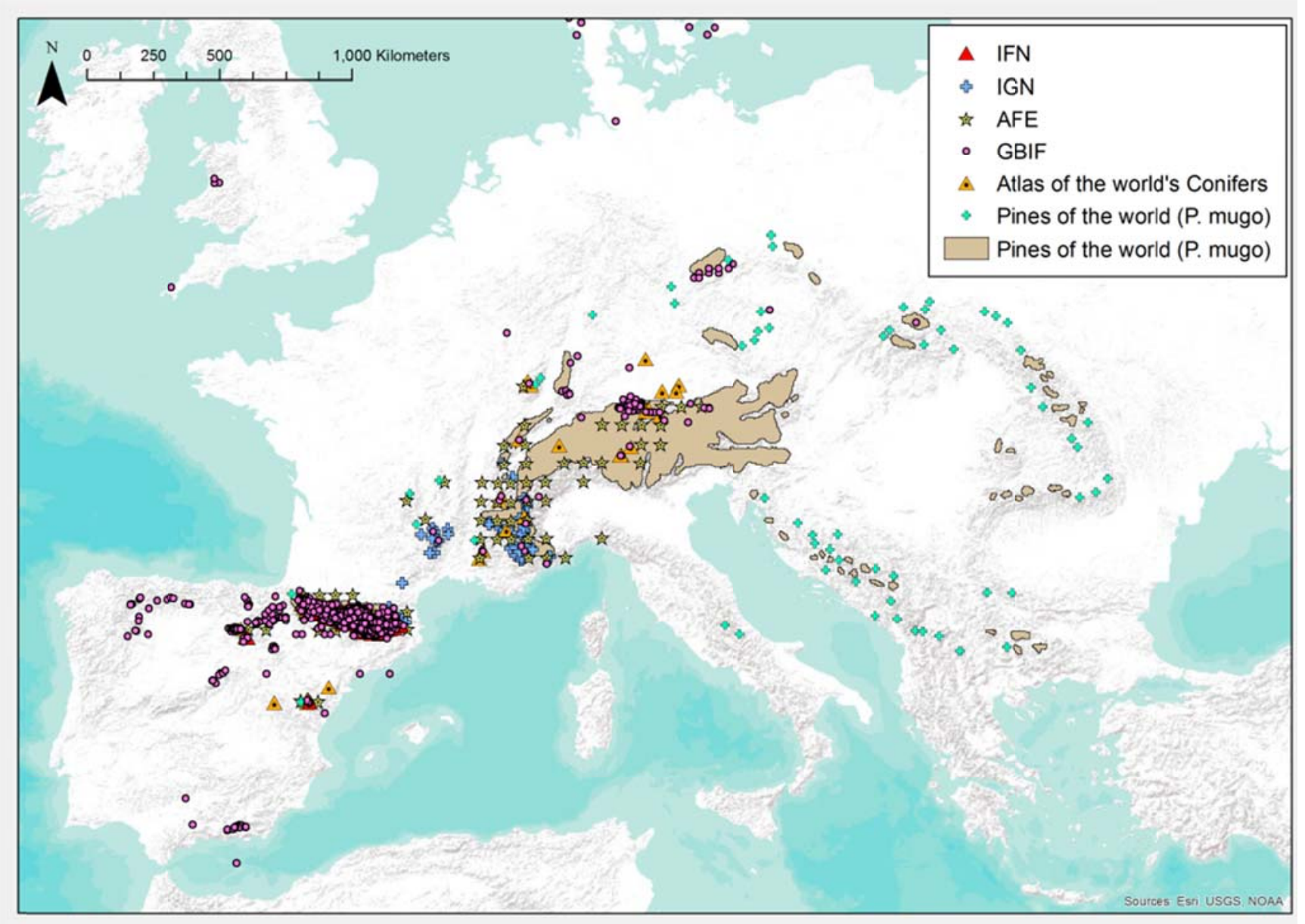

Fig. S4.1. Natural distribution of Pinus uncinata in Europe obtained from different sources. IFN: Spanish forest inventory (IFN3, 2008), IGN: French forest inventory (IGN, 2013), AFE: Atlas Florae Europaeae (Jalas and Suominen, 1972-1994), Atlas of the World's Conifers: Atlas of the World's Conifers (Farjon and Filer, 2013) and GBIF: Global Biodiversity Information Facility database (GBIF; http://www.gbif.org/). The Pines of the world: Geographic distribution of the pines of the world (Critchfield and Little, 1966) represents the area occupied by Pinus mugo and includes P. uncinata. 

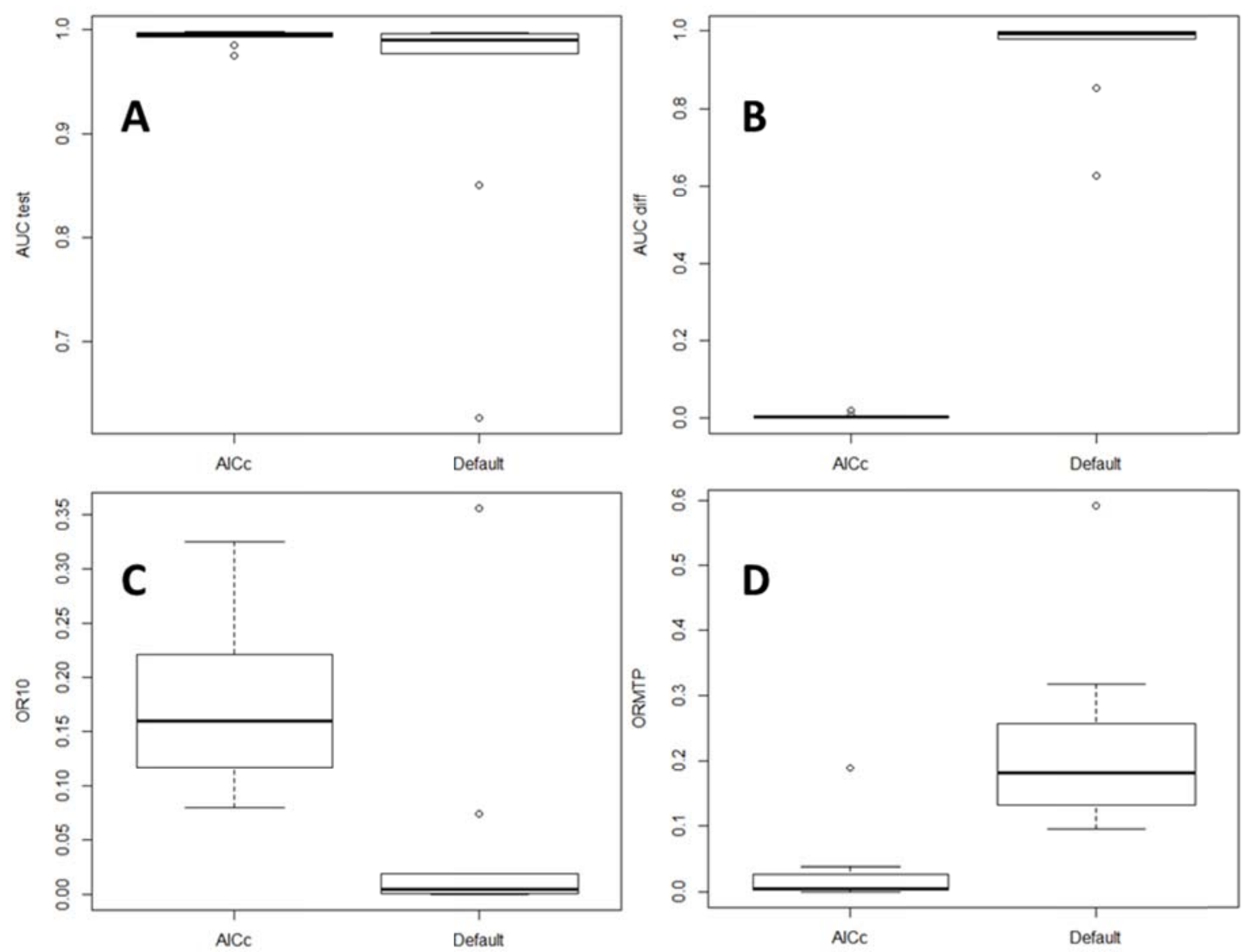

Fig. S4.2 Boxplot of AICc versus default current selected models for P. uncinata. A) AUC $_{\text {TEST }}$ values (mean AUC value of the four iterations of the ability to predict the testing presences), B) $\mathrm{AUC}_{\mathrm{DIFF}}$ values (mean $\mathrm{AUC}$ value between $\mathrm{AUC}_{\mathrm{TRAIN}}$ $\mathrm{AUC}_{\mathrm{TEST}}$ ), C) $\mathrm{OR}_{10}$ values (10\% training omission rate) and D) $\mathrm{OR}_{\mathrm{MTP}}$ values (Minimum Training Presence omission rate). 

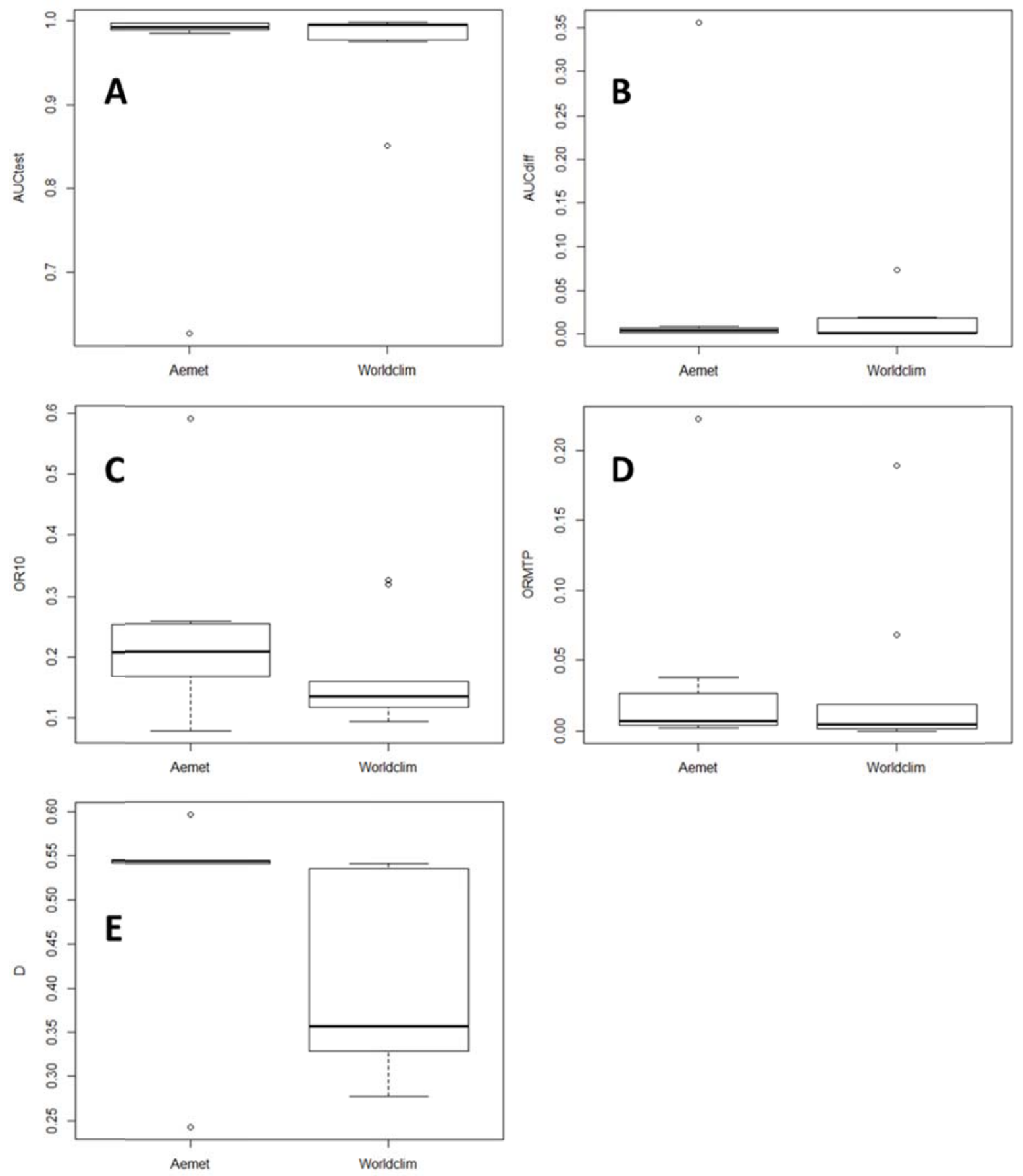

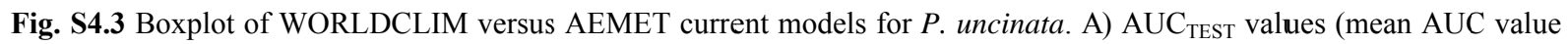
of the four iterations of the ability to predict the testing presences), B) $\mathrm{AUC}_{\mathrm{DIFF}}$ values (mean AUC value between $A U C_{\text {TRAIN }}$ - $\mathrm{AUC}_{\mathrm{TEST}}$ ), C) $\mathrm{OR}_{10}$ values (10\% training omission rate), D) $\mathrm{OR}_{\mathrm{MTP}}$ values (Minimum Training Presence omission rate) and E) Schoener's D statistic values. 


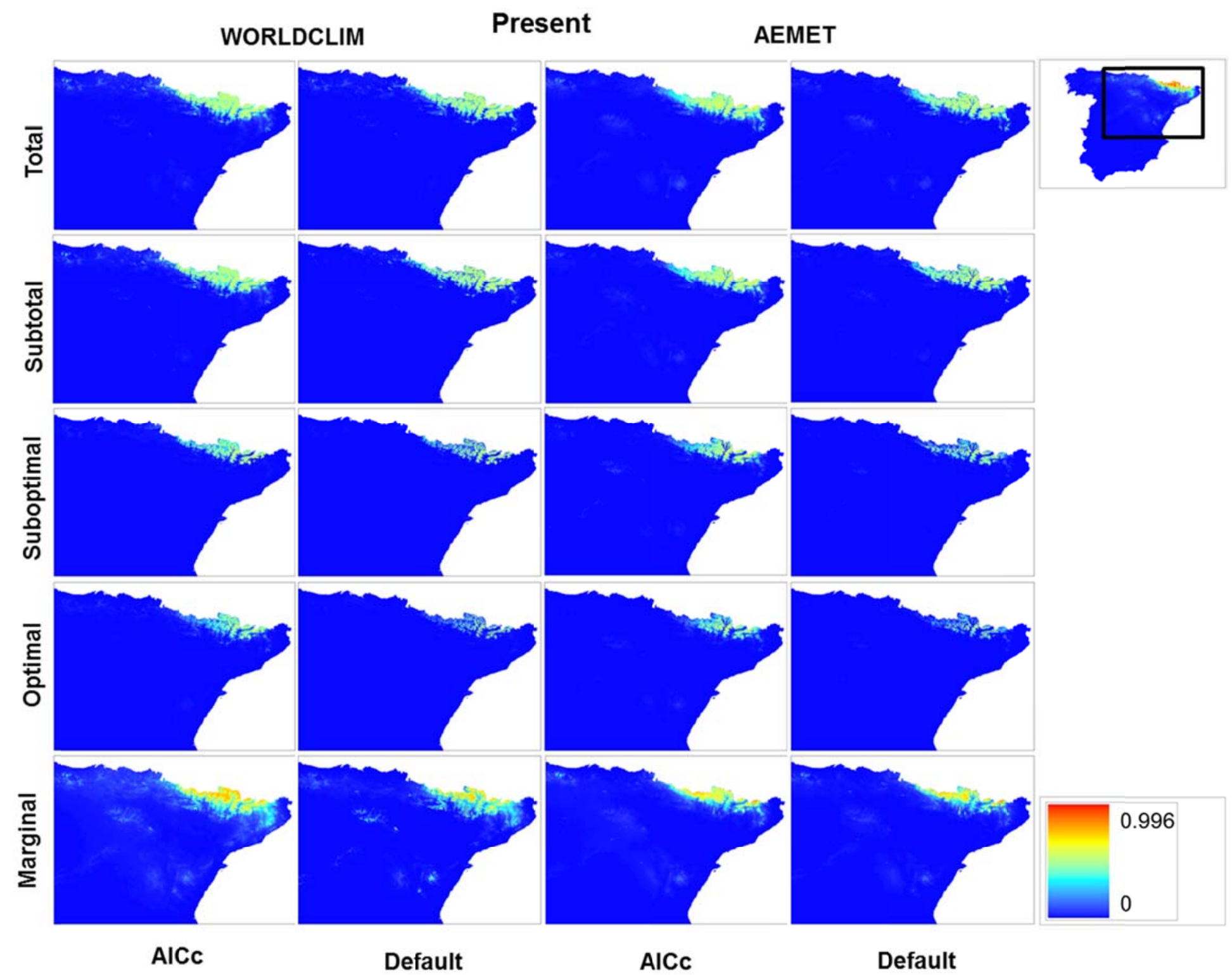

Fig. S4.4 Current potential distributions for the AICc versus default selected current models for the different sub-habitats of $P$. uncinata in the north-eastern area of the Iberian Peninsula. The predicted suitability values of the species in the area ranges from 0 to 1 and is represented by a color gradient which varies from red indicating high suitability to blue indicating low suitability (logistic output). Geographic Coordinate System used: Universal Transverse Mercator, European Datum 1950, Zone $30 \mathrm{~N}$. Scale: 1:2,500,000. 


\section{VALIDACIÓN DE MODELOS DE DISTRIBUCIÓN DE ESPECIES CON IMÁGENES DE SATÉLITE. APLICACIÓN EN EL ESTUDIO DE LA VULNERABILIDAD FUTURA DE PINUS HARTWEGII LINDL. EN EL PARQUE NACIONAL IZTA - POPO (MÉXICO).}

\subsection{RESUMEN}

En este capítulo se plantea el uso de las imágenes satélite como fuente independiente de datos de la distribución de una especie para validar la capacidad predictiva de los modelos de distribución potencial de la especie en la actualidad. Además se estudia la sensibilidad de Pinus hartwegii Lindl. frente al cambio climático en el parque nacional Izta-Popo (México) mediante diferentes índices que relacionan los cambios en la superficie actual y futura ocupada por la especie.

Para ello se compararon diferentes modelos de $P$. hartwegii utilizando el algoritmo de modelización de distribución de especies Maxent, con el mapa de vegetación actual obtenido mediante técnicas de teledetección. Los 24 modelos actuales se calibraron para el área de estudio con el $70 \%$ de las presencias divididas al azar y diferentes datos y niveles de complejidad: 2 tipos de presencias de la especie (sólo México y México más Guatemala y Honduras) y 2 grupos con diferentes números de variables ambientales (6 y 7), dos tipos de transformaciones de las variables (Autofeatures y sólo transformaciones lineales, productos y cuadráticas) y 3 diferentes regularizaciones ( 0,1 y 5). Para evaluar los efectos de la complejidad de los modelos de Maxent, se realizó una validación cruzada (no independiente) por medio del estadístico AUC (área bajo la curva ROC) con el 30\% de las presencias no utilizadas en la calibración y el estadístico AICc (criterio de información de Akaike corregido). Los 24 modelos generados fueron posteriormente proyectados al área del parque nacional de Izta-Popo bajo condiciones climáticas actuales. Se realizó una evaluación independiente mediante la correlación de los modelos actuales de $P$. hartwegii con la parte ocupada por el pinar del mapa de vegetación obtenido a partir de la imagen satélite en el parque nacional de Izta-Popo. Por último se proyectó al futuro el modelo que presentaba mejores valores en los estadísticos y con mayor grado de coincidencia con las imágenes satélite y se usaron 4 umbrales diferentes $(0.25,0.5,10$ percentile training presence y maximum test sensitivity plus specificity) para evaluar si la selección del umbral influye en los cálculos de las superficies potenciales de los modelos.

Los resultados obtenidos indican que tanto las presencias usadas en los modelos como la complejidad de los mismos y la elección del umbral de corte a mapas binarios de 
presencia/ausencia afectan a la capacidad predictiva del modelo, así como a la idoneidad predicha por los modelos. Los valores de los índices de ocupación potencial futura y de sensibilidad futura indican que en el parque nacional Izta-Popo, P. hartwegii no se vería perjudicada por el cambio climático.

Palabras clave: Pinus hartwegii, vulnerabilidad, cambio climático, IPCC, Modelos de distribución de especies, imágenes de satélite, proyección, validación, Maxent, teledetección, umbral.

\subsection{INTRODUCCIÓN}

Como respuesta a los incrementos predichos en las temperaturas por el IPCC (2014) debidos al cambio climático, se esperan desplazamientos en las distribuciones de las especies terrestres hacia los polos y hacia altitudes más elevadas (Lenoir y Svenning, 2015). En los ecosistemas de montaña, estos movimientos generalmente se restringen a desplazamientos en altitud, generalmente resultando en pérdida de superficie ocupada por la especie que puede terminar en la desaparición de algunas poblaciones (Colwell et al., 2008 y Dullinger et al., 2012). En estos ecosistemas ya existen indicios de fuertes desplazamientos hacia mayores altitudes tanto de tipos de vegetación como de especies individuales como consecuencia del cambio climático (Morueta-Holme et al., 2015).

Con objeto de evaluar la sensibilidad de la vegetación montañosa frente al cambio climático, entendida como es el grado de afectación de un sistema ecológico por el cambio climático (IPCC, 2007), se pueden estimar los cambios en la distribución de una o varias especies de un ecosistema (Felicísimo et al., 2011). Para estimar las distribuciones potenciales en el presente y futuro y cuantificar las variaciones de la vegetación se usan los modelos de distribución de especies -MDE- (Elith y Leathwick 2009).

Los MDE usan datos de presencia de la especie y de variables ambientales para establecer una relación estadística y encontrar áreas susceptibles de ser idóneas para esa especie (Mateo et al., 2011). Los MDE necesitan datos independientes para ser validados estadísticamente (Araújo et al., 2005). Algunos estudios utilizan datos de independientes para comprobar la capacidad discriminativa de los modelos (Eskildsen et al., 2013), por ejemplo, nuevos datos de observación de diferentes de los datos utilizados para calibrar los modelos (Lobo et al., 2008) mientras que otros comparan los resultados de los modelos con expertos en las distribuciones de las especies (Beck et al., 2014). En este trabajo se plantea el uso de las imágenes de satélite como fuente independiente de datos de la presencia de una especie para 
validar la capacidad predictiva de los modelos de distribución potencial de la especie generados con Maxent en la actualidad. Para ello se compararán los modelos de distribución potencial actual de Pinus hartwegii Lindl. en el parque nacional Izta-Popo (México) con el mapa de vegetación actual obtenido a partir de imágenes de satélite. Además se evaluará el impacto del cambio climático en $P$. hartwegii y el efecto de la selección del umbral de tranformación de mapas de idoneidad en mapas binarios de presencia-ausencia, en los resultados de los modelos proyectados bajo escenarios climáticos futuros. Las previsiones futuras respecto al clima en el parque nacional Izta-Popo (México) señalan subidas progresivas en las temperaturas máximas y mínimas especialmente en los meses estivales y un cambio positivo en el régimen de precipitaciones para el parque (Gaitán et al., 2013). Por tanto, es prioritario evaluar cómo afectará ese cambio en el clima en la vegetación del parque nacional Izta-Popo, especialmente en el cinturón de coníferas que constituye el límite del arbolado en altitud.

\subsection{MATERIAL Y MÉTODOS}

\subsection{1 Área de estudio}

El parque nacional Izta-Popo es un área protegida de México con una superficie de 40,008 hectáreas localizada en la parte centro-oriental del Eje Volcánico Transversal Mexicano. El parque alberga la segunda y tercera cumbre de mayor altitud de México y está situado en el centro de la región más poblada del país, prestando servicios ecosistémicos clave (p.e. el agua) a tres estados de México; Morelos, Puebla y México. El clima en Izta-Popo es templado y se caracteriza por un largo verano lluvioso y fresco. La temperatura media anual es de $14^{\circ} \mathrm{C}$, con $5.4^{\circ} \mathrm{C}$ de la oscilación anual (siendo enero el mes más frío y mayo el mes más cálido con $10.8^{\circ} \mathrm{C}$ y $16.2^{\circ} \mathrm{C}$ de temperatura media, respectivamente). La precipitación anual es de 928 $\mathrm{mm}$, con septiembre como el mes más lluvioso $(185.6 \mathrm{~mm})$ y febrero el mes más seco (6.9 $\mathrm{mm}$ ). En este parque los bosques de coníferas forman la vegetación dominante siendo el límite del arbolado en altitud y constituyendo el reducto más importante de bosques de coníferas y pastizales de alta montaña en México.

El área de estudio considerada para este estudio es la formada por los países que contienen la distribución natural de Pinus hartwegii (Fig. 5.1), es decir México, Guatemala y Honduras (Critchfield y Little, 1966 y Farjon y Filer, 2013). 


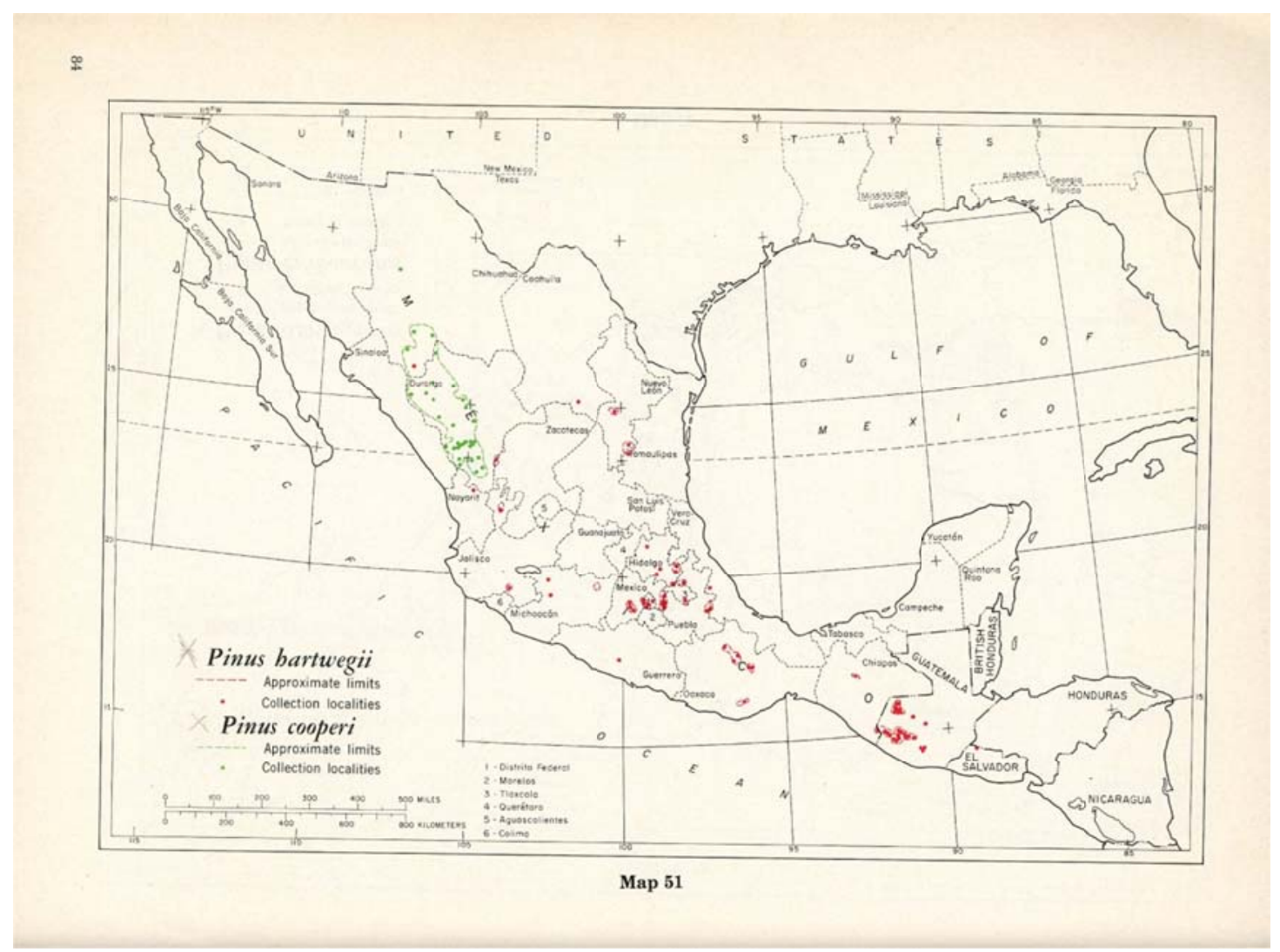

Fig 5.1. En rojo distribución de Pinus hartwegii (Critchfield y Little, 1966).

\subsubsection{Especie de estudio y datos de presencias}

Pinus hartwegii (oocote o pino de las alturas) es una especie con una distribución discontinua (Fig. 5.1) en las cumbres más altas de Honduras y Guatemala, llegando hasta el noreste de México (Farjon, 1996), en zonas con suelos volcánicos y graníticos a menudo pobres en nutrientes (Earle, 2013). Vive entre los $(2,200) 2,500$ y los 4,000(4,300) metros de altitud, a menudo formando masas monoespecíficas (especialmente en México y Guatemala) constituyendo el límite de la vegetación arbórea en altitud (Earle, 2013).

En México y Guatemala, P. hartwegii forma bosques abiertos con sotobosque de herbáceas. En altitudes menos elevadas se mezcla con otras especies como son Pinus montezumae, P. pseudostrobus, P. ayacahuite, Abies religiosa y Cupressus lusitanica, siendo en México donde las masas de P. hartwegii presentan su mayor extensión. En Honduras presenta una extensión limitada en las cumbres de los bosques nublados de montaña, aproximadamente entre 2,700 y 2,850 metros, generalmente con Abies guatemalensis, Cupressus lusitanica, y Quercus (Farjon, 2013).

Climáticamente, además de estar expuesto al estrés hídrico por sufrir un período de sequía, Pinus hartwegii es capaz de resistir variaciones de temperatura de -20 a $38^{\circ} \mathrm{C}\left(11^{\circ} \mathrm{C}\right.$ 
temperatura anual media) y períodos de varios meses con presencia de nieve (Earle, 2013). A pesar de estar etiquetada como de "preocupación menor (LC)" en la Lista roja de especies amenazadas de la UICN (Unión Internacional para la Conservación de la Naturaleza), el crecimiento de esta especie puede verse afectado por las variaciones en las temperaturas y precipitaciones consecuencia del cambio climático ya que se encuentra en el límite superior arbóreo (Farjon, 2013).

De las 143 presencias actuales de la especie (Fig. 5.2), 100 se obtuvieron de las parcelas incluidas en el inventario forestal nacional mexicano (Comisión Nacional Forestal, 2009). Para completar la distribución natural actual de Pinus hartwegii en Guatemala y Honduras, se usó la Distribución de los pinos del mundo (Critchfield y Little, 1966) y el Atlas de coníferas del mundo (Farjon y Filer, 2013). Las presencias del inventario forestal mexicano están basadas en un muestreo de parcelas, tienen mayor precisión en las coordenadas y una mayor uniformidad en la toma de datos que los datos procedentes del Atlas de Coníferas del Mundo (Farjon y Filer, 2013) que están basados en criterio de experto.

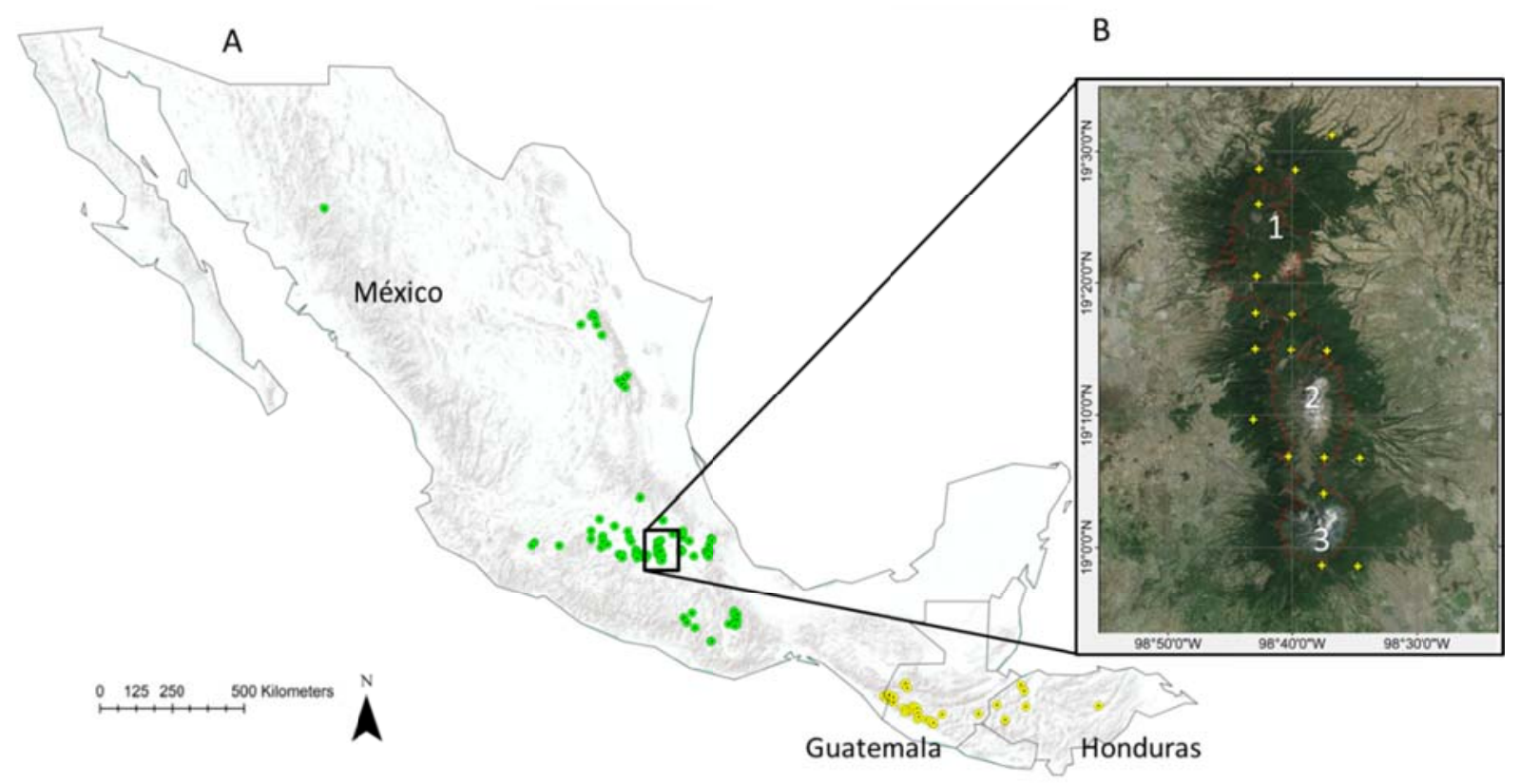

Fig 5.2. Presencias de Pinus hartwegii usadas para generar los modelos. A) Área de distribución natural de $P$. hartwegii: en verde las 100 presencias procedentes del inventario forestal mexicano (Comisión Nacional Forestal, 2009) y en amarillo las 43 procedentes del atlas de coniferas del mundo (Farjon y Filer, 2013). B) Imagen aérea del parque nacional Izta-Popo con sus tres cumbres: 1) Tlalocatépetl (4,120 msnm), 2) Iztaccíhuatl (5,286 msnm) y 3) Popocatépetl (5,500 msnm).

Las 143 presencias (Fig. 5.2) fueron analizadas para eliminar duplicados y outliers debidos a anomalías climáticas o a una mala georreferenciación. En total se eliminaron 13 outliers, 3 de ellos mexicanos que pueden deberse a valores erróneos de la base de datos climática WORLDCLIM (Hijmans et al., 2005) ya que los valores que ofrece WORLDCLIM en ese 
pixel son anómalos comparados con los píxeles de alrededor. Los otros 10 outliers corresponden a presencias en Guatemala y Honduras que pueden ser debidos a una errónea georreferenciación.

Posteriormente se realizó un escalamiento multidimensional no métrico para representar la proximidad climática entre las presencias de los tres países y se observó que las presencias están solapadas en el espacio climático, especialmente las de México y Guatemala (Fig. 5.3), siendo el rango climático de las presencias de 15 a $27^{\circ} \mathrm{C}$ para la temperatura máxima del mes más cálido (Fig. 5.3A) y de 470 a $1900 \mathrm{~mm}$ de precipitación anual (Fig. 5.3B). Aunque como se observa en la Fig. 5.3 las presencias de los tres países del área natural de $P$. hartwegii están agrupadas en el espacio climático, debido a las diferencias en la precisión geográfica de las coordenadas, se consideraron dos tipos de presencias para calibrar los modelos, 1) toda la distribución natural de la especie (121 puntos) y 2) sólo las presencias mexicanas (97 puntos). Los modelos se realizaron con los dos grupos de presencias para valorar la ganancia o pérdida de información climática en el modelo al incluir toda la distribución natural de la especie.
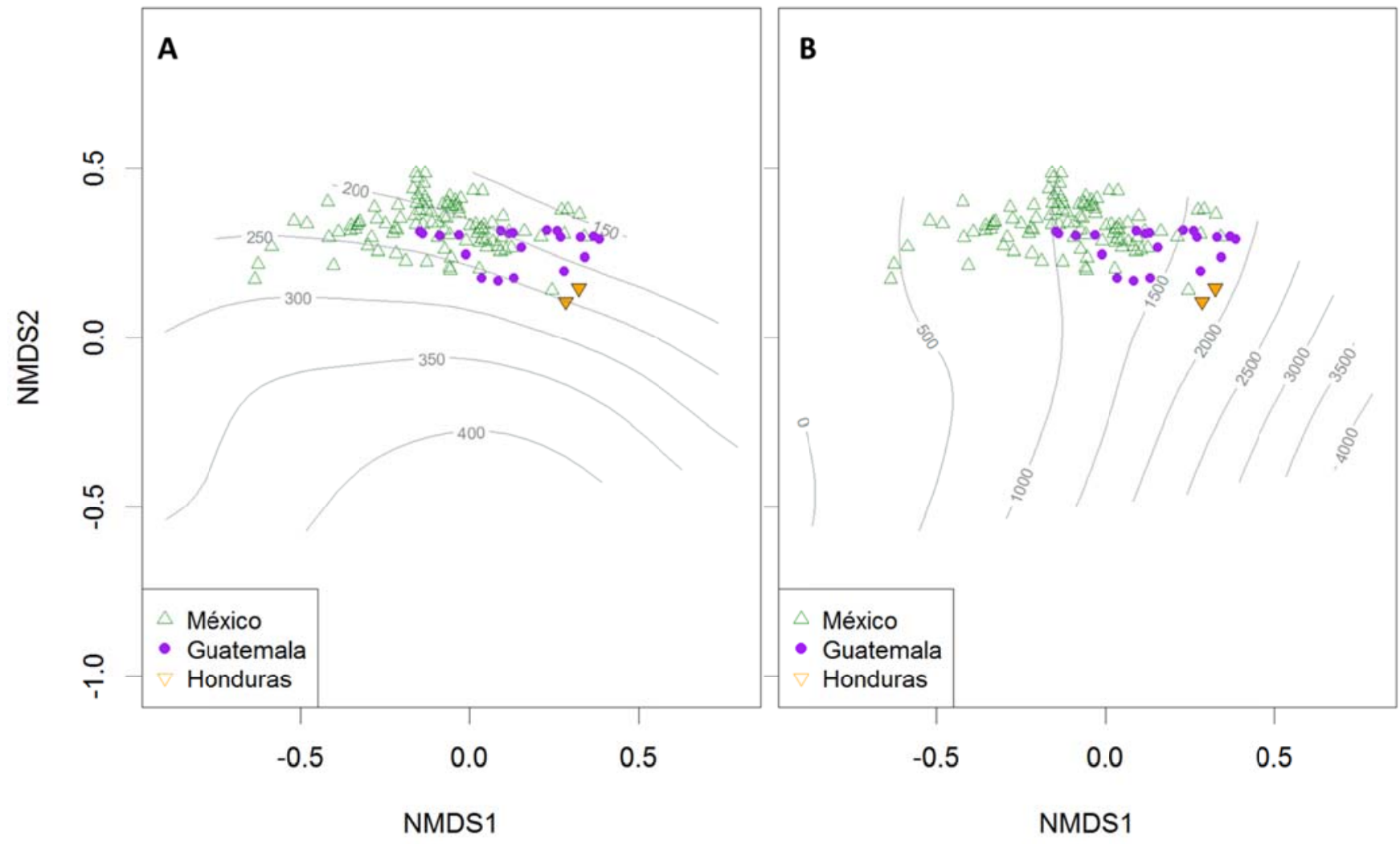

Fig 5.3. Escalamiento multidimensional no métrico (NMDS) para las presencias de Pinus hartwegii en los tres países en los q ue se distribuye actualmente (México, Guatemala y Honduras): A) Las líneas grises representan el gradiente de la temperatur a máxima del mes más cálido (Bio 05) en las presencias (en ${ }^{\circ} \mathrm{C}$ multiplicados por 10) y B) Las líneas grises representan el gra diente de la precipitación anual (Bio 12) en las presencias (en mm). Variables de WORLDCLIM utilizadas en el NMDS: BIO $05,06,08,09,12,15$ y 18 . Stress value $=0.056$. 
El background para representar el espacio ecológico donde la especie habita y que permite la calibración de los modelos (Phillips y Dudík, 2008) fue calculado a partir de 10.000 puntos elegidos al azar en la zona de estudio. Como se usaron dos sets de presencias se generaron dos background: 1) 10.000 puntos al azar en México, Guatemala y Honduras y 2) 10.000 puntos al azar en México.

\subsubsection{Variables ambientales (presente $y$ futuro)}

Los datos de clima para el presente se descargaron de la base de datos WORLDCLIM (http://www.worldclim.org/, Hijmans et al., 2005). Esta base de datos dispone de 19 variables bioclimáticas derivadas de la temperatura y precipitaciones mensuales para el periodo 19502000 a una resolución espacial de $1 \mathrm{~km}$. Estas variables tienen gran sentido biológico como factores limitantes a la hora de explicar la distribución de los organismos, ya que no sólo muestran tendencias mensuales sino que también incluyen tendencias trimestrales importantes para la vegetación (Hijmans et al., 2005). Se eligieron dos set de variables (Tabla 5.1) para generar los modelos teniendo en cuenta la ecología de la especie (criterio de experto) y mediante un análisis de correlación para eliminar variables correlacionadas (correlación de Pearson aceptada $<0.75$ ), y de factor de inflación de varianza (variance inflation factor) para eliminar variables que presentasen multicolinealidad (factor de inflación de varianza aceptado $<5)$.

Tabla 5.1. Variables climáticas (http://www.worldclim.org/, Hijmans et al., 2005) y set de variables usadas para generar los modelos.

\begin{tabular}{|c|c|c|c|}
\hline Código & Descripción & $6 \mathrm{Var}$ & $7 \mathrm{Var}$ \\
\hline BIO 01 & Temperatura media anual & $\mathrm{X}$ & \\
\hline BIO 02 & Rango diurno de temperaturas (media mensual (max temp - min temp)) & & \\
\hline BIO 03 & $\begin{array}{l}\text { Isotermalidad: Relación entre el rango de temperaturas entre el día y la noche y } \\
\text { entre el verano e invierno (BIO02/BIO07) }(* 100)\end{array}$ & & \\
\hline BIO 04 & Estacionalidad en la temperatura (desviación estándar*100) & & \\
\hline BIO 05 & Temperatura máxima del mes más cálido & $\mathrm{X}$ & $\mathrm{X}$ \\
\hline BIO 06 & Temperatura mínima del mes más frío & & $\mathrm{X}$ \\
\hline BIO 07 & Rango de temperatura anual (BIO05-BIO06) & & \\
\hline BIO 08 & Temperatura media del trimestre más húmedo & & $\mathrm{X}$ \\
\hline BIO 09 & Temperatura media del trimestre más seco & $\mathrm{X}$ & $\mathrm{X}$ \\
\hline BIO 10 & Temperatura media del trimestre más cálido & & \\
\hline BIO 11 & Temperatura media del trimestre más frío & & \\
\hline BIO 12 & Precipitación anual & $\mathrm{X}$ & $\mathrm{X}$ \\
\hline BIO 13 & Precipitación del mes más húmedo & & \\
\hline BIO 14 & Precipitación del mes más seco & & \\
\hline BIO 15 & Estacionalidad en la precipitación (Coeficiente de variación) & $\mathrm{X}$ & $\mathrm{X}$ \\
\hline $\mathrm{BIO} 16$ & Precipitación del trimestre más húmedo & & \\
\hline BIO 17 & Precipitación del trimestre más seco & $\mathrm{X}$ & \\
\hline
\end{tabular}




\begin{tabular}{|c|c|c|c|}
\hline BIO 18 & Precipitación del trimestre más cálido & & $\mathrm{X}$ \\
\hline BIO 19 & Precipitación del trimestre más frío & & \\
\hline
\end{tabular}

\subsubsection{Calibración de los modelos (selección de diferentes niveles de complejidad)}

Se generaron 24 modelos para P. hartwegii en el presente calibrados con el $70 \%$ de las presencias divididas al azar y diferentes niveles de complejidad. La selección del nivel apropiado de complejidad en Maxent está relacionada con el número de variables ambientales, las transformaciones permitidas de las variables (llamadas features en Maxent) y el parámetro de regularización ( $\beta$-multiplier) seleccionado en el modelo. Se usaron dos tipos de presencias de la especie (sólo México y México más Guatemala y Honduras) y dos grupos con diferentes números de variables ambientales (6 y 7), dos tipos de transformaciones de las variables (Autofeatures y sólo transformaciones lineales, productos y cuadráticas) y tres regularizaciones diferentes $(0,1$ y 5$)$.

\subsubsection{Evaluación de los modelos actuales}

Para evaluar los efectos de la complejidad de los modelos de Maxent, se realizó una validación cruzada (no independiente) por medio del estadístico AUC (área bajo la curva ROC) con el $30 \%$ de las presencias no utilizadas en la calibración. EL AUC indica la capacidad discriminativa de un modelo (Fielding y Bell, 1997), es decir, la capacidad del modelo de distinguir entre presencias y ausencias. El valor de AUC varía entre 0 y 1 , siendo 0.5 el valor que muestra que el modelo no clasifica los casos mejor que una clasificación al azar. El valor 1 indica que todos los casos se han clasificado correctamente.

También se evaluaron los modelos mediante el estadístico AICc (criterio de información de Akaike corregido), muy usado para la selección de modelos (Warren y Seifert, 2011). Este estadístico establece un equilibrio entre la bondad de ajuste del modelo a los datos y la complejidad (número de parámetros) del modelo (Johnson y Omland, 2004). A igualdad de ajuste a los datos, el AICc penaliza los modelos que tengan mayor complejidad. Los valores de AICc se obtuvieron con el software ENMtools (Warren et al., 2010).

\subsubsection{Validación de los modelos con imágenes de satélite}

En una imagen digital, el territorio observado se divide en una serie de píxeles que constituyen la unidad mínima de información en la imagen. Estos píxeles se clasifican en las diferentes clases de vegetación previamente definidas. Esta clasificación en una u otra clase 
de vegetación se hace utilizando algoritmos de clasificación basados en la reflectividad de cada uno de los pixeles.

Una vez obtenidos los resultados de la clasificación, es necesario verificar estadísticamente los errores en el mapa generado, la validez del producto obtenido y del método empleado mediante el contraste con datos de campo (Chuvieco, 2008 y Congalton y Green, 2008). Para ello se comparan los resultados obtenidos de la clasificación de la imagen de satélite con los datos de referencia (datos reales de muestreo en campo) mediante distintos parámetros estadísticos y una matriz de confusión de forma que se obtienen las discrepancias entre la cubierta terrestre y el mapa que se quiere validar (Moreno y Chuvieco, 2009).

Maria Encina Aulló Maestro, en el marco del proyecto CLIMIFORAD (Impactos Potenciales del Cambio Climático en Ecosistemas Forestales en Cordilleras Latinoamericanas y Herramientas para la Adaptación de la Gestión), elaboró un mapa de vegetación del parque nacional Izta-Popo (Fig. 5.4) a partir de la clasificación la imagen de satélite Landsat 8 de la plataforma GLOVIS (8 de Abril de 2013 - The U.S. Geological Survey Global Visualization Viewer) con el algoritmo de mínima distancia de Mahalanobis (Aulló-Maestro, 2014). Este algoritmo permite tener en cuenta la diferente probabilidad de que se encuentren determinadas cubiertas en la imagen (clases predeterminadas por el usuario) (probabilidad a priori). Permite con ello calcular la probabilidad a posteriori (probabilidad de que se trate de una determinada clase cuando los niveles digitales sean concretos) asumiendo que las covarianzas de las clases son iguales.

La calidad del mapa de vegetación (mapa clasificado) fue evaluada mediante la comprobación de la coincidencia de los resultados obtenidos con la realidad proporcionada por los datos de campo (no utilizados previamente en la obtención de la clasificación) (AullóMaestro, 2014). Esta comparación permite conocer no solo el grado global de acierto, sino también conocer en qué categorías se producen más confusiones, proporcionando información sobre si las clases de vegetación o el método empleado son adecuados. Las medidas del error usadas fueron la matriz de confusión, la fiabilidad global y estadístico Kappa (Congalton, 1991). 


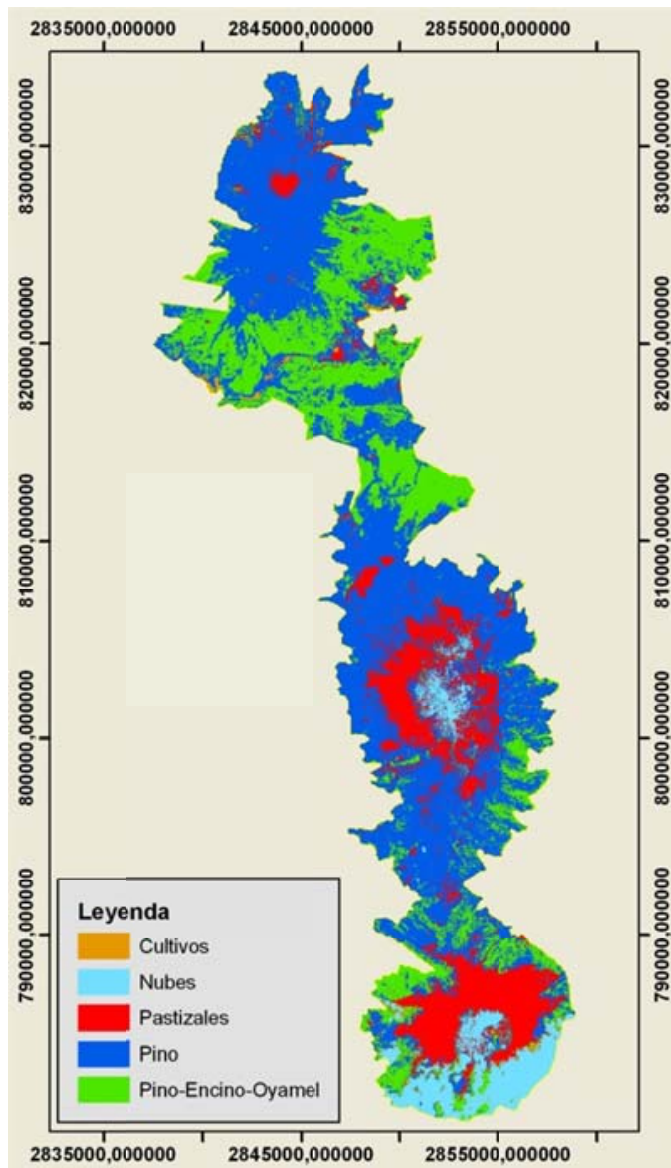

Porcentajes de ocupación:

\begin{tabular}{|c|c|c|}
\hline Clase & $\begin{array}{c}\text { Ocupación } \\
\text { (ha) }\end{array}$ & $\begin{array}{c}\text { Ocupación } \\
\text { (\%) }\end{array}$ \\
\hline Pino & $20.517,46$ & 50,59 \\
\hline Pino-Encino- & $9.499,84$ & 23,42 \\
\hline Pastizales & $8.013,27$ & 19,76 \\
\hline Cultivos & 225,82 & 0,56 \\
\hline Sin información & $2.301,76$ & 5,68 \\
\hline Total & $\mathbf{4 0 . 5 5 8 , 1 5}$ & $\mathbf{1 0 0}$ \\
\hline
\end{tabular}

Coeficientes de validación de la imagen:

\begin{tabular}{|c|c|}
\hline Coeficiente Kappa & $\mathbf{0 , 8 0 8 5}$ \\
\hline Precisión Global & $(8325 / 9753) 85.3584 \%$ \\
\hline
\end{tabular}

Fig. 5.4. Mapa de vegetación, superficies y porcentajes de ocupación de las diferentes clases de vegetación y coeficientes de validación obtenidos a partir de la clasificación de la imagen satélite del Landsat del 8 de Abril de 2013 para el parque nacional Izta-Popo aplicando el algoritmo basado en la mínima Distancia de Mahalanobis (Aulló-Maesttro, 2014). La clase de vegetación que será comparada con los modelos de distribución es la de pinar, que aparece en azul oscuro.

A partir del mapa de vegetación, se extrajo el mapa de vegetación de pinar (Fig. 5.5), que asumimos que coincide con el mapa de distribución de $P$. hartwegii, por ser una masa monospecífica de esta especie, y contactar con otras formaciones vegetales donde $P$. hartwegii queda excluido (Palacio et al., 2000). El mapa de pinar del Izta-Popo se convirtió de vectorial a ráster con el mismo tamaño de pixel que tenía la capa ráster de idoneidad del modelo de pino (0.0083 grados $\sim 1 \mathrm{~km})$ y se calculó la superficie que ocupaba el pinar en cada uno de los pixeles (Fig. 5.6A). Los 24 modelos generados con Maxent fueron proyectados en el área del parque nacional de Izta-Popo bajo condiciones climáticas actuales y se realizó una evaluación independiente con la parte ocupada por el pinar del mapa de vegetación obtenido. 


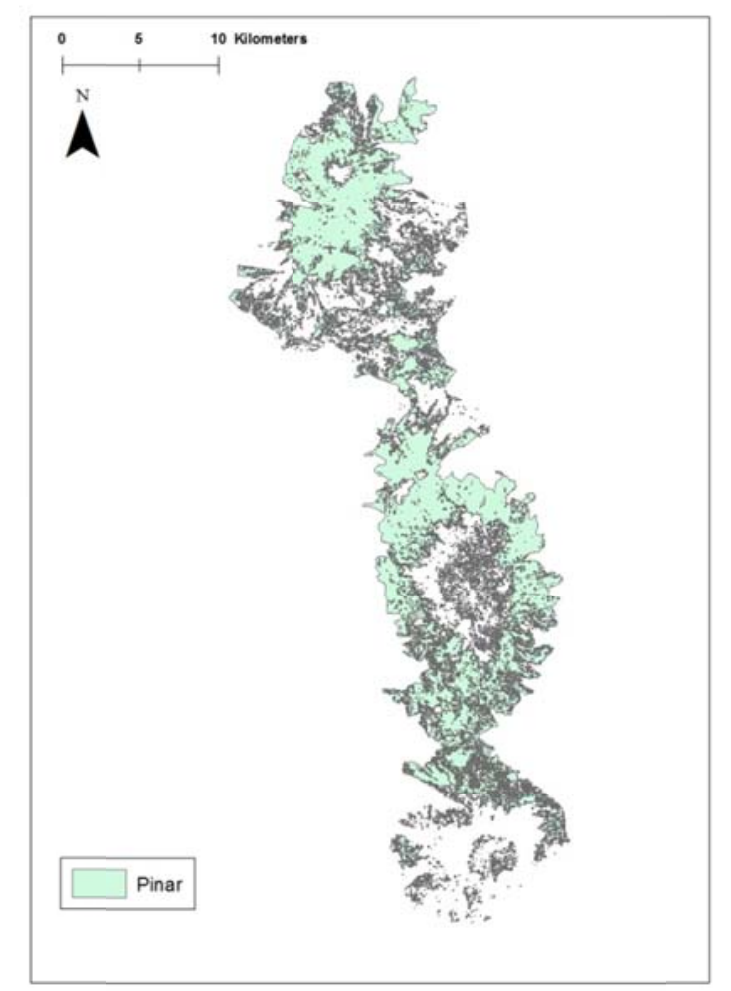

Fig. 5.5. Superficie ocupada por pinar en el parque nacional de Izta-Popo.

La validación se realizó mediante la correlación de la idoneidad del modelo de distribución potencial de $P$. hartwegii para el presente y el área ocupada por el pino para cada pixel de la capa ráster del parque nacional de Izta-Popo. Finalmente se realizó una correlación pixel a pixel entre las dos capas ráster para ver si existía una relación entre la idomeidad de hábitat (del modelo de distribución potencial de $P$. hartwegii en el presente) y el área ocupada por el pinar en cada pixel (del mapa de vegetación). El resultado obtenido con este análisis es un valor de correlación de Pearson entre la capa de superficie de pinar y cada modelo.

\subsubsection{Proyección de los modelos bajo escenarios futuros de cambio climático}

Para evaluar el efecto del cambio climático en las poblaciones de $P$. hartwegii del parque nacional, se proyectaron a futuro los modelos que presentaban mejores valores en los estadísticos AICc, AUC o con mayor grado de coincidencia con las imágenes satélite. Las condiciones climáticas futuras en el área de estudio fueron simuladas utilizando dos modelos de circulación general (Tabla 5.2), los periodos temporales (2050: (2041-2060) y 2070: (2061-2080)) y tres sendas representativas de concentración (RCP: RCP2.6, RCP4.5 y RCP8.5.) del $5^{\circ}$ informe del IPCC (IPCC, 2014). Los datos de clima futuro se obtuvieron de WORLDCLIM (http://www.worldclim.org/cmip5v1) con la misma resolución espacial (1km) y las mismas variables bioclimáticas que las usadas en el presente. 
Tabla 5.2. Modelos de clima usados en el estudio para simular las condiciones climáticas futuras (http://cmippcmdi.llnl.gov/cmip5/).

\begin{tabular}{|c|c|c|c|c|c|}
\hline Modelo & Código & Centro de Investigación & País & $\begin{array}{c}\text { Resolution } \\
\text { espacial } \\
\text { (lon x lat) }\end{array}$ & Referencia \\
\hline $\begin{array}{c}\text { MPI-ESM- } \\
\text { MR }\end{array}$ & MP & $\begin{array}{c}\text { Max Planck Institute for } \\
\text { Meteorology (MPI-M) }\end{array}$ & Alemania & $1.8 \times 1.8^{\circ}$ & $\begin{array}{c}\text { Jungclaus et al., } \\
2013\end{array}$ \\
\hline NorESM1-M & NO & $\begin{array}{c}\text { Norwegian Climate Centre } \\
\text { (NCC) }\end{array}$ & Noruega & $2.5^{\circ} \times 1.9^{\circ}$ & $\begin{array}{c}\text { Iversen et al., } \\
2013\end{array}$ \\
\hline
\end{tabular}

\subsubsection{Evaluación de la sensibilidad de las especies}

La sensibilidad al cambio climático de $P$. hartwegii en el parque Izta-Popo se estudió cualitativamente (evaluando visualmente el cambio de idoneidad de la especie en los modelos proyectados en el parque) y cuantitativamente, calculando el porcentaje de pérdida de superficie idónea de la especie (Felicísimo et al., 2011, Settele et al., 2008 y UICN, 2012).

Para poder calcular diferencias de áreas es necesario convertir los mapas de de idoneidad de la especie (valor continuo de 0 a 1 ) en mapas binarios (valor discreto) con presencia o ausencia de la especie (0/1). Para ello debe elegirse un umbral de idoneidad de la especie (umbral de corte) a partir del cual se considera el hábitat como idóneo o no idóneo para la especie. El establecimiento del umbral es imprescindible para obtener superficies potenciales futuras para el cálculo de sensibilidad futura o de la disminución del área de extensión de presencia de la especie lo cual nos permite el estudio del grado de amenaza siguiendo los criterios de la UICN (UICN, 2012).

En el caso del algoritmo Maxent (Phillips et al., 2006 y Phillips y Dudík, 2008) se puede elegir entre varios umbrales sugeridos por el programa para la especie que además nos indican el error que cometemos al elegir cada umbral. En este estudio se eligieron dos umbrales restrictivos proporcionados por Maxent (i, ii) y dos umbrales fijos (iii, iv): i) "Maximum test sensitivity plus specificity" que trata de maximizar la correcta clasificación simultánea de presencias y ausencias, ii) "10 percentile training presence" es el valor de idoneidad que incluye el $90 \%$ de las presencias dentro del rango potencial de la especie, iii) 0.25 y iv) 0.5 .

Los dos últimos umbrales se seleccionaron para estudiar el efecto de valores de corte elevados en el resultado del modelo ( $\mathrm{Hu}$ and Jiang, 2011), ya que el resto de los umbrales propuestos por Maxent son tan pequeños que predicen la mayor parte, o incluso en algunos casos toda la superficie del parque Izta-Popo, como idónea para la especie. 


\subsubsection{Cálculo y evaluación de los índices de sensibilidad}

Para estudiar la sensibilidad de $P$. hartwegii frente al cambio climático, se calcularon tres superficies diferentes a partir de los mapas binarios (presencia/ausencia) presentes y futuros:

i) SAR: superficie actual real de la especie (superficie real ocupada por la especie en la actualidad).

ii) SPA: superficie potencial actual de la especie (superficie predicha como idónea por el modelo actual).

iii) SPF: superficie potencial futura de la especie (superficie predicha como idónea por el modelo en el futuro).

Una vez obtenidas estas superficies se calcularon los siguientes índices (Felicísimo et al., 2011 y Settele et al., 2008):

$>$ Índice o porcentaje de ocupación del nicho: (SPA-SAR)*100/SPA: Indica el porcentaje del área ocupada por la especie sobre el área total que potencialmente podría ocupar en el territorio según las condiciones climáticas en la actualidad.

$>$ Índice de ocupación potencial futura (porcentaje de pérdida de superficie potencial futura): $\mathbf{I O P F}=(\mathrm{SPA}-\mathrm{SPF}) * 100 / \mathrm{SPA}:$ Indica la relación entre el área que la especie podría potencialmente ocupar en el presente y el área que potencialmente podría ocupar bajo escenarios de cambio climático futuro.

$>$ Índice de sensibilidad futura (porcentaje de pérdida de superficie real futura): ISF $=($ SAR-SPF)*100/SAR: Indica la relación entre el área ocupada por la especie en la actualidad y el área que potencialmente podría ocupar en bajo escenarios de cambio climático futuro.

Los valores de los índices de sensibilidad (índice de ocupación potencial futura -IOPF- e índice de sensibilidad futura -ISF-) son porcentajes de pérdida de superficie de la especie. Por tanto, valores positivos indicarían que la especie es sensible al cambio climático ocupando menos superficie (real o potencial) en el futuro mientras que valores negativos indicarían que la especie presenta una baja sensibilidad al cambio climático, aumentando su superficie en el futuro. 


\subsection{RESULTADOS}

\subsubsection{Modelos de distribución de especie proyectados a presente y validación con imágenes satélite}

Todos los modelos generados en el presente presentan una capacidad predictiva AUC muy elevada, con valores de AUC superiores a 0.98 (Tabla 5.3).

Tabla 5.3. Descripción de los datos usados para generar los modelos y los resultados obtenidos para los estadísticos AUC y AICc. En rojo se muestran los mejores modelos para cada estadístico y en verde el modelo con menor correlación con la imagen aérea.

\begin{tabular}{|c|c|c|c|c|c|c|c|c|c|}
\hline $\begin{array}{l}\text { Código } \\
\text { modelo }\end{array}$ & $\begin{array}{c}\mathbf{N}^{\mathbf{0}} \\
\text { presencias }\end{array}$ & Presencias & Variables & Features & $\begin{array}{c}\beta- \\
\text { multiplier }\end{array}$ & $\mathbf{A U C}$ & AICc & $\begin{array}{c}\mathrm{N}^{\mathrm{o}} \\
\text { parámetros } \\
\text { del modelo }\end{array}$ & $\begin{array}{c}\text { Correlación } \\
\text { idoneidad } \\
\text { modelo- } \\
\text { imagen aérea }\end{array}$ \\
\hline $\begin{array}{c}\text { modelo } \\
1 \\
\end{array}$ & 121 & $\begin{array}{c}\text { México, Guatemala } \\
\text { y Honduras }\end{array}$ & 7var & Autofeatures & 0 & 0.981 & $\mathrm{x}$ & 159 & 0.180 \\
\hline $\begin{array}{c}\text { modelo } \\
2\end{array}$ & 121 & $\begin{array}{c}\text { México, Guatemala } \\
\text { y Honduras }\end{array}$ & 7var & Autofeatures & 1 & 0.986 & 3274.540 & 33 & 0.395 \\
\hline $\begin{array}{c}\text { modelo } \\
3 \\
\end{array}$ & 121 & $\begin{array}{c}\text { México, Guatemala } \\
\text { y Honduras }\end{array}$ & 7var & Autofeatures & 5 & 0.986 & 2908.328 & 14 & 0.403 \\
\hline $\begin{array}{c}\text { modelo } \\
4\end{array}$ & 121 & $\begin{array}{c}\text { México, Guatemala } \\
\text { y Honduras }\end{array}$ & 7var & $\begin{array}{l}\text { Linear, } \\
\text { quadratic y } \\
\text { product }\end{array}$ & 0 & 0.988 & 2846.662 & 12 & 0.443 \\
\hline $\begin{array}{c}\text { modelo } \\
5\end{array}$ & 121 & $\begin{array}{c}\text { México, Guatemala } \\
\text { y Honduras }\end{array}$ & 7var & $\begin{array}{l}\text { Linear, } \\
\text { quadratic y } \\
\text { product }\end{array}$ & 1 & 0.988 & 2839.502 & 10 & 0.446 \\
\hline $\begin{array}{c}\text { modelo } \\
6\end{array}$ & 121 & $\begin{array}{c}\text { México, Guatemala } \\
\text { y Honduras }\end{array}$ & 7 var & $\begin{array}{l}\text { Linear, } \\
\text { quadratic y } \\
\text { product }\end{array}$ & 5 & 0.988 & 2858.539 & 8 & 0.421 \\
\hline $\begin{array}{c}\text { modelo } \\
13\end{array}$ & 121 & $\begin{array}{c}\text { México, Guatemala } \\
\text { y Honduras }\end{array}$ & 6var & Autofeatures & 0 & 0.981 & $\mathrm{x}$ & 140 & 0.233 \\
\hline $\begin{array}{c}\text { modelo } \\
14 \\
\end{array}$ & 121 & $\begin{array}{c}\text { México, Guatemala } \\
\text { y Honduras }\end{array}$ & 6var & Autofeatures & 1 & 0.988 & 2960.424 & 28 & 0.363 \\
\hline $\begin{array}{c}\text { modelo } \\
15\end{array}$ & 121 & $\begin{array}{c}\text { México, Guatemala } \\
\text { y Honduras }\end{array}$ & 6var & Autofeatures & 5 & 0.988 & 2868.965 & 9 & 0.330 \\
\hline $\begin{array}{c}\text { modelo } \\
16\end{array}$ & 121 & $\begin{array}{c}\text { México, Guatemala } \\
\text { y Honduras }\end{array}$ & 6var & $\begin{array}{l}\text { Linear, } \\
\text { quadratic y } \\
\text { product } \\
\end{array}$ & 0 & 0.988 & 2867.293 & 12 & 0.357 \\
\hline $\begin{array}{c}\text { modelo } \\
17\end{array}$ & 121 & $\begin{array}{c}\text { México, Guatemala } \\
\text { y Honduras }\end{array}$ & 6var & $\begin{array}{l}\text { Linear, } \\
\text { quadratic y } \\
\text { product }\end{array}$ & 1 & 0.989 & 2861.545 & 7 & 0.343 \\
\hline $\begin{array}{c}\text { modelo } \\
18\end{array}$ & 121 & $\begin{array}{c}\text { México, Guatemala } \\
\text { y Honduras }\end{array}$ & 6var & $\begin{array}{l}\text { Linear, } \\
\text { quadratic y } \\
\text { product }\end{array}$ & 5 & 0.989 & 2868.027 & 6 & 0.321 \\
\hline $\begin{array}{c}\text { modelo } \\
7 \\
\end{array}$ & 97 & México & 7 var & Autofeatures & 0 & 0.994 & 3071.026 & 79 & 0.340 \\
\hline $\begin{array}{c}\text { modelo } \\
8\end{array}$ & 97 & México & 7 var & Autofeatures & 1 & 0.994 & 2369.420 & 18 & 0.213 \\
\hline $\begin{array}{c}\text { modelo } \\
9\end{array}$ & 97 & México & 7var & Autofeatures & 5 & 0.994 & 2257.977 & 11 & 0.325 \\
\hline $\begin{array}{c}\text { modelo } \\
10\end{array}$ & 97 & México & 7var & $\begin{array}{l}\text { Linear, } \\
\text { quadratic y } \\
\text { product }\end{array}$ & 0 & 0.994 & 2276.604 & 14 & 0.351 \\
\hline $\begin{array}{c}\text { modelo } \\
11\end{array}$ & 97 & México & 7var & $\begin{array}{l}\text { Linear, } \\
\text { quadratic y } \\
\text { product } \\
\end{array}$ & 1 & 0.993 & 2322.880 & 9 & 0.397 \\
\hline $\begin{array}{c}\text { modelo } \\
12\end{array}$ & 97 & México & 7var & $\begin{array}{l}\text { Linear, } \\
\text { quadratic y } \\
\text { product }\end{array}$ & 5 & 0.993 & 2279.900 & 8 & 0.381 \\
\hline
\end{tabular}




\begin{tabular}{|c|c|c|c|c|c|c|c|c|c|}
\hline $\begin{array}{c}\text { modelo } \\
19\end{array}$ & 97 & México & 6 var & Autofeatures & 0 & 0.992 & 2688.568 & 69 & 0.240 \\
\hline $\begin{array}{c}\text { modelo } \\
20\end{array}$ & 97 & México & 6 var & Autofeatures & 1 & 0.992 & 2282.713 & 18 & 0.153 \\
\hline $\begin{array}{c}\text { modelo } \\
21\end{array}$ & 97 & México & 6 var & Autofeatures & 5 & 0.992 & 2279.012 & 8 & 0.225 \\
\hline $\begin{array}{c}\text { modelo } \\
22\end{array}$ & 97 & México & 6 var & $\begin{array}{c}\text { Linear, } \\
\text { quadratic y } \\
\text { product }\end{array}$ & 0 & 0.993 & 2284.948 & 11 & 0.342 \\
\hline $\begin{array}{c}\text { modelo } \\
23\end{array}$ & 97 & México & 6 var & $\begin{array}{c}\text { Linear, } \\
\text { quadratic y } \\
\text { product }\end{array}$ & 1 & 0.992 & 2313.135 & 9 & 0.285 \\
\hline $\begin{array}{c}\text { modelo } \\
24\end{array}$ & 97 & México & 6 var & $\begin{array}{c}\text { Linear, } \\
\text { quadratic y } \\
\text { product }\end{array}$ & 5 & 0.992 & 2333.278 & 5 & 0.265 \\
\hline
\end{tabular}

Los modelos generados con las 97 presencias Mexicanas además de predecir como idónea una mayor superficie geográfica que los generados con las 121 presencias procedentes de México, Guatemala y Honduras, presentan mayores valores de AUC $(0.993 \pm 0.001$ frente a $0.987 \pm 0.003$, respectivamente).

Por otro lado, los modelos seleccionados con el estadístico AICc no coinciden con los seleccionados mediante el AUC. El mejor modelo según el AUC, es decir, el modelo con mayor capacidad predictiva de entre aquellos realizados con toda la distribución de la especie, es el modelo 18 (6 variables, solo usando features lineales, cuadráticas y productos y $\beta$ multiplier $=5$ ). Este modelo es el menos complejo al tener sólo 6 parámetros. En cambio, desde el punto de vista del AICc (estadístico que tiene en cuenta un equilibrio entre la complejidad del modelo y el ajuste del modelo a los datos), el mejor modelo es el modelo 5 (generado con 7 variables, features lineales, cuadráticas y productos y $\beta$-multiplier $=1$ ). Este modelo también tiene un número bajo de parámetros (10).

En el caso de los modelos generados solo con presencias mexicanas, el modelo seleccionado por el AUC es el modelo 8 ( 7 variables, Autofeatures y $\beta$-multiplier $=1)$, mientras que según el AICc el modelo seleccionado es el 9 (7 variables, Autofeatures y $\beta$ multiplier $=5$ ). Estos modelos son más complejos que los modelos generados con las presencias de toda el área natural, con 18 y 11 parámetros respectivamente.

El modelo que mayor correlación presenta entre superficie ocupada por pinar y la idoneidad del hábitat para el pinar es el modelo 5, y el que menor correlación presenta es el modelo 20 (Fig. 5.6 y Tabla 5.3). 


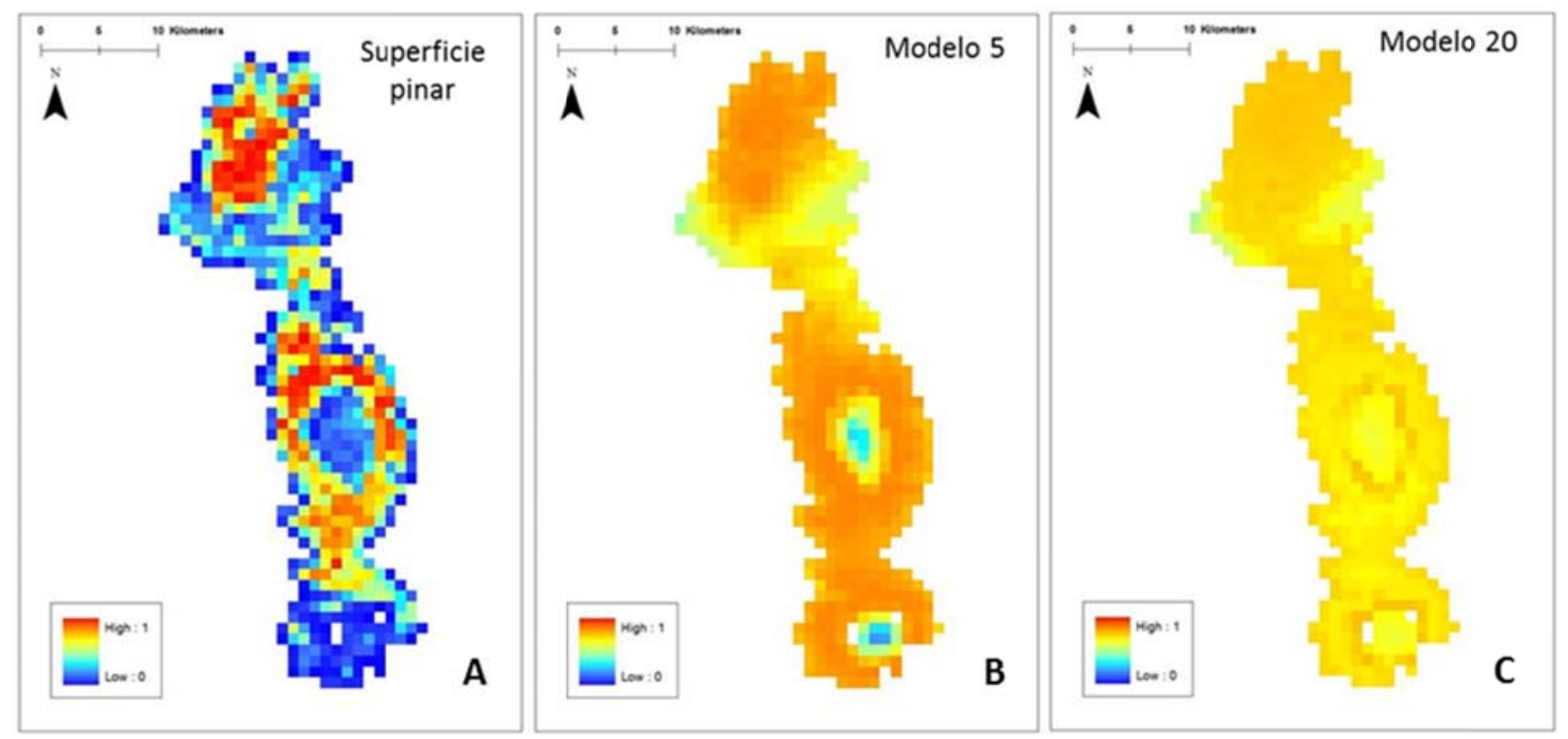

Fig. 5.6. A) Ocupación del pinar en el parque nacional Izta-Popo. El color rojo indica mayor superficie de pinar en el píxel. B) Modelo con mayor correlación (modelo 5) y C) menor correlación (modelo 20) entre superficie de pinar e idoneidad de hábitat para la especie. En B) y C) La idoneidad predicha de la especie se muestra en un gradiente de color: rojo indica alta idoneidad y azul indica poca idoneidad.

\subsubsection{Modelos de distribución de especie proyectados a futuro}

El modelo 5 fue proyectado al área del parque nacional de Izta-Popo bajo condiciones climáticas futuras según los diferentes escenarios de cambio climático (IPCC, 2014).

Como se observa en las Fig. 5.7-5.8, la idoneidad de la especie en la actualidad en IztaPopo es muy elevada (cuanto más rojo, mayor es la idoneidad siendo 1 el valor máximo). Hay que resaltar que para los dos modelos climáticos la idoneidad del parque para Pinus hartwegii aumenta en el año 2050 con respecto a la distribución potencial actual, siendo este aumento de idoneidad más generalizado por todo el parque para la senda de representación 2.6 que para las otras dos sendas. En las otras dos sendas (4.5 y 8.5), la idoneidad aumenta con respecto a la idoneidad en la actualidad pero restringido a las zonas más cercanas a la cumbre, subiendo en altura en el escenario 8.5 respecto al 4.5. Para los dos modelos climáticos se puede observar que para el año 2070, la idoneidad potencial de la especie disminuye drásticamente con respecto a la idoneidad observada en el año 2050, incluso en los píxeles situados fuera del parque Izta-Popo. Esta disminución es menor si se compara con la idoneidad potencial actual pero aun así es observable en las figuras 5.7-5.8 que para los dos modelos climáticos la idoneidad para el año 2070 es menor que la idoneidadl actual, como es de esperar, mucho menor para la senda 8.5 que para la 2.6. En el peor de los escenarios climáticos (RCP 8.5 y año 2070), para los dos modelos climáticos se observa que la distribución proyectada de la especie seguiría manteniéndose en las cumbres, como está en la actualidad (Fig. 5.7-5.8) aunque con una mayor fragmentación. 

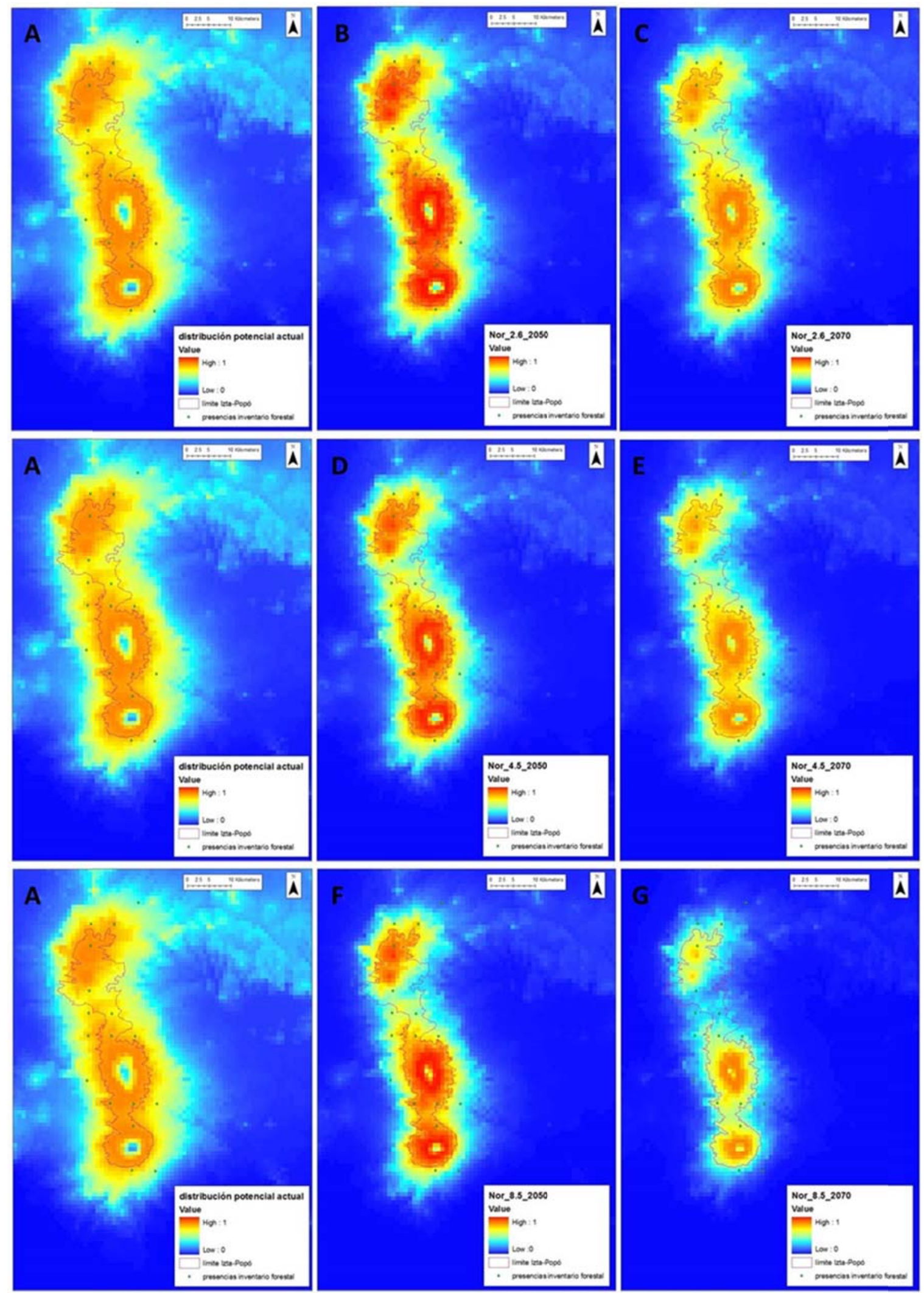

Fig. 5.7. Mapas con la distribución potencial de $P$. hartwegii en el parque nacional Izta-Popo bajo diferentes escenarios climáticos y Sendas Representativas de Concentración del modelo climático NorESM1-M: A) actualidad, B) RCP 2.6 para el año 2050, C) RCP 2.6 para el año 2070, D) RCP 4.5 para el año 2050, E) RCP 4.5 para el año 2070, F) RCP 8.5 para el año 2050 y G) RCP 8.5 para el año 2070. La idoneidad predicha de la especie se muestra en un gradiente de color: rojo indica alta idoneidad y azul indica poca idoneidad. 

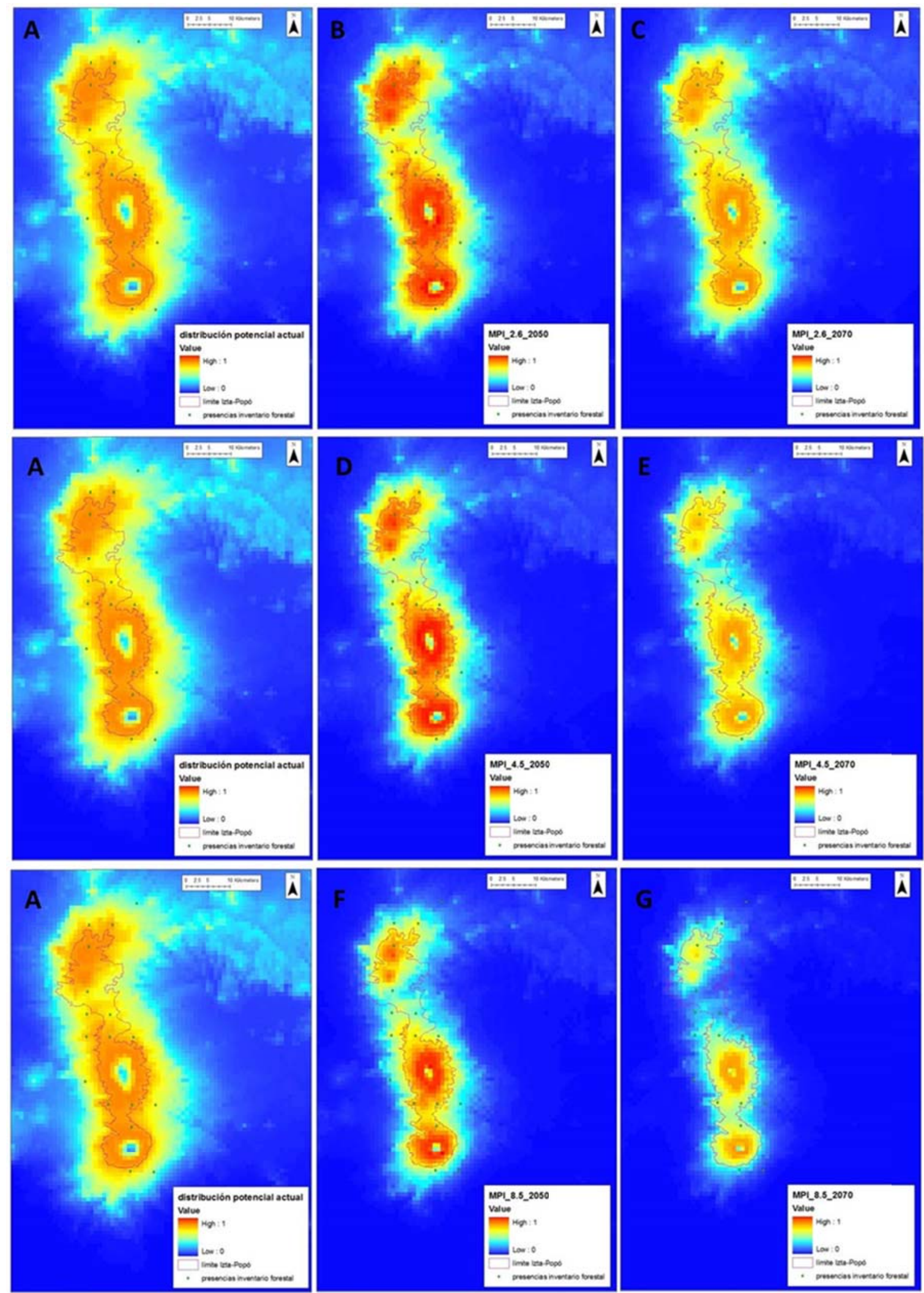

Fig. 5.8. Mapas con la distribución potencial de $P$. hartwegii en el parque nacional Izta-Popo bajo diferentes escenarios climáticos y Sendas Representativas de Concentración del modelo climático MPI-ESM-MR: A) actualidad, B) RCP 2.6 para el año 2050, C) RCP 2.6 para el año 2070, D) RCP 4.5 para el año 2050, E) RCP 4.5 para el año 2070, F) RCP 8.5 para el año 2050 y G) RCP 8.5 para el año 2070. La idoneidad predicha de la especie se muestra en un gradiente de color: rojo indica alta idoneidad y azul indica poca idoneidad. 


\subsubsection{Evaluación de índices de sensibilidad y vulnerabilidad futura}

El índice de ocupación del nicho (Tabla 5.4) indica el grado de equilibrio existente en la actualidad entre la distribución de la especie y el clima del área de estudio. Pinus hartwegii presenta un índice de ocupación de entre 47.81 y 49.28 \% lo que revela que ocupa la mitad de la superficie que podría ocupar en el parque nacional Izta-Popo según el clima actual.

Tabla 5.4. Índice de ocupación del nicho (ION) obtenidos para los diferentes umbrales: 1) 0.25, 2) 0.5, 3) 10 p (10 percentile training presence) y 4) max (Maximum test sensitivity plus specificity).

\begin{tabular}{|c|c|}
\hline Umbral & ION \\
\hline 0.25 & 49.079 \\
\hline 0.5 & 47.814 \\
\hline $10 \mathrm{p}$ & 49.284 \\
\hline $\max$ & 49.284 \\
\hline
\end{tabular}

El índice de ocupación potencial futura (IOPF) indica la variación de la superficie futura idónea respecto a la presente. Como se observa en la tabla 5.5, al usar el umbral más conservador de los sugeridos por Maxent, el "10 percentile training presence", el índice de ocupación potencial futura sale cero, excepto en el 2070 con RCP 8.5 para los dos modelos climáticos. En este caso la superficie proyectada disminuye entre un 2.82\% (según el modelo NorESM1-M) y un 9.4\% (según el modelo MPI-ESM-MR). Los índices de ocupación potencial futura iguales a cero indican que en los modelos proyectados a futuro, la superficie potencial futura sería igual a la superficie potencial actual y por tanto, no se espera un cambio en el área potencial de la especie en el futuro (Tabla 5.5).

Asimismo el umbral más laxo, el "Maximum test sensitivity plus specificity", predice toda la superficie del parque Izta-Popo como idonea tanto para 2050 como para 2070 (Tabla 5.5), para los dos modelos climáticos y todas las sendas de representación. Con lo que de nuevo, la superficie potencial futura sería igual a la superficie potencial actual y no se prevé un cambio en el área potencial de la especie en el futuro.

Con el umbral de 0.25 (Tabla 5.5), en los dos modelos climáticos y periodos temporales (menos en el 4.5 del 2070 en MPI) en las sendas 2.6 y 4.5, el IOPF presenta valores negativos (aunque muy bajos, menores al 1\%) que indicarían ganancia de superficie en el futuro.

Solo con el umbral más restrictivo de 0.5 (en los que el error de omisión es mayor) se aprecian cambios en el índice de ocupación potencial futura (Tabla 5.5). Para la RCP 8.5, se observa que el IOPF es mayor en el año 2070 que en el año 2050 y mayor para el modelo MPI 
que para el modelo Nor. El porcentaje de superficie que la especie dejaría de ocupar en el futuro con respecto a la superficie potencial en el presente sería de $17.2 \%$ en el año 2050 y de $32 \%$ en el año 2070 para el modelo Nor. Mientras que para el modelo MPI es de $23.2 \%$ en el año 2050 y de $43.7 \%$ en el año 2070 (Tabla 5.5).

En cuanto al índice de sensibilidad futura (ISF), como la superficie potencial predicha por los modelos generalmente predice un área con idoneidad elevada para la especie que la que ocupa la especie (porque indica idoneidad climática sin tener en cuenta factores bióticos ni fenómenos de dispersión), este índice nos indicaría la diferencia entre la superficie real actual que la especie ocupa y la que ocuparía en un futuro. Con este índice se pueden valorar rápidamente las variaciones que sufriría la superficie de la especie con el cambio climático. Los valores negativos de este índice obtenidos para todos los escenarios futuros indicarían que Pinus hartwegii aumentaría su superficie en el futuro (Tabla 5.5). El porcentaje de ganancia de la superficie predicha por los modelos varía en función del umbral. Para los umbrales más pequeños ("10 percentile training presence" y "Maximum test sensitivity plus specificity"), el aumento de superficie predicha sería de entre un $78.6 \%$ y un $97.2 \%$ de forma que casi se duplicaría la superficie ocupada por la especie si tenemos en cuenta estos umbrales independientemente del modelo climático, de la senda representativa y del periodo temporal considerado (Tabla 5.5).

Para los umbrales mayores $(0.25$ y 0.5$)$ el aumento de superficie predicha con respecto a la superficie actual ocupada por la especie varía entre un $7.8 \%$ y un $97.2 \%$ de forma que en la senda representativa más agresiva, la RCP 8.5 y el año 2070 es donde se predicen los menores aumentos de superficie de Pinus hartwegii. De forma que para el 2070 y la senda RCP8.5 se predice un aumento del $7.8 \%$ de la superficie para el modelo climático MPI y un aumento del $30.2 \%$ para el modelo Nor (Tabla 5.5). 
Tabla 5.5. Índice de ocupación potencial futura (IOPF) e índice de sensibilidad futura (ISF) obtenidos para los diferentes modelos climáticos, periodos temporales, sendas representativas de concentración y umbrales.

\begin{tabular}{|c|c|c|c|c|c|c|c|c|c|c|c|}
\hline $\begin{array}{c}\text { Modelo } \\
\text { climático }\end{array}$ & $\begin{array}{c}\text { Periodo } \\
\text { temporal }\end{array}$ & RCP & Umbral & IOPF & ISF & $\begin{array}{c}\text { Modelo } \\
\text { climático }\end{array}$ & $\begin{array}{c}\text { Periodo } \\
\text { temporal }\end{array}$ & RCP & Umbral & IOPF & ISF \\
\hline \multirow{12}{*}{ MPI } & \multirow{24}{*}{2050} & \multirow{4}{*}{2.6} & 0.25 & -0.404 & -97.178 & \multirow{12}{*}{ MPI } & \multirow{24}{*}{2070} & \multirow{4}{*}{2.6} & 0.25 & -0.202 & -96.781 \\
\hline & & & 0.5 & 5.945 & -80.231 & & & & 0.5 & 6.359 & -79.438 \\
\hline & & & $10 \mathrm{p}$ & 0.000 & -97.178 & & & & $10 \mathrm{p}$ & 0.000 & -97.178 \\
\hline & & & $\max$ & 0.000 & -97.178 & & & & $\max$ & 0.000 & -97.178 \\
\hline & & \multirow{4}{*}{4.5} & 0.25 & -0.202 & -96.781 & & & \multirow{4}{*}{4.5} & 0.25 & 0.000 & -96.384 \\
\hline & & & 0.5 & 18.663 & -55.860 & & & & 0.5 & 20.319 & -52.686 \\
\hline & & & $10 \mathrm{p}$ & 0.000 & -97.178 & & & & $10 \mathrm{p}$ & 0.000 & -97.178 \\
\hline & & & $\max$ & 0.000 & -97.178 & & & & $\max$ & 0.000 & -97.178 \\
\hline & & \multirow{4}{*}{8.5} & 0.25 & 2.424 & -91.623 & & & \multirow{4}{*}{8.5} & 0.25 & 18.038 & -60.961 \\
\hline & & & 0.5 & 23.188 & -47.189 & & & & 0.5 & 43.744 & -7.799 \\
\hline & & & $10 p$ & \begin{tabular}{|l|}
0.000 \\
\end{tabular} & -97.178 & & & & $10 \mathrm{p}$ & 9.399 & -78.644 \\
\hline & & & $\max$ & 0.000 & -97.178 & & & & $\max$ & 0.000 & -97.178 \\
\hline \multirow{12}{*}{ Nor } & & \multirow{4}{*}{2.6} & 0.25 & -0.404 & -97.178 & \multirow{12}{*}{ Nor } & & \multirow{4}{*}{2.6} & 0.25 & -0.404 & -97.178 \\
\hline & & & 0.5 & 5.945 & -80.231 & & & & 0.5 & 7.187 & -77.851 \\
\hline & & & $10 \mathrm{p}$ & 0.000 & -97.178 & & & & $10 \mathrm{p}$ & 0.000 & -97.178 \\
\hline & & & $\max$ & 0.000 & -97.178 & & & & $\max$ & 0.000 & -97.178 \\
\hline & & \multirow{4}{*}{4.5} & 0.25 & -0.404 & -97.178 & & & \multirow{4}{*}{4.5} & 0.25 & -0.202 & -96.781 \\
\hline & & & 0.5 & 13.753 & -65.269 & & & & 0.5 & 16.622 & -59.771 \\
\hline & & & $10 \mathrm{p}$ & 0.000 & -97.178 & & & & $10 \mathrm{p}$ & 0.000 & -97.178 \\
\hline & & & $\max$ & \begin{tabular}{|l|}
0.000 \\
\end{tabular} & -97.178 & & & & $\max$ & 0.000 & -97.178 \\
\hline & & \multirow{4}{*}{8.5} & 0.25 & 0.000 & -96.384 & & & \multirow{4}{*}{8.5} & 0.25 & 8.225 & -80.231 \\
\hline & & & 0.5 & 17.243 & -58.581 & & & & 0.5 & 32.032 & -30.243 \\
\hline & & & $10 p$ & \begin{tabular}{|l|}
0.000 \\
\end{tabular} & -97.178 & & & & $10 \mathrm{p}$ & 2.817 & -91.623 \\
\hline & & & $\max$ & 0.000 & -97.178 & & & & $\max$ & 0.000 & -97.178 \\
\hline
\end{tabular}

\subsection{DISCUSIÓN}

\subsubsection{Selección de modelos óptimos}

El modelo 5 es el modelo que presenta una mayor correlación entre la imagen aérea y la idoneidad del modelo. Asimismo es el modelo con el mejor balance entre complejidad y bondad de ajuste del modelo a los datos (menor AICc) de los modelos generados con todas las presencias de la especie. Este modelo incorpora toda la información del rango ambiental de la especie ya que fue realizado con todas las presencias de su distribución geográfica, por lo que a priori capta toda variabilidad climática en la que vive la especie y es más apto para proyectar bajo escenarios de cambio climático futuro. No obstante, el AUC es un poco menor al del modelo equivalente realizado solo con presencias mexicanas (modelo 11).

La extensión total de los modelos influye de forma importante en este estadístico (Lobo et al., 2008), de forma que los valores del AUC tienden a ser altos en especies cuya distribución 
geográfica es restringida (pequeña), en relación con el área de estudio descrita por los datos ambientales. Por ello, el AUC obtenido en los modelos generados con las presencias mexicanas es mayor que el realizado con toda la distribución de la especie (incluyendo Honduras y Guatemala).

\subsubsection{Utilidad de las imágenes de satélite en modelos de distribución de especies}

Las imágenes de satélite permiten obtener datos biofísicos de la superficie terrestre y de los ecosistemas como la temperatura del suelo o el índice de vegetación de diferencia normalizada (NDVI) que posibilitan multitud de aplicaciones tales como el estudio de la temperatura superficial del océano, seguimiento de volcanes y la actividad de fuegos forestales y la estimación de cambios en el uso de suelo y en la cobertura vegetal, entre otros (Kerr y Ostrovsky, 2003).

Los trabajos que utilizan imágenes de satélite en modelos de distribución de especies lo hacen para predecir la riqueza de especies de un área o para mejorar los MDE mediante la obtención de variables predictoras (p.e. uso de suelo, productividad, NDVI, variables topográficas) que son incorporadas a los modelos (Cord et al., 2014 y Zimmermann et al., 2007). Sin embargo, las imágenes de satélite no se incorporan en los modelos de distribución de especies como fuente de datos de la especie o para validar los modelos porque estas imágenes generan mapas de tipos forestales, no siendo capaces de distinguir especies a nivel individual (Bradley y Fleishman, 2008). En este caso el piso de pinar corresponde a $P$. hartwegii, con lo que sí es posible asignar la zona de pinar con el modelo de esta especie.

El objetivo de este trabajo era estudiar la viabilidad de la validación de los MDE con imágenes satélite. Como se ha comentado anteriormente, si no se dispone de datos independientes para la validación de los modelos, no se puede saber con certeza qué modelo predice de forma más realista la distribución potencial de la especie en el área de estudio. En este trabajo, los 24 modelos generados para la actualidad presentaban valores de capacidad predictiva (AUC) muy similares pero grandes diferencias en cuanto a la predicción geográfica. Por tanto, la correlación entre la imagen de satélite y los modelos nos permiten seleccionar el modelo 5 como el modelo más similar al mapa de vegetación y por tanto usar este modelo como base para las predicciones futuras. 


\subsection{3 ¿Cómo afectan los umbrales a las predicciones de los modelos?}

El umbral de corte se usa para transformar las predicciones continuas de idoneidad de la especie en valores tipo presencia/ausencia que permiten calcular áreas y cambios en las distribuciones de las especies. La elección del umbral es una decisión importante ya que influye en el resultado del modelo (Nenzén y Araújo, 2011 y Vale et al., 2014) y por ello muchos autores no recomiendan el uso de umbrales para definir la idoneidad de una especie en el futuro (Merow et al., 2013). Este se establece en función del objetivo del estudio y no hay unanimidad en su elección (Nenzén y Araújo, 2011), siendo generalmente establecido minimizando el error de comisión u omisión. El error de comisión o falsos positivos son las ausencias verdaderas predichas por el modelo como presencias que pueden resultar de factores bióticos o abióticos que impiden a la especie ocupar el hábitat idóneo, como son las limitaciones de dispersión y las barreras históricas o por problemas de detección (Miller, 2010). Mientras que el error de omisión o falsos negativos, son las presencias verdaderas predichas por el modelo como ausencias y que pueden resultar de datos o inexactitudes modelo o un umbral demasiado alto. El error de comisión es difícil de calcular ya que para $P$. hartwegii no se dispone de verdaderas ausencias.

En el caso de especies amenazadas o con pocas presencias y en zonas protegidas generalmente se recomienda la elección de umbrales conservadores (menos restrictivos), como el umbral mínimo que recoja todas las presencias, como el "minimum training presence" (Felicísimo et al., 2011 y Vale et al., 2014). Este umbral garantiza que todas las presencias son predichas en áreas idóneas, es decir, predichas como presencias (Aranda y Lobo, 2011). Otros autores (Morueta-Holme et al., 2010) usan umbrales más restrictivos como el de "10th percentile training presence" que predicen como ausencias el 10\% de las presencias con valores más extremos para evitar errores de localización de los puntos, poblaciones no permanentes o condiciones climáticas erróneas en una celda.

Se ha visto que el umbral elegido influye en los resultados, es decir en el valor de los índices futuros. Esto es debido al efecto del umbral en el área potencial predicha como idónea en las proyecciones del modelo en el presente y bajo escenarios de cambio climático. Al evaluar el cambio de la idoneidad cualitativamente se observa que la idoneidad del Izta-Popo para $P$. hartwegii aumenta en el año 2050 con respecto a la distribución potencial actual, disminuyendo de manera importante para el año 2070. En el peor de los escenarios climáticos (RCP 8.5 y año 2070), para los dos modelos climáticos se observa un aumento de la 
fragmentación de la especie al compararse con la distribución actual aunque la distribución proyectada de la especie en el futuro seguiría manteniéndose en las cumbres. Algunos autores desaconsejan el uso de umbrales en el estudio de distribuciones futuras (Merow et al., 2013) porque pueden infra o sobre predecir el área ocupada por una especie en el futuro, como es el caso de $P$. hartwegii. Por ello, se recomienda tomar con precaución los resultados del apartado cuantitativo de este trabajo.

\subsubsection{Efectos del cambio climático en la distribución de Pinus hartwegii en el parque nacional Izta-Popo}

Pese a que hay diversos trabajos que estudian la vulnerabilidad (o sensibilidad) de las especies frente al cambio climático, no hay un consenso en la elección de un indicador que incorpore adecuadamente la sensibilidad futura de una especie (Felicísimo et al., 2011, Settele et al., 2008 y UICN, 2012). Algunos autores utilizan el porcentaje de pérdida de superficie potencial (p.e. Settele et al., 2008) mientras que otros (Felicísimo et al., 2011) utilizan el grado de solapamiento o intersección entre el área actual, área potencial presente y área potencial futura de forma que se penaliza su cambio espacial incluso en los casos en que el área potencial futura aumente. En el caso del parque Izta-Popo, se han generado los índices de sensibilidad a partir del porcentaje de pérdida de superficie potencial y real ya que la extensión espacial del estudio es más local y está centrada en una especie. De forma que se puede hacer un análisis más detallado de la evolución espacial de la distribución de la especie bajo los diferentes escenarios climáticos y valorar gráficamente los posibles desplazamientos del área potencial futura respecto al área actual de la especie.

La idoneidad actual de Pinus hartwegii en el parque es muy alta con la excepción del valle que separa los dos volcanes situados en la zona Norte (Fig. 5.7A). Este valle presenta una idoneidad actual potencial menor, seguramente debido a la menor altitud en esa zona, más favorable a otros tipos de vegetación como el encino (Quercus spp.). Pinus hartwegii actualmente ocupa aproximadamente el 50\% de su nicho climático en el parque (Tabla 5.4). Esta infrautilización del nicho puede deberse a las interacciones bióticas con otras especies, a la dispersión de la especie (Miller, 2010) y a otros factores como la acción antrópica por el aprovechamiento de la madera del pino y el pastoreo.

A pesar de que según la UICN, el cambio climático es la principal amenaza para $P$. hartwegii (Farjon, 2013), los valores obtenidos en este estudio para los índices de ocupación potencial futura y de sensibilidad futura indican que en general, para todos los umbrales y aún 
en los casos de cambio climático más extremo, $P$. hartwegii no se vería perjudicada por el cambio climático en el parque nacional Izta-Popo. Es decir, P. hartwegii tiene una baja sensibilidad (o presenta una alta resiliencia) al cambio climático en el parque nacional IztaPopo, lo que concuerda con otros trabajos que incluyen esta especie (Gómez-Mendoza y Arriaga, 2007). P. hartwegii se vería favorecida por el aumento de temperaturas y precipitaciones que los modelos climáticos predicen para el futuro del parque Izta-Popo (Gaitán et al., 2013) aumentando su área de distribución en el parque, seguramente en detrimento de los pastizales de altura. Sin embargo, otras amenazas no relacionadas con el clima sí podrían afectar a la distribución futura de la especie. Por ejemplo, ya se ha visto cómo ha aumentado la fragmentación de la especie en el parque nacional Izta-Popo entre los años 1993 y 2013 a partir de imágenes satélite como consecuencia de la intervención humana; por el aprovechamiento intensivo de la madera o la pérdida de superficie a favor del pasto para el ganado (Aulló-Maestro et al., 2014).

Pinus hartwegii está catalogado como "preocupación menor (LC)" en la Lista roja de especies amenazadas de la UICN (Unión Internacional para la Conservación de la Naturaleza) en el 2010 (UICN, 2012) debido a la gran área de extensión que presenta, principalmente en zonas de muy elevada altitud (incluso cumbres) donde su explotación se supone que es limitada. Además, está presente en varias áreas protegidas incluyendo parques nacionales como es el caso del parque nacional Izta-Popo. Otras especies mexicanas del género Pinus situadas en cotas altitudinales bajas, a diferencia de P. hartwegii, están menos representadas en áreas protegidas y se encuentran más amenazadas por el cambio climático (Gutiérrez y Duivenvoorden, 2010). 


\section{DISCUSIÓN}

Los principales resultados de esta tesis doctoral indican que los parámetros estudiados: datos de presencia, datos paleobotánicos de las especies y las bases de datos climáticas, la complejidad de los modelos y la selección de los umbrales afectan tanto a la capacidad predictiva como a la idoneidad predicha por los modelos de distribución de especies en diferentes periodos temporales. Como estos modelos son ampliamente usados en estudios que incluyen la transferibilidad espacial o temporal de los modelos sus resultados deben ser interpretados cuidadosamente. En esta tesis se ha demostrado la utilidad de la generación de múltiples modelos con diferentes datos de partida, de la selección de los parámetros de modelización óptimos para cada especie y área de estudio y de la validación de los modelos con datos paleobotánicos e imágenes de satélite para reducir la incertidumbre asociada a estos modelos.

\subsection{INFLUENCIA DE LOS DATOS DE PRESENCIA DE LAS ESPECIES EN LOS MODELOS}

Los MDE se calibran generalmente con todas las presencias naturales de una especie, para recoger la variabilidad ambiental total de la especie (Hijmans y Elith, 2013). Sin embargo esto no es posible cuando se utilizan datos de diversas fuentes, sujetas a errores importantes en cuanto a georreferenciación, taxonomía o sesgos en la calidad de los datos, como es el caso de las especies de los capítulos 3 y 4 . En el capítulo 5 se estudió el efecto de realizar los modelos sólo con las presencias de la especie en México o incorporar todas las presencias naturales de Pinus hartwegii (en México, Honduras y Guatemala), aunque se mezclasen datos de buena calidad (objetivos, sistemáticos y mayor precisión en las coordenadas) como los del inventario mexicano y otros basados en criterio de experto como el Atlas de Coníferas del mundo (Farjon y Filer, 2013). Los modelos con mayor capacidad predictiva fueron los modelos realizados sólo con las presencias mexicanas, pero el modelo que mayor correlación presentaba con el mapa de vegetación realizado al efecto a partir de imágenes de satélite fue un modelo realizado con todas las presencias naturales de la especie.

En el capítulo 4 observamos además que las presencias usadas en los modelos producían diferencias en las predicciones espaciales de la especie, particularmente en los márgenes de la distribución de Pinus uncinata que condujeron a grandes diferencias en los impactos del cambio climático en las poblaciones marginales de la especie. 
Al modelizar la distribución de Pinus uncinata con el sub-hábitat óptimo (aquel con las presencias incluidas en el $80 \%$ del espectro ambiental central de la especie en la Península Ibérica), la distribución potencial de la especie se reduce a los Pirineos, y las presencias marginales (Vinuesa, Gúdar) no se predicen como adecuadas en el presente o en el futuro. Se considera que este sub-hábitat representa el rango ecológico más adecuado para la especie a partir del que se deduce la distribución potencial mínima de una especie en un área (DíazMaroto et al., 2006), pero que no predice adecuadamente las poblaciones marginales, de acuerdo con otros estudios (Fernández et al., 2015). Sin embargo, si se modeliza con la distribución total de la especie incluyendo todas las presencias naturales de la especie, se podría incurrir en errores que conducen a sobre o infra-predecir la distribución potencial de una especie con alta variabilidad genética intra-específica y/o plasticidad fenotípica (BenitoGarzón et al., 2011 y Fernández et al., 2015).

Estos resultados coinciden con otros estudios que obtuvieron diferencias en las predicciones entre la población total y marginal de la especie (Fernández et al., 2015, SoleyGuardia et al., 2016, Vale et al., 2014 y Williams-Tripp et al., 2012), evidenciando que la respuesta de las especies al clima no es uniforme en toda su distribución. Por consiguiente las adaptaciones a las condiciones locales podrían ser muy importantes en la variabilidad de la respuesta al cambio climático (Benito-Garzón et al., 2011).

Por otro lado, si las presencias de una especie se distribuyen de forma desigual entre las diferentes poblaciones, como en el caso de $P$. uncinata donde se dispone de cuatro presencias marginales en un total de 1,121, se observa que debido a su poco peso estadístico, incluso los modelos realizados con el sub-hábitat total de la especie subestiman la idoneidad de estas presencias marginales. Sin embargo se observa que pese a ser ambientalmente marginales, estas ocurrencias de P. uncinata, se encuentran dentro del ambiente adecuado y del nicho reproductivo de la especie (Fig. 4.6, Camarero y Gutiérrez Merino, 1999 y IFN3, 2008). En busca de modelos que representasen mejor estas poblaciones, se trabajó con diferentes subhábitats en función del rango ambiental de la variable en lugar de definir las poblaciones marginales en función de su aislamiento geográfico (Fernández et al., 2015 y Vale et al., 2014) lo que no implica necesariamente distancia ambiental. El sub-hábitat marginal, definido como el que contiene los extremos superior e inferior de la distribución de la especies, predijo valores de idoneidad bajos en las presencias marginales, pero mayores que los predichos por los otros sub-hábitats de la especie. De acuerdo con otros estudios, éste sub-hábitat 
proporciona una mejor estimación de la adaptación de las especies a condiciones fuera del hábitat central (Díaz-Maroto et al., 2006).

\subsection{INFLUENCIA DE LOS DATOS DE CLIMA EN LOS MODELOS}

En los estudios de MDE, y especialmente en los centrados a escala global, la base de datos climática más utilizada es WORLDCLIM. Esto es debido a que dispone de variables climáticas para todo el planeta y con resoluciones espaciales de 30 arc-segundos $\left(\sim 1 \mathrm{~km}^{2}\right)$ para el presente, pasado y futuro (Hijmans et al., 2005). Sin embargo, dado que esta base de datos solo incorpora las estaciones meteorológicas de información gratuita, en algunas regiones la cobertura espacial y altitudinal de WORLDCLIM es bastante escasa (p.e. España). La comparación de WORLDCLIM con bases de datos regionales como el atlas climático digital de la Península Ibérica (Ninyerola et al., 2005) ha puesto de manifiesto la pobre representación en WORLDCLIM de algunos fenómenos climáticos a escala local (Bedia et al., 2013).

En la España peninsular, por ejemplo, WORLDCLIM dispone de datos de 142 estaciones meteorológicas y no presenta estaciones por encima de los 1,888 msnm de altitud (Fig. 4.2). La base de datos de la AEMET (Agencia Estatal de Meteorología), usada en el capítulo 4 de esta tesis dispone, en cambio, de 1,830 estaciones para la temperatura y de 5,053 para la precipitación cubriendo altitudinalmente hasta los 2,500 msnm. Entre las dos bases de datos existen grandes diferencias en los datos actuales (basados en datos observados), por ejemplo, de hasta $4^{\circ} \mathrm{C}$ en la temperatura máxima del mes más cálido y de $600 \mathrm{~mm}$ en la precipitación anual de las presencias de Pinus uncinata (Tabla 4.2). A su vez, las predicciones de idoneidad en el presente y en el futuro difieren, siendo WORLDCLIM más optimista en las predicciones futuras de Pinus uncinata. Las bases de datos globales no han sido evaluadas rigurosamente a nivel regional/local. Por tanto sus predicciones a futuro deben ser interpretadas cuidadosamente ya que pueden presentar problemas de extrapolación (Bedia et al., 2013). Esto es especialmente importante en la evaluación de impactos de cambio climático en zonas montañosas (p.e. $P$. uncinata puede llegar a los 2,700 $\mathrm{msnm}$ ), donde la cobertura en altitud de estaciones de las bases de datos globales es deficiente (WORLDCLIM sólo alcanza hasta los $1,888 \mathrm{msnm})$.

\subsection{LOS DATOS PALEOBOTÁNICOS EN LA VALIDACIÓN DE LOS MODELOS}

La mayoría de los artículos revisados en el capítulo 2 se centran en el uso del polen, utilizado generalmente para validar cuantitativamente los modelos proyectados en el pasado 
que han sido calibrados en el presente (p.e. De Lima et al., 2014 y Record et al., 2013). Esto es debido a la mayor abundancia de datos polínicos y su disponibilidad para los períodos de tiempo seleccionados correspondientes a las simulaciones climáticas de los modelos de circulación global (6,000 y 21,000 años BP). Sin embargo, la interpretación del polen fósil tiene algunas limitaciones como son: i) el polen recogido en los registros polínicos pueden proceder de un gran área de territorial y, por lo tanto, la información recogida debe ser considerada a nivel regional; ii) la representatividad de los diferentes taxones se ve condicionada por las diferencias en la producción de polen y su dispersión, iii) la morfología del polen permite su identificación normalmente de la familia o género pero rara vez a nivel de especie. Además, iv) los diagramas polínicos deben contar con cronologías muy precisas, disponiendo de un buen control de las edades calibradas y de modelos de edad-profundidad fiables, lo que no es habitual.

Para transformar los porcentajes de polen de los registros polínicos en presencia/ausencia pasada de las especies, generalmente se define un umbral polínico para la especie objeto de estudio (Alba-Sánchez et al., 2010). Algunos autores utilizan el mismo umbral para todas las especies (Maiorano et al., 2013) mientras que otros utilizan más de uno para cada especie (Record et al., 2013). Aunque generalmente los autores especifican el umbral usado en el estudio, no hay consenso en el uso del umbral adecuado para cada especie (p.e. $0.01 \%$ y 0.02\% para Abies alba y Picea abies en Pearman et al. (2008); 1\% para Abies en AlbaSánchez et al. (2010); 1\% para Abies alba, Picea abies y Fagus sylvatica en Maiorano et al. (2013); 0.5\% y 1\% para Fagus en Record et al. (2013)).

Como ejemplo del uso de datos paleobotánicos, en el capítulo 3 se validaron con datos de polen fósil los modelos calibrados en el presente y proyectados al pasado (Holoceno medio) en la Península Ibérica. Esto se realizó con dos especies adecuadas para realizar la validación paleobotánica (Alnus glutinosa y Corylus avellana), al ser géneros monoespecíficos en el territorio que cuentan con muchos datos en los registros fósiles disponibles en la Península. Los modelos proyectados al pasado fueron validados de dos formas complementarias. La primera fue mediante la selección de un umbral para cada especie, y la segunda correlacionando la idoneidad de la especie en el pasado con las abundancias de polen (el porcentaje sin transformar a presencia-ausencia). Estas dos validaciones paleobotánicas independientes presentaron la misma tendencia en los resultados. Por tanto en este caso la selección de umbral no introdujo sesgo en el estudio, pese a la falta de acuerdo en la selección 
del umbral para estimar la presencia local de una especie a partir del porcentaje de polen (Lisitsyna et al., 2011).

\subsection{LAS IMÁGENES DE SATÉLITE EN LA VALIDACIÓN DE LOS MODELOS}

Los resultados del capítulo 5 demuestran que la validación de los MDE con imágenes de satélite es viable. Ante la falta de datos independientes en el presente o en el pasado para validar los modelos, las imágenes de satélite constituyen una fuente de datos alternativa para seleccionar los modelos y parámetros óptimos para predecir la distribución de la especie.

En este estudio de caso, como el piso de pinar en el mapa de vegetación corresponde a $P$. hartwegii, es posible realizar la correlación entre mapa de vegetación con el modelo actual de esta especie en el área de estudio, lo que no es habitual ya que las imágenes de satélite generan mapas de tipos forestales o de vegetación, sin que suelan distinguir entre especies a nivel individual (Bradley y Fleishman, 2008).

\subsection{INFLUENCIA DE LA COMPLEJIDAD DE LOS MODELOS}

Los resultados de los capítulos 3, 4 y 5 confirman que la complejidad de los modelos es un factor importante que afecta a la capacidad predictiva del modelo, a la idoneidad predicha y a su transferibilidad temporal, como ha sido demostrado por otros autores (Syfert et al., $2013 \mathrm{y}$ Warren et al., 2014). Incluso cuando los modelos complejos muestran una gran capacidad predictiva al predecir distribuciones actuales, pueden producir predicciones pobres en áreas o periodos de tiempo diferentes (Warren et al., 2014). La mala transferencia de los modelos muy complejos en el tiempo y el espacio puede ser consecuencia de no capturar correctamente el nicho de la especie por el excesivo ajuste de los modelos a los datos de calibración (Warren et al., 2014).

Al estudiar el efecto de la complejidad en el tiempo en el capítulo 3 encontramos que en la predicción actual de los modelos, la capacidad predictiva aumenta al incrementar la complejidad del modelo para Alnus glutinosa y Corylus avellana. Esta tendencia no se observa en los modelos proyectados en el Holoceno medio. Los modelos de complejidad intermedia (los modelos seleccionados según el AICc), presentaban mejor transferibilidad temporal que los modelos más complejos (los modelos seleccionados según el AUC) ya que su capacidad predictiva en las predicciones del Holoceno medio era más alta que las de los modelos más complejos. 
Estos resultados coinciden con los de Warren et al. (2014) que observaron que la complejidad del modelo afectaba a la amplitud de nicho y a la idoneidad predicha de la especie bajo escenarios de cambio climático. Al ser los MDE muy utilizados para identificar áreas adecuadas para albergar especies en el futuro (Araújo et al., 2011) se advierte que los modelos muy complejos calibrados en condiciones climáticas actuales pueden sobreestimar la reducción de la idoneidad ambiental en el futuro.

\subsection{SELECCIÓN DE LOS PARÁMETROS ÓPTIMOS DE COMPLEJIDAD EN MAXENT}

En los tres capítulos de esta tesis en los que se estudia la complejidad de los modelos (Capítulos 3, 4 y 5) los resultados coinciden en que los modelos generados con los parámetros predeterminados de Maxent eran más complejos (con mayor número de parámetros) que los modelos óptimos seleccionados. Los modelos óptimos fueron seleccionados con el estadístico AICc que permite un equilibrio entre el ajuste del modelo a los datos y la complejidad del modelo, frente al AUC que generalmente seleccionaba los modelos más complejos. En los tres capítulos las features (o transformaciones de las variables) utilizadas eran las mismas o un menor número que las predeterminadas por Maxent. En los tres capítulos el $\beta$-multiplier siempre era mayor que el valor por defecto de Maxent ( $\beta$-multiplier=1), en consonancia con otros estudios (Anderson y González, 2011, Muscarella et al., 2014, Radosavljevic y Anderson, 2014 y Shcheglovitova y Anderson, 2013).

Por tanto, nuestros resultados junto con otros estudios (Cao et al., 2013, Halvorsen et al., 2015, Muscarella et al., 2014 y Warren et al., 2014) demuestran que es importante encontrar los parámetros de complejidad que proporcionen los modelos óptimos para predecir la distribución de una especie en el tiempo y en el espacio.

\subsection{INFLUENCIA DE LA SELECCIÓN DEL UMBRAL DE LOS MODELOS}

En esta tesis se demuestra cómo la elección del umbral de corte (que transforma la variable continua de idoneidad en variable binaria presencia/ausencia) influye en el resultado del modelo, como ha sido constatado por otros autores (Nenzén y Araújo, 2011 y Vale et al., 2014). Incluso algunos autores como Merow et al. (2013) no recomiendan el uso de umbrales por la variabilidad en los resultados de la idoneidad futura predicha para la especie. No obstante, el uso de umbrales es imprescindible para obtener una predicción binaria que nos permita calcular superficies e índices de supervivencia o sensibilidad de la especie frente al cambio climático (Felicísimo et al., 2011). 
En general, el umbral se debe elegir en función del objetivo del estudio (Nenzén y Araújo, 2011). Por ejemplo, si se va a estudiar una especie en peligro o con muy pocos datos de presencia, se puede elegir el umbral de idoneidad que consiga que todas las presencias reales sean predichas como presencias (p.e. "minimum training presence"; Aranda y Lobo, 2011) o en cambio, el "10th percentile training presence" que deja fuera de las presencias predichas al $10 \%$ de las presencias observadas cuyos valores de valores de idoneidad son más bajos. En el caso de Pinus hartwegii se ha observado que los umbrales obtenidos por Maxent tienen valores de corte de idoneidad muy bajos y predicen como idónea gran parte de la distribución de la especie en el Izta-Popo en el presente. En el futuro los umbrales de "10 percentile training presence" y "maximum test sensitivity plus specificity" producen los mismos resultados en los índices de ocupación futura. Sólo aplicando los umbrales fijos de 0.25 y 0.5 se observan cambios en los índices de sensibilidad.

Para reducir el efecto de la selección del umbral en los modelos se pueden seleccionar varios umbrales y evaluar las diferencias entre resultados o no aplicar umbrales y estudiar los cambios visuales en la predicción futura de la especie. Ambas perspectivas se han aplicado en el capítulo 5 de esta tesis con resultados similares, que $P$. hartwegii no se verá afectada por el cambio climático. 


\section{CONCLUSIONES}

1. Esta tesis pone de manifiesto la valiosa información que los datos paleobotánicos proporcionan para, además de conocer la vegetación del pasado, calibrar y evaluar las proyecciones de los modelos de distribución de especies en el pasado.

2. Se destaca la importancia de al incorporar los datos paleobotánicos en los modelos de distribución de especies, tener un control adecuado de los datos en cuanto a la representatividad de las especies, taxonomía, distribución espacial y su control cronológico ya que estas cuestiones afectan a las conclusiones de los estudios de modelización de especies.

3. Para controlar las incertidumbres asociadas a la introducción de los datos paleobotánicos en los modelos de distribución de especies, cuantificar la robustez de los resultados y mejorar la reproducibilidad de los análisis, se recomienda buscar un equilibrio entre la cantidad de datos utilizados y su calidad. Además se recomienda a los autores que usan datos paleobotánicos en los modelos de distribución de especies que detallen los procedimientos y decisiones tomadas en los aspectos previamente mencionados (representatividad de especies, táxones elegidos para el estudio, control cronológico en las secuencias polínicas y características de los datos) en la metodología de sus estudios.

4. La inclusión de macrofósiles en los estudios de paleomodelización mejoran la resolución taxonómica, espacial y cronológica de los análisis paleoecológicos aunque estos datos sólo están disponibles para algunos taxones y en determinadas regiones y periodos temporales.

5. Los resultados confirman que la complejidad de los modelos afecta de forma importante a la capacidad predictiva de los mismos, especialmente al proyectarlos en diferentes periodos temporales. En los MDE actuales la capacidad predictiva del modelo aumenta al aumentar su complejidad para las dos especies, no así en los modelos proyectados en el Holoceno medio. Los valores óptimos para predecir la distribución actual y pasada se encuentran en modelos con una complejidad intermedia.

6. Se recomienda seleccionar los parámetros de complejidad de los modelos que mejor funcionen para cada estudio y especie ya que los parámetros seleccionados por defecto por 
Maxent generan modelos de complejidad elevada que tienen menor capacidad predictiva en las proyecciones temporales.

7. Para predecir la distribución de una especie en el tiempo, se recomienda usar datos paleobotánicos para validar los modelos. Al ser estos datos escasos, se recomienda el uso de modelos más simples, con una complejidad intermedia (número de variables y $\beta$-multiplier intermedio y el uso de la opción autofeatures en Maxent), para optimizar la transferibilidad temporal de los modelos.

8. En esta tesis se muestra cómo las distintas bases de datos de clima y modelos de circulación general producen diferencias en los modelos en cuanto a idoneidad predicha y en el área predicha como idónea. Por consiguiente, se recomienda el uso de bases de datos regionales con buena cobertura espacial y altitudinal de estaciones meteorológicas y de varios modelos de circulación general para tener en cuenta la posible variación de los resultados debida a los datos climáticos.

9. Las poblaciones marginales con muy pocos datos de presencia en comparación con la poblacion principal (core) no aparecen reflejadas en los modelos generados con la presencia total de la especie. Los modelos generados con las presencias de la especie divididas en subhábitats presentan diferencias importantes en las predicciones geográficas. De esta forma, los modelos generados con los sub-hábitats sirven como complemento al modelo realizado con las presencias totales de la especie para obtener una mejor comprensión de la distribución potencial actual y futura de la especie.

10. El modelo del sub-hábitat marginal realizado con los dos extremos de la distribución ambiental de la especie predice como idónea la distribución principal (core) de la especie. Por tanto, ante recursos limitados para muestrear la distribución de una especie es más útil dirigir un mayor esfuerzo de muestreo en los extremos ambientales de la especie que en la población central.

11. En este trabajo se ejemplifica cómo las imágenes de satélite constituyen una fuente alternativa de datos para la validación de la capacidad predictiva actual de los MDE con clases de vegetación monoespecíficas. 
12. Esta tesis demuestra que la elección del umbral de corte en la idoneidad predicha para la especie influye en el área predicha como idónea por el modelo, en el presente y en el futuro. Por ello, se recomienda el uso de varios umbrales según el objetivo del estudio y así incorporar la sensibilidad de los resultados frente a la elección del umbral.

13. Se observa que Pinus hartwegii presenta una idoneidad actual muy alta en el parque nacional Izta-Popo, aunque sólo ocupa la mitad de su nicho climático actual.

14. Pinus hartwegii presenta una baja sensibilidad al cambio climático, de modo que podría verse favorecida por el aumento de temperaturas esperado para el parque nacional Izta-Popo, aumentando su área de distribución en el parque. 


\section{CONCLUSIONS}

1. This thesis demonstrates the valuable information provided by the palaeobotanical data not only to know the past occurrence of species but also to calibrate and evaluate the predictions of palaeo-species distribution models.

2. When incorporating palaeobotanical data into species distribution models, it is important to control the adequacy of the data in terms of species representativity, taxonomy, spatial distribution and chronological control as these aspects might compromise the conclusions of SDM studies.

3. To control the data uncertainties associated to the use of palaeobotanical data in SDM studies, quantify the robustness of the results and improve the repeatability of the analyses, it is recommended to seek a balance between quality and quantity in the data used. In addition, authors that couple palaeobotanical data and SDM are encouraged to detail the procedures and decisions taken in each of the stages mentioned (species representativity, study taxa, chronological control in the pollen records and data characteristics) in the corresponding material and methods section of their publications.

4. The addition of macrofossils in the palaeo-SDMs improves the taxonomic, spatial and chronological resolution of paleoecological analysis although this data is only available for some taxa and in certain regions and time periods.

5. The results confirm that model complexity significantly affects model performance, especially when projected to different time periods. Model performance increased with model complexity when predicting current distributions for both species, but not in models projected to mid-Holocene climatic conditions. Models of intermediate complexity resulted in the best trade-off to predict species distributions across time.

6. We highly recommend conducting species-specific model tuning to find the best modeling settings to control for complexity since Maxent default settings can generate over-complex models which perform more poorly over time. 
7. To predict the distribution of a species in time, it is recommended to use palaeobotanical data to validate the models. Since these data are scarce, we recommend selecting simpler models, with an intermediate complexity (intermediate number of variables and intermediate $\beta$-multiplier coupled with autofeatures option selected in Maxent) in order to optimize the temporal transferability of the models.

8. This thesis shows how different climate databases and general circulation models produce differences in the models results in terms of predicted suitability and area predicted as suitable. Therefore we recommend the use of regional databases with good spatial and altitudinal coverage of meteorological stations and several general circulation models to take into account the possible variation of results due to climatic data.

9. Marginal populations with very few presence data compared to the core population are not represented in the models developed with the total presence of the species. Models generated with the species presences divided in sub-habitats present large differences in the geographic predictions. Models generated with the sub-habitats serve as a complement to the model performed exclusively with the total presences of the species and help obtaining a better understanding of the present and future potential distribution of the species.

10. The marginal sub-habitat model performed with the two environmental tails of the species distribution predicts the species core distribution as suitable. Therefore, given limited resources for species sampling, it is more useful to focus greater sampling effort on the environmental extremes of the species than on the core population.

11. This thesis exemplifies how satellite imagery are an alternative source of data for the validation of the model performance of the SDM in monospecific vegetation classes.

12. This thesis proves that the threshold choice influences the area predicted as suitable by the model in the present and in the future. Therefore, it is recommended using several thresholds according to the study objective to incorporate the sensitivity of the results to the choice of the threshold.

13. It is noticed that Pinus hartwegii presents a high current suitability in the Izta-Popo national park although it only occupies half of its current climatic niche. 
14. Pinus hartwegii shows low sensitivity to climate change, being favored by the temperatures increase estimated for the Izta-Popo national park, increasing its distribution area in the park. 


\section{REFERENCIAS}

Alba-Sánchez, F., López-Sáez, J.A., Pando, B.B., Linares, J.C., Nieto-Lugilde, D., LópezMerino, L., 2010. Past and present potential distribution of the Iberian Abies species: a phytogeographic approach using fossil pollen data and species distribution models. Divers. Distrib. 16, 214-228.

Alsos, I.G., Alm, T., Normand, S., Brochmann, C., 2009. Past and future range shifts and loss of diversity in dwarf willow (Salix herbacea L.) inferred from genetics, fossils and modelling. Glob. Ecol. Biogeogr. 18, 223-239.

Anderson, P.M., Barnosky, C.W., Bartlein, P.J., Behling, P.J., Brubaker, L., Cushing, E.J., Dodson, J., Dworetsky, B., Guetter, P.J., Harrison, S.P., et al., 1988. Climatic changes of the last 18,000 years: observations and model simulations. Science. 241, 1043-1052.

Anderson, R.P., Gonzalez Jr., I., 2011. Species-specific tuning increases robustness to sampling bias in models of species distributions: an implementation with Maxent. Ecol. Model. 222, 2796-2811.

Anderson, R.P., Martínez-Meyer, E., 2004. Modeling species' geographic distributions for preliminary conservation assessments: An implementation with the spiny pocket mice (Heteromys) of Ecuador. Biol. Conserv. 116, 167-179.

Aranda, S.C., Lobo, J.M., 2011. How well does presence-only-based species distribution modelling predict assemblage diversity? A case study of the Tenerife flora. Ecography. $34,31-38$.

Araújo, M.B., Alagador, D., Cabeza, M., Nogués-Bravo, D., Thuiller, W., 2011. Climate change threatens European conservation areas. Ecol. Lett. 14, 484-92.

Araújo, M.B., Lobo, J.M., Moreno, J.C., 2007. The Effectiveness of Iberian Protected Areas in Conserving Terrestrial Biodiversity. Conserv. Biol. 21, 1423-1432.

Araújo, M.B., Pearson, R.G., 2005. Equilibrium of species' distributions with climate. Ecography. 28, 693-695. 
Araújo, M., Pearson, R., Thuiller, W., Erhard, M., 2005. Validation of species-climate impact models under climate change. Glob. Change Biol. 11, 1504-1513.

Araújo, M.B., Peterson, A.T., 2012. Uses and misuses of bioclimatic envelope modeling. Ecology. 93, 1527-1539.

Arribas, P., Abellán, P., Velasco, J., Biton, D.T., Lobo, J.M., Millán, A., Sánchez-Fernández, D., 2012. La vulnerabilidad de las especies frente al cambio climático, un reto urgente para la conservación de la biodiversidad. Ecosistemas 21, 79.84.

Aulló-Maestro, M.E., 2014. Elaboración de un mapa de vegetación a partir de la clasificación supervisada de imágenes de satélite sobre dos territorios de interés para el Proyecto CLIMIFORAD, Parque Nacional Izta-Popo Zoquiapan (México) y Bosque Modelo Comuna de Panguipulli (Chile). (Documento técnico sin publicar).

Austin, M., 2007. Species distribution models and ecological theory: a critical assessment and some possible new approaches. Ecol. Model. 200, 1-19.

Autio, J., Hicks, S., 2004. Annual variations in pollen deposition and meteorological conditions on the fell Aakenustunturi in northern Finland: potential for using fossil pollen as a climate proxy. Grana. 43, 31-47.

Baker, A.G., Zimny, M., Keczynski, A., Bhagwat, S.A., Willis, K.J., Latałowa, M., 2016. Pollen productivity estimates from old-growth forest strongly differ from those obtained in cultural landscapes: Evidence from the Bia owieza National Park, Poland. Holocene. 26, 80-93.

Banks, W.E., d'Errico, F., Peterson, A.T., Vanhaeren, M., Kageyama, M., Sepulchre, P., Ramstein, G., Jost, A., Lunt, D., 2008. Human ecological niches and ranges during the LGM in Europe derived from an application of eco-cultural niche modeling. J. Archaeol. Sci. 35, 481-491.

Bartlein, P.J., Edwards, M.E., Shafer, S.L., Barker, E.D., 1995. Calibration of radiocarbon ages and the interpretation of paleoenvironmental records. Quat. Res. 44, 417-424.

Beck, J., Böller, M., Erhardt, A., Schwanghart, W., 2014. Spatial bias in the GBIF database and its effect on modeling species' geographic distributions. Ecol. Inform. 19, 10-15. 
Bedia, J., Herrera, S., Gutiérrez, J.M., 2013. Dangers of using global bioclimatic datasets for ecological niche modeling. Limitations for future climate projections. Glob. Planet. Change. 107, 1-12.

Behrensmeyer, A.K., Kidwell, S.M., Gastaldo, R.A., 2000. Taphonomy and paleobiology. Paleobiology. 26, 103-147.

Benito, B.M., Cayuela, L., Albuquerque, F.S., 2013. The impact of modelling choices in the predictive performance of richness maps derived from species-distribution models: guidelines to build better diversity models. Methods Ecol. Evol. 4, 327-335.

Benito, B., Lorite, J., Peñas, J., 2011. Simulating potential effects of climatic warming on altitudinal patterns of key species in Mediterranean-alpine ecosystems. Clim. Chang. $108,471-483$.

Benito, B.M., Svenning, J.C., Kellberg-Nielsen, T., Riede, F., Gil-Romera, G., Mailund, T., Kjaergaard, P.C., Sandel, B.S., 2016. The ecological niche and distribution of Neanderthals during the Last Interglacial. J. Biogeogr.

Benito-Garzón, M., Alía, R., Robson, T.M., Zavala, M.A., 2011. Intra-specific variability and plasticity influence potential tree species distributions under climate change. Glob. Ecol. Biogeogr. 20, 766-778.

Benito-Garzón, M., Sánchez de Dios, R., Sáinz Ollero, H., 2007. Predictive modelling of tree species distributions on the Iberian Peninsula during the Last Glacial Maximum and Mid-Holocene. Ecography. 30, 120-134.

Benito-Garzón, M., Sánchez de Dios, R., Sáinz Ollero, H., 2008. The evolution of the Pinus sylvestris L. area in the Iberian Peninsula from the last glacial maximum to 2100 under climate change. Holocene. 18, 705-714.

Bennett, K.D., Willis, K.J., 2001. Pollen, in Smol, J.P., Birks, H.J.B., Last, W.M., (Eds.) Tracking environmental change using lake sediments. Volume 3: Terrestrial, Algal and Siliceous Indicators. Kluwer Academic Publishers. The Netherlands. pp. 5-32.

Beug, H.J., 2004. Leitfaden der Pollenbestimmung für Mitteleuropa und angrenzende Gebiete. Pfeil, München. 
Bhatt, S., Gething, P.W., Brady, O.J., Messina, J.P., Farlow, A.W., Moyes, C.L., Drake, J.M., Brownstein, J.S., Hoen, A.G., Sankoh,O., et al., 2013. The global distribution and burden of dengue. Nature. 496, 504-507.

Birks, H., Birks, H.J.B., 2000. Future uses of pollen analysis must include plant macrofossils. J. Biogeogr. 27, 31-35.

Blaauw, M., 2010. Methods and code for 'classical' age-modelling of radiocarbon sequences. Quat. Geochronol. 5, 512-518.

Blaauw, M., Heegaard, E., 2012. Estimation of age-depth relationships. In Birks, H.J.B., et al., (Eds). Tracking environmental change using lake sediments. Springer Netherlands. pp. 379-413.

Blanco, A., Rubio, A., Sánchez, O., Elena, R., Gómez, V., Graña, D., 2000. Autoecology of chestnut (Castanea sativa Miller) in Galicia (Spain). Forest Syst. 1, 337-62.

Blois, J.L., Williams, J.W.J., Grimm, E.C., Jackson, S.T., Graham, R.W., 2011. A methodological framework for assessing and reducing temporal uncertainty in paleovegetation mapping from late-Quaternary pollen records. Quat. Sci. Rev. 30, 19261939.

Bradley, B.A., Fleishman, E., 2008. Can remote sensing of land cover improve species distribution modelling?. J. Biogeogr. 35, 1158-1159.

Brewer, S., 2002. Recolonisation postglaciaire de quelques taxons tempérés en Europe: une approche spatiale et temporelle. PhD Thesis. Institut Méditerranéen d'Ecologie et de Paléoécologie, Marseille, France.

Brewer, S., Jackson, S.T., Williams, J.W., 2012. Paleoecoinformatics: applying geohistorical data to ecological questions. Trends Ecol. Evol. 27, 104-112.

Bronk Ramsey, C., 2009. Bayesian Analysis of Radiocarbon Dates. Radiocarbon. 51, 337360.

Broström, A., Nielsen, A.B., Gaillard, M.J., Hjelle, K., Mazier, F., Binney, H., Bunting, J., Fyfe, R., Meltsov, V., Poska, A., et al., 2008. Pollen productivity estimates of key 
European plant taxa for quantitative reconstruction of past vegetation: a review. Veg. Hist. Archaeobot. 17, 461-478.

Brown, K.S., 1987. Areas where humid tropical forest probably persisted. In Whitmore, T.C., Prance, G.T., (Eds). Biogeography and Quaternary history in tropical America. Clarendon Press, Oxford. pp. 44-45.

Brown, J.H., 1995. Macroecology. University of Chicago Press, Chicago.

Buisson, L., Thuiller, W., Casajus, N., Lek, S., Grenouillet, G., 2010. Uncertainty in ensemble forecasting of species distribution. Glob. Chang. Biol. 16, 1145-1157.

Businsky, R., 1999. Taxonomicka studie agregatu Pinus mugo a jeho hybridnich populaci. (Taxonomic essay in the Pinus mugo complex and its hybrid populations). Acta Pruhoniciana, 68, pp.123-143.

Cao, Y., DeWalt, R.E., Robinson, J.L., Tweddale, T., Hinz, L., Pessino, M., 2013. Using Maxent to model the historic distributions of stonefly species in Illinois streams: The effects of regularization and threshold selections. Ecol. Model. 259, 30-39.

Camarero, J.J., Gutiérrez Merino, E., 2008. La respuesta del crecimiento de "Pinus uncinata" al clima en poblaciones relictas del sistema ibérico. Zubía. 20, 61-96.

Camarero, J.J., Gutiérrez Merino, E., 1999. Estructura, patrón espacial y regeneración de una población de Pinus uncinata Ram. en su límite occidental de distribución (Castillo de Vinuesa, Soria-La Rioja). Zubía. 17, 99-153.

Carnaval, A.C., Moritz, C., 2008. Historical climate modelling predicts patterns of current biodiversity in the Brazilian Atlantic forest. J. Biogeogr. 35, 1187-1201.

Carrión, J.S. (Coord), 2013. Paleoflora ibérica: Plioceno-Cuaternario. Ministerio de Economía y Competitividad, Madrid. Universidad de Murcia y Fundación Séneca, Murcia. ISBN: 978-84-615-9026-1.

Castroviejo, S. (Coord) 1986-2016. Flora ibérica 1-8, 10-15, 17-18, 21. Real Jardín Botánico, CSIC, Madrid. 
Ceballos, L., 1966. Mapa Forestal de España. Escala 1:400.000. Ministerio de Agricultura. Dirección General de Montes, Caza y Pesca Fluvial, Madrid.

Christensen, K.I., 1987. Taxonomic revision of the Pinus mugo complex and P.× rhaetica (P. mugo $\times$ sylvestris) (Pinaceae). Nord. J. Bot.. 7, 383-408.

Chuvieco, E., 1996 Fundamentos de teledetección espacial. Ediciones Rialp.

Chuvieco, E. 2008. Teledetección Ambiental. La observación de la Tierra desde el Espacio. Editorial Ariel Ciencia. 527 pp.

CMNUCC, 1992. Convención Marco de las Naciones Unidas sobre Cambio Climático. Naciones Unidas.

Collevatti, R.G., Terribile, L.C., de Oliveira, G., Lima-Ribeiro, M.S., Nabout, J.C., Rangel, T.F., Diniz-Filho, J.A.F., 2013. Drawbacks to palaeodistribution modelling: the case of South American seasonally dry forests. J. Biogeogr. 40, 345-358.

Colwell, R.K., Brehm, G., Cardelús, C.L., Gilman, A.C., Longino, J.T., 2008. Global warming, elevational range shifts, and lowland biotic attrition in the wet tropics. Science. $322,258-261$.

Comisión Nacional Forestal, 2009. El Inventario Nacional Forestal y de Suelos de México 2004-2009. Una herramienta que da certeza a la planeación, evaluación y el desarrollo forestal de México. Zapopan, Jalisco, México.

Conedera, M., Tinner, W., Crameri, S., Torriani, D., Herold, A., 2006. Taxon-related pollen source areas for lake basins in the southern Alps: an empirical approach. Veg. Hist. Archaeobot. 15, 263-272.

Congalton, R.G., 1991. A Review of Assessing the Accuracy of Classifications of Remotely Sensed Data. Remote Sens. Environ. 37, 35-46.

Congalton, R.G., Green, K., 2008. Assessing the accuracy of remotely sensed data: principles and practices. CRC press. 
Cord, A.F., Klein, D., Gernandt, D.S., la Rosa, J.A.P., Dech, S., 2014. Remote sensing data can improve predictions of species richness by stacked species distribution models: a case study for Mexican pines. J. Biogeogr. 41, 736-748.

Costa, M., Morla, C., Sainz, H. (Eds.) 1997. Los bosques ibéricos. Una interpretación geobotánica. Planeta, Barcelona.

Critchfield, W.B., Little, E.L., 1966. Geographic distribution of the pines of the world (Vol. 991). US Department of Agriculture, Forest Service.

Davis, M.B., 1967. Pollen accumulation rates at Rogers Lake, Connecticut, during late-and postglacial time. Rev. Palaeobot. Palynol. 2, 219-230.

Davis, M.B., Deevey, E.S., 1964. Pollen accumulation rates: estimates from late-glacial sediment of Rogers Lake. Science. 145, 1293-1295.

De Lima, N.E., Lima-Ribeiro, M.S., Tinoco, C.F., Terribile, L.C., Collevatti, R.G., 2014. Phylogeography and ecological niche modelling, coupled with the fossil pollen record, unravel the demographic history of a Neotropical swamp palm through the Quaternary. J. Biogeogr. 41, 673-686.

Desprat, S., Díaz Fernández, P.M., Coulon, T., Ezzat, L., Pessarossi-Langlois, J., Gil, L., Morales-Molino, C., Sánchez Goñi, M.F., 2015. Pinus nigra (European black pine) as the dominant species of the last glacial pinewoods in south-western to central Iberia: a morphological study of modern and fossil pollen. J. Biogeogr. 42, 1998-2009.

Diaz-Maroto, I.J., Vila-Lameiro, P., Díaz-Maroto, M.C., 2006. Autecology of sessile oak (Quercus petraea) in the north-west Iberian Peninsula. Scand. J. For. Res. 21, 458-469.

Do Amaral Franco, J., 1986. Pinus L. En: Castroviejo, S. et al. (Eds.) Flora Iberica vol. I: 168-174. CSIC, Real Jardín Botánico de Madrid, Madrid.

Dormann, C.F., Purschke, O., Márquez, J.R.G., Lautenbach, S., Schröder, B., 2008. Components of uncertainty in species distribution analysis: a case study of the great grey shrike. Ecology. 89, 3371-3386. 
Dullinger, S., Gattringer, A., Thuiller, W., Moser, D., Zimmermann, N.E., Guisan, A., Willner, W., Plutzar, C., Leitner, M., Mang, T., et al., 2012. Extinction debt of highmountain plants under twenty-first-century climate change. Nat. Clim. Chang. 2, 619622.

Dyke, A.S., 2005. Late Quaternary vegetation history of northern North America based on pollen, macrofossil, and faunal remains. Géographie Phys. Quat. 59, 211-262.

Dzialuk, A., Muchewicz, E., Boratyński, A., Montserrat, J.M., Boratyńska, K., Burczyk, J., 2009. Genetic variation of Pinus uncinata (Pinaceae) in the Pyrenees determined with cpSSR markers. Plant Syst. Evol. 277, 197-205.

Earle, C.J., 2013. The Gymnosperm Database. URL: http://www.conifers.org

Eeley, H.A., Lawes, M.J., Piper, S.E., 1999. The influence of climate change on the distribution of indigenous forest in KwaZulu-Natal, South Africa. J. Biogeogr. 26, 595617.

Elith, J., Graham, C.H., 2009. Do they? How do they? WHY do they differ? On finding reasons for differing performances of species distribution models. Ecography. 32, 66-77.

Elith, J., Graham, C.H., Anderson, R.P., Dudík, M., Ferrier, S., Guisan, A., Hijmans, R.J., Huettmann, F., Leathwick, J.R., Lehmann, A., et al., 2006. Novel methods improve prediction of species' distributions from occurrence data. Ecography. 29, 129-151.

Elith, J., Kearney, M., Phillips, S., 2010. The art of modelling range-shifting species. Methods Ecol. Evol. 1, 330-342.

Elith, J., Leathwick, J.R., 2009. Species Distribution Models: Ecological Explanation and Prediction Across Space and Time. Annu. Rev. Ecol. Evol. Syst. 40, 677-697.

Elith, J., Phillips, S.J., Hastie, T., Dudík, M., Chee, Y.E., Yates ,C.J., 2011. A statistical explanation of MaxEnt for ecologists. Divers. Distrib. 17,43-57.

Erdtman, G., Sarjeant, W.A.S., Praglowski, J., Nilsson, S., Dunbar, A., 1969. Handbook of palynology: morphology, taxonomy, ecology: an introduction to the study of pollen grains and spores. Copenhagen: Munksgaard. $486 \mathrm{pp}$. 
Eskildsen, A., Le Roux, P.C., Heikkinen, R.K., Høye, T.T., Kissling, W.D., Pöyry, J., Wisz, M.S., Luoto, M., 2013. Testing species distribution models across space and time: high latitude butterflies and recent warming. Glob. Ecol. Biogeogr. 22, 1293-1303.

Espíndola, A., Pellissier, L., Maiorano, L., Hordijk, W., Guisan, A., Alvarez, N., 2012. Predicting present and future intra-specific genetic structure through niche hindcasting across 24 millennia. Ecol. Lett. 15, 649-657.

European pollen Database.URL: http://www.europeanpollendatabase.net/ [accessed 23 January 2012]

Farjon, A., 1996. Biodiversity of Pinus (Pinaceae) in Mexico: speciation and palaeoendemism. Bot. J. Linn. Soc. 121, 365-384.

Farjon, A., 2013. Pinus hartwegii. The IUCN Red List of Threatened Species 2013: e.T42367A2975679. Accessed on 28 July 2015.

Farjon, A., Filer, D., 2013. An atlas of the world's conifers: an analysis of their distribution, biogeography, diversity and conservation status. Brill.

Fægri, K., Iversen, J., 1950. Textbook of Modern Pollen Analysis. - Ejnar Munksgaard. Copenhagen. 168 pp.

Felicísimo Á.M. (Coord.) 2011. Impactos, vulnerabilidad y adaptación al cambio climático de la biodiversidad española. 2. Flora y vegetación. Oficina Española de Cambio Climático, Ministerio de Medio Ambiente y Medio Rural y Marino. Madrid. 552 pp.

Fernández, P., Jordano, D., Haeger, J.F., 2015. Living on the edge in species distribution models: The unexpected presence of three species of butterflies in a protected area in southern Spain. Ecol. Model. 312, 335-346.

Ficetola, G.F., Thuiller, W., Miaud, C., 2007. Prediction and validation of the potential global distribution of a problematic alien invasive species - the American bullfrog. Divers. Distrib. 13, 476-485.

Fielding, A.H., Bell, J.F., 1997. A review of methods for the assessment of prediction errors in conservation presence/absence models. Environ. Conserv. 24, 38-49. 
Franklin, J., 2010. Mapping species distribution: spatial inference and prediction. Cambridge University Press, Cambridge.

Franklin, J., Potts, A.J., Fisher, E.C., Cowling, R.M., Marean, C.W., 2015. Paleodistribution modeling in archaeology and paleoanthropology. Quat. Sci. Rev. 110, 1-14.

Franklin, J., Wejnert, K.E., Hathaway, S.A., Rochester, C.J., Fisher, R.N., 2009. Effect of species rarity on the accuracy of species distribution models for reptiles and amphibians in southern California. Divers. Distrib. 15, 167-177.

Gaines, S.D., Denny, M.W., 1993. The largest, smallest, highest, lowest, longest, and shortest: extremes in ecology. Ecology. 74, 1677-1692.

Gaitán, E., Torres, L., Monjo, R., Pórtoles, J., 2013. Generación de escenarios regionales de Cambio Climático para zonas forestales Latinoamericanas mediante downscaling estadístico de modelos asociados al CMIP5. (Documento técnico sin publicar).

Gajewski, K., 2008. The Global Pollen Database in biogeographical and palaeoclimatic studies. Prog. Phys. Geogr. 32, 379-402.

Gallien, L., Douzet, R., Pratte, S., Zimmermann, N.E., Thuiller, W., 2012. Invasive species distribution models-how violating the equilibrium assumption can create new insights. Glob. Ecol. Biogeogr. 21, 1126-1136.

García-Amorena, I., Manzaneque, F.G., Rubiales, J.M., Granja, H.M., de Carvalho, G. S., Morla, C., 2007. The Late Quaternary coastal forests of western Iberia: A study of their macroremains. Palaeogeogr. Palaeoclimatol. Palaeoecol. 254, 448-461.

García-Amorena, I., Morla, C., Rubiales, J.M., Manzaneque, F.G., 2008. Taxonomic composition of the Holocene forests of the northern coast of Spain, as determined from their macroremains. Holocene. 18, 819-829.

Gaston, K.J., 2003. The structure and dynamics of geographic ranges. Oxford Univ. Press.

Giesecke, T., Fontana, S.L., 2008. Revisiting pollen accumulation rates from Swedish lake sediments. Holocene. 18, 293-305. 
Giesecke, T., Hickler, T., Kunkel, T., Sykes, M.T., Bradshaw, R.H., 2007. Towards an understanding of the Holocene distribution of Fagus sylvatica L. J. Biogeogr. 34, 118131.

Giesecke, T., Davis, B., Brewer, S., Finsinger, W., Wolters, S., Blaauw, M., de Beaulieu, J.L., Binney, H., Fyfe, R.M., Gaillard, M.J., Gil-Romera, G. 2014. Towards mapping the late Quaternary vegetation change of Europe. Veg. Hist. Archaeobot. 23, 75-86.

Gliemeroth, A.K., 1995. Paläoökokologische Untersuchungen über die letzten 22000 Jahre in Europa: Vegetation, Biomasse und Einwanderungsgeschichte der wichtigsten Waldbäume. Gustav Fischer, Stuttgart.

Global Biodiversity Information Facility. URL: http://www.gbif.org [accessed 23 January 2012]

Global Pollen Database. URL: https:/www.ncdc.noaa.gov/paleo/gpd.html [accessed 15 September 2014]

Gómez-Mendoza, L., Arriaga, L., 2007. Modeling the effect of climate change on the distribution of oak and pine species of Mexico. Conserv. Biol. 21, 1545-1555.

Goring, S., Lacourse, T., Pellatt, M.G., Mathewes, R.W., 2013. Pollen assemblage richness does not reflect regional plant species richness: a cautionary tale. J. Ecol. 101, 11371145 .

Goring, S., Dawson, A., Simpson, G.L., Ram, K., Graham, R.W., Grimm, E.C., Williams, J.W., 2015. Neotoma: A Programmatic Interface to the Neotoma Paleoecological Database. Open Quat. 1, 1-17.

GRASS Development Team, 2012. Geographic Resources Analysis Support System (GRASS) Software. Open Source Geospatial Foundation Project. URL: http://grass.osgeo.org [accessed 5 March 2012]

Graham, C.H., Elith, J., Hijmans, R.J., Guisan, A., Townsend Peterson, A., Loiselle, B.A., 2008. The influence of spatial errors in species occurrence data used in distribution models. J. Appl. Ecol. 45, 239-247. 
Graham, C.H., Loiselle, B.A., Velásquez-Tibatá, J., Cuesta Camacho, F., 2012. Modelos de distribución de especies y el desafío de pronosticar distribuciones futuras. En Herzog S.K., Martinez R., Jørgensen P.M., Tiessen H. (Eds). Cambio Climático y Biodiversidad en los Andes Tropicales. Instituto Interamericano para la Investigación del Cambio Global (IAI), Sao José dos Campos, y Comité Científico sobre problemas de Medio Ambiente (SCOPE), Paris. 426pp.

Guisan, A., Zimmermann, N.E., 2000. Predictive habitat distribution models in ecology. Ecol. Model. 135, 147-186.

Gutiérrez, J.A., Duivenvoorden, J.F., 2010. Can we expect to protect threatened species in protected areas? A case study of the genus Pinus in Mexico. Revista Mexicana de Biodiversidad. 81, 875-882.

Halvorsen, R., Mazzoni, S., Bryn, A. Bakkestuen, V., 2015. Opportunities for improved distribution modelling practice via a strict maximum likelihood interpretation of MaxEnt. Ecography. 38, 172-183.

Hampe, A., Petit, R.J., 2005. Conserving biodiversity under climate change: the rear edge matters. Ecol. Lett. 8, 461-467.

Hanberry, B.B., He, H.S., Palik, B.J., 2012. Pseudoabsence Generation Strategies for Species Distribution Models. PLoS ONE 7(8).

Hanski, I., Ovaskainen, O., 2002. Extinction Debt at Extinction Threshold. Conserv. Biol. 16, 666-673.

Harris, D.J., 2015. Generating realistic assemblages with a joint species distribution model. Methods Ecol. Evol. 6, 465-473.

Harris, R.M.B., Porfirio, L.L., Hugh, S., Lee, G., Bindoff, N.L., Mackey, B., 2013. To Be Or Not to Be ? Variable selection can change the projected fate of a threatened species under future climate. Ecol. Manage. Restor. 14, 230-234.

Heiberger, R.M., 2015. HH: Statistical Analysis and Data Display: Heiberger and Holland. R package version 3.1-24. 
Hellman, S., Gaillard, M.J., Broström, A., Sugita, S., 2008. The REVEALS model, a new tool to estimate past regional plant abundance from pollen data in large lakes: validation in southern Sweden. J. Quat. Sci. 23, 21-42.

Hernandez, P.A., Graham, C.H., Master, L.L., Albert, D.L., 2006. The effect of sample size and species characteristics on performance of different species distribution modeling methods. Ecography. 29, 773-785.

Herrero, A., Zavala, M.A., (Eds), 2015. Los Bosques y la Biodiversidad frente al Cambio Climático: Impactos, Vulnerabilidad y Adaptación en España. Ministerio de Agricultura, Alimentación y Medio Ambiente, Madrid.

Heuertz, M., Teufel, J., González-Martínez, S.C., Soto, A., Fady, B., Alía, R. Vendramin, G.G., 2010. Geography determines genetic relationships between species of mountain pine (Pinus mugo complex) in western Europe. J. Biogeogr. 37, 541-556.

Hicks, S., 2006. When no pollen does not mean no trees. Veg. Hist. Archaeobot. 15, 253-261.

Hicks, S., 2007. Surface Samples and Trapping. In: Elias, S., (Ed) Encyclopedia of Quaternary Science. Elsevier. pp. 2486-2497.

Hijmans, R.J., Cameron, S.E., Parra, J.L., Jones, P.G., Jarvis, A., 2005. Very high resolution interpolated climate surfaces for global land areas. Int. J. Climatol. 25, 1965-1978.

Hijmans, R.J., Elith, J., 2013. Species distribution modeling with R. R CRAN Project. URL: http://cran.r-project.org/web/packages/dismo/vignettes/sdm.pdf [accessed 14 January 2013]

Hijmans, R.J., Graham, C.H., 2006. The ability of climate envelope models to predict the effect of climate change on species distributions. Glob. Change Biol. 12, 2272-2281.

Hijmans, R.J., Phillips, S., Leathwick, J., Elith, J., 2015. dismo: Species Distribution Modeling. R package version 1.0-12. http://CRAN.R-project.org/package=dismo

Hu, J., Jiang, Z., 2011. Climate Change Hastens the Conservation Urgency of an Endangered Ungulate. PLoS ONE 6(8). 
Hutchinson, G.E., 1957. Concluding remarks. Cold Spring harbor Symposia on Quantitative Biology. 22, 415-427.

Hutchinson, M.F., 1991. The application of thin plate smoothing splines to continent-wide data assimilation. Data Assimilation Systems, J. D. Jasper, Ed., BMRC Research Report No. 27, Bureau of Meteorology, Melbourne, Australia, 104-113.

IFN3, 2008. (Tercer inventario Nacional Forestal, ES). "Tercer inventario Nacional Forestal". 1997-2007. Ministerio de Medio Ambiente. Consultado 10 de abr. de 2011. Disponible en http://www.magrama.gob.es/es/biodiversidad/servicios/banco-datosnaturaleza/informacion-disponible/ifn3.aspx

Iglesias, M., 1998. Relation végétation-pluie pollinique actuelle phytomasse epigée pérenne dans les steppes du Sud-Est de l'Espagne et du Nord-Est du Maroc. PhD Thesis, University of Paul Sabatier-Toulouse III, Toulouse.

IGN, 2013. Service de l'inventaire forestier et statistique. Institut national de l'information géographique et forestière (IGN). http://inventaire-forestier.ign.fr/

IPCC, 2007: Cambio climático 2007: Informe de síntesis. Contribución de los Grupos de trabajo I, II y III al Cuarto Informe de evaluación del Grupo Intergubernamental de Expertos sobre el Cambio Climático, in: Pachauri, R.K., Reisinger, A., (Eds.) IPCC, Ginebra.

IPCC, 2014: Climate Change 2013: The Physical Science Basis. Contribution of Working Group I to the Fifth Assessment Report of the Intergovernmental Panel on Climate Change in: Stocker, T.F., Qin, D., Plattner, G.K., Tignor, M., Allen, S.K., Boschung, J., Nauels, A., Xia, Y., Bex V., Midgley P.M. (Eds.), Cambridge University Press, Cambridge, United Kingdom and New York, NY, USA, 1535 pp.

Iversen, T., Bentsen, M., Bethke, I., Debernard, J.B., Kirkevåg, A., Seland, Ø., Drange, H., Kristjansson, J.E., Medhaug, I., Sand, M., Seierstad, I.A., 2013. The Norwegian earth system model, NorESM1-M-Part 2: climate response and scenario projections. Geosci. Model Dev. 6, 389-415. 
Jalas J., Suominen, J., (Eds) 1972-94. Atlas Florae Europaeae: Distribution of Vascular Plants in Europe, Vol. 1-10. The Committee for Mapping the Flora of Europe and Societas Biologica Fennica Vanamo. Helsinki.

Jennings, M.D. 2000 Gap analysis: concepts, methods, and recent results. Landsc. Ecol. 15, $5-20$.

Jiménez-Alfaro, B., García-Calvo, L., García, P., Acebes, J.L., 2016. Anticipating extinctions of glacial relict populations in mountain refugia. Biol. Conserv. 201, 243-251.

Johnson, J.B., Omland, K.S., 2004. Model selection in ecology and evolution. Trends Ecol. Evol. 19, 101-108.

Jungclaus, J.H., Fischer, N., Haak, H., Lohmann, K., Marotzke, J., Matei, D., Mikolajewicz, U., Notz, D., Von Storch, J.S., 2013. Characteristics of the ocean simulations in MPIOM, the ocean component of the MPI-Earth system model, J. Adv. Model. Earth Syst. 5, 422-446.

Kajba, D., Gračan., J. 2003. Euforgen Technical Guidelines for genetic conservation and use for black alder (Alnus glutinosa). International Plant Genetic Resources Institute, Rome, Italy. 4 pp.

Kearney, M.R., Wintle, B.A., Porter, W.P., 2010. Correlative and mechanistic models of species distribution provide congruent forecasts under climate change. Conserv Lett. 3 , 203-213.

Kerr, J.T., Ostrovsky, M., 2003. From space to species: ecological applications for remote sensing. Trends Ecol. Evol. 18, 299-305.

Kiehl, J.T., Gent, P.R., 2004. The Community Climate System Model, Version 2. J. Clim. 17, $3666-3682$.

Kumar, S., Stohlgren, T.J., 2009. Maxent modeling for predicting suitable habitat for threatened and endangered tree Canacomyrica monticola in New Caledonia. J. Ecol. Nat. Environ. 1, 94-98. 
Kuussaari, M., Bommarco, R., Heikkinen, R. K., Helm, A., Krauss, J., Lindborg, R., Öckinger, E., Pärtel, M., Pino, J., Rodà, F., et al., 2009. Extinction debt: a challenge for biodiversity conservation. Trends Ecol. Evol. 24, 564-571.

Lawson, C.R., Hodgson, J.A., Wilson, R.J., Richards, S.A., 2014. Prevalence, thresholds and the performance of presence-absence models. Methods Ecol. Evol. 5, 54-64.

Lenoir, J., Svenning, J.C., 2015. Climate-related range shifts-a global multidimensional synthesis and new research directions. Ecography. 38, 15-28.

Lima-Ribeiro, M.S., Nogués-Bravo, D., Terribile, L.C., Batra, P., Diniz-Filho, J.A.F., 2013. Climate and humans set the place and time of Proboscidean extinction in late Quaternary of South America. Palaeogeogr. Palaeoclimatol. Palaeoecol. 392, 546-556.

Lisitsyna, O. V., Giesecke, T., Hicks, S., 2011. Exploring pollen percentage threshold values as an indication for the regional presence of major European trees. Rev. Palaeobot. Palynol. 166, 311-324.

Lobo, J.M., Jiménez-Valverde, A., Real, R., 2008. AUC: a misleading measure of the performance of predictive distribution models. Glob. Ecol. Biogeogr. 17, 145-151.

Lorenzen, E.D., Nogués-Bravo, D., Orlando, L., Weinstock, J., Binladen, J., Marske, K.A., Ugan, A., Borregaard, M.K., Gilbert M.T.P., Nielsen, R., Ho, S.Y., 2011. Speciesspecific responses of Late Quaternary megafauna to climate and humans. Nature. 479, 359-364.

Macias-Fauria, M., Willis, K.J., 2013. Landscape planning for the future: using fossil records to independently validate bioclimatic envelope models for economically valuable tree species in Europe. Glob. Ecol. Biogeogr. 22, 318-333.

Magri, D., Fineschi, S., Bellarosa, R., Buonamici, A., Sebastiani, F., Schirone, B., Simeone, M.C., Vendramin, G.G., 2007. The distribution of Quercus suber chloroplast haplotypes matches the palaeogeographical history of the western Mediterranean. Mol. Ecol. 16, $5259-5266$. 
Maguire, K.C., Nieto-Lugilde, D., Fitzpatrick, M.C., Williams, J.W., Blois, J.L., 2015. Modeling species and community responses to past, present, and future episodes of climatic and ecological change. Annu. Rev. Ecol. Evol. Syst. 46, 343-368.

Maiorano, L., Cheddadi, R., Zimmermann, N.E., Pellissier, L., Petitpierre, B., Pottier, J., Laborde H., Hurdu B.I., Pearman, P.B., Psomas A., et al., 2013. Building the niche through time: Using 13,000 years of data to predict the effects of climate change on three tree species in Europe. Glob. Ecol. Biogeogr. 22, 302-317.

Martín, S., Díaz-Fernández, P., De Miguel, J., 1998. Regiones de procedencia de las especies forestales españolas. Géneros Abies, Fagus, Pinus y Quercus. Dirección General de Conservación de la Naturaleza. Madrid.

Martínez-Meyer, E., Peterson, A.T., 2006. Conservatism of ecological niche characteristics in North American plant species over the Pleistocene-to-Recent transition. J. Biogeogr. 33, 1779-1789.

Martínez-Meyer, E., Townsend Peterson, A., Hargrove, W.W., 2004. Ecological niches as stable distributional constraints on mammal species, with implications for Pleistocene extinctions and climate change projections for biodiversity. Glob. Ecol. Biogeogr. 13, 305-314.

Mateo, R.G., Croat, T.B., Felicísimo, A.M., Muñoz, J., 2010. Profile or group discriminative techniques? Generating reliable species distribution models using pseudo-absences and target-group absences from natural history collections. Divers. Distrib. 16, 84-94.

Mateo, R.G., Felicísimo, A.M., Muñoz, J., 2011. Species distributions models: A synthetic revision. Rev. Chil. Hist. Nat. 84, 217-240.

Mateo, R.G., Vanderpoorten, A., Muñoz, J., Laenen, B., Désamoré, A., 2013. Modeling species distributions from heterogeneous data for the biogeographic regionalization of the European bryophyte flora. PloS ONE. 8.

Maxent. URL: http://www.cs.princeton.edu/ schapire/maxent/ [accessed 14 November 2011] 
McPherson, J., Jetz, W., Rogers, D., 2004. The effects of species' range sizes on the accuracy of distribution models: ecological phenomenon or statistical artefact? J. Appl. Ecol. 41, $811-823$.

Merow, C., Smith, M.J., Edwards, T.C., Guisan, A., McMahon, S.M., Normand, S., Thuiller, W., Wüest, R.O., Zimmermann, N.E., Elith, J., 2014. What do we gain from simplicity versus complexity in species distribution models? Ecography. 37, 1267-1281.

Merow, C., Smith, M.J., Silander, J.A., 2013. A practical guide to MaxEnt for modeling species' distributions: what it does, and why inputs and settings matter. Ecography 36, $1058-1069$.

Miller, J., 2010. Species distribution modeling. Geogr. Compass. 4, 490-509.

Monjo, R., Caselles, V., Chust, G., 2014. Probabilistic correction of RCM precipitation in the Basque Country (Northern Spain). Theor. Appl. Climatol. 117, 317-329.

Moore, P.D., Webb, J.A., Collison, M.E., 1991. Pollen analysis. Blackwell scientific publications.

Moreno, M.V. Chuvieco, E., 2009. Validación de productos globales de cobertura del suelo en la España Peninsular. Revista de Teledetección. 31, 5-22.

Moreno, J.M., Rosa, D.D.L., Zazo, C., 2005. Evaluación preliminar de los impactos en España por efecto del cambio climático. España. Ministerio de Medio Ambiente.

Moreno-Amat, E., Mateo, R.G., Nieto-Lugilde, D., Morueta-Holme, N., Svenning, J.C., García-Amorena, I., 2015. Impact of model complexity on cross-temporal transferability in Maxent species distribution models: An assessment using paleobotanical data. Ecol. Model. 312, 308-317.

Morin, X., Thuiller, W., 2009. Comparing niche-and process-based models to reduce prediction uncertainty in species range shifts under climate change. Ecology. 90, 13011313 
Morueta-Holme, N., Engemann, K., Sandoval-Acuña, P., Jonas, J.D., Segnitz, R.M., Svenning, J.C., 2015. Strong upslope shifts in Chimborazo's vegetation over two centuries since Humboldt. Proc. Natl. Acad. Sci. USA. 112, 12741-12745.

Morueta-Holme, N., Fløjgaard, C., Svenning, J.C., 2010. Climate change risks and conservation implications for a threatened small-range mammal species. PloS ONE. 5.

Muscarella R., Galante, P.J., Soley-Guardia, M., Boria, R.A., Kass, J.M., Uriarte, M., Anderson, R.P., 2014. ENMeval: An R package for conductiong spatially independent evaluations and estimating optimal model complexity for Maxent ecological niche models. Methods Ecol. Evol. 5, 1198-1205.

Nenzén, H.K., Araújo, M.B., 2011. Choice of threshold alters projections of species range shifts under climate change. Ecol. Model. 222, 3346-3354.

Neotoma Paleoecology Database (NeotomaDB). URL: http://www.neotomadb.org/ [accessed 15 September 2014]

Newbold, T., 2010. Applications and limitations of museum data for conservation and ecology, with particular attention to species distribution models. Prog. Phys. Geogr. 34, $3-22$.

Nieto-Lugilde, D., Maguire, K.C., Blois, J.L., Williams, J.W., Fitzpatrick, M.C., 2015. Close agreement between pollen-based and forest inventory-based models of vegetation turnover. Glob. Ecol. Biogeogr. 24, 905-916.

Ninyerola, M., Pons, X., Roure, J.M., 2005. Atlas Climático Digital de la Península ibérica. Metodología y aplicaciones en bioclimatología y geobotánica. Univ. Autónoma de Barcelona. Bellaterra, 44 pp.

Nogués-Bravo, D., 2009. Predicting the past distribution of species climatic niches. Glob. Ecol. Biogeogr. 18, 521-531.

Nogués-Bravo, D., Rodríguez, J., Hortal, J., Batra, P. Araújo, M.B., 2008. Climate change, humans, and the extinction of the woolly mammoth. PLoS Biology. 6, e79. 
North American Pollen Database URL: http://www.ncdc.noaa.gov/paleo/napd.html [accessed 15 September 2014]

Palacio, J.L., Bocco, G., Velásquez, A., Mas, J.F., Takaki, F., Vistoria, A., Luna, L., Gómez, G., López, M., Palma, M., et al., 2000. La condición actual de los recursos forestales en México: resultados del inventario forestal nacional 2000. Boletín del Instituto de Geografía. Investigaciones Geográficas, UNAM. 43, 183-203.

Paleoclimate Modelling Intercomparison Project (PMIP2) URL: http://pmip2.lsce.ipsl.fr/

Paleodiversitas, 2011. Sistema de información sobre Paleoflora y Paleovegetación de la Península ibérica. URL: http://www.paleodiversitas.org/ [accessed 23 January 2012].

Pearman, P.B., Randin, C.F., Broennimann, O., Vittoz, P., van der Knaap, W.O., Engler, R., Le Lay, G., Zimmermann, N.E., Guisan, A., 2008. Prediction of plant species distributions across six millennia. Ecol. Lett. 11, 357-69.

Pearson, R.G., Raxworthy, C.J., Nakamura, M., Townsend Peterson, A., 2007. Predicting species distributions from small numbers of occurrence records: a test case using cryptic geckos in Madagascar. J. Biogeogr. 34, 102-117.

Peterson, A.T., Knapp, S., Guralnick, R., Soberón, J. Holder, M., 2010. The big questions for biodiversity informatics. Syst. Biodivers. 8, 159-168.

Peterson, A.T., Nyári, Á., 2008. Ecological niche conservatism and Pleistocene refugia in the thrush-like mourner, Schiffornis sp., in the Neotropics. Evolution. 62, 173-183.

Peterson, A.T., Soberón, J., Sánchez-Cordero, V., 1999. Conservatism of ecological niches in evolutionary time. Science. 285, 1265-1267.

Phillips, S.J., Anderson, R.P., Schapire, R.E., 2006. Maximum entropy modeling of species geographic distributions. Ecol. Model. 190, 231-259.

Phillips, S.J., Dudík, M., 2008. Modeling of species distributions with Maxent: new extensions and a comprehensive evaluation. Ecography, 31, 161-175. 
Phillips, S.J., Dudík, M., Elith, J., Graham, C.H., Lehmann, A., Leathwick, J., Ferrier, S., 2009. Sample selection bias and presence-only distribution models: implications for background and pseudo-absence data. Ecol. Appl. 19, 181-197.

Pidek, I.A., Svitavská-Svobodová, H., Van der Knaap, W.O., Magyari, E., 2013. Pollen percentage thresholds of Abies alba based on 13-year annual records of pollen deposition in modified Tauber traps: perspectives of application to fossil situations. Rev. Palaeobot. Palynol. 195, 26-36.

Poelchau, M.F., Hamrick, J.L., 2013. Palaeodistribution modelling does not support disjunct Pleistocene refugia in several Central American plant taxa. J. Biogeogr. 40, 662-675.

Poska, A., Pidek, I.A., 2010. Pollen dispersal and deposition characteristics of Abies alba, Fagus sylvatica and Pinus sylvestris, Roztocze region (SE Poland). Veg. Hist. Archaeobot. 19, 91-101.

Prentice, C., 1988. Records of vegetation in time and space: the principles of pollen analysis. In: Huntley, B., Webb, T., (Eds) Vegetation history. Springer Netherlands. pp. 17-42.

Prentice, I.C., Cramer, W., Harrison, S.P., Leemans, R., Monserud, R.A., Solomon A.M. 1992. A global biome model based on plant physiology and dominance, soil properties and climate. J. Biogeogr. 19, 117-134.

Radosavljevic, A., Anderson, R.P., 2014. Making better Maxent models of species distributions: complexity, overfitting and evaluation. J. Biogeogr. 41, 629-643.

Ralska-Jasiewiczowa, M., Latałowa, M., Wasylikowa, K., Tobolski, K., Madeyska, E., Wright, Jr. H.E., Turner, C. (Eds.), 2004. Late Glacial and Holocene history of vegetation in Poland based on isopollen maps. W. Szafer Institute of Botany, Polish Academy of Sciences, Kraków.

R Core Team, 2015. R: A language and environment for statistical computing. R Foundation for Statistical Computing, Vienna, Austria. URL https://www.R-project.org/.

Record, S., Fitzpatrick, M.C., Finley, A.O., Veloz, S., Ellison, A.M., 2013. Should species distribution models account for spatial autocorrelation? A test of model projections across eight millennia of climate change. Glob. Ecol. Biogeogr. 22, 760-771. 
Reimer, P.J., Baillie, M.G.L., Bard, E., Bayliss, A., Beck, J.W., Blackwell, P.G., Bronk Ramsey, C., Buck, C.E., Burr, G.S., Edwards, R.L., et al., 2009. IntCal09 and Marine09 radiocarbon age calibration curves, 0-50,000 years cal BP. Radiocarbon. 51, 1111-1150.

Reimer, P.J., Bard, E., Bayliss, A., Beck, J. W., Blackwell, P. G., Bronk Ramsey, C., Buck, C.E.. Cheng, H., Edwards, R.L., Friedrich, M., et al., 2013. IntCal13 and Marine13 radiocarbon age calibration curves 0-50,000 years cal BP. Radiocarbon. 55, 1869-1887.

Renner, I.W., Warton, D.I., 2013. Equivalence of MAXENT and Poisson point process models for species distribution modeling in ecology. Biometrics. 69, 274-81.

Ribalaygua, J., Torres, L., Pórtoles, J., Monjo, R., Gaitán, E., Pino, M.R., 2013. Description and validation of a two-step analogue/regression downscaling method. Theor. Appl. Climatol. 114, 253-269.

Roberts, D.R., Hamann, A., 2012a. Predicting potential climate change impacts with bioclimate envelope models: a palaeoecological perspective. Glob. Ecol. Biogeogr. 21, $121-133$.

Roberts, D.R., Hamann, A., 2012b. Method selection for species distribution modelling: are temporally or spatially independent evaluations necessary?. Ecography. 35, 792-802.

Rodríguez-Sánchez, F., Arroyo, J., 2008. Reconstructing the demise of Tethyan plants: climate-driven range dynamics of Laurus since the Pliocene. Glob. Ecol. Biogeogr. 17, 685-695.

Rodríguez-Sánchez, F., Hampe, A., Jordano, P., Arroyo, J., 2010. Past tree range dynamics in the Iberian Peninsula inferred through phylogeography and palaeodistribution modelling: a review. Rev. Palaeobot. Palynol. 162, 507-521.

Rosenzweig, C., Karoly, D., Vicarelli, M., Neofotis, P., Wu, Q., Casassa, G., Menzel, A, Root, T.L., Estrella, N, Seguin, B, et al., 2008. Attributing physical and biological impacts to anthropogenic climate change. Nature. 453, 353-357.

Rubiales, J.M., García-Amorena, I., Hernández, L., Génova, M., Martínez, F., Manzaneque, F. G., Morla, C., 2010. Late Quaternary dynamics of pinewoods in the Iberian Mountains. Rev. Palaeobot. Palynol. 162, 476-491. 
Ruiz de la Torre, J., 2006. Flora mayor. Dirección General para la Biodiversidad. Ministerio de Medio Ambiente, Madrid.

Sandel, B., Arge, L., Dalsgaard, B., Davies, R.G., Gaston, K.J., Sutherland, W.J., Svenning, J.C., 2011. The influence of Late Quaternary climate-change velocity on species endemism. Science. 334, 660-664.

Saveraid, E.H., Debinski, D.M., Kindscher, K., Jakubauskas, M.E., 2001. A comparison of satellite data and landscape variables in predicting bird species occurrences in the Greater Yellowstone Ecosystem, USA. Landsc. Ecol. 16, 71-83.

Schoener, T.W., 1968. The Anolis lizards of Bimini: resource partitioning in a complex fauna. Ecology. 49, 704-726.

Schwartz, M.W., 2012. Using niche models with climate projections to inform conservation management decisions. Biol. Conserv. 155, 149-156.

Schweingruber, F., 1990. Anatomy of European woods. WSL/FNP, Paul Haupt Berne and Stuttgart Publishers.

Segurado, P., Araújo, M., 2004. An evaluation of methods for modelling species distributions. J. Biogeogr. 31, 1555-1568.

Seppä, H., Alenius, T., Muukkonen, P., Giesecke, T., Miller, P.A., Ojala, A.E., 2009. Calibrated pollen accumulation rates as a basis for quantitative tree biomass reconstructions. Holocene. 19, 209-220.

Settele J., Kudrna O., Harpke A., Kühn I., Van Swaay C., Verovnik R., Warren M., Wiemers M., Hanspach J., Hickler T., et al., 2008. Climatic risk Atlas of European Butterflies. BIORISK, Biodiversity and Ecosystem Risk Assessment. 1, 1-710. Pensoft, Sofia, Moscow.

Shcheglovitova, M., Anderson, R.P., 2013. Estimating optimal complexity for ecological niche models: A jackknife approach for species with small sample sizes. Ecol. Model. 269, 9-17. 
Sinclair, S.J., White, M.D., Newell, G.R., 2010. How useful are species distribution models for managing biodiversity under future climates. Ecol. Soc. 15.

Soberón, J., 2011. (http://nicho.conabio.gob.mx/).

Soberón, J., Nakamura, M., 2009. Niches and distributional areas: concepts, methods and assumptions. Proc. Natl. Acad. Sci. U.S.A. 106, 19644-19650.

Soberón, J., Peterson, AT., 2005. Interpretation of models of fundamental ecological niches and species' distributional areas. Biodiv. Inf. 2, 1-10.

Soley-Guardia, M., Gutiérrez, E.E., Thomas, D.M., Ochoa-G, J., Aguilera, M., Anderson, R.P., 2016. Are we overestimating the niche? Removing marginal localities helps ecological niche models detect environmental barriers. Ecol. Evol. 6, 1267-1279.

Stigall, A.L., 2012. Using ecological niche modelling to evaluate niche stability in deep time. J. Biogeogr. 39, 772-781.

Stuiver, M., Reimer, P.J., 1993. Extended 14C database and revised CALIB radiocarbon calibration program. Radiocarbon. 35, 215-230.

Stuiver, M., Reimer, P.J., Reimer, R.W., 2005. CALIB 5.0. URL: http://calib.qub.ac.uk/calib/

Stuiver, M., Reimer, P.J., Reimer, R., 2012. Calib 6.0 URL: http://radiocarbon.pa.qub.ac.uk/calib/calib.html [accessed 23 January 2012].

Sugita, S., 2007a. Theory of quantitative reconstruction of vegetation I: pollen from large sites REVEALS regional vegetation. Holocene. 17, 229-241

Sugita, S., 2007b. Theory of quantitative reconstruction of vegetation II: all you need is LOVE. Holocene. 17, 243-25

Svenning, J.C., Fløjgaard, C., Marske, K. A., Nógues-Bravo, D., Normand, S., 2011. Applications of species distribution modeling to paleobiology. Quat. Sci. Rev. 30, 29302947.

Svenning, J.C., Normand, S., Kageyama, M., 2008. Glacial refugia of temperate trees in Europe: insights from species distribution modelling. J. Ecol. 96, 1117- 1127. 
Svenning, J.C., Skov, F., 2004, Limited filling of the potential range in European tree species. Ecol. Lett. 7, 565-573.

Svenning, J.C., Skov, F., 2007. Ice age legacies in the geographical distribution of tree species richness in Europe. Glob. Ecol. Biogeogr. 16, 234-245.

Syfert, M.M., Smith, M.J., Coomes, D.A., 2013. The effects of sampling bias and model complexity on the predictive performance of MaxEnt species distribution models. PloS ONE. 8.

Synes, N.W., Osborne, P.E., 2011. Choice of predictor variables as a source of uncertainty in continental-scale species distribution modelling under climate change. Glob. Ecol. Biogeogr. 20, 904-914.

Szczepanek, K., Tobolski, K., Nalepka, D., 2004. Alnus Mill. - Alder. In: RalskaJasiewiczowa, M., Latałowa, M., Wasylikowa, K., Tobolski, K., Madeyska, E., Wright Jr., H.E., Turner, C. (Eds.) Late Glacial and Holocene history of vegetation in Poland based on isopollen maps. W. Szafer Institute of Botany, Polish Academy of Sciences, Kraków, pp. 47-55.

Taylor, K.E., Stouffer, R.J., Meehl, G., 2009. A Summary of the CMIP5 Experiment Design. World. 4, 1-33.

Thompson, R.S., Anderson, K.H., 2000. Biomes of western North America at 18,000, 6000 and $0 \mathrm{C}-14 \mathrm{yr}$ BP reconstructed from pollen and packrat midden data. J. Biogeogr. 27, $555-584$.

Thuiller, W., Lavorel, S., Araújo, M.B., Sykes, M.T., Prentice, I.C., 2005. Climate change threats to plant diversity in Europe. Proc. Natl. Acad. Sci. U.S.A. 102, 8245-8250.

Tinner, W., Kaltenrieder, P., 2005. Rapid responses of high-mountain vegetation to early Holocene environmental changes in the Swiss Alps. J. Ecol. 93, 936-947.

Tutin, T.G., et al., (Ed.). 1964. Flora europaea. - Cambridge University Press.

UICN, 2012. Categorías y Criterios de La Lista Roja de la UICN: Versión 3.1. Segunda edición. Gland, Suiza y Cambridge. Reino Unido: UICN. 34 pp. 
USGS, 2004. Shuttle Radar Topography Mission, 3 Arc Second scene. Global Land Cover Facility, URL: www.landcover.org.

Vale, C.G., Tarroso, P., Brito, J.C., 2014. Predicting species distribution at range margins: testing the effects of study area extent, resolution and threshold selection in the SaharaSahel transition zone. Divers. Distrib. 20, 20-33.

Valladares, F., Matesanz, S., Guilhaumon, F., Araújo, M.B., Balaguer, L., Benito-Garzón, M., Cornwell, W., Gianoli, E., Van Kleunen, M., Naya, D.E., et al., 2014. The effects of phenotypic plasticity and local adaptation on forecasts of species range shifts under climate change. Ecol. Lett. 17, 1351-1364.

Valladares, F., Peñuelas, J., Calabuig, E.L., 2005. Impactos sobre los ecosistemas terrestres, in: Moreno, J.M. (Ed.) Evaluación Preliminar de los Impactos en España por Efecto del Cambio Climático. Ministerio de Medio Ambiente. Madrid. pp. 65-112.

Van der Knaap, W.O., Van Leeuwen, J.F.N., Finsinger, W., Gobet, E., Pini, R., Schweizer, A., Valsecchi, V., Ammann, B., 2005. Migration and population expansion of Abies, Fagus, Picea, and Quercus since 15000 years in and across the Alps, based on pollenpercentage threshold values. Quat. Sci. Rev. 24, 645-680.

Varela, S., Anderson, R.P., García-Valdés, R., Fernández-González, F., 2014. Environmental filters reduce the effects of sampling bias and improve predictions of ecological niche models. Ecography. 37, 1084-1091.

Varela, S., Lobo, J.M., Hortal, J., 2011. Using species distribution models in paleobiogeography: a matter of data, predictors and concepts. Palaeogeogr. Palaeoclimatol. Palaeoecol. 310, 451-463.

Varela, S., Lima-Ribeiro, M.S., Terribile, L.C., 2015a. A Short Guide to the Climatic Variables of the Last Glacial Maximum for Biogeographers. PLoS ONE 10, e0129037.

Varela, S., González-Hernández, J., Sgarbi, L.F., Marshall, C., Uhen, M.D., Peters, S., McClennen, M., 2015b. PaleobioDB: an R package for downloading, visualizing and processing data from the Paleobiology Database. Ecography. 38, 419-425 
Vaughan, I.P., Ormerod, S.J., 2003. Improving the quality of distribution models for conservation by addressing shortcomings in the field collection of training data. Conserv. Biol.17, 1601-1611.

Veloz, S.D., 2009. Spatially autocorrelated sampling falsely inflates measures of accuracy for presence-only niche models. J. Biogeogr. 36, 2290-2299.

Vessella, F., Simeone, M.C., Schirone, B., 2015. Quercus suber range dynamics by ecological niche modelling: from the Last Interglacial to present time. Quat. Sci. Rev. 119, 85-93.

Waltari, E., Guralnick, R.P., 2009. Ecological niche modelling of montane mammals in the Great Basin, North America: examining past and present connectivity of species across basins and ranges. J. Biogeogr. 36, 148-161.

Warren, D.L., Glor, R.E., Turelli, M., 2010. ENMTools: a toolbox for comparative studies of environmental niche models. Ecography. 1, 607-611.

Warren, D.L., Seifert, S.N., 2011. Ecological niche modeling in Maxent: the importance of model complexity and the performance of model selection criteria. Ecol. Appl. 21, 335342.

Warren, D.L., Wright, A.N., Seifert, S.N., Shaffer, H.B., 2014. Incorporating model complexity and spatial sampling bias into ecological niche models of climate change risks faced by 90 California vertebrate species of concern. Divers. Distrib. 20, 334-343.

Werneck, F.P., Nogueira, C., Colli, G.R., Sites, J.W., Costa, G.C., 2012. Climatic stability in the Brazilian Cerrado: implications for biogeographical connections of South American savannas, species richness and conservation in a biodiversity hotspot. J. Biogeogr. 39, 1695-1706.

Williams, J.W., Shuman, B.N., Webb, T., Bartlein, P.J., Leduc, P.L., 2004. Late Quaternary vegetation dynamics in North America: scaling from taxa to biomes. Ecol. Monogr. 74, 309-334.

Williams, J.W., Kharouba, H.M., Veloz, S., Vellend, M., McLachlan, J., Liu, Z., OttoBliesner, B., He, F., 2013a. The ice age ecologist: testing methods for reserve prioritization during the last global warming. Glob. Ecol. Biogeogr. 22, 289-301. 
Williams, J.W., Blois, J.L., Gill, J.L., Gonzales, L.M., Grimm, E.C., Ordoñez, A., Shuman, B., Veloz, S.D., 2013b. Model systems for a no-analog future: species associations and climates during the last deglaciation. Ann. N. Y. Acad. Sci. 1297, 29-43.

Williams-Tripp, M., D'Amico, F.J.N., Pagé, C., Bertrand, A., Némoz, M., Brown, J.A., 2012. Modeling rare species distribution at the edge: the case for the vulnerable endemic Pyrenean desman in France. Scientific World J.

Willis, K.J., Bailey, R.M., Bhagwat, S.A., Birks, H.J.B., 2010. Biodiversity baselines, thresholds and resilience: testing predictions and assumptions using palaeoecological data. Trends Ecol. Evol. 25, 583-591.

Wisz, M.S., Hijmans, R.J., Li, J., Peterson, A.T., Graham, C.H., Guisan, A., 2008. Effects of sample size on the performance of species distribution models. Divers. Distrib. 14, 763773.

Wolf, H., 2003. EUFORGEN Technical Guidelines for genetic conservation and use for silver fir (Abies alba). International Plant Genetic Resources Institute, Rome, Italy.

Worldclim URL: http://www.worldclim.org/ [accessed january 2012]

Yackulic, C.B., Chandler, R., Zipkin, E.F., Royle, J.A., Nichols, J.D., Campbell Grant, E.H., Veran, S., 2013. Presence-only modelling using MAXENT: when can we trust the inferences? Methods Ecol. Evol. 4, 236-243.

Zimmermann, N.E., Edwards, T.C., Moisen, G.G., Frescino, T.S., Blackard, J.A., 2007. Remote sensing-based predictors improve distribution models of rare, early successional and broadleaf tree species in Utah. J. Appl. Ecol. 44, 1057-1067.

Zorita, E., Von Storch, H., 1999. The analog method as a simple statistical downscaling technique: comparison with more complicated methods. J. Clim. 12, 2474-2489. 


\section{SOFTWARE UTILIZADO}

ArcMap 10.1: ESRI, 2011. ArcGIS Desktop: Release 10. Redlands, CA: Environmental Systems Research Institute.

dismo package: Hijmans, R.J., Phillips, S., Leathwick, J., Elith, J., 2015. dismo: Species Distribution Modeling. R package version 1.0-12. http://CRAN.R-project.org/package=dismo

ENMeval package: Muscarella, R., Galante, P.J., Soley-Guardia, M., Boria, R.A., Kass, J., Uriarte, M. Anderson, R.P., 2014. ENMeval: An R package for conducting spatially independent evaluations and estimating optimal model complexity for ecological niche models. Methods Ecol. Evol.

ENMtools: Warren, D.L., Glor, R.E., Turelli, M., 2010. ENMTools: a toolbox for comparative studies of environmental niche models. Ecography. 1, 607-611, http://dx.doi.org/10.1111/j.1600-0587.2009.06142.xWarren

HH package: Heiberger, R.M., 2015. HH: Statistical Analysis and Data Display: Heiberger and Holland. R package version 3.1-24. http://CRAN.R-project.org/package=HH

Maxent: Phillips, S.J., Anderson, R.P., Schapire, R.E., 2006. Maximum entropy modeling ofspecies geographic distributions. Ecol. Model. 190, 231-259, http://dx.doi.org/10.1016/j.ecolmodel.2005.03.026.

http://www.cs.princeton.edu/ schapire/maxent/

raster package: Hijmans, R.J., 2015. raster: Geographic Data Analysis and Modeling. R package version 2.4-20. http://CRAN.R-project.org/package=raster

rgdal package: Bivand, R., Keitt, T., Rowlingson, B., 2015. rgdal: Bindings for the Geospatial Data Abstraction Library. $\mathrm{R}$ package version 1.1-1. http://CRAN.Rproject.org/package $=$ rgdal

rJava package: Urbanek, S., 2016. rJava: Low-Level R to Java Interface. R package version 0.9-8. http://CRAN.R-project.org/package=rJava

R studio: R Core Team, 2015. R: A language and environment for statistical computing. R Foundation for Statistical Computing, Vienna, Austria. https://www.R-project.org/. 
vegan package: Oksanen, J., Blanchet, F.G., Kindt, R., Legendre, P., Minchin, P.R., O'Hara, R.B., Simpson, G.L., Solymos, P., Henry, M., Stevens, H., Wagner, H., 2016. vegan: Community Ecology Package. $\mathrm{R}$ package version 2.3-3. http://CRAN.Rproject.org/package $=$ vegan 


\section{ANEXO DE PUBLICACIONES}

ANEXO 1. Moreno-Amat, E., Mateo, R.G., Nieto-Lugilde, D., Morueta-Holme, N., Svenning, J.C., García-Amorena, I. 2015. Impact of model complexity on cross-temporal transferability in Maxent species distribution models: An assessment using paleobotanical data. Ecological Modelling. 312, 308-317. 


\title{
Impact of model complexity on cross-temporal transferability in Maxent species distribution models: An assessment using paleobotanical data
}

\author{
Elena Moreno-Amat ${ }^{\mathrm{a}, *}$, Rubén G. Mateo ${ }^{\mathrm{a}, \mathrm{b}}$, Diego Nieto-Lugilde ${ }^{\mathrm{c}, \mathrm{d}}$, \\ Naia Morueta-Holme ${ }^{\mathrm{d}, \mathrm{e}}$, Jens-Christian Svenning ${ }^{\mathrm{d}}$, Ignacio García-Amorena ${ }^{\mathrm{a}}$ \\ a Departamento de Sistemas y Recursos Naturales, Universidad Politécnica de Madrid, Ciudad Universitaria s/n, 28040 Madrid, Spain \\ ${ }^{\mathrm{b}}$ Department of Ecology \& Evolution, University of Lausanne, Biophore Building, 1015 Lausanne, Switzerland \\ c Departmento de Botánica, Facultad de Ciencias, Universidad de Granada, 18071 Granada, Spain \\ d Section for Ecoinformatics and Biodiversity, Department of Bioscience, Aarhus University, Ny Munkegade 114, DK-8000 Aarhus C, Denmark \\ e Department of Integrative Biology, University of California-Berkeley, 3040 VLSB, Berkeley, CA 94720, USA
}

\section{A R T I C L E I N F O}

\section{Article history:}

Received 6 February 2015

Received in revised form 30 May 2015

Accepted 31 May 2015

\section{Keywords:}

Pollen fossil

Corylus avellana

Alnus glutinosa

Model validation

Species distribution model

$\beta$-Multiplier

\begin{abstract}
A B S T R A C T
Maximum entropy modeling (Maxent) is a widely used algorithm for predicting species distributions across space and time. Properly assessing the uncertainty in such predictions is non-trivial and requires validation with independent datasets. Notably, model complexity (number of model parameters) remains a major concern in relation to overfitting and, hence, transferability of Maxent models. An emerging approach is to validate the cross-temporal transferability of model predictions using paleoecological data. In this study, we assess the effect of model complexity on the performance of Maxent projections across time using two European plant species (Alnus glutinosa (L.) Gaertn. and Corylus avellana L.) with an extensive late Quaternary fossil record in Spain as a study case. We fit 110 models with different levels of complexity under present time and tested model performance using AUC (area under the receiver operating characteristic curve) and AICc (corrected Akaike Information Criterion) through the standard procedure of randomly partitioning current occurrence data. We then compared these results to an independent validation by projecting the models to mid-Holocene (6000 years before present) climatic conditions in Spain to assess their ability to predict fossil pollen presence-absence and abundance. We find that calibrating Maxent models with default settings result in the generation of overly complex models. While model performance increased with model complexity when predicting current distributions, it was higher with intermediate complexity when predicting mid-Holocene distributions. Hence, models of intermediate complexity resulted in the best trade-off to predict species distributions across time. Reliable temporal model transferability is especially relevant for forecasting species distributions under future climate change. Consequently, species-specific model tuning should be used to find the best modeling settings to control for complexity, notably with paleoecological data to independently validate model projections. For cross-temporal projections of species distributions for which paleoecological data is not available, models of intermediate complexity should be selected.
\end{abstract}

(c) 2015 Elsevier B.V. All rights reserved.

\section{Introduction}

Species distribution models (SDMs) are widely used algorithms for describing ecological patterns and estimating the ecological niche or the potential distribution of species across space and time (Elith and Leathwick, 2009). Mechanistic SDMs use functional traits

\footnotetext{
* Corresponding author. Tel.: +34 913367083.

E-mail address: emorenoamat@gmail.com (E. Moreno-Amat).
}

and physiological constraints to predict the response of an individual (or a population) to environmental conditions (Kearney et al., 2010; Morin and Thuiller, 2009), whilst correlative SDMs relate species known occurrences and environmental variables (Guisan and Zimmermann, 2000). While mechanistic models may provide a more reliable and realistic picture because they can include processes that limit species distribution (Kearney et al., 2010), correlative models are the most frequently used in climate change studies (Araújo and Peterson, 2012) and to inform decision-making in conservation (Araújo et al., 2011). For that reason, evaluating the uncertainty and predictive ability of correlative SDMs is crucial. 
Model complexity is well known to affect uncertainty of models and their transferability across space and time (Warren et al., 2014). However, the complexity of models is usually disregarded, especially when projecting SDMs across time. In addition, evaluating models requires occurrences independent from the calibration datasets, particularly when projecting models into the future, where such data are lacking (Araújo et al., 2005). One approach is to project models back in time and validate them with paleoecological data (Svenning et al., 2011). For example, paleobotanical records, which provide information on vegetation composition of the past, can be used as independent datasets to validate the past predictions of SDMs calibrated on present-day plant distributions (e.g. Pearman et al., 2008; Record et al., 2013, among others). Model complexity, defined as the number of parameters included in a model, is crucial for inferring habitat quality and estimating the breadth of species' niches (Warren and Seifert, 2011). Besides, complexity can also negatively affect the predictive performance of a model as a result of overfitting (Warren and Seifert, 2011). Although recent studies have assessed different aspects of complexity on SDM performance (e.g. Merow et al., 2014; Muscarella et al., 2014; Syfert et al., 2013; Warren and Seifert, 2011, among others), only one study has explored the uncertainty associated with model complexity on SDM projections for future climate scenarios (Warren et al., 2014). However, the effects of complexity on the predictive ability of SDMs across time remain poorly known.

Among the different SDM algorithms, maximum entropy (Maxent; Phillips et al., 2006) is extensively used for projecting current species distributions to different time periods (Elith and Leathwick, 2009). Maxent is a very flexible modeling algorithm widely used because of its better predictive performance relative to other modeling algorithms (Elith et al., 2006) even with low sample sizes (Pearson et al., 2007), its applicability to presence-only data (Phillips et al., 2006), and its user-friendly interface as well as availability through the dismo package (Hijmans and Elith, 2013). Maxent has been described as a modeling method able to fit overly complex response curves (Elith and Leathwick, 2009), particularly when using default parameters (Merow et al., 2013). Recently Maxent has been proved to be mathematically equivalent to a Poisson regression, a particular type of generalized linear models (GLM; Renner and Warton, 2013). The default settings of Maxent have been tested over a wide range of species and environmental conditions (Phillips and Dudík, 2008), but not in relation to cross-temporal transferability.

The complexity of Maxent models can be adjusted mainly through the choice of (1) the number of environmental predictors, (2) the feature classes allowed, and (3) the regularization ( $\beta$-multiplier) selected in the model. The initial selection of the number of environmental predictors that best describe the species' ecological niche has a great influence on model performance (Harris et al., 2013; Synes and Osborne, 2011). Generally, this selection is based on previous knowledge of the ecology of the species and/or statistical assessments (Morueta-Holme et al., 2010). The Maxent algorithm consists of an iterative process that automatically selects the features that best explain the species' distribution (Merow et al., 2013). Features are basis functions and other transformations of the environmental predictors (i.e. linear, quadratic, product - i.e. interaction between variables - threshold and/or hinge; Phillips and Dudík, 2008). The features considered can be manually set by the user (Phillips and Dudík, 2008), or automatically by the algorithm when using the "autofeatures" option. Finally, given a fixed number of predictors and features allowed in the model, Maxent controls for model complexity through the regularization parameter (a set of parameters called beta-multipliers). Maxent forces the predicted values of the variables such as mean and variance to match the values of the presence locations. Thus, the regularization parameter prevents Maxent from over-fitting assuring that the predicted values do not fit too exactly the empirical constraints of the predictor (Merow et al., 2013). Higher values of regularization parameter penalize the inclusion of parameters, thus creating less complex models than the default (regularization parameter $=1$ ). Also the $\beta$-multiplier limits the number of features included in the model based on the number of presences (with more data allowing for an increasing number of features; Merow et al., 2013). Even though Maxent-users can control model complexity by modifying default setting options (i.e. model specifications; Phillips et al., 2006), in most studies using Maxent, model complexity is completely ignored (Muscarella et al., 2014; Warren et al., 2014; Yackulic et al., 2013).

Here, we study the effect of model complexity on the ability of Maxent models to predict species distributions across time. Specifically, we fit models with current presence data for Alnus glutinosa (L.) Gaertn. and Corylus avellana L. and different levels of complexity, and compare their performance when predicting both present and mid-Holocene distributions. Furthermore, we analyze whether the Maxent default settings are optimal to project these species under both current and past climate conditions. These two European species are ideal for evaluating model projections across time due to their wide current distribution across Europe and their strong representation in the fossil record.

\section{Materials and methods}

\subsection{Study area}

Correlative SDMs assume the equilibrium of species with climate and that the training data are illustrative of environment to which the models are predicted (Elith et al., 2010). In order to account for the full ecological range of the species (Hijmans and Elith, 2013), we fit models using available current occurrences from Europe. We used the paleorecord from continental Spain to validate the model projections to past climatic conditions. Consequently, we avoided truncating the niche estimation and reduced the likelihood of extrapolating, i.e. projecting outside the climatic conditions present in the training data (Elith et al., 2010). Following Elith et al. (2010) we checked for extrapolation, with a multivariate environmental similarity surface analysis (MESS), by comparing the current climatic conditions contained in the calibration dataset and mid-Holocene climatic conditions (Fig. C1).

\subsection{Study species}

A. glutinosa (black alder) and C. avellana (hazel) are widely distributed in the Atlantic and Centro-European Region, and have their southern geographical limits in the Mediterranean Region (Fig. 1). The distribution of A. glutinosa ranges from Ireland to western Siberia and from mid-Scandinavia to Northern Africa (Morocco and Algeria; Kajba and Gračan, 2003). Meanwhile, C. avellana populations are distributed from Ireland to the Ural Mountains in Russia and from Scandinavia to southern Spain (Castroviejo et al., 1986-2012).

Within Spain, the two species are mainly found in the northern mountainous region with some scattered populations in the southwestern part of the country (Castroviejo et al., 1986-2012). According to the pollen record, and considering the lack of midHolocene pollen records in Western and Southwestern continental Spain, the current distribution of both species in Spain is similar to that of the mid-Holocene (Fig. 1). Additionally, identification of their pollen is very reliable, as they are the only species within their respective genera present during the Holocene in the Iberian Peninsula. 



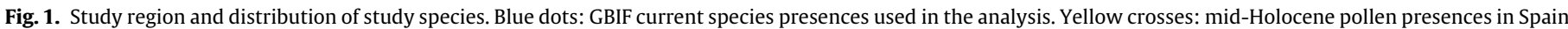
for Alnus (A) and Corylus (B) (For interpretation of the references to color in this figure legend, the reader is referred to the web version of this article.).

\subsection{Presence data}

Current occurrence data for the two species were obtained from the Global Biodiversity Information Facility database (GBIF; http:// www.gbif.org/ accessed January 2012). We excluded occurrences with a reported coordinate precision $\geq 10 \mathrm{~km}$ as well as countries not represented in GBIF or with uneven sampling effort (Mateo et al., 2013). Thus, we only included occurrences from Andorra, Belgium, Finland, France, Germany, Netherlands, Norway, Spain, Sweden and United Kingdom (Fig. 1). From the extracted $\sim 50,000$ presences per species, 10,000 records were randomly subsampled with $1 \mathrm{~km}$ minimum distance (Beck et al., 2014; Mateo et al., 2013) to reduce computing time. Non-metric multidimensional scaling (NMDS) analyses were performed with the distributions obtained from GBIF and the whole European distributions as in Atlas Florae Europaeae (Jalas and Suominen, 1972-1994) at $50 \mathrm{~km}$ for both species (Fig. D1). We discard the possibility of geographical bias in the calibration dataset leading to an environmental bias because there is an overlap in the environmental space between the GBIF data and the AFE data for both species as observed in (Figs. D1-D2).

We obtained paleorecords for the mid-Holocene in Spain (Fig. 1) from the European Pollen Database (2007-2015) (EPD; http://www.europeanpollendatabase.net), the Spanish research project Paleodiversitas (Carrión et al., 2013; Paleodiversitas, 2011, http://www.paleodiversitas.org/) and other references (Table A1 and references in Appendix A). The pollen percentages of each species were estimated relative to the total amount of terrestrial plant pollen grains (i.e. excluding wetland and aquatic species) for the $6 \pm 0.25 \mathrm{kyr} c a l$
BP interval. Pollen data obtained from the EPD or directly provided by the authors were expressed as the average of pollen percentages. We estimated percentages for the remaining pollen records from pollen diagrams. To locate the studied time period when ages in the diagrams were not expressed as calendar years, we calibrated the radiocarbon dates using the program CALIB 6.0 (Stuiver et al., 2012) coupled with the INTCAL09 calibration curve (Reimer et al., 2009), and constructed an age-depth model using linear-interpolation between consecutive 14C datings. Only pollen records with chronologies built with two or more $14 \mathrm{C}$ datings were used.

We classified pollen percentages into presence/absence using a $0.5 \%$ and $1 \%$ threshold for Alnus and Corylus, respectively (Lisitsyna et al., 2011; Szczepanek et al., 2004). For Alnus, the 0.5\% threshold provides the highest agreement between pollen and vegetation data (Lisitsyna et al., 2011). For Corylus, a 1\% threshold was recommended by Lisitsyna et al. (2011).

A total of 55 pollen sites were studied (Table A1), with 27 presences and 28 absences for Alnus and 36 presences and 19 absences for Corylus in the Iberian Peninsula (Fig. 5). Since both Alnus and Corylus are wind pollinated taxa with high pollen production (Erdtman et al., 1969), underrepresentation of species in the pollen core is rare. Hence, absences in pollen sites can be considered reliable.

\subsection{Climate data}

Current climate data for Europe were downloaded from the Worldclim database (http://www.worldclim.org/; Hijmans et al., 
Table 1

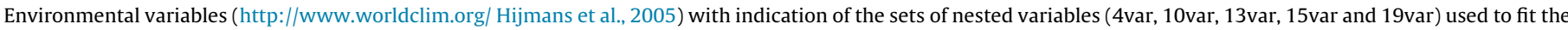
models.

\begin{tabular}{|c|c|c|c|c|c|c|}
\hline & \multirow[t]{2}{*}{ Description } & \multicolumn{5}{|c|}{ Variable set } \\
\hline & & 4var & 10var & 13 var & 15 var & $19 \mathrm{var}$ \\
\hline BIO 01 & Annual mean temperature & & & & $\mathrm{X}$ & $\mathrm{X}$ \\
\hline BIO 02 & Mean diurnal range (Mean of monthly (max temp - min temp)) & & $\mathrm{X}$ & $\mathrm{X}$ & $\mathrm{X}$ & $\mathrm{X}$ \\
\hline BIO 03 & Isothermality (BIO2/BIO7) $(\times 100)$ & & & $\mathrm{X}$ & $\mathrm{X}$ & $\mathrm{X}$ \\
\hline $\mathrm{BIO} 04$ & Temperature seasonality (standard deviation $\times 100$ ) & & & $\mathrm{X}$ & $\mathrm{X}$ & $\mathrm{X}$ \\
\hline BIO 05 & Max temperature of warmest month & & $\mathrm{X}$ & $\mathrm{X}$ & $\mathrm{X}$ & $\mathrm{X}$ \\
\hline BIO 06 & Min $\mathrm{T}^{\circ}$ coldest month & $\mathrm{X}$ & $\mathrm{X}$ & $\mathrm{X}$ & $\mathrm{X}$ & $\mathrm{X}$ \\
\hline BIO 07 & Temperature annual range (BIO5-BIO6) & & $\mathrm{X}$ & $\mathrm{X}$ & $\mathrm{X}$ & $\mathrm{X}$ \\
\hline BIO 08 & Mean temperature of wettest quarter & & & & & $\mathrm{X}$ \\
\hline BIO 09 & Mean temperature of driest quarter & & & & & $\mathrm{X}$ \\
\hline BIO 10 & Mean $\mathrm{T}^{\circ}$ warmest quarter & $\mathrm{X}$ & $\mathrm{X}$ & $\mathrm{X}$ & $\mathrm{X}$ & $\mathrm{X}$ \\
\hline BIO 11 & Mean temperature of coldest quarter & & $\mathrm{X}$ & $\mathrm{X}$ & $\mathrm{X}$ & $\mathrm{X}$ \\
\hline BIO 12 & Annual precipitation & $\mathrm{X}$ & $\mathrm{X}$ & $\mathrm{X}$ & $\mathrm{X}$ & $\mathrm{X}$ \\
\hline BIO 13 & Precipitation of wettest month & & & & & $\mathrm{X}$ \\
\hline BIO 14 & Precipitation of driest month & & & $\mathrm{X}$ & $\mathrm{X}$ & $\mathrm{X}$ \\
\hline $\mathrm{BIO} 15$ & Precipitation seasonality (Coefficient of variation) & & $\mathrm{X}$ & $\mathrm{X}$ & $\mathrm{X}$ & $\mathrm{X}$ \\
\hline BIO 16 & Precipitation of wettest quarter & & & & $\mathrm{X}$ & $\mathrm{X}$ \\
\hline BIO 17 & Precipitation driest quarter & $\mathrm{X}$ & $\mathrm{X}$ & $\mathrm{X}$ & $\mathrm{X}$ & $\mathrm{X}$ \\
\hline BIO 18 & Precipitation of warmest quarter & & $\mathrm{X}$ & $\mathrm{X}$ & $\mathrm{X}$ & $\mathrm{X}$ \\
\hline BIO 19 & Precipitation of coldest quarter & & & & & $\mathrm{X}$ \\
\hline
\end{tabular}

2005) at 30 as $\left(\sim 1 \mathrm{~km}^{2}\right)$ resolution. This database provides 19 bioclimatic variables derived from monthly temperature and precipitation data for the 1950-2000 period. These variables represent annual trends, seasonality and extremes in climate that act as limiting environmental factors for many organisms (Hijmans et al., 2005; Kumar and Stohlgren, 2009).

In order to reproduce mid-Holocene climatic conditions in the Iberian Peninsula and to determine the effect of the General Circulation Model, we used two Ocean Atmospheric General Circulation Models (OA-GCMs): the CCSM (http://www.ccsm.ucar. edu; Kiehl and Gent, 2004) and the MIROC3.2 (http://www.ccsr. u-tokyo.ac.jp/ehtml/etopindex.shtml). Monthly values of temperature and precipitation for the two OA-GCMs were compiled from the Paleoclimate Modeling Intercomparison Project Phase 2 (PMIP2) database. The variables were extracted at the original resolution $\left(2.5^{\circ}\right.$ cell sizes $)$ covering the entire Iberian Peninsula. Following the standard change-factor approach to downscale the data, we computed anomalies between mid-Holocene and current climatic conditions from the OA-GCMs output, and downscaled the anomalies to a spatial resolution of 30 as using regularized splines. To avoid potential estimations of negative values of precipitation, the anomalies for this variable were calculated as relative differences (Hijmans and Graham, 2006; Lima-Ribeiro et al., 2013). Finally, mid-Holocene climates were calculated adding the interpolated differences to the current climate (i.e. pre-industrial values) from the Worldclim database. This approach accounts for the effect of topography, ensuring consistency of the climatic patterns across time (Hijmans and Graham, 2006). Finally, the 19 bioclimatic variables were calculated from the downscaled data of past monthly temperatures and precipitations.

\subsection{Model calibration and tuning of complexity}

We ran the models with the Maxent modeling algorithm version 3.3.3k (Phillips et al., 2006). Present distribution models for both species were developed with the occurrence data and 10,000 random background points, representing the distribution of environmental conditions in the study region (Phillips and Dudík, 2008). To avoid a geographical bias in our models, we randomly chose the background points from the same European countries for which presences were used. Because we were interested in studying the variation in performance across models, we built all the models with the same occurrence and background data to avoid any potential source of variation due to differences in data input. We randomly selected $70 \%$ of the data (both presences and background) to fit the models and held the remaining 30\% for testing purposes running one replicate per model. To project the models under mid-Holocene conditions we used clamping, the default setting in Maxent in case of extrapolation, i.e. making the response constant outside of the range of the training data (Elith et al., 2010). Finally, we used the logistic output for the final geographical predictions (Phillips and Dudík, 2008).

We analyzed three potential sources of complexity: number of variables, number and type of features included in the model, and $\beta$-multipliers. To do so, we calibrated a total of 110 models for each species. First, we selected five subsets of nested predictor variables (with 4,10,13, 15 and 19; Table 1). The 4 variables set was based on ecological criteria (Pearman et al., 2008; Prentice et al., 1992) and avoiding correlated variables (Pearson $r \geq 0.75$ ), with increasing correlation allowed in the subsequent set of variables. Second, we compared two different sets of feature classes: the default "autofeatures" option (which allows all possible features), and allowing only linear, quadratic, and product (LQP) features. We used LQP all together because species responses to ecological gradients are frequently nonlinear. Quadratic responses are suitable for unimodal curves, as expected for fundamental niches (Austin, 2007), and product, i.e. interaction between variables, is not rare. Autofeatures include for LQP plus threshold and hinge features, which are useful when there is a physiological tolerance limit (Merow et al., 2013). Finally, we tested 11 different $\beta$-multipliers (from 0 to 5 in steps of 0.5 ).

The most complex model resulted from the combination of the highest number of variables (19 variables), the lowest $\beta$-multiplier $(\beta=0)$ and enabled autofeatures, whereas the simplest model arose from using the smallest number of variables (four variables), the highest $\beta$-multiplier $(\beta=5)$, and allowing only LQP features in the model.

\subsection{Model evaluation}

In order to evaluate the performance of models under current climate conditions, we used two methods. First, we calculated the AUC (Area Under the receiver operating characteristic Curve) using the testing dataset (30\% of the presences and background; Araújo et al., 2005). AUC is a threshold independent statistic that informs about the ability of a model to discriminate between presences and 

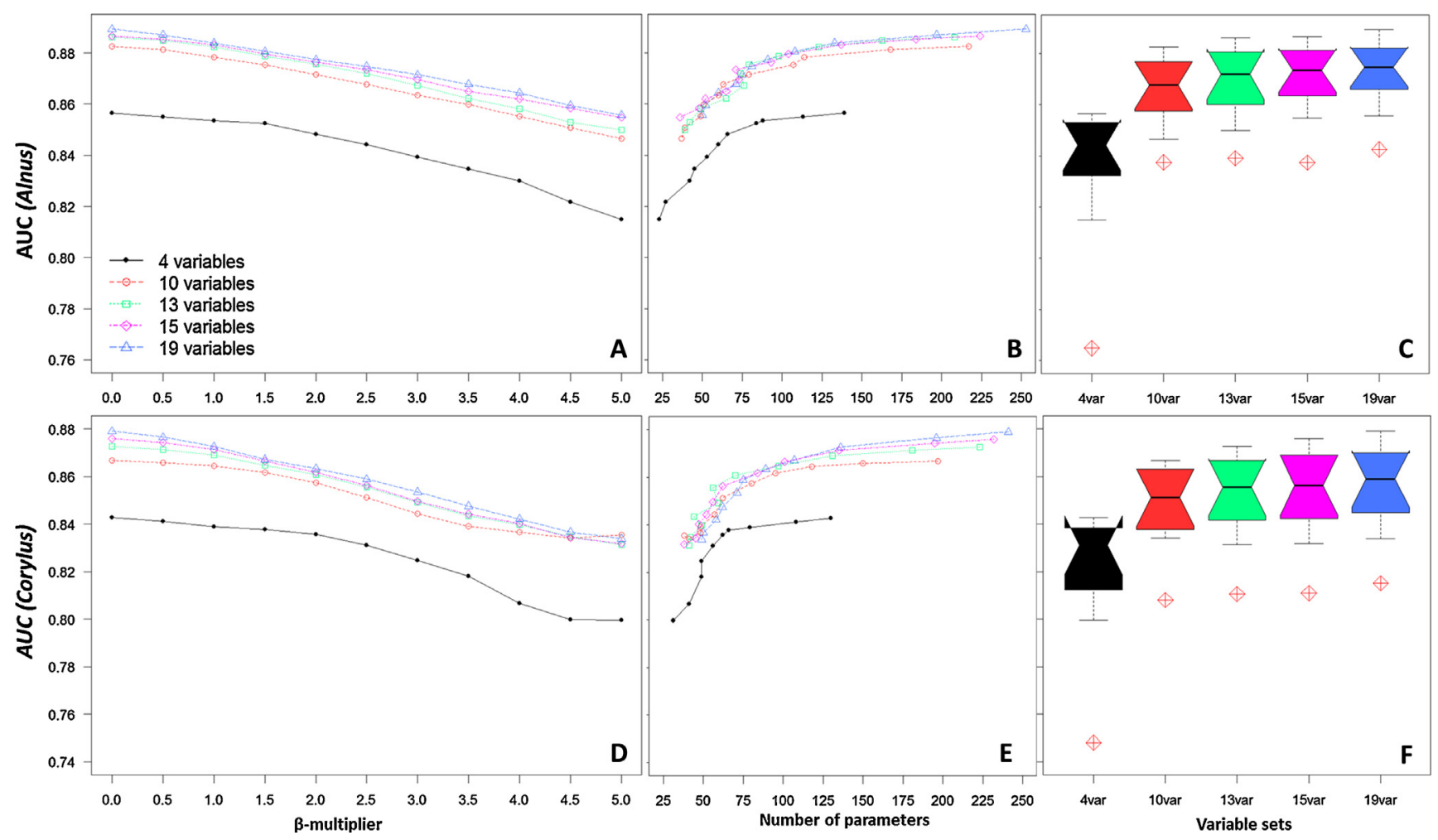

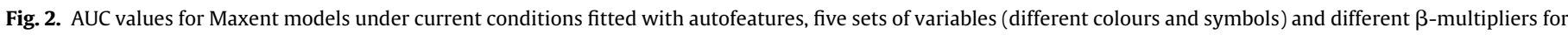

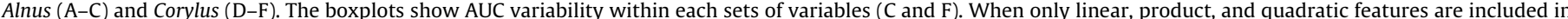

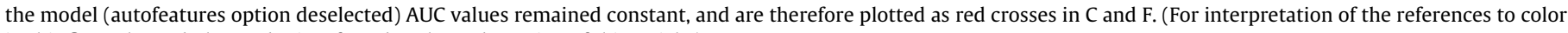
in this figure legend, the reader is referred to the web version of this article.)

absences from the study area (Fielding and Bell, 1997; Lobo et al., 2008). AUC has become the standard to assess the predictive accuracy of SDMs, allowing comparisons among different models for a single species and a single study region (Lobo et al., 2008). Second, we calculated the Akaike Information Criterion corrected for small sample sizes (AICc; Johnson and Omland, 2004) since AUC does not account for goodness-of-fit of the model, model complexity, or the increase of false absences due to the use of background data (Lobo et al., 2008; Warren and Seifert, 2011). AICc is a balanced statistic between the goodness of fit and the number of parameters of the model (Johnson and Omland, 2004), which allows selecting models with optimal complexity (Warren and Seifert, 2011). Additionally, we assessed the differences in suitability of the best current models selected according to AUC and AICc projected to geographical space.

To evaluate projections to mid-Holocene climate conditions in continental Spain, we used the fossil pollen data as independent datasets. Here, we calculated AUC, which tests the ability of the models' mid-Holocene projections to discriminate between real mid-Holocene presence and absence of the species derived from thresholded pollen data (e.g. Pearman et al., 2008). Because pollen from wind pollinated taxa can represent presences at coarser spatial scales than our analysis (Nieto-Lugilde et al., 2015), we also calculated the correlation (Spearman coefficient) between pollen percentages and the habitat suitability values predicted by the model. Pollen percentages should be less sensible to scale than presences/absences derived from pollen thresholds. This correlation also served as a sensitivity test to assess whether the percentage and threshold analyses lead to the same results, since most SDM studies using pollen data only use thresholded values (Pearman et al., 2008; Record et al., 2013) and there is no consensus in the percentage that defines the presence for each species (Lisitsyna et al., 2011). AICc was not calculated in the past because it was obtained only for the calibrated models which were the current ones.

All the analysis were conducted with the R software (packages: vegan, dismo and raster; http://cran.r-project.org/) except for the AICc analysis, which was run with the software ENMtools (Warren et al., 2010). Past climate variables were transformed with GRASS GIS software (GRASS Development Team, 2012).

\section{Results}

\subsection{Evaluation of current species distributions}

The AUC on the test dataset varied from 0.765 to 0.889 (mean \pm s.d. $=0.844 \pm 0.032$ ) for Alnus (Fig. 2A-C) and from 0.748 to $0.879(0.823 \pm 0.034)$ for Corylus (Fig. 2D-F). For both species, AUC increased with model complexity. The highest values were thus observed in the most complex models-i.e. models resulting from combining 19 variables, $\beta=0$ and autofeatures. Conversely, the lowest AUC values were obtained with the simplest model-i.e. when combining four variables, $\beta=5$, and allowing only LQP features (Fig. $2 \mathrm{C}$ and $\mathrm{F}$ ). When the number of parameters exceeded 100-125 the AUC values reached a plateau. Differences in AUC between the five variable sets were small, except for the models run with 4 variables.

Contrary to AUC, AICc values did not converge on the most complex model (Fig. 3). For both species, the best model according to AICc was the one run with autofeatures and highest number of variables (19), but differed in the optimal $\beta$-multiplier. The best model for Alnus was obtained when the $\beta$-multiplier equaled 2.5 , resulting in 81 parameters, while the default $\beta$-multiplier $(\beta=1)$ produced 133 parameters (Fig. 3A and B). The best model for Corylus was at $\beta$-multiplier equal 1.5, resulting in an intermediate number of 107 


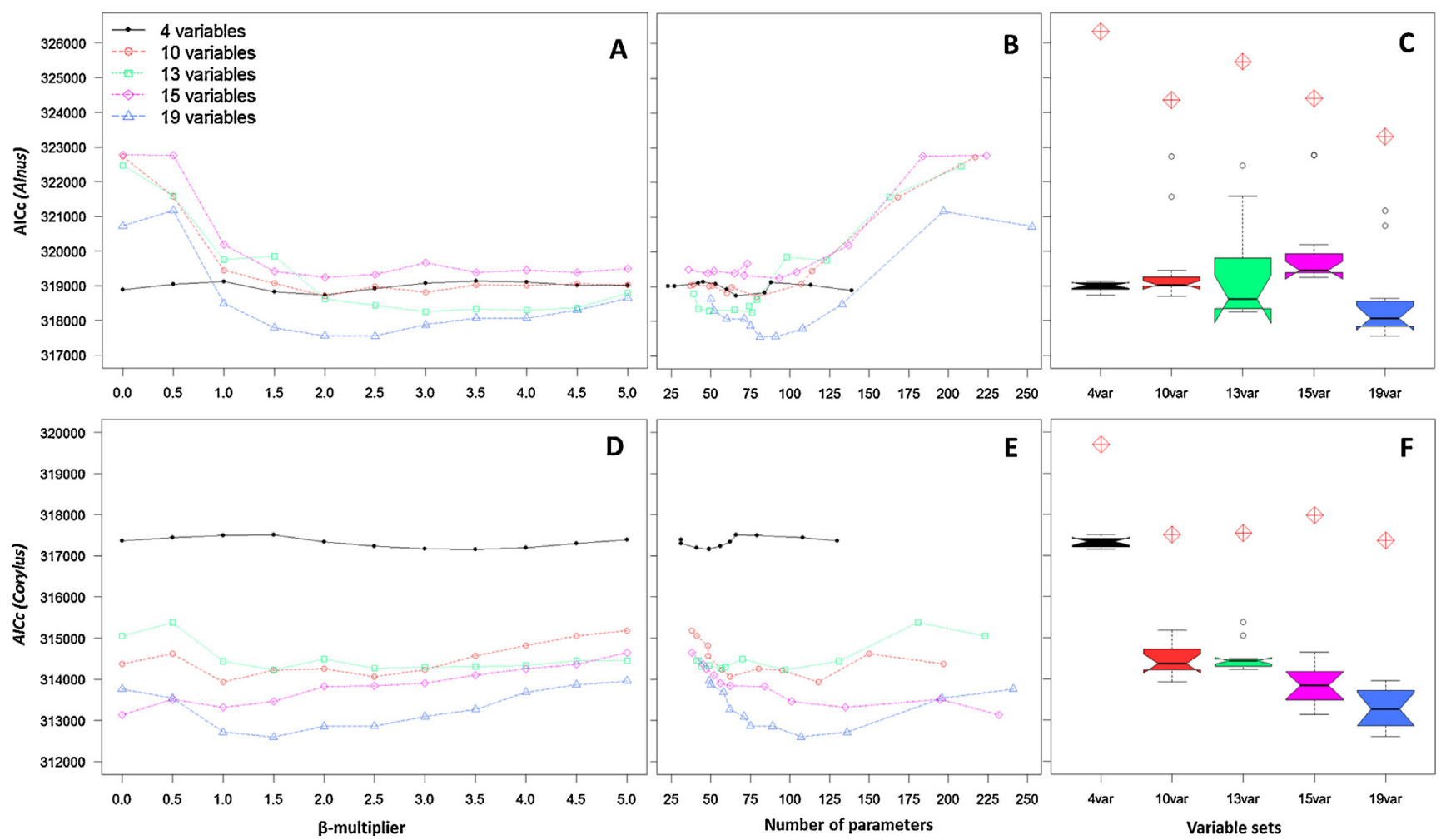

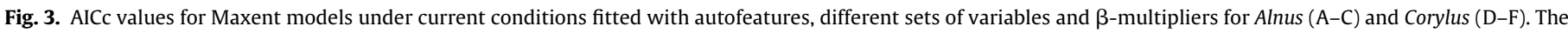

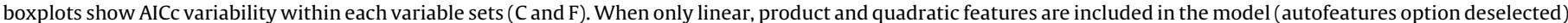

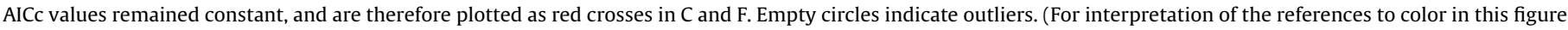
legend, the reader is referred to the web version of this article.)

parameters, whereas the default $\beta$-multiplier $(\beta=1)$ produced 136 parameters (Fig. 3D and E).

Both AUC and AICc values were constant across $\beta$-multipliers when only LQP features were allowed in the models, being only affected by the number of variables.

The projected suitable areas for the best models selected according to AUC and AICC showed similar patterns (Figs. G1 and G2). However, the models with lowest AICc tended to predict higher suitability values in each pixel than models with the highest AUC (Figs. G1, C and F).

\subsection{Evaluation of mid-Holocene projections}

The results for both species were similar under both OA-GCMs (Fig. 4 and Fig. E1 for MIROC and Figs. F1-F2 for CCSM), with no significant differences in mean AUC values (Student's $t$-test, $n=220$, $t=-1.335, p$-value $=0.183$ ) nor in the correlation values between pollen percentages and the suitability index of the models $(n=220$, $t=-0.303, p$-value $=0.762$ ). Hence, we report the results for MIROC in the rest of the manuscript, while CCSM results are reported in Appendices F1-F2 for the sake of simplicity.

AUC values for mid-Holocene projections evaluated with pollen data decreased slightly relative to the tests with current occurrences (Fig. 4). AUC varied from 0.663 to $0.808(0.741 \pm 0.035)$ for Alnus, and from 0.762 to $0.872(0.823 \pm 0.021)$ for Corylus. The highest AUC for Alnus was obtained with 19 variables, autofeatures, and $\beta$-multiplier equal to 1.5 , whereas for Corylus, it was obtained with four variables, autofeatures, and $\beta$-multiplier equal 1.5 (Fig. 5). AUC generally increased with increasing $\beta$-multipliers (Fig. 4), with the exception of models with 4 variables, which showed constant values for all $\beta$-multipliers. In the case of Alnus, all the models (except those with four variables) reached a maximum at $\beta=1.5-2.5$ and then slightly decreased, whereas for Corylus, all the models (except those with four variables) stabilized at $\beta \sim 3$.

The effect of model complexity tested against pollen percentages was similar to that described for AUC, except for the models of Corylus run with four variables (Figs. E1 and F2). Alnus models reached a maximum at $\beta=1.5-2.5$ and then decreased, whereas Corylus models stabilized at $\beta=\sim 2.5$. Similar to the evaluation with current data, the past AUC and the correlation values were the same along all the $\beta$-multipliers used when only LQP features were allowed in the models (Fig. 4B and D and Fig. E1, B and D).

\section{Discussion}

The complexity of SDMs affects both model performance and the area predicted as suitable (Warren and Seifert, 2011; Merow et al., 2014). Even when complex models show high performance predicting current distributions, they may produce poor predictions at new sites or different time periods (Warren et al., 2014). The poor transferability of complex correlative models could be a consequence of not capturing the species niche correctly by fitting the models too closely to the training data (overfitting) and preventing them from generalizing well (Warren et al., 2014). Assessing the effects of complexity in the transferability of correlative SDMs predictions is still fundamental given their broad implementation.

\subsection{Effects of complexity in current and past species distributions}

As expected, we found that complex models performed well under current conditions. The best models according to the AUC for predicting current distributions were the most complex, reflecting that AUC does not consider model complexity nor goodness-of-fit (Lobo et al., 2008; Warren and Seifert, 2011). In contrast, using the AICc and thus selecting the model by balancing 

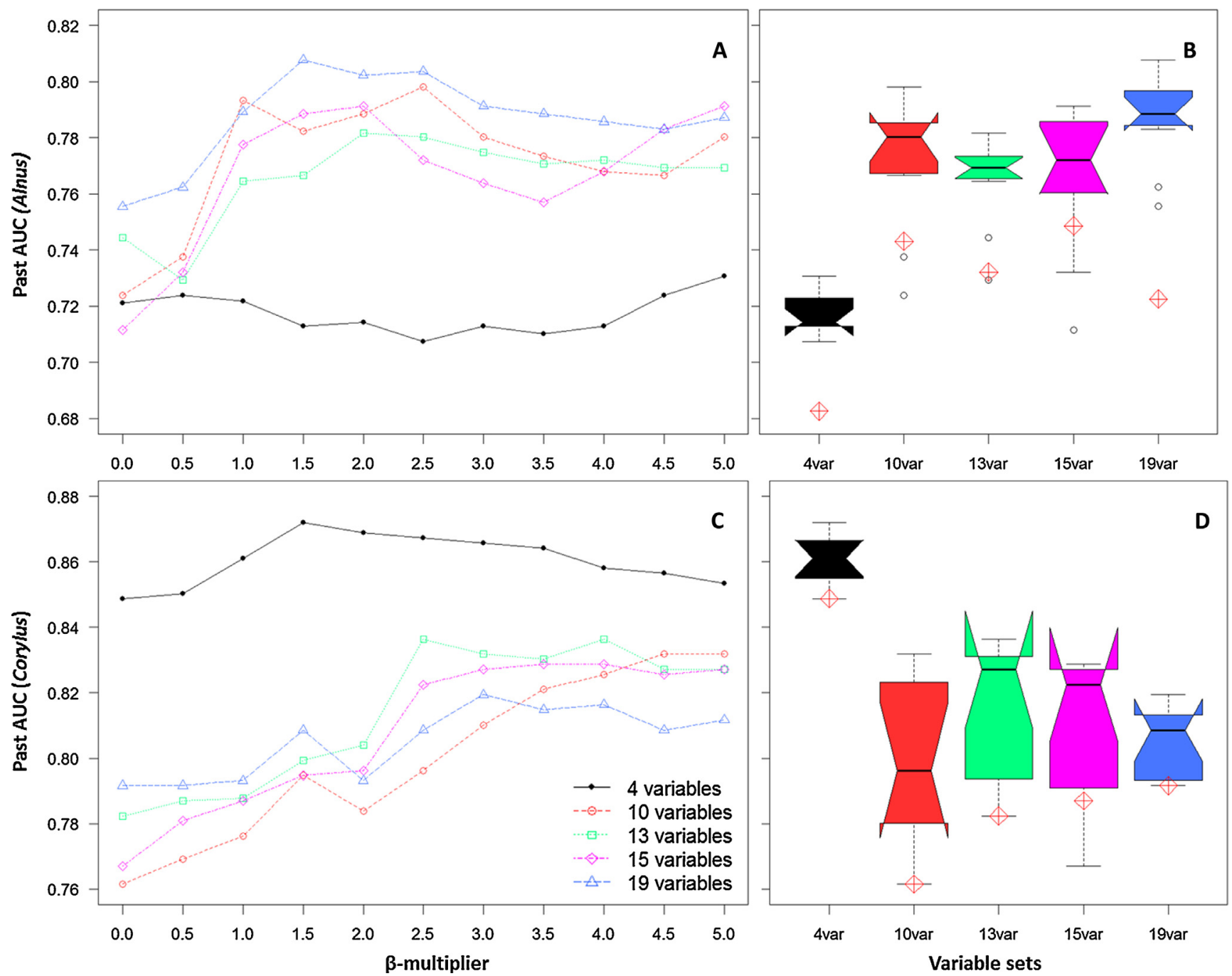

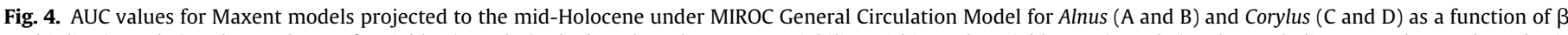

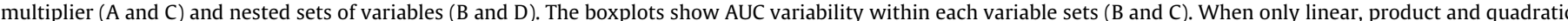

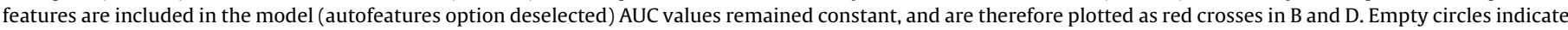
outliers. (For interpretation of the references to color in this figure legend, the reader is referred to the web version of this article.)
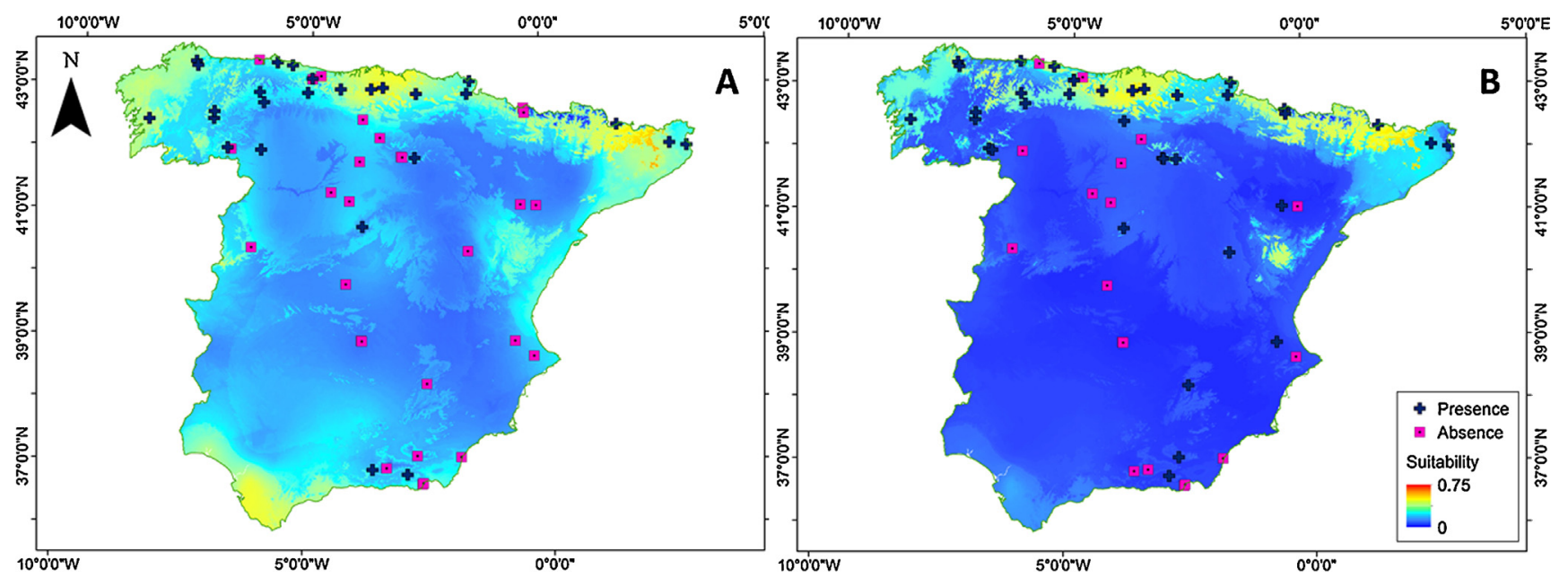

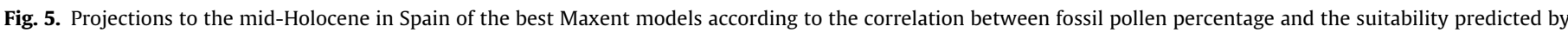

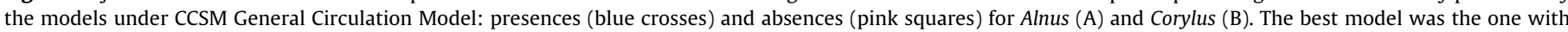

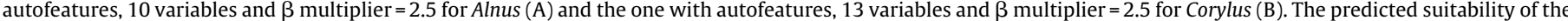

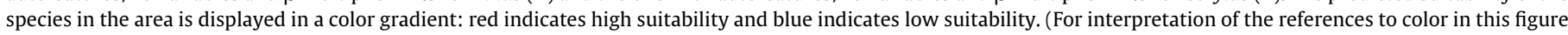
legend, the reader is referred to the web version of this article.) 
overparameterization and model fit, resulted in the selection of models with less parameters (Fig. 3), which had slightly lower AUC (Fig. 2). Furthermore, the AICc-selected models showed better cross-time transferability than AUC-selected models, with the former resulting in higher AUCs and correlation values when hindcasted. Thus, while the more complex models performed well under current conditions, they performed poorly when transferred in time to mid-Holocene climatic conditions (Fig. 4 and Figs. E1, F1 and F2).

The effects of model complexity were also apparent as geographic differences in the predicted current distribution of each species (Figs. G1-G2). For instance, the less complex AICcselected models predicted a wider potential distribution for both species than the overfitted AUC-selected models. However, these differences varied across regions (Figs. G1-G2). For example, AUCselected model predictions were narrower in the northern parts of the distribution for both species, although this trend was not as clear in the Iberian Peninsula, especially in the binary predictions (Fig. G2).

The two independent paleobotanical validations used (past AUC using pollen thresholds and correlation using pollen percentages) overall led to the same trends. Selecting a threshold to estimate local species presence from pollen percentage is complex due to the lack of agreement in the percentage that could be considered as presence for a species in a pollen core (Lisitsyna et al., 2011). However, since the percentage and threshold analyses produced similar results, the threshold selection did not introduce bias.

Our results are thus in line with Warren et al. (2014), who found that model complexity strongly impacted both the modeled niche breadth and the projected suitability under future climate scenarios. Complex models calibrated on current conditions may thus overestimate the reduction of environmental suitability under climate change. As correlative SDMs are increasingly used as a tool to identify future suitable areas for hosting species (Araújo et al., 2011) such erroneous projections can have strong consequences in conservation plans and management strategies.

\subsection{How do Maxent settings affect model complexity?}

Our results show that the factors most affecting Maxent model complexity are primarily the features classes included in the model, second the number of environmental predictors, and finally the $\beta$-multiplier selected (Fig. 3, and Table B1).

In terms of model performance, the feature types had a much larger effect than the number of variables or the $\beta$-multiplier (Figs. 2 and 4 and Figs. F1-F2). This is because forcing the model to use only LQP features heavily restricted the number of parameters allowed in the model (Table B1). In current projections, the AUCselected and AICc-selected models agreed in the use of autofeatures as well as AUC in hindcasted models. Thus, in both present and past times, autofeatures were the option with greatest predictive performance. In contrast, Syfert et al. (2013) found that the choice of feature types had relatively minor effects on model performance when compared to the correction for sampling bias, and suggested that the autofeatures may be capturing local idiosyncratic effects rather than broad physiological responses of the species. They recommended fitting simple features like linear and quadratic and use them when they present similar performance values than with the autofeatures option (Syfert et al., 2013). Furthermore, Shcheglovitova and Anderson (2013) stated that it is possible to achieve models that outperform those obtained with default settings by coupling complex features with higher regularization to ensure that the model has a low number of parameters. However, in our study the number of variables had a greater effect than the $\beta$ multiplier. Too few variables could lead to under-parameterization and thus a poor representation of the full ecological range of the species (Synes and Osborne, 2011; Syfert et al., 2013) as observed in our results of both species in the 4 variable model set.

Finally, the $\beta$-multiplier also had some influence on model performance and cross-temporal predictions. We found that the $\beta$-multiplier selected as the best compromise between performance and overprediction was higher than the default $(\beta=1)$, in accordance with former studies (Anderson and González, 2011; Muscarella et al., 2014; Radosavljevic and Anderson, 2014; Shcheglovitova and Anderson, 2013). AICc-selected models had higher $\beta$-multiplier and thus less parameters than the default $\beta$ multiplier models, which were not the models with highest AUC as also observed by Muscarella et al. (2014). Decreasing AUC of the models with higher regularization multiplier has also been demonstrated in other studies (e.g. Shcheglovitova and Anderson, 2013).

\subsection{The importance of species-specific tuning in Maxent models}

The two species studied obtained different optimal parameters for best cross-temporal transferability among them (same features, but different number of variables and beta-multipliers) but higher (regularization parameter) than default Maxent settings in both species. Therefore, our findings jointly with other studies (e.g. Cao et al., 2013; Halvorsen et al., 2015; Muscarella et al., 2014; Warren et al., 2014), highlight the importance of testing a range of parameter settings to see which perform best in each study case when using Maxent to predict the distribution of a species in different time periods.

\section{Conclusions and further recommendations}

Model complexity is a major issue that affects model performance and transferability and should be taken into account when projecting models across time. In general, Maxent users select default settings for complexity which, as we demonstrated in this study, can lead to the generation of over-complex models. In our study, complex models performed more poorly over time, indicating that standard methods for evaluating models that do not consider complexity (Fielding and Bell, 1997; Lawson et al., 2014) cannot be recommended. We highly encourage conducting species-specific tuning when modeling distributions with Maxent to determine the best modeling options, as suggested by other authors (e.g. Halvorsen et al., 2015; Muscarella et al., 2014; Shcheglovitova and Anderson, 2013). When paleoecological data are available, we recommend their use to make validations of SDMs projected in time. The use of this data allows us to understand the effects of model complexity through time and constitutes a reliable and independent dataset to test hindcasted models. Unfortunately, however, such data are scarce. When no paleoecological data are available and the aim of the study includes cross-temporal projections of species distributions, our results suggest that simpler models, with an intermediate complexity (intermediate number of variables and intermediate $\beta$-multiplier coupled with autofeatures option selected) will produce the best cross-temporal transferability.

\section{Data accessibility}

Species current distribution can be found in GBIF database: http://www.gbif.org/species

Species mid-Holocene distribution can be obtained from: European Pollen Database (http://www.europeanpollendatabase.net/ fpd-epd) and references uploaded as online supporting data.

Climate data: http://www.worldclim.org/download. 


\section{Acknowledgments}

EMA was supported by a Technical University of Madrid (Spain) grant (UPM-RR01/2011) and a visiting grant from Graduate School Science and Technology (Aarhus University, Denmark). This research was funded by the project CGL2011-27229 (DINECOFOR) from the Spanish Ministry of Economy and Competitiveness, and CLIMIFORAD from the Inter-American Development Bank (RG-T1837). RGM was funded by a Marie Curie Intra-European Fellowship within the 7th European Community Framework Programme (ACONITE, PIEF-GA-2013-622620). DNL was supported by Universidad de Granada (Spain) throughout a Perfeccionamiento de doctores Fellowship. NMH acknowledges support from the Aarhus University Research Foundation. JCS was supported by the European Research Council (ERC-2012-StG-310886-HISTFUNC). The authors are especially grateful to César Morales del Molino, Lourdes López Merino, Maria Fernanda Sánchez Goñi, José Antonio López Sáez, Francesc Burjachs Casas, Miriam Dorado Valiño, Tony Stevenson and Penélope González Sampériz for providing the raw pollen data. We also thank the data providers of the Global Biodiversity Information Facility and European Pollen Database for making biodiversity data freely available. We are indebted to Salvia García Álvarez for compiling and harmonizing fossil data in the Iberian Peninsula. The authors declare that they have no conflict of interest.

\section{Appendix A. Supplementary data}

Supplementary data associated with this article can be found, in the online version, at http://dx.doi.org/10.1016/j.ecolmodel.2015. 05.035

\section{References}

Anderson, R.P., González Jr., I., 2011. Species-specific tuning increases robustness to sampling bias in models of species distributions: an implementation with Maxent. Ecol. Model. 222, 2796-2811, http://dx.doi.org/10.1016/j.ecolmodel.2011. 04.011

Araújo, M.B., Alagador, D., Cabeza, M., Nogués-Bravo, D., Thuiller, W., 2011. Climate change threatens European conservation areas. Ecol. Lett. 14, 484-492, http:// dx.doi.org/10.1111/j.1461-0248.2011.01610.x

Araújo, M., Pearson, R., Thuiller, W., Erhard, M., 2005. Validation of species-climate impact models under climate change. Glob. Change Biol. 11, 1504-1513, http:// dx.doi.org/10.1111/j.1365-2486.2005.01000.x

Araújo, M.B., Peterson, A.T., 2012. Uses and misuses of bioclimatic envelope modeling. Ecology 93 (7), 1527-1539.

Austin, M., 2007. Species distribution models and ecological theory: a critical assessment and some possible new approaches. Ecol. Model. 200,1-19, http://dx.doi. org/10.1016/j.ecolmodel.2006.07.005

Beck, J., Böller, M., Erhardt, A., Schwanghart, W., 2014. Spatial bias in the GBIF database and its effect on modeling species' geographic distributions. Ecol. Inform. 19, 10-15, http://dx.doi.org/10.1016/j.ecoinf.2013.11.002

Cao, Y., DeWalt, R.E., Robinson, J.L., Tweddale, T., Hinz, L., Pessino, M., 2013. Using Maxent to model the historic distributions of stonefly species in Illinois streams: the effects of regularization and threshold selections. Ecol. Model. 259, 30-39, http://dx.doi.org/10.1016/j.ecolmodel.2013.03.012

Carrión, J.S., 2013. Paleoflora ibérica: Plioceno-Cuaternario. Ministerio de Economía y Competitividad, Madrid. Universidad de Murcia y Fundación Séneca, Murcia, ISBN 978-84-615-9026-1 (Coord).

Castroviejo, S., 1986-2012. Flora ibérica 1-8, 10-15, 17-18, 21. Real Jardín Botánico, CSIC, Madrid (Coord).

Elith, J., Graham, C.H., Anderson, R.P., Dudík, M., Ferrier, S., Guisan, A., Hijmans, R.J., Huettmann, F., Leathwick, J.R., Lehmann, A., Li, J., Lohmann, L.G., Loiselle, B.A., Manion, G., Moritz, C., Nakamura, M., Nakazawa, Y., Overton, J.M., Peterson, A.T., Phillips, S.J., Richardson, K., Scachetti-pereira, R., Schapire, R.E., Soberón, J., Williams, S., Wisz, M.S., Zimmermann, N.E., 2006. Novel methods improve prediction of species' distributions from occurrence data. Ecography 29, 129-151, http://dx.doi.org/10.1111/j.2006.0906-7590.04596.x

Elith, J., Kearney, M., Phillips, S., 2010. The art of modelling range-shifting species. Methods Ecol. Evol. 1, 330-342, http://dx.doi.org/10.1111/j.2041-210X.2010. 00036.X

Elith, J., Leathwick, J.R., 2009. Species distribution models: ecological explanation and prediction across space and time. Annu. Rev. Ecol. Evol. Syst. 40, 677-697, http://dx.doi.org/10.1146/annurev.ecolsys.110308.120159

Erdtman, G., Sarjeant, W.A.S., Praglowski, J., Nilsson, S., Dunbar, A., 1969. Handbook of Palynology: Morphology, Taxonomy, Ecology: An Introduction to the Study of Pollen Grains and Spores. Munksgaard, Copenhagen, pp. 486.
European Pollen Database, 2007-2015., 〈http://www.europeanpollendatabase.net/〉 [accessed 23.01.12].

Fielding, A.H., Bell, J.F., 1997. A review of methods for the assessment of prediction errors in conservation presence/absence models. Environ. Conserv. 24, 38-49, http://dx.doi.org/10.1017/S0376892997000088

GBIF. Global Biodiversity Information Facility. URL: http://www.gbif.org [accessed 23.01.12].

Guisan, A., Zimmermann, N.E., 2000. Predictive habitat distribution models in ecology. Ecol. Model. 135, 147-186, http://dx.doi.org/10.1016/S03043800(00)00354-9

GRASS Development Team, 2012. Geographic Resources Analysis Support System (GRASS) Software. Open Source Geospatial Foundation Project. GRASS Development Team, 〈http://grass.osgeo.org [ [accessed 05.03.12].

Halvorsen, R., Mazzoni, S., Bryn, A., Bakkestuen, V., 2015. Opportunities for improved distribution modelling practice via a strict maximum likelihood interpretation of MaxEnt. Ecography 38, 172-183, http://dx.doi.org/10.1111/ ecog.00565

Harris, R.M.B., Porfirio, L.L., Hugh, S., Lee, G., Bindoff, N.L., Mackey, B., 2013. To be or not to be? Variable selection can change the projected fate of a threatened species under future climate. Ecol. Manage. Restor. 14, 230-234, http://dx.doi. org/10.1111/emr.12055

Hijmans, R.J., Cameron, S.E., Parra, J.L., Jones, P.G., Jarvis, A., 2005. Very high resolution interpolated climate surfaces for global land areas. Int. J. Climatol. 25, 1965-1978, http://dx.doi.org/10.1002/joc.1276

Hijmans, R.J., Elith, J., 2013. Species Distribution Modeling with R. R CRAN Project, 〈http://cran.r-project.org/web/packages/dismo/vignettes/sdm.pdf〉] [accessed 14.01.13]

Hijmans, R.J., Graham, C.H., 2006. The ability of climate envelope models to predict the effect of climate change on species distributions. Global Change Biol. 12, 2272-2281, http://dx.doi.org/10.1111/j.1365-2486.2006.01256.x

Jalas J., Suominen, J., (Eds) 1972-1994. Atlas Florae Europaeae: Distribution of Vascular Plants in Europe, Vol. 1-10. The Committee for Mapping the Flora of Europe and Societas Biologica Fennica Vanamo. Helsinki.

Johnson, J.B., Omland, K.S., 2004. Model selection in ecology and evolution. Trends Ecol. Evol. 19, 101-108, http://dx.doi.org/10.1016/j.tree.2003.10.013

Kajba, D., Gračan, J., 2003. Euforgen Technical Guidelines for Genetic Conservation and Use for Black Alder (Alnus glutinosa). International Plant Genetic Resources Institute, Rome, Italy, pp. 4.

Kearney, M.R. Wintle, B.A., Porter, W.P., 2010. Correlative and mechanistic models of species distribution provide congruent forecasts under climate change. Conserv. Lett. 3 (3), 203-213, http://dx.doi.org/10.1111/j.1755-263X.2010.00097.x

Kiehl, J.T., Gent, P.R., 2004. The community climate system model, version 2. J. Clim. 17, 3666-3682, http://dx.doi.org/10.1175/15200442(2004) 017<3666:TCCSMV>2.0.CO;2

Kumar, S., Stohlgren, T.J., 2009. Maxent modeling for predicting suitable habitat for threatened and endangered tree Canacomyrica monticola in New Caledonia. J. Ecol. Nat. Environ. 1, 94-98.

Lawson, C.R., Hodgson, J.A., Wilson, R.J., Richards, S.A., 2014. Prevalence, thresholds and the performance of presence-absence models. Methods Ecol. Evol. 5, 54-64, http://dx.doi.org/10.1111/2041-210X.12123

Lima-Ribeiro, M.S., Nogués-Bravo, D., Terribile, L.C., Batra, P., Diniz-Filho, J.A.F. 2013. Climate and humans set the place and time of proboscidean extinction in late quaternary of South America. Palaeogeogr. Palaeoclimatol. Palaeoecol. 392, 546-556, http://dx.doi.org/10.1016/j.palaeo.2013.10.008

Lisitsyna, O.V., Giesecke, T., Hicks, S., 2011. Exploring pollen percentage threshold values as an indication for the regional presence of major European trees. Rev. Palaeobot. Palynol. 166, 311-324, http://dx.doi.org/10.1016/j.revpalbo.2011.06. 004

Lobo,J.M., Jiménez-Valverde, A., Real, R., 2008. AUC: a misleading measure of the performance of predictive distribution models. Global Ecol. Biogeogr. 17, 145-151, http://dx.doi.org/10.1111/j.1466-8238.2007.00358.x

Mateo, R.G., Vanderpoorten, A., Muñoz, J., Laenen, B., Désamoré, A., 2013. Modeling species distributions from heterogeneous data for the biogeographic regionalization of the European bryophyte flora. PLoS ONE 8, e55648, http://dx.doi.org/ 10.1371 /journal.pone.0055648

Merow, C., Smith, M.J., Edwards, T.C., Guisan, A., McMahon, S.M., Normand, S. Thuiller, W., Wüest, R.O., Zimmermann, N.E., Elith, J., 2014. What do we gain from simplicity versus complexity in species distribution models? Ecography 37, 1267-1281, http://dx.doi.org/10.1111/ecog.00845

Merow, C., Smith, M.J., Silander, J.A., 2013. A practical guide to MaxEnt for modeling species' distributions: what it does, and why inputs and settings matter. Ecography 36, 1058-1069, http://dx.doi.org/10.1111/j.1600-0587.2013.07872.

Morin, X., Thuiller, W., 2009. Comparing niche-and process-based models to reduce prediction uncertainty in species range shifts under climate change. Ecology 90 (5), 1301-1313.

Morueta-Holme, N., Fløjgaard, C., Svenning, J.C., 2010. Climate change risks and conservation implications for a threatened small-range mammal species. PLoS ONE 5, e10360, http://dx.doi.org/10.1371/journal.pone.0010360

Muscarella, R., Galante, P.J., Soley-Guardia, M., Boria, R.A., Kass, J.M., Uriarte, M. Anderson, R.P. 2014. ENMeval: an R package for conductiong spatially independent evaluations and estimating optimal model complexity for Maxent ecological niche models. Methods Ecol. Evol., http://dx.doi.org/10.1111/2041 210X.12261

Nieto-Lugilde, D., Maguire, K.C., Blois, J.L., Williams, J.W., Fitzpatrick, M.C., 2015 Close agreement between pollen-based and forest inventory-based models 
of vegetation turnover. Global Ecol. Biogeogr., http://dx.doi.org/10.1111/geb. 12300

Paleodiversitas, 2011. Sistema de información sobre Paleoflora y Paleovegetación de la Península ibérica, 〈http://www.paleodiversitas.org/〉 [accessed 23.01.12].

Pearman, P.B., Randin, C.F., Broennimann, O., Vittoz, P., van der Knaap, W.O., Engler, R., Le Lay, G., Zimmermann, N.E., Guisan, A., 2008. Prediction of plant species distributions across six millennia. Ecol. Lett. 11, 357-369, http://dx.doi.org/10. 1111/j.1461-0248.2007.01150.x

Pearson, R.G., Raxworthy, C.J., Nakamura, M., Townsend Peterson, A., 2007. Predicting species distributions from small numbers of occurrence records: a test case using cryptic geckos in Madagascar. J. Biogeogr. 34, 102-117, http://dx.doi.org/ 10.1111/j.1365-2699.2006.01594.x

Phillips, S.J., Anderson, R.P., Schapire, R.E., 2006. Maximum entropy modeling of species geographic distributions. Ecol. Model. 190, 231-259, http://dx.doi.org/ 10.1016/j.ecolmodel.2005.03.026

Phillips, S.J., Dudík, M., 2008. Modeling of species distributions with Maxent: new extensions and a comprehensive evaluation. Ecography 31, 161-175, http://dx. doi.org/10.1111/j.0906-7590.2008.5203.x

Prentice, I.C., Cramer, W., Harrison, S.P., Leemans, R., Monserud, R.A., Solomon, A.M., 1992. A global biome model based on plant physiology and dominance, soil properties and climate. J. Biogeogr. 19, 117-134, http://dx.doi.org/10.2307/2845499

Radosavljevic, A., Anderson, R.P., 2014. Making better Maxent models of species distributions: complexity, overfitting and evaluation. J. Biogeogr. 41, 629-643, http://dx.doi.org/10.1111/jbi.12227

Record, S., Fitzpatrick, M.C., Finley, A.O., Veloz, S., Ellison, A.M., 2013. Should species distribution models account for spatial autocorrelation? A test of model projections across eight millennia of climate change. Global Ecol. Biogeogr. 22, 760-771, http://dx.doi.org/10.1111/geb.12017

Reimer, P.J., Baillie, M.G.L., Bard, E., Bayliss, A., Beck, J.W., Blackwell, P.G., Bronk Ramsey, C., Buck, C.E., Burr, G.S., Edwards, R.L., Friedrich, M., Grootes, P.M., Guilderson, T.P., Hajdas, I., Heaton, T.J., Hogg, A.G., Hughen, K.A., Kaiser, K.F., Kromer, B., McCormac, F.G., Manning, S.W., Reimer, R.W., Richards, D.A., Southon, J.R., Talamo, S., Turney, C.S.M., van der Plicht, J., Weyhenmeyer, E., 2009 IntCal09 and Marine09 radiocarbon age calibration curves, 0-50,000 years cal BP. Radiocarbon 51, 1111-1150.

Renner, I.W., Warton, D.I., 2013. Equivalence of MAXENT and Poisson point process models for species distribution modeling in ecology. Biometrics 69, 274-281, http://dx.doi.org/10.1111/j.1541-0420.2012.01824.x
Shcheglovitova, M., Anderson, R.P., 2013. Estimating optimal complexity for ecological niche models: a jackknife approach for species with small sample sizes. Ecol. Model. 269, 9-17, http://dx.doi.org/10.1016/j.ecolmodel.2013.08. 011

Stuiver, M., Reimer, P.J., Reimer, R., 2012. Calib 6.0, 〈http://radiocarbon.pa. qub.ac.uk/calib/calib.html [accessed 23.01.12].

Svenning, J.C., Fløjgaard, C., Marske, K.A., Nogués-Bravo, D., Normand, S., 2011. Applications of species distribution modeling to paleobiology. Quat. Sci. Rev. 30 2930-2947, http://dx.doi.org/10.1016/j.quascirev.2011.06.012

Syfert, M.M., Smith, M.J., Coomes, D.A., 2013. The effects of sampling bias and model complexity on the predictive performance of MaxEnt species distribution models. PLoS ONE 8, e55158, http://dx.doi.org/10.1371/journal. pone.0055158

Synes, N.W. Osborne, P.E., 2011. Choice of predictor variables as a source of uncertainty in continental-scale species distribution modelling under climate change. Global Ecol. Biogeogr. 20, 904-914, http://dx.doi.org/10.1111/j.14668238.2010.00635.x

Szczepanek, K., Tobolski, K. Nalepka, D, 2004. Alnus Mill. Alder In: RalskaJasiewiczowa, M., Latałowa, M., Wasylikowa, K., Tobolski, K., Madeyska, E., Wright Jr., H.E., Turner, C. (Eds.), Late Glacial and Holocene History of Vegetation in Poland Based on Isopollen Maps. W. Szafer Institute of Botany, Polish Academy of Sciences, Kraków, pp. 47-55.

Warren, D.L., Glor, R.E., Turelli, M., 2010. ENMTools: a toolbox for comparative studies of environmental niche models. Ecography 1, 607-611, http://dx.doi.org/10. 1111/j.1600-0587.2009.06142.x

Warren, D.L., Seifert, S.N., 2011. Ecological niche modeling in Maxent: the importance of model complexity and the performance of model selection criteria. Ecol. Appl. 21, 335-342, http://dx.doi.org/10.1890/10-1171.1

Warren, D.L., Wright, A.N., Seifert, S.N., Shaffer, H.B., 2014. Incorporating model complexity and spatial sampling bias into ecological niche models of climate change risks faced by 90 California vertebrate species of concern. Divers. Distrib. 20 334-343, http://dx.doi.org/10.1111/ddi.12160

Yackulic, C.B., Chandler, R., Zipkin, E.F., Royle, J.A., Nichols, J.D., Campbell Grant E.H., Veran, S., 2013. Presence-only modelling using MAXENT: when can we trust the inferences? Methods Ecol. Evol. 4, 236-243, http://dx.doi.org/10.1111/ 2041210x.12004. 